\title{
The Neotropical whale catfishes (Siluriformes: Cetopsidae: Cetopsinae), a revisionary study
}

\author{
Richard P. Vari*, Carl J. Ferraris Jr.** and Mário C. C. de Pinna***
}

The catfishes of the subfamily Cetopsinae of the Neotropical family Cetopsidae are revised. Four genera, Cetopsidium new genus, Cetopsis, Denticetopsis, and Paracetopsis Bleeker are recognized as valid. Bathycetopsis, Hemicetopsis, and Pseudocetopsis are considered synonyms of Cetopsis and Paracetopsis Eigenmann \& Bean and Cetopsogiton synonyms of Paracetopsis. Thirty-seven species are recognized in the Cetopsinae. Cetopsidium includes six species: C. ferreirai, new species, rio Trombetas; C. minutum, Essequibo River; C. morenoi, central and western portions of río Orinoco; C. orientale, coastal rivers of Suriname and French Guiana, and tentatively rio Tocantins and rio Xingu; C. pemon, new species, río Caura, río Caroni, río Meta, and rio Branco; and C. roae, new species, Rupununi River. Cetopsis includes 21 species: C. amphiloxa, río San Juan, río Atrato, and río Patia, western Colombia, and rivers of northwestern Ecuador; C. arcana, new species, rio Tocantins; C. baudoensis, río Baudo; C. caiapo, new species, rio Tocantins; C. candiru, Amazon basin; C. fimbriata, new species, río Truando; C. coecutiens, rio Amazonas, rio Tocantins, and río Orinoco; C. gobioides, upper rio São Francisco, rio Paraná, río Uruguay, and rio Juquiá; C. jurubidae, río Jurubidá; C. montana, new species, western portions of Amazon basin; C. motatanensis, Lago Maracaibo basin; C. oliveirai, Amazon basin; C. orinoco, río Orinoco, río Aroa, and río Yaracuy; $C$. othonops, río Magdalena and río Sinú; C. parma, western Amazon basin; C. pearsoni, new species, upper portions of rio Madeira; C. plumbea, western portions of rio Amazonas; C. sandrae, new species, rio Tapajós; C. sarcodes, new species, rio Tocantins; C. starnesi, new species, northwestern río de La Plata and southern rio Madeira; and C. umbrosa, new species, western río Orinoco. Cetopsis chalmersi is a synonym of C. gobioides. Cetopsis macroteronema is a synonym of C. plumbea. Denticetopsis includes seven species: $D$. epa, new species, rio Tocantins; $D$. iwokrama, new species, Siparuni River; $D$. macilenta, Potaro River; D. praecox, río Baria; D. royeroi, upper río Negro; D. sauli, upper río Negro; and $D$. seducta, new species, western portions of rio Amazonas and río Orinoco. Paracetopsis consists of three species: P. atahualpa, new species, río Tumbes, northwestern Peru, and río Zarumilla, southwestern Ecuador; P. bleekeri, río Guayas and río Santa Rosa, southwestern Ecuador; and P. esmeraldas, new species, rivers of northwestern Ecuador. Cetopsis ventralis and C. occidentalis are synonyms of Paracetopsis bleekeri. A neotype is designated for Paracetopsis bleekeri. Lectotypes are designated for Cetopsis candiru, Cetopsis chalmersi, and Cetopsis plumbeus.

Os bagres da subfamília Cetopsinae, da família neotropical Cetopsidae, são revisados. Quatro gêneros, Cetopsidium novo gênero, Cetopsis, Denticetopsis, e Paracetopsis Bleeker são reconhecidos como válidos. Bathycetopsis, Hemicetopsis, e Pseudocetopsis são considerados sinônimos de Cetopsis, enquanto que Paracetopsis Eigenmann \& Bean e Cetopsogiton sinônimos de Paracetopsis. Trinta e sete espécies são reconhecidas em Cetopsinae. Cetopsidium inclui seis espécies: $C$. ferreirai, nova espécie, rio Trombetas; C. minutum, rio Essequibo; C. morenoi, partes central e ocidental do río Orinoco; $C$. orientale, rios costeiros do Suriname e Guiana Francesa, e tentativamente rio Tocantins e rio Xingu; C. pemon, nova espécie, río Caura, río Caroni, río Meta, e rio Branco; e C. roae, nova espécie, rio Rupununi. Cetopsis inclui 21 espécies: C. amphiloxa, río San Juan, río Atrato, e río Patia, Colombia ocidental, e rios do noroeste do Equador; C. arcana, nova espécie, rio Tocantins; C. baudoensis, río Baudo; C. caiapo, nova espécie, rio Tocantins; C. candiru, bacia Amazônica; C. fimbriata, nova espécie, río Truando; C. coecutiens, rio Amazonas, rio Tocantins, e río Orinoco; C. gobioides, alto rio São Francisco, rio Paraná, río Uruguay, e rio Juquiá; $C$. jurubidae, río Jurubidá; $C$. montana, nova espécie, região ocidental da bacia Amazônica; $C$. motatanensis, bacia do Lago Maracaibo; C. oliveirai, bacia Amazônica; C. orinoco, río Orinoco, río Aroa, e río Yaracuy; $C$. othonops, río Magdalena e río Sinú; C. parma, bacia Amazônica ocidental; $C$. pearsoni, nova espécie, alto rio Madeira; $C$.

\footnotetext{
*Department of Zoology, Division of Fishes, Smithsonian Institution, PO Box 37012, National Museum of Natural History, WG-14, MRC 159, Washington, DC 20013-7012. e-mail: varir@si.edu

**Research Associate, Department of Zoology, Division of Fishes, Smithsonian Institution, PO Box 37012, National Museum of Natural History, WG-14, MRC 159, Washington, DC 20013-7012. e-mail: carlferraris@comcast.net

***Museu de Zoologia da Universidade de São Paulo, Caixa Postal 42694, São Paulo, SP, 04299-970, Brazil. e-mail: pinna@ib.usp.br
} 
plumbea, porção ocidental do rio Amazonas; C. sandrae, nova espécie, rio Tapajós; C. sarcodes, nova espécie, rio Tocantins; C. starnesi, nova espécie, noroeste do río de La Plata e sul do rio Madeira; e C. umbrosa, nova espécie, río Orinoco ocidental. Cetopsis chalmersi é sinônimo de C. gobioides. Cetopsis macroteronema é sinônimo de C. plumbea. Denticetopsis inclui sete espécies: $D$. epa, nova espécie, rio Tocantins; $D$. iwokrama, nova espécie, rio Siparuni; $D$. macilenta, rio Potaro; $D$. praecox, río Baria; D. royeroi, alto río Negro; $D$. sauli, alto río Negro; e $D$. seducta, nova espécie, porção ocidental do rio Amazonas e río Orinoco. Paracetopsis compreende três espécies: P. atahualpa, nova espécie, río Tumbes, noroeste do Peru, e río Zarumilla, sudoeste do Equador; P. bleekeri, río Guayas e río Santa Rosa, sudoeste do Equador; e P. esmeraldas, nova espécie, rios do noroeste do Equador. Cetopsis ventralis e C. occidentalis são sinônimos de Paracetopsis bleekeri. Um neótipo é designado para Paracetopsis bleekeri Bleeker. Lectótipos são designados para Cetopsis candiru, Cetopsis chalmersi e Cetopsis plumbeus.

Key words: Paracetopsis, Cetopsis, Denticetopsis, Cetopsidium, new species, South America.

\section{Introduction}

Catfishes of the subfamily Cetopsinae are among the more distinctive groups within the order Siluriformes, not only across their range in South America but among catfishes World-wide. The robust body and smoothly curved head and body profiles of the first formally described species that were assigned to the Cetopsinae were reminiscent of those features in some cetaceans and were the basis for their scientific name (from the Greek: ketos = whale, opsis = like) and, thus, the English common name of "whale catfishes." Many species of the Cetopsinae are characterized by reduced eyes that are obscured by an often thick, overlying integumentary layer, a combination of features resulting in their common names of "bagre ciego" (blind catfishes) or "ciego" (blind) in some portions of South America (Mago-Leccia, 1970: 82; Barriga, 1991: 56; 1994b: 77). In actuality, the visual acuity, or lack thereof, of members of the Cetopsinae remains undetermined, and eyes are absent in only one species in the subfamily.

Cetopsis candiru and C. coecutiens, which achieve the largest body sizes within the Cetopsinae, are notorious for their voracious feeding habits; attacking not only carrion, but also live fishes in gill-nets (Barthem \& Goulding, 1997: 44), and on occasion humans (Goulding, 1989: 185). The predatory and scavenging feeding habits of these species of Cetopsis perhaps contributed to the erroneous assumption that members of the Cetopsinae are "parasitic"; a conclusion that may have lead various previous researchers to align members of that subfamily with the species of the family Trichomycteridae, some members of which feed on the blood of their hosts. The vernacular names of "candiru-açu" for various species of the Cetopsinae in the Brazilian Amazon (Goulding, 1980: 31) and "canero" in the Peruvian Amazon (Ortega \& Vari, 1986: 15), similarly reflect the perceptions among local human populations of an alignment between the Cetopsinae and the parasitic members of the Trichomycteridae that are commonly referred to as "candirus" in Brazil and "caneros" in Peru.

In contrast to the voracious feeding habits of Cetopsis candiru and C. coecutiens, all other members of the subfamily for which the diet is known prey primarily on allochthonous and aquatic insects (Baskin et al., 1980: 184; Saul, 1975: 117;
Lundberg \& Rapp Py-Daniel, 1994: 387; Ferraris \& Brown, 1991: 164; this study). Above and beyond these dietary differences between the Cetopsinae and the Trichomycteridae, the morphological evidence demonstrates that the Cetopsinae are actually the sister group of the Helogeninae (de Pinna \& Vari, 1995: 4), a subfamily whose members also feed on allochthonous insects (Vari \& Ortega, 1986: 15). The Cetopsinae plus Helogeninae together form the Cetopsidae that recent phylogenetic studies have demonstrated occupies a position close to the base of the phylogeny of the Siluriformes (de Pinna, 1998: 292, fig. 1). The Trichomycteridae, in contrast, are a component of the superfamily Loricarioidea along with the Loricariidae, Astroblepidae, Scoloplacidae, Callichthyidae, and Nematogenyidae (de Pinna, 1998: 297, figs. 1, 6).

The Cetopsinae have a relatively broad latitudinal distribution extending from northern Colombia to central Argentina and components of the subfamily also occur in river systems to both sides of the Andean Cordilleras. In Trans-Andean South America, species of the Cetopsinae occur along the Pacific Ocean versant of the continent from the río Tumbes of northwestern Peru north to the río Jurubidá of Colombia. Along the Caribbean Sea versant of that region members of the subfamily occur from the río Sinú of northwestern Colombia to the Lago Maracaibo basin of northwestern Venezuela. East of the Andean Cordilleras members of the Cetopsinae occur in the río Aroa and río Yaracuy basins of the Caribbean Sea versant of northern Venezuela, across the río Orinoco system and the coastal rivers of the Guianas, and south through the breadth of the Amazon basin and into portions of the río de la Plata system. Along the eastern portions of South America, species of the Cetopsinae occur in the rio Juquiá basin of the state of São Paulo and in the rio São Francisco system, but with the possible exception of the rio Gurupi of northeastern Brazil are unknown from the numerous remaining, independent basins draining into the Atlantic Ocean in the broad expanse between the mouth of the rio Amazonas and the lower portions of the rio Paraná.

Species-level questions within the Cetopsinae were recently partially addressed in two unpublished studies (Oliveira, 1988; Milani de Arnal, 1991). Oliveira (1988) based his revision of the subfamily (the family Cetopsidae of that 
study) primarily on samples from Brazilian locations. Milani de Arnal (1991) supplemented her description of the osteology of Cetopsis coecutiens with comments on those members of the Cetopsinae known to inhabit the various river systems of Venezuela. Subsequent analyses of more extensive population samples of the Cetopsinae from across South America resulted in the description of a number of previously undescribed species of the subfamily (Ferraris \& Brown, 1991; Lundberg \& Rapp Py-Daniel, 1994; Ferraris, 1996; Oliveira et al., 2001; Vari et al., 2003). Additional sampling efforts through the range of the subfamily also yielded both larger samples of a number of previously described, but often poorly known, species along with populations samples of a series of previ- ously unknown species (Table 1). This additional comparative material highlighted the inadequacies of both the previously-utilized generic limits and of the purported diagnostic characters within the Cetopsinae. Examination of these additional population samples also raised questions about the reported geographic distributions for many previously described species. Unraveling these intertwined questions necessitated both an in-depth species-level analysis of the Cetopsinae across its geographic range and an intrafamilial phylogenetic analysis of the Cetopsidae. This study, focuses on the first of those questions, that of the recognizable species within the Cetopsinae and their geographic distribution. The phylogenetic analysis is the subject of a future publication.

Table 1. Nominal species assigned to the subfamily Cetopsinae in this study and the recognized equivalent species according to the results of this analysis. Nominal species are cited as in the original description and are arranged alphabetically by specific or subspecific epithet.

\begin{tabular}{|c|c|}
\hline Nominal species & Assignment herein \\
\hline Hemicetopsis amphiloxus Eigenmann, 1914 & Cetopsis amphiloxa \\
\hline Cetopsis arcana, new species & Cetopsis arcana \\
\hline Paracetopsis atahualpa, new species & Paracetopsis atahualpa \\
\hline Pseudocetopsis baudoênsis Dahl, 1960 & Cetopsis baudoensis \\
\hline Paracetopsis bleekeri Bleeker, 1862 & Paracetopsis bleekeri \\
\hline Cetopsis caiapo, new species & Cetopsis caiapo \\
\hline Cetopsis candiru Spix \& Agassiz, 1829 & Cetopsis candiru \\
\hline Cetopsis chalmersi Norman, 1926 & Cetopsis gobioides \\
\hline Silurus coecutiens Lichtenstein, 1819 & Cetopsis coecutiens \\
\hline Denticetopsis epa, new species & Denticetopsis epa \\
\hline Paracetopsis esmeraldas, new species & Paracetopsis esmeraldas \\
\hline Cetopsidium ferreirai, new species & Cetopsidium ferreirai \\
\hline Cetopsis fimbriata, new species & Cetopsis fimbriata \\
\hline Cetopsis gobioides Kner, 1857 & Cetopsis gobioides \\
\hline Denticetopsis iwokrama, new species & Denticetopsis iwokrama \\
\hline Pseudocetopsis jurubidae Fowler, 1944 & Cetopsis jurubidae \\
\hline Hemicetopsis macilentus Eigenmann, 1912 & Denticetopsis macilenta \\
\hline Cetopsis macroteronema Boulenger, 1898 & Cetopsis plumbea \\
\hline Hemicetopsis minutus Eigenmann, 1912 & Cetopsidium minutum \\
\hline Cetopsis montana, new species & Cetopsis montana \\
\hline Hemicetopsis morenoi Fernández-Yépez, 1972 & Cetopsidium morenoi \\
\hline Pseudocetopsis plumbeus motatanensis Schultz, 1944 & Cetopsis motatanensis \\
\hline Cetopsis occidentalis Steindachner, 1880 & Paracetopsis bleekeri \\
\hline Bathycetopsis oliveirai Lundberg \& Rapp Py-Daniel, 1994 & Cetopsis oliveirai \\
\hline Pseudocetopsis orientale Vari, Ferraris \& Keith, 2003 & Cetopsidium orientale \\
\hline Pseudocetopsis plumbeus orinoco Schultz, 1944 & Cetopsis orinoco \\
\hline Hemicetopsis othonops Eigenmann, 1912 & Cetopsis othonops \\
\hline Cetopsis parma Oliveira, Vari \& Ferraris, 2001 & Cetopsis parma \\
\hline Cetopsis pearsoni, new species & Cetopsis pearsoni \\
\hline Cetopsidium pemon, new species & Cetopsidium pemon \\
\hline Cetopsis plumbeus Steindachner, 1882 & Cetopsis plumbea \\
\hline Pseudocetopsis praecox Ferraris \& Brown, 1991 & Denticetopsis praecox \\
\hline Cetopsidium roae, new species & Cetopsidium roae \\
\hline Denticetopsis royeroi Ferraris, 1996 & Denticetopsis royeroi \\
\hline Cetopsis sandrae, new species & Cetopsis sandrae \\
\hline Cetopsis sarcodes, new species & Cetopsis sarcodes \\
\hline Denticetopsis sauli Ferraris, 1996 & Denticetopsis sauli \\
\hline Denticetopsis seducta, new species & Denticetopsis seducta \\
\hline Cetopsis starnesi, new species & Cetopsis starnesi \\
\hline Cetopsis umbrosa, new species & Cetopsis umbrosa \\
\hline Cetopsis ventralis Gill, 1870 & Paracetopsis bleekeri \\
\hline
\end{tabular}




\section{Methods and Materials}

Standard length is abbreviated as SL, total length as TL, and head length as HL. Measurements were taken with dial calipers, typically to $1.0 \mathrm{~mm}$, and are straight line distances between points. HL was measured from the tip of the snout to the end of the fleshy gill cover. Interorbital width was taken as the shortest distance between the orbits. This distance is difficult to measure unambiguously, particularly in larger specimens of some species, as a result of the combination of the relatively small size of the eye and the soft integumentary tissue surrounding, overlying, and thereby obscuring the orbit. The relatively soft and fleshy heads and bodies of most species in the Cetopsinae make it difficult to accurately measure most of the morphometric parameters typically reported in descriptions for many other groups of catfishes. As a consequence we do not provide these values in the species accounts of this study.

Counts of unpaired fin rays were taken from radiographs and include all fin elements, some of which are variably difficult to discern in entire specimens. Data for fin-ray counts are provided in the Diagnoses and Keys in terms of ranges and are supplemented in various tables which document the frequency of occurrence of a particular fin-ray count for each species. Vertebral counts were taken from radiographs and include the four elements of the Weberian complex and one element for the ural complex. These counts are presented in terms of preanal, precaudal, and caudal elements in the tables, with total vertebrae the sum of the precaudal and caudal vertebrae.

The bold values in Tables 2 to 29 indicate meristic values in the primary types of each species (holotypes and lectotypes) in instances when such specimens were examined. Data are arranged in a set of tables for the members of each genus of the Cetopsinae in order to facilitate intrageneric comparisons.

Descriptions of the patterns of tooth distribution and of the form of the oral and vomerine dentition are based on cleared and stained specimens when such preparations were available for a species or are otherwise based on the examination of whole specimens. Palatal dentition is limited to the vomer across all examined cleared and stained specimens of the Cetopsinae and such teeth are therefore referred to as vomerine teeth throughout the text.

Species-level diagnoses for the genera Cetopsidium, Denticetopsis, and Paracetopsis serve to discriminate each species from all of its congeners individually. Although such detailed diagnoses would be preferable for all genera, they would prove unwieldy for the overwhelming majority of the 21 species of Cetopsis. We instead provide a general diagnosis that serves to separate each species of Cetopsis from its congeners. The species of Cetopsis can be further distinguished from each other by the characters in the two keys to the species of the Cetopsinae that occur to each side of the Andean Cordilleras.

Photographed specimens are indicated as mature males when they demonstrate distal filaments on the first rays of the pectoral and dorsal fins and have a convex margin to the anal fin. Specimens that lack such modifications are assumed to be females or immature males.

The following abbreviations for institutions and collections are used: AMNH, American Museum of Natural History, New York; ANSP, Academy of Natural Sciences of Philadelphia; AUM, Auburn University Museum; BMNH, The Natural History Museum, London, formerly, British Museum (Natural History); CAS, California Academy of Sciences, San Francisco; CBF, Collección Boliviana de Fauna, La Paz; CASSU, Stanford University collections, now at CAS; DU, Duke University Fish Collection, Durham; FMNH, Field Museum of Natural History, Chicago; ICN-MHN, Instituto de Ciencias Natural, Museo de Historia Natural, Bogotá; INHS, Illinois Natural History Survey, Champaign; INPA, Instituto Nacional de Pesquisas da Amazônia, Manaus; ITAIPU, ITAIPU Binacional, Estacion de Acuicultura, Asuncion; IU, former Indiana University collections (now dispersed to various repositories); LACM, Los Angeles County Museum of Natural History; LIRP, Laboratorio de Ictiologia de Ribeirão Preto, Universidade de São Paulo, Ribeirão Preto; MBUCV, Museo de Biología, Universidad Central de Venezuela, Caracas; MCNG, Museu de Ciencias Naturales, Guanare; MCP, Museu de Ciências e Tecnologia, Pontificia Universidade Católica do Rio Grande do Sul, Porto Alegre; MCZ, Museum of Comparative Zoology, Cambridge; MEPN, Museo, Escuela Politécnica Nacional, Quito; MHNG, Muséum d'Histoire naturelle, Geneva; MNHN, Muséum National d'Histoire naturelle, Paris; MNRJ, Museu Nacional, Rio de Janeiro; MPEG, Museu Paraenese "Emilio Goeldi," Belém; MUSM, Museo de Historia Natural de la Universidad Nacional Mayor de San Marcos, Lima; MZUSP, Museu de Zoologia, Universidade de São Paulo, São Paulo; NMNH, National Museum of Natural History, Smithsonian Institution, Washington, D.C.; NMW, Naturhistorisches Museum Wien, Vienna; NRM, Swedish Museum of Natural History, Stockholm; NZCS, National Zoological Collection of Suriname, Paramaribo; ROM, Royal Ontario Museum, Toronto; TNHC, Texas Natural History Collections - Ichthyology, Austin; UF, Florida Museum of Natural History, Gainesville; UMMZ, University of Michigan, Museum of Zoology, Ann Arbor; USNM, former United States National Museum, collections in NMNH; ZMB, Museum für Naturkunde der Humboldt Universität, Zoologisches, Museum, Berlin; and ZMH, Zoologisches Institut und Zoologisches Museum, Hamburg.

\section{Results}

\section{Subfamily Cetopsinae}

Systematic Overview. In the following sections we treat the recognized genera and species of the Cetopsinae. According to the results of this study, the Cetopsinae includes 37 species in four genera. Each of these genera, Cetopsidium, Cetopsis, Denticetopsis, and Paracetopsis, is hypothesized to form a monophyletic lineage (unpublished results) and is 
externally diagnosable by a series of morphological characters detailed under their respective "Diagnosis." The concepts of both Denticetopsis and Cetopsis are herein expanded beyond their previous limits to include species formerly assigned to other genera. It proved necessary to place Bathycetopsis, Hemicetopsis, and Pseudocetopsis into the synonymy of Cetopsis in light of the arrived-at scheme of phylogenetic relationships. Such a synonymy is preferable to the alternative of the continued recognition of any, or all, of the nominal genera synonymized herein into Cetopsis, an action that would necessitate the proposal of a series of additional generic names in order that all recognized genera would be monophyletic. The resulting complex generic-level classification would be confusing and more importantly, unnecessarily difficult to utilize given the subtle external differences between some of the clades within Cetopsis.

As discussed by de Pinna \& Vari (1995) and de Pinna (1998) the Cetopsinae are diagnosed by a series of internal and external synapomorphies. Most of these features, most notably the internal characters are not, however, applicable to the problem of the rapid recognition of specimens as members of that subfamily. Externally the species of the Cetopsinae are distinguished from other taxa in the Siluriformes by the combination of their lack of an adipose fin, the absence of bony plates on the body, the proportionally-elongate base of the anal fin, the absence of nasal barbels, and the relatively extensive integumentary layer covering the eye when that organ is present.

In order to facilitate cross-reference between the species accounts in this paper, we arrange the genera, and the species within genera, alphabetically.

\section{Keys to the species of the Cetopsinae}

Our results demonstrate that the faunas of the Cetopsinae on the two sides of the Andean Cordilleras are completely distinct at the species level, with only Cetopsis, the most speciose genus in the subfamily, being present on both the Atlantic and Pacific slopes of South America. Such specieslevel allopatry renders it most efficient to provide two keys to the members of the subfamily, one for the Trans-Andean and the other for the Cis-Andean species. The key to the TransAndean species includes the members of the subfamily occurring in the Lago Maracaibo basin of northwestern Venezuela and northeastern Colombia. The diagnosis under each species account further serves to unequivocally distinguish each species from all other members of the Cetopsinae to both sides of the Andean Cordilleras.

\section{Key to the species of the Cetopsinae occurring in Trans-Andean South America}

1. Vomerine teeth arranged in patches formed of 2 or 3 rows of teeth laterally and with patches separated by medial gap equivalent to width of 1 to 4 vomerine teeth .............. 2

1 '. Vomerine teeth arranged in single tooth row continuous across midline
2. Dorsal profile of body without distinct notch at rear of head in area of contact of posterodorsal portion of externally obvious jaw musculature and anterior portion of epaxial musculature (see Fig. 57) (Pacific Ocean versant rivers of northwestern Ecuador)

Paracetopsis esmeraldas, new species

2 '. Dorsal profile of body with distinct notch at rear of head in area of contact of posterodorsal portion of externally obvious jaw musculature and anterior portion of epaxial musculature (see Figs. 54, 56) .

3. Pelvic fin extending posteriorly to completely overlap vent and nearly reaching to anal-fin origin; vomerine teeth with medial gap equivalent to width of 1 or 2 vomerine teeth (río Tumbes and río Zarumilla, western Peru and Ecuador) Paracetopsis atahualpa, new species

3'. Pelvic fin extending posteriorly to barely reach anterior limit of vent and falling distinctly short of anal-fin origin; vomerine tooth row with medial gap equivalent to width of 3 or 4 vomerine teeth (río Guayas and río Santa Rosa basin, southwestern Ecuador) ..... Paracetopsis bleekeri

4. Distal margins of pectoral and anal fins with distinct, dark pigmentation (río Nercua of río Atrato basin, northwestern Colombia) ............ Cetopsis fimbriata, new species

4'. Distal margins of pectoral and anal fins lacking dark pigmentation

5. Caudal fin darkly pigmented throughout other than for narrow, pale, distal margin (lago Maracaibo basin)

Cetopsis motatanensis

5 '. Caudal fin not darkly pigmented ....................... 6

6. Mouth moderate, its width much less than one-half of HL and approximately equal to distance from tip of snout to posterior margin of orbit (río Magdalena and río Sinú, northwestern Colombia) ................. Cetopsis othonops

6 '. Mouth wide, its width equal to approximately one-half of $\mathrm{HL}$ .7

7. Branched anal-fin rays 20 to 22 (río Baudo, western Colombia). Cetopsis baudoensis

7'. Branched anal-fin rays 23 or more ......................... 8

8. Anal-fin origin located approximately at vertical through middle of SL and distinctly anterior of middle of TL; 8, rarely 9, pectoral-fin rays; 29 to 33 total anal-fin rays (río San Juan, río Atrato, and río Patia of southwestern Colombia, rivers of northwestern Ecuador) .................. Cetopsis amphiloxa

8'. Anal-fin origin located distinctly posterior of vertical through middle of SL and approximately at middle of TL; 9 pectoral-fin rays; 28 total anal-fin rays (río Jurubidá, western Colombia) ....................... Cetopsis jurubidae

\section{Key to the species of the Cetopsinae occurring in Cis-Andean South America}

1. First pectoral-fin ray spinous for basal one-half of its length

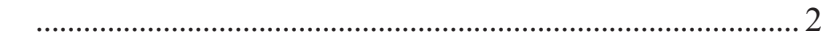

1'. First pectoral-fin ray not spinous .................................... 14

2. Dorsal fin with first ray not spinous; caudal-fin margin obliquely-truncate; vomer without teeth; dentary teeth enlarged proximate to symphysis .................................. 3 
2'. Dorsal fin with first ray spinous; caudal fin either forked or emarginate; vomer with teeth; dentary teeth not noticeably enlarged proximate to symphysis

3. Membranous attachment between anal and caudal fins deeply incised; depth of body at dorsal-fin origin less than $20 \%$ of SL (upper río Negro, Venezuela) .............. Denticetopsis sauli

3'. Membranous attachment between anal and caudal fins not notched or incised; depth of body at dorsal-fin origin approximately $25 \%$ of SL (upper río Negro, Venezuela) Denticetopsis royeroi

4. Pigmentation on body consisting of dark, horizontallyelongate chromatophores (when expanded); caudal fin shallowly-forked with longest principal caudal-fin ray approximately $1 \frac{1}{2}$ times length of middle fin rays; mental barbels falling short of posterior margin of opercle; dorsal fin without ossified spinelet anterior of dorsal-fin spine

4'. Pigmentation on body consisting of, dark, stellate chromatophores (when expanded); caudal fin deeply-forked with longest principal caudal-in ray approximately 2 times length of middle fin rays; mental barbels extending beyond posterior margin of opercle; dorsal fin with ossified spinelet anterior of dorsal-fin spine ... 9

5. Head globose, wide (0.77-0.84 of HL), its postorbital margins distinctly convex from dorsal view (Essequibo River, Guyana) Denticetopsis macilenta

5'. Head not globose, moderately wide (0.61-0.74 of HL), its postorbital margins running nearly in parallel from dorsal view .

6. Premaxilla with 2 rows of teeth in individuals of all sizes (río Baria, Venezuela) .................... Denticetopsis praecox

6'. Premaxilla with 3 rows of teeth, at least in region proximate to symphysis, in all but smallest individuals ................... 7

7. Anal-fin origin located distinctly anterior of middle of TL (western portion of rio Amazonas and río Orinoco basins) Denticetopsis seducta, new species

7'. Anal-fin origin located at middle of TL ............................ 8

8. Anal fin with 29 rays (Siparuni River, Guyana)

Denticetopsis iwokrama, new species

$8^{\prime}$. Anal fin with 25 to 27 rays (rio Tocantins)

Denticetopsis epa, new species

9. Tip of adpressed pelvic fin extending beyond vent and reaching to origin of anal fin (Potaro and Essequibo Rivers, Guyana) . Cetopsidium minutum

9'. Tip of adpressed pelvic fin falling short of, or reaching, vent but always falling short of origin of anal fin ........ 10

10 . Vent located distinctly anterior to base of anterior most anal-fin ray (Rupununi region, southwestern Guyana) Cetopsidium roae, new species

$10^{\prime}$. Vent located proximate to base of anterior most anal-fin ray. 11

11. Dark pigmentation on body limited to middorsal region; tips of first rays of dorsal and pectoral fins without distal filaments (rio Trombetas, Brazil)

Cetopsidium ferreirai, new species
11'. Dark pigmentation on body distributed over all of dorsal and lateral surfaces; tips of first rays of dorsal and pectoral fins of mature males with distal filaments ................... 12

12. Ventral surface of lower jaw with broad band of dark chromatophores; dorsal and ventral portions of postdorsal region of body running in parallel (coastal rivers from Corantijn River, Suriname, to Fleuve Oyapock, French Guyana, and rio Tocantins and rio Xingu, Brazil) .

Cetopsidium orientale

$12^{\prime}$. Ventral surface of lower jaw with single or incomplete row of dark chromatophores; dorsal and ventral portions of postdorsal region of body converging posteriorly ....... 13

13. Dorsal and lateral surfaces of body with uniformly-distributed, dark chromatophores; dark chromatophores typically small and round (río Caroni, río Caura, Venezuela; río Meta, Colombia; upper rio Branco, Brazil)

..................... Cetopsidium pemon, new species

13 '. Dorsal and lateral surfaces of body with dark chromatophores concentrated dorsally; dark chromatophores large and stellate (central and western portions of río Orinoco basin)

Cetopsidium morenoi

14. Eyes absent; filaments on first rays of dorsal and pectoral fins extremely elongate; first dorsal-fin ray longer than 0.50 of SL; first pectoral-fin ray extending posteriorly to beyond vertical through middle of base of anal fin; body length less than $36 \mathrm{~mm} \mathrm{SL}$ (middle and upper portions of Amazon basin) Cetopsis oliveirai

14'. Eyes present and always obvious to some degree; filaments on first rays of dorsal and pectoral absent or only moderately-developed; body length of adults distinctly greater than $36 \mathrm{~mm} \mathrm{SL}$ 15

15. Posterior nares in form of transverse slit; medial margins of contralateral nares separated by distance distinctly less than one-half of distance between contralateral anterior nares (río Orinoco, rio Amazonas, and rio Tocantins basins) Cetopsis coecutiens

15 '. Posterior nares rounded; medial margins of contralateral nares separated by distance slightly less than distance between contralateral anterior nares 16

16. Teeth on dentary, premaxilla, and vomer incisiform and arranged in single rows (Amazon basin) ........ Cetopsis candiru

16 '. Teeth on dentary, premaxilla, and vomer conical with multiple tooth rows on premaxilla and usually with multiple tooth rows on dentary ................................................ 17

17. Base of caudal fin with posteriorly-rounded, variably-developed, bilobed patch of dark pigmentation .................. 18

17 '. Base of caudal fin without posteriorly-rounded, variablydeveloped, bilobed patch of dark pigmentation .............. 23

18. Dark pigmentation on sides of body only in form of very small, spots (upper portions of rio Madeira basin, Bolivia) Cetopsis pearsoni, new species

18'. Dark pigmentation on sides of body with eye-size, or larger spots . .19

19. Dark pigmentation on sides of body limited to eye-size spots (western portions of Amazon basin in Peru and Ecuador) …........................ Cetopsis montana, new species 
19'. Dark pigmentation on sides of body consisting of both eye-size, or larger, spots and very small spots

20. Caudal fin dusky overall with numerous, dark chromatophores extending nearly to posterior margin of fin; dorsal fin with distinct spot of dark pigmentation basally; dorsal fin with dark pigmentation present on first interradial membrane ........... 21

20'. Caudal fin pale other than for dark basal pigmentation, with few scattered, dark chromatophores posterior of dark bilobed basal spot; dorsal fin pale or if dark pigmentation present, then not forming distinct basal spot; dorsal fin without dark pigmentation on first interradial membrane 22

21. Distinct demarcation present between dark pigmentation on dorsal and dorsolateral surfaces of body versus more ventral regions; dark spots of eye-size or larger limited to portion of lateral surface of body dorsal of horizontal through ventral margin of caudal peduncle (rio Tocantins, Brazil) ............................ Cetopsis arcana, new species

21 '. No distinct demarcation present between dark pigmentation on dorsal and dorsolateral surfaces of body versus more ventral regions; dark spots of eye-size or larger present on ventrolateral surfaces of body below horizontal through ventral margin of caudal peduncle (rio Tapajós, Brazil) ............................. Cetopsis sandrae, new species

22. Dark pigmentation on body extending onto base of anal-fin rays; 21 branched anal-fin rays (western portions of río Orinoco basin, Colombia) ............. Cetopsis umbrosa, new species

22 '. Dark pigmentation on body not extending onto base of analfin rays; 22 or 23 branched anal-fin rays (southern portion of rio Madeira basin, Bolivia; northwestern portion of río de La Plata basin, Bolivia) ............ Cetopsis starnesi, new species

23. Dark humeral spot present .............................................. 24

23'. Dark humeral spot absent .............................................. 27

24. Pectoral fin darkly pigmented except along distal margin (western portions of Amazon basin, Peru and Ecuador, and northwestern portion of rio Negro, Brazil) ............... Cetopsis parma

24'. Pectoral fin pale ................................................................ 25

25. Body with eye-size or larger, dark spots at least on dorsal surface; caudal fin with dark pigmentation extending nearly to distal margin (río Orinoco, río Aroa, and río Yaracuy, Venezuela) Cetopsis orinoco

$25^{\prime}$. Body lacking eye-size or larger, dark spots at least on dorsal surface; caudal fin lacking dark pigmentation on rays ...... 26

26. Pectoral-fin rays 8; branched anal-fin rays 18 (rio Tocantins, Brazil) .............................. Cetopsis caiapo, new species

26'. Pectoral-fin rays 9; branched anal-fin rays 21 (rio Tocantins, Brazil) ........... Cetopsis sarcodes, new species

27. Anterior and lateral surfaces of snout without dark pigmentation; dorsal fin with dark semicircular spot basally and remainder of fin pale (upper portions of rio São Francisco basin, rio Juquiá in Brazil, rio Paraná, río Uruguay, upper río Paraguay) ........................................ C. gobioides

27 '. Anterior and lateral surfaces of snout with dark pigmentation; dorsal fin with extensive distribution of dark pigmentation across fin; first dorsal-fin ray darkly pigmented (western portions of Amazon basin in Bolivia, Ecuador, and Peru) C. plumbea

\section{Genus Cetopsidium new genus}

Type-species. Pseudocetopsis orientale Vari, Ferraris, \& Keith, 2003. Gender: Neuter.

Diagnosis. The combination of the presence of a dorsal fin with an ossified spinelet and the presence of pectoral- and dorsal-fin spines distinguishes the species of Cetopsidium from all other genera in the Cetopsinae. The possession of a lateral line extending to over the posterior portion of the base of the anal fin but falling short of the caudal peduncle is also unique to Cetopsidium within the Cetopsinae. The other genera within the Cetopsinae either have a shorter lateral line that is restricted to the abdominal portion of the body (Denticetopsis royeroi and D. sauli) or have a longer lateral line extending posteriorly at least onto the posterior portion of the caudal peduncle (all members of the Cetopsinae with the exception of Denticetopsis royeroi and D. sauli and the species of Cetopsidium). Cetopsidium is further distinguished from Denticetopsis by having the mental barbels extending posteriorly beyond the rear margin of the opercle versus falling short of that point, respectively, and in having a deeplyforked caudal-fin margin in contrast to an emarginate or obliquely-truncate caudal-fin margin, respectively.

Etymology. The genus name, Cetopsidium, from Cetopsis, that was the first genus proposed in the Cetopsinae, and "idium" meaning diminutive, is in reference to the relatively small body sizes of the members of the genus.

\section{Cetopsidium ferreirai, new species}

Figs. 1-2, Tables 2-8

\section{Pseudocetopsis minuta [not of Eigenmann, 1912].-Ferreira,} 1995: 52, table 3 [Brazil: Pará, rio Trombetas basin].

Diagnosis. Cetopsidium ferreirai differs from all of its congeners with the possible exception of $C$. roae and $C$. minutum (see those species accounts) in the lack of distal filaments on the first rays of the dorsal and pectoral fins in adult males (versus the presence of such filaments in adult males as indicated by the possession of distinctly convex anal-fin margins, respectively). Cetopsidium ferreirai further differs from C. minutum in the length of the pelvic fin (falling short of anal-fin origin versus extending at least to anal-fin origin, respectively). Cetopsidium ferreirai further differs from $C$. morenoi in the overall form of the head (the head being not massive proportionally as a consequence of the less extensive development of the adductor mandibulae muscle onto the dorsal surface of head and with the snout distinctly rounded versus the head being proportionally massive with well-developed, distinctly bulging adductor mandibulae muscles and the snout less rounded, respectively; compare Fig. 1 with Figs. 5, 6), and the less extensive dark pigmentation on the body (the near absence of dark pigmentation on the lateral surface of body and the pigmentation limited to the 


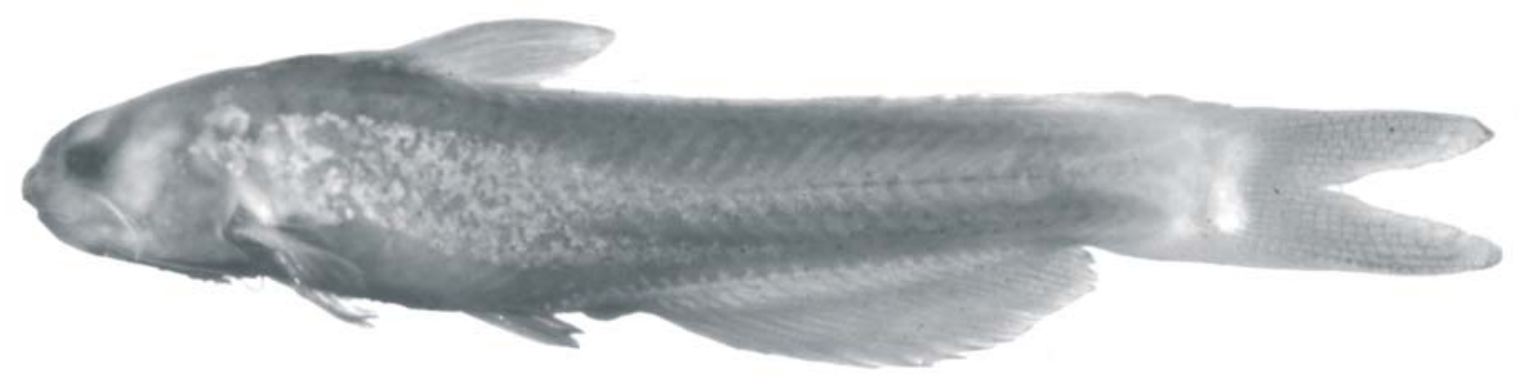

Fig. 1. Cetopsidium ferreirai, new species, holotype, male, INPA 10194, 25 mm SL; Brazil, Pará, rio Trombetas basin, rio Mapuera, last cachoeira before the rio Trombetas (approximately $1^{\circ} 05^{\prime} \mathrm{S}, 57^{\circ} 01^{\prime \prime} \mathrm{W}$ ).

middorsal region of body versus the dark pigmentation being distributed over much of the lateral and dorsal surfaces of the body, respectively). Cetopsidium ferreirai further differs from C. orientale in the alignment of the dorsal and ventral profiles of the portion of the body posterior of the base of the dorsal fin (profiles converging posteriorly versus running in parallel, respectively) and in the overall coloration (limited dark pigmentation located largely along the middorsal region of the body versus dark pigmentation widely distributed over the dorsal and lateral portions of body, respectively). Cetopsidium ferreirai further differs from $C$. pemon in the overall form of the head (profile of head anteriorly rounded versus distinctly pointed, respectively) and in the proportional length of the snout (approximately 2 times diameter of the eye versus approximately 3 times diameter of the eye, respectively). Cetopsidium ferreirai further differs from $C$. roae in the position of the vent (proximate to the base of the anterior most anal-fin ray versus distinctly separated from the base of the anterior most anal-fin ray, respectively).

Description. Body elongate, barely compressed laterally anteriorly and becoming progressively distinctly-compressed posteriorly. Body depth at dorsal-fin origin approximately 0.18 0.20 of SL, and slightly less than HL. Lateral line on body incomplete, unbranched, and midlateral; extending posteriorly to over posterior portion of base of anal fin but falling short of caudal peduncle. Dorsal profile of body slightly convex from nape to dorsal-fin origin and straight from dorsal-fin origin to caudal-fin base. Ventral profile of body slightly convex along abdomen, approximately straight, and nearly running in parallel to dorsal profile along region of caudal peduncle. Caudal-peduncle depth approximately equal to caudal-peduncle length.

Head in profile acutely triangular overall with bluntlypointed snout. Dorsal profile of head convex from tip of snout to vertical through posterior margin of orbit and nearly straight from that point to nape. Ventral profile of head slightly convex. Margin of snout rounded from dorsal view. Lateral margins of postorbital portion of head slightly convex on each side from dorsal view. Enlarged jaw musculature very evident externally on dorsal and lateral surfaces of postorbital portion of head.
Opercular membrane attaching to isthmus only anterior of vertical through pectoral-fin insertion. Opercular opening moderately-elongate; extending anteroventral of pectoral-fin insertion by distance approximately equal to one-third of HL and extending dorsal of pectoral-fin insertion by distance equal to diameter of eye.

Eye situated on lateral surface of head; located entirely dorsal to horizontal through pectoral-fin insertion; eye visible in dorsal view, but not in ventral view, of head. Middle of orbit at approximately anterior one-third of HL. Eye diameter slightly more than one-half of snout length. Interorbital width approximately equal to distance from tip of snout to middle of orbit. Anterior narial opening circular, surrounded by short, anteriorly-directed, tubular rim of skin. Opening of anterior nares located slightly dorsal of horizontal extending through maxillary-barbel origin and at, or slightly ventral of, horizontal extending through tip of snout. Distance between anterior nares approximately equal to distance from tip of snout to posterior margin of orbit. Posterior narial opening located on dorsal surface of head, situated dorsal to anterior one-third of orbit; narial opening nearly round and with flap of skin extending along anterior one-half of rim of aperture, with flap highest anteriorly.

Mouth subterminal, its width approximately two-fifths of HL. Margin of lower jaw gently rounded, its posterior limit reaching to vertical through middle of orbit. Premaxillary tooth patch in form of gently-arched band continuous across midline and with anterior margin convex and posterior margin concave and running in parallel to anterior margin. Teeth on premaxilla small, conical, and sharply-pointed, with teeth arranged in two, more or less regular, rows of uniform-sized teeth medially and reduced to one row at lateral limit of premaxilla. Vomerine teeth arranged in single, arched row with distinct gap in series at midline. Vomerine teeth stout and conical, and either of uniform size or becoming progressively slightly larger laterally, but with even smallest teeth in series larger than teeth on premaxilla. Dentary teeth comparable in shape to, but larger in size than, premaxillary teeth and consisting of two or three irregular rows medially that taper to one row laterally.

Maxillary barbel slender, its length slightly greater than distance from anterior margin of orbit to rear of head and 
approximately three-fourths of HL; barbel origin located ventral to anterior margin of orbit. Medial mental barbel approximately equal in length to lateral mental barbel, with latter slightly shorter than maxillary barbel. Medial mental-barbel origin located along vertical through rictus. Lateral mentalbarbel origin situated slightly posterior of vertical through medial mental-barbel origin. Tips of adpressed mental barbels extending slightly beyond posterior margin of opercle.

Dorsal fin moderately large overall with length of dorsalfin base approximately $0.33-0.35$ of HL. Length of longest branched dorsal-fin ray equal to approximately two-thirds of HL. Dorsal-fin spinelet present. First dorsal-fin ray spinous for basal one-half of length and flexible more distally. First dorsal-fin ray lacking distal filament in all examined specimens including mature males as evidenced by presence of distinctly convex anal-fin margin. Distal margin of dorsal fin convex, with second branched fin ray longest. Dorsal-fin origin located at approximately anterior $0.29-0.30$ of SL and along vertical extending through posterior one-half of adpressed pectoral fin. Tip of adpressed dorsal fin extending to vertical through vent. Posterior most dorsal-fin ray with slight basal, posterior, membranous attachment to body.

Caudal fin deeply-forked, symmetrical; tips of lobes bluntly pointed. Length of longest caudal-fin rays approximately two times length of middle fin rays.

Base of anal fin moderately long. Anal-fin origin located posterior of middle of SL but falling short of middle of TL. Anal-fin margin nearly straight in apparent females, and broadly convex in apparent mature males (see Fig. 1). Posterior most anal-fin ray with slight membranous attachment to body.

Pelvic fin small; distal margin slightly convex with middle fin rays longest. Pelvic-fin insertion located anterior to middle of SL and along vertical through posterior terminus of base of dorsal fin. Tip of adpressed pelvic fin extending past middle of SL and reaching anterior margin of vent. Medial most pelvic-fin ray with membranous attachment to body along basal one-half of its length.

Pectoral-fin length approximately two-thirds of HL. Pectoral-fin margin distinctly convex with middle ray longest. First pectoral-fin ray spinous with smooth margins; spinous portion of ray short, with length slightly more than one-half that of first branched ray and not prolonged as distal filament in any of examined specimens including apparently mature males (as indicated by broadly convex anal-fin margin).

Coloration in alcohol. All available specimens with most of dark pigmentation apparently lost as consequence of postmortem bleaching. Overall coloration of head and body pale. Abdomen pale. Body with small, scattered, rounded, pale brown spots on dorsal and lateral surfaces in some specimens. Dorsal portion of head pale or with few scattered dark spots dorsally and around orbit. Lateral and ventral surfaces of head otherwise pale. Fine stripe of brown spots distributed along middorsal portion of body in one paratype. Other specimens with overall pigmentation very faint and middorsal stripe not apparent.

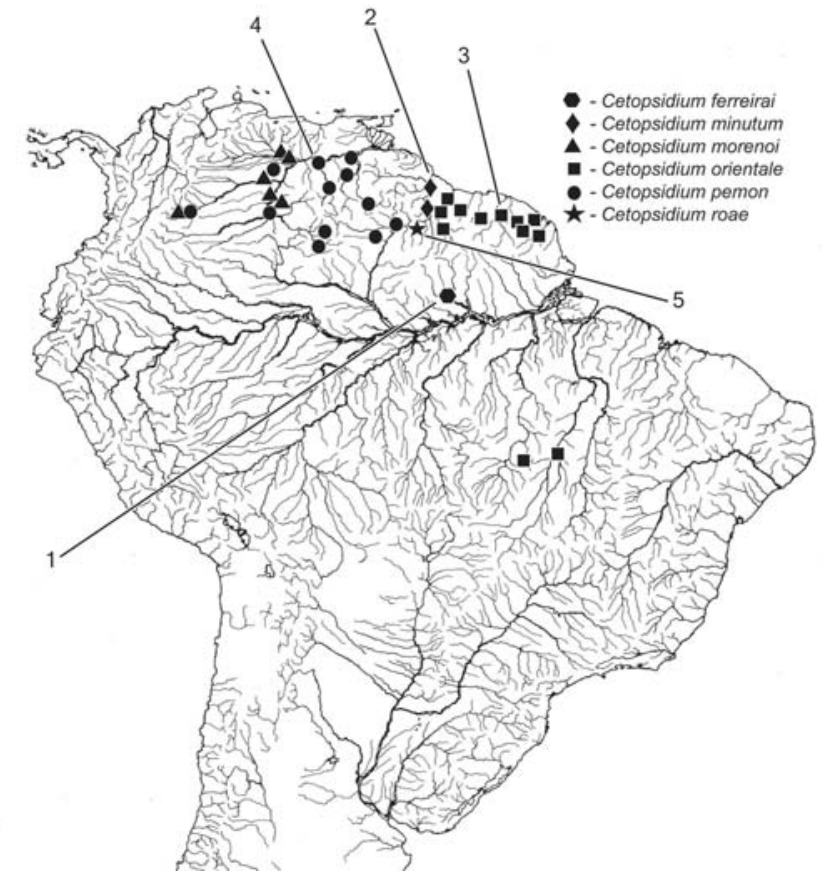

Fig. 2. Map of central and northern South America showing geographic distribution of Cetopsidium ferreirai $(1=$ holotype locality), Cetopsidium minutum ( 2 = holotype locality of Hemicetopsis minutus), Cetopsidium morenoi, Cetopsidium orientale ( $3=$ holotype locality of Pseudocetopsis orientale), Cetopsidium pemon ( 4 = holotype locality), and Cetopsidium roae ( 5 = holotype locality) (some symbols represent more that one locality and/or lot of specimens).

Dorsal fin pale or with few, scattered, dark spots at base. Anal fin pale or with fine, very widely scattered, dark pigment spots basally. Caudal fin with few, scattered, dark spots basally with remainder of fin pale. Pelvic and pectoral fins pale. All barbels pale.

Sexual dimorphism. A portion of the examined population samples of Cetopsidium ferreirai are characterized by the presence of an anal-fin margin that is broadly convex in contrast to the straight fin margin present in the remainder of the examined material of the species. Such a broadly convex anal-fin margin typifies mature males of other sexually dimorphic species in the Cetopsinae and individuals with that attribute are consequently considered to be mature males. The presumed mature males lack, however, the distal filaments on the first rays of the dorsal and pectoral fins that usually characterize mature males of sexually-dimorphic species within the Cetopsinae.

Distribution. Cetopsidium ferreirai is known only from the rio Trombetas, a left bank tributary of the lower rio Amazonas (Fig. 2; see also under "Remarks").

Etymology. The species name, ferreirai, is in honor of Efrem J. G. Ferreira of the Instituto Nacional de Pesquisas da 


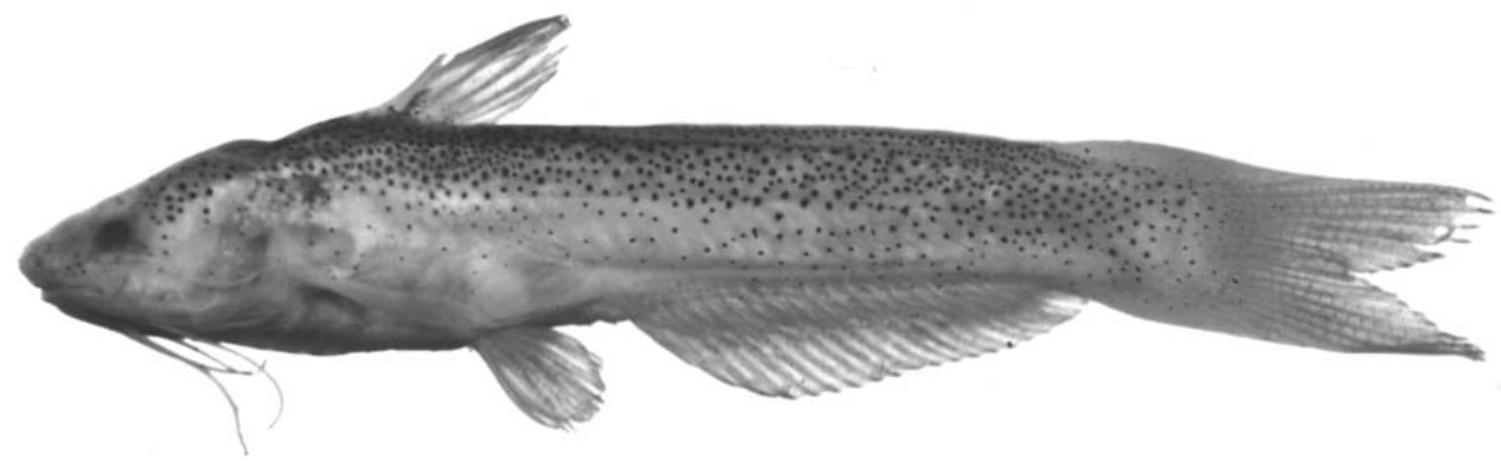

Fig. 3. Cetopsidium minutum, ANSP 175839, $21 \mathrm{~mm}$ SL; Guyana, Siparuni VIII-2, Essequibo River at Essequibo campsite $\left(4^{\circ} 45^{\prime} 41^{\prime \prime} \mathrm{N}, 58^{\circ} 45^{\prime} 53^{\prime \prime} \mathrm{W}\right)$.

Amazônia (INPA), the collector of all the known specimens of the species, in recognition to his contributions to our knowledge of the fishes of the Brazilian Amazon.

Remarks. In his report on the ichthyofauna of the rio Trombetas basin Ferreira (1995: 52) reported Pseudocetopsis minuta (the Cetopsidium minutum of this study) from four regions within that drainage system. According to our results, Cetopsidium minutum is only known from the Essequibo River basin of Guyana, a considerable distance from the localities from which Ferreira's material originated. We have examined specimens from Ferreira's "Região Cachoeira Porteira" (CPT of Ferreira, 1995: Table 3) and "Região Mapuera" (MAP of Ferreira, 1995: Table 3) and find that these population samples represent a previously undescribed species that we describe herein as Cetopsidium ferreirai. Given those findings we assume that Ferreira's references of Pseudocetopsis minuta from "Região Oriximiná" (ORI of Ferreira, 1993: Table 3) and "Região Caxiaporé" (CAX of Ferreira, 1993: Table 3) likely also refer to Cetopsidium ferreirai.

Material examined. 7 specimens (7, 25-37 mm SL). Holotype. Brazil. Pará: rio Trombetas basin, rio Mapuera, last cachoeira before rio Trombetas (approximately $1^{\circ} 05^{\prime} \mathrm{S}, 57^{\circ} 01^{\prime} \mathrm{W}$ ), INPA 10194 , male, 25 mm SL; E. J. G. Ferreira, 19 April 1985. Paratypes. 6 specimens $(6,25-37 \mathrm{~mm} \mathrm{SL})$ Brazil. Pará: rio Trombetas, above Cachoeira Porteira (approximately $1^{\circ} 05^{\prime} \mathrm{S}, 57^{\circ} 01^{\prime} \mathrm{W}$ ), INPA 10193 , 3 (26-33), E. J. G. Ferreira, 19 April 1985. rio Trombetas, Cachoeira Porteira (approximately $\left.1^{\circ} 05^{\prime} \mathrm{S}, 57^{\circ} 01^{\prime} \mathrm{W}\right)$, INPA 6501, 3 (25-37; 1 specimen, $37 \mathrm{~mm}$, cleared and stained), E. J. G. Ferreira, 19 April 1985.

\section{Cetopsidium minutum (Eigenmann, 1912)}

Figs. 2, 3, Tables 2-8

Hemicetopsis minutus Eigenmann, 1912a: 211, pl. 23, fig. 2 [type locality: British Guiana (=Guyana), Amatuk Cataract].-Henn, 1928: 81 [holotype depository].-Ibarra \& Stewart, 1997: 44 [holotype depository].-Burgess, 1989: 292 [Guyana].-[Not Mago-Leccia, 1970: 82; Fernández-
Yépez, 1972: 19, fig. on page 20; Lasso et al., 1990: 117; Taphorn et al., 1997: 85]

Pseudocetopsis minutus.-Evers \& Seidel, 2002: 741 [listing]. Pseudocetopsis minuta.-Vari \& Ferraris, 2003: 250 [in check list; distribution, in part, only Guyana].

Diagnosis. Cetopsidium minutum differs from all other species of Cetopsidium in the length of the pelvic fin (tip of fin reaching posteriorly to the anal-fin origin versus only reaching or falling short of the vent, respectively). Cetopsidium minutum differs from all other species of Cetopsidium with the exception of C. pemon in the length of the pectoral fin (tip of fin reaching to the vertical through the pelvic-fin insertion versus falling distinctly short of that line, respectively). Cetopsidium minutum further differs from $C$. orientale and C. roae in the relative alignment of the dorsal and ventral profiles of the portion of the body posterior of the terminus of the base of the dorsal fin (converging posteriorly versus running in parallel, respectively). Cetopsidium minutum also differs from C. roae in the relative position of the vent (located proximate to the base of the anterior most anal-fin ray versus located distinctly anterior to the base of the anterior most anal-fin ray, respectively).

Description. Body elongate, barely compressed laterally anteriorly and becoming progressively distinctly-compressed posteriorly. Body depth at dorsal-fin origin approximately 0.17 0.18 of SL, and decreasing slightly from dorsal-fin origin to caudal peduncle and approximately equal to, or slightly greater than, distance from anterior margin of orbit to posterior margin of opercle. Lateral line on body incomplete, unbranched, and midlateral; extending from vertical through pectoral-fin base posteriorly to region dorsal of base of anal fin but falling short of caudal peduncle. Dorsal profile of body straight to slightly convex from nape to dorsal-fin origin and straight from dorsal-fin origin to caudal-fin base. Ventral profile of body slightly convex along abdomen, approximately straight and slightly converging with dorsal profile of body posteriorly. Caudal-peduncle depth approximately equal to caudalpeduncle length. 
Head in profile acutely triangular overall with bluntlypointed snout. Dorsal profile of head slightly convex from tip of snout to nape. Ventral profile of head slightly convex, more so anteriorly. Margin of snout in dorsal view rounded. Postorbital margins of head slightly convex on each side from dorsal view. Enlarged jaw musculature very evident externally on dorsal and lateral surfaces of postorbital portion of head.

Opercular membrane attaching to isthmus only anterior of vertical through pectoral-fin insertion. Opercular opening moderately-elongate; extending anteroventral of pectoral-fin insertion by distance approximately equal to one-half of $\mathrm{HL}$ and extending dorsal of pectoral-fin insertion by distance equal to diameter of eye.

Eye situated on lateral surface of head; located entirely dorsal to horizontal extending through pectoral-fin insertion; eye visible in dorsal view, but not in ventral view, of head. Middle of orbit at approximately anterior $0.29-0.30$ of HL. Eye diameter approximately one-third of snout length. Interorbital width approximately equal to distance from tip of snout to slightly beyond posterior margin of orbit. Anterior narial opening circular, surrounded by short, anteriorly-directed, tubular rim of skin. Opening of anterior nares located slightly dorsal of horizontal extending through maxillary-barbel origin and at, or slightly ventral of, horizontal running through tip of snout. Distance between anterior nares approximately equal to distance from tip of snout to posterior margin of orbit. Posterior narial opening located on dorsal surface of head, situated dorsal to anterior one-third of orbit. Narial opening nearly round and with flap of skin extending along anterior one-half of rim of aperture, with flap highest anteriorly.

Mouth subterminal, its width approximately two-thirds of HL. Margin of lower jaw gently rounded, its posterior limit reaching to vertical through middle of orbit. Premaxillary tooth patch in form of gently-arched band, continuous across midline and with anterior margin convex and posterior margin concave and running in parallel to anterior margin. Teeth on premaxilla small, conical, and sharply-pointed. Premaxillary teeth arranged in two irregular rows of uniform sized teeth medially that taper to one row laterally. Vomerine teeth arranged in single, arched row with distinct gap in tooth series along midline. Vomerine teeth stout and conical, and either of uniform size or becoming progressively slightly larger laterally, but with even smallest teeth in series larger than teeth on premaxilla. Dentary teeth comparable in shape to, but larger in size than, premaxillary teeth and arranged in two or three, irregular rows medially that taper to one row laterally.

Maxillary barbel slender, its length slightly greater than distance from anterior margin of orbit to posterior margin of opercle, and slightly greater than two-thirds of HL; barbel origin located ventral to anterior margin of orbit. Medial mental barbel slightly shorter than lateral mental barbel, with latter shorter than maxillary barbel. Medial mental-barbel origin located along vertical through rictus. Lateral mental-barbel origin situated slightly posterior of vertical through medial mental-barbel origin. Tips of adpressed mental barbels extending to, or slightly past, posterior margin of opercle.
Dorsal fin moderately large overall with length of dorsalfin base approximately $0.39-0.41$ of HL. Length of longest branched dorsal-fin ray equal to approximately two-thirds of HL. Dorsal-fin spinelet present. First dorsal-fin ray spinous for basal one-half of length and flexible more distally, and with distal filament present in at least some specimens (see "Remarks"). Distal margin of dorsal fin convex, with second branched ray longest. Dorsal-fin origin located at approximately anterior $0.30-0.32$ of SL and along vertical extending through middle of adpressed pectoral fin. Tip of adpressed dorsal fin falling short of vertical through vent. Posterior most dorsal-fin ray with slight, basal, posterior, membranous attachment to body.

Caudal fin deeply-forked, symmetrical; tips of lobes bluntly pointed. Length of longest caudal-fin ray approximately two times length of middle fin rays.

Base of anal fin moderately long. Anal-fin origin located somewhat posterior of middle of SL but falling short of middle of TL. Posterior most anal-fin ray with slight, membranous attachment to body.

Pelvic fin moderate sized; distal margin slightly convex with middle fin rays longest. Pelvic-fin insertion located anterior to middle of SL and along vertical passing through posterior terminus of base of dorsal fin. Tip of adpressed pelvic fin extending past middle of SL but falling short of posterior margin of vent. Medial most pelvic-fin ray with membranous attachment to body along basal one-half of its length.

Pectoral-fin length approximately two-thirds of HL. Pectoral-fin margin distinctly convex with middle ray longest. First pectoral-fin ray spinous with smooth margins; spinous portion of ray short, with length slightly more than one-half that of first branched ray.

Coloration in alcohol. Overall coloration of head and body pale to dusky, slightly darker dorsally. Abdomen pale. Body with small, scattered, rounded, dark spots on dorsal, dorsolateral, and lateral surfaces; spots extending further ventrally on posterior portion of body and somewhat more concentrated on anterolateral surface of body. Ventral surface of body pale. Head with scattered, dark spots on snout, upper lip, and dorsal surface. Spots more concentrated in region posterodorsal to orbit and with few, scattered, dark spots laterally. Ventral portions of head pale other than for few, scattered, small, dark chromatophores on ventral surface of lower jaw.

Dorsal fin pale except for scattered, dark pigmentation along base of fin. Anal fin pale. Caudal fin with few scattered, dark spots basally and remainder of fin pale. Pelvic and pectoral fins pale.

Maxillary barbel with few spots of dark, basal, pigmentation and otherwise pale. Mental barbels pale.

Sexual dimorphism. No sexual dimorphism was observed in the two examined specimens of Cetopsidium minutum.

Distribution. Cetopsidium minutum occurs in the Potaro River and middle portion of the Essequibo River of Guyana (Fig. 2). 
Remarks. Despite the repeated citations of Cetopsidium minutum in various genera from numerous localities over a broad expanse ranging from the Guianas to adjoining regions, our analysis indicates that only two of the specimens examined in this study are actually that species, both of which originated in the Essequibo River system of Guiana.

The report of Hemicetopsis minutus (=Cetopsidium minutum herein) from the central portions of the río Orinoco basin by Fernández-Yépez (1972: 19, fig. on page 20) is apparently based on specimens of Cetopsidium morenoi of smaller body sizes. Pseudocetopsis minuta was reported by Ferreira (1995: 52, table 3) from the rio Trombetas in the rio Amazonas basin, Pará, Brazil. The material that served as the basis of that record has proved to be an undescribed species, Cetopsidium ferreirai, that is described in this paper. Records of Pseudocetopsis cf. minutus by LeBail et al. (2000: 146) from localities in the Fleuve Maroni, Fleuve Iracoubo, Fleuve Comté, Fleuve Oyapock of French Guiana were based on material that is rather Cetopsidium orientale (Vari et al., 2003: 693).

Mago-Leccia (1970: 82) and Taphorn et al. (1997: 85) reported Hemicetopsis minutus (=Cetopsidium minutum herein) for Venezuela, but our studies failed to demonstrate the occurrence of that species within that country. Although the upper portions of the río Cuyuni that drains eastern Venezuela is a part of the broader Essequibo River basin in which Cetopsidium minutum occurs, that species has not been reported from the Venezuelan portion of the río Cuyuni (Machado-Allison et al., 2000, table 1).

Material examined. 2 specimens (18-21 mm SL). Guyana. Amatuk $\left(5^{\circ} 18^{\prime} \mathrm{N}, 5^{\circ} 18^{\prime} \mathrm{W}\right), \mathrm{FMNH} 53262,1$ (18, holotype of Hemicetopsis minutus). Siparuni VIII-2: Essequibo River at Essequibo campsite $\left(04^{\circ} 45^{\prime} 41^{\prime \prime N}, 58^{\circ} 45^{\prime} 53^{\prime \prime} \mathrm{W}\right)$, ANSP 175839, 1 (21).

\section{Cetopsidium morenoi (Fernández-Yépez, 1972)}

Figs. 2, 4-6, Tables 2-8

Hemicetopsis morenoi Fernández-Yépez, 1972a: 19, unnumbered Fig. on page 20 [type locality: río Aguaro, $1 \mathrm{Km}$. abajo del paso Garcerito, al Oeste franco de Santa Rita, Estado Guárico, Venezuela (=Venezuela, río Aguaro, $1 \mathrm{~km}$ below Paso Garcerito, directly west of Santa Rita, State of Guárico)].-Machado-Allison et al., 1993: 65 [Venezuela, Guarico, ríos Aguaro and Guariquito].

Hemicetopsis cf. morenoi.-Taphorn et al., 1997: 85 [Venezuela].

Pseudocetopsis morenoi.-Evers \& Seidel, 2002: 741 [listing].Vari \& Ferraris, 2003: 259 [in check list; distribution].

Diagnosis. Cetopsidium morenoi differs from $C$. ferreirai in the distal prolongations of the first rays on the dorsal and pectoral fins (present in at least some, presumably mature males, see Fig. 6, versus absent in all specimens, respectively), in the overall form of the head (with well-developed, distinctlybulging adductor mandibulae muscles and with the snout not distinctly rounded versus with head less massive due to less extensive development of the adductor mandibulae on the dorsal surface of the head and with snout distinctly rounded, respectively; compare Figs. 4-6 with Fig. 1), and in the degree of development of the dark pigmentation on the body (dark pigmentation present over much of the lateral and dorsal surfaces of the body versus the near the absence of dark pigmentation on the lateral surface of the body and with the pigmentation limited to the middorsal region of the body, respectively). Cetopsidium morenoi differs from C. minutum in the length of the pelvic fin (falling short of the anterior limit of the vent versus reaching to the anal-fin origin, respectively) and in the length of the pectoral fin excluding the distal filament of the first fin ray in mature males (falling distinctly short of the vertical through the pelvic-fin insertion versus reaching to that line, respectively). Cetopsidium morenoi differs from $C$. orientale in the alignment of the dorsal and ventral profiles of the portion of the body posterior of the dorsal fin (converging posteriorly versus running in parallel, respectively) and apparently in the degree of the development and extent of the dark pigmentation on the body (extensive dark pigmentation not extending onto anal fin but with semicircular dark spot at the base of the dorsal fin versus with limited dark pigmentation extending onto the base of the anal fin in at least some specimens and without the dark blotch of pigmentation at the base of the dorsal fin, respectively), the pigmentation of the rayed portion of the caudal fin (absent versus present on at least the basal one-half of fin, respectively), the middorsal pigmentation on the body posterior of the terminus of the dorsal fin (distinct stripe absent versus present, respectively), and the dark pigmentation on the lower jaw (a single, often incomplete, row of chromatophores versus a broad band of chromatophores, respectively). Cetopsidium morenoi differs from $C$. pemon in the form of the dark pigmentation on the body (formed of large stellate chromatophores versus small, point-like, scattered chromatophores over the dorsal and lateral surfaces of the head), and in the degree of development of the adductor mandibulae muscles (very well-developed and distinctly obvious on the dorsolateral portion of head versus moderately-developed and not distinctly obvious externally, respectively). Cetopsidium morenoi differs from C. roae in the location of the vent (located proximate to the base of the anterior most anal-fin ray versus distinctly separated from the base of the anterior most anal-fin ray, respectively), in the alignment of the dorsal and ventral profiles of the portion of the body posterior of the dorsal fin (converging posteriorly versus running in parallel, respectively), and in the form of the dark pigmentation on the body (formed of large, stellate chromatophores versus small, point-like chromatophores scattered over the dorsal and lateral surfaces of the head, respectively).

Description. Body moderately robust, somewhat compressed laterally anteriorly and becoming progressively distinctlycompressed posteriorly. Body depth at dorsal-fin origin approximately $0.22-0.25$ of SL, and approximately equal to, or 


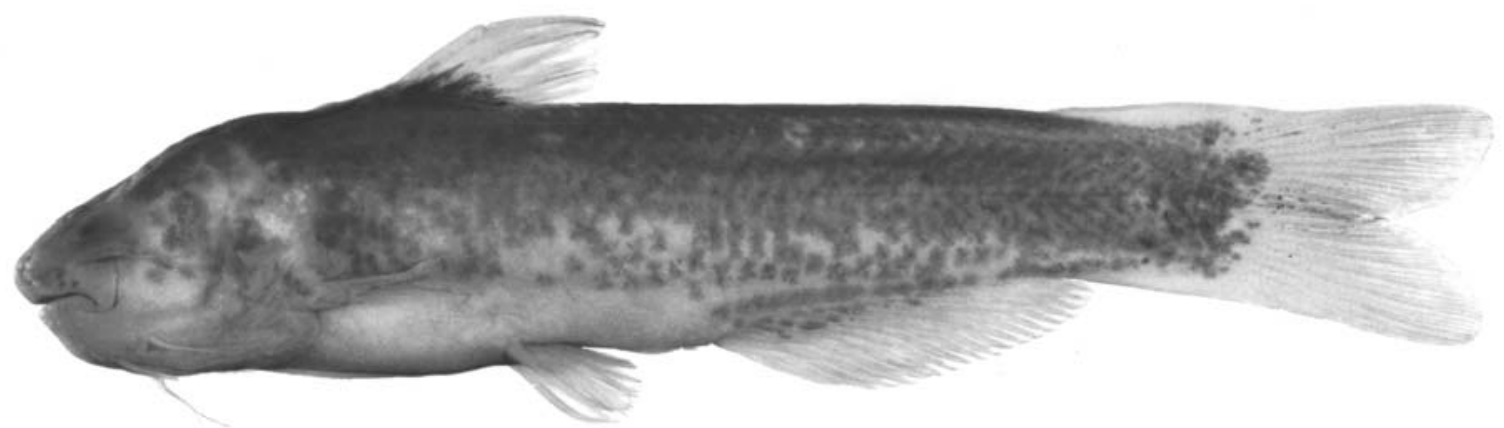

Fig. 4. Cetopsidium morenoi, INHS 61937, 40.0 mm SL; Venezuela, Guarico, río San Bartolo (803’N, 66²²’W).

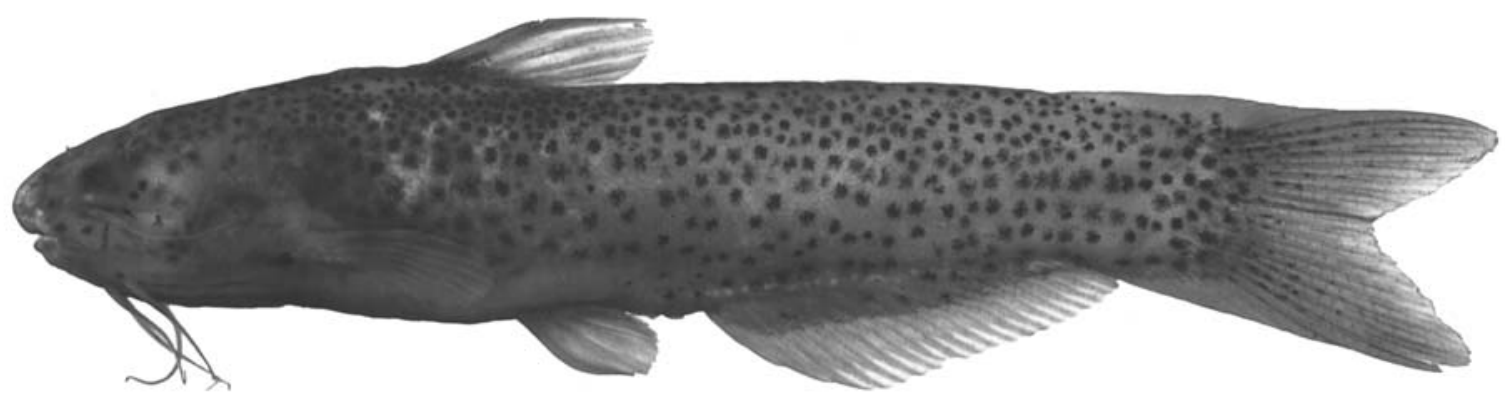

Fig. 5. Cetopsidium morenoi, INHS 34506, 20.5 mm SL; Venezuela, Guarico, río San Bartolo ( $\left.8^{\circ} 03^{`} \mathrm{~N}, 66^{\circ} 42^{\prime} \mathrm{W}\right)$.

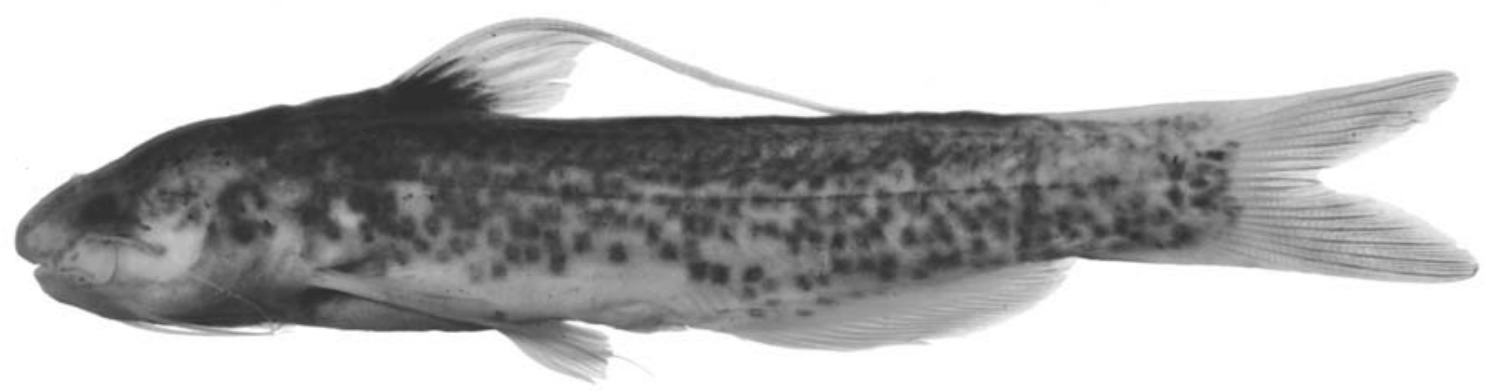

Fig. 6. Cetopsidium morenoi, mature male, ANSP 165734, $43 \mathrm{~mm}$ SL; Venezuela, Apure, Caño Potrerito of río Cinaruco, $24 \mathrm{~km}$ $\mathrm{S}$ of río Cinaruco on San Fernando de Apure to Puerto Paez Highway $\left(6^{\circ} 25^{\prime} \mathrm{N}, 67^{\circ} 32^{\prime} \mathrm{W}\right)$.

slightly less than, HL. Lateral line on body incomplete, unbranched, and midlateral; extending from vertical through pectoral-fin base posteriorly to region dorsal to base of anal fin but falling short of caudal peduncle. Dorsal profile of body slightly convex from nape to dorsal-fin origin and straight from dorsal-fin origin to caudal-fin base. Ventral profile of body slightly convex along abdomen, approximately straight, and slightly posterodorsally-inclined along base of anal fin. Caudal-peduncle depth approximately equal to caudal-peduncle length.

Head in profile acutely triangular overall with bluntlypointed snout. Dorsal profile of head convex anteriorly and then straight to vertical through posterior margin of orbit and convex from that point to nape. Ventral profile of head variably convex. Margin of snout in dorsal view ranging from rounded to bluntly triangular. Postorbital margins of head slightly convex on each side from dorsal view. Enlarged jaw musculature very evident externally on dorsal and dorsolateral surfaces of postorbital portion of head.

Opercular membrane attaching to isthmus only anterior of vertical through pectoral-fin insertion. Opercular opening moderately-elongate; extending anteroventral of pectoral-fin insertion by distance approximately equal to one-half of $\mathrm{HL}$ and extending dorsal of pectoral-fin insertion by distance equal to diameter of eye.

Eye situated on lateral surface of head; located entirely dorsal to horizontal extending through pectoral-fin insertion; eye visible in dorsal view, but not in ventral view, of head. Middle of orbit at approximately anterior $0.25-0.30$ of HL. Eye diameter approximately one-third of snout length. Interorbital 
width approximately equal to distance from tip of snout to middle of orbit. Anterior narial opening circular, surrounded by short, anteriorly-directed, tubular rim of skin. Opening of anterior nares located slightly dorsal of horizontal extending through maxillary-barbel origin and at, or slightly ventral of, horizontal extending through tip of snout. Distance between anterior nares approximately equal to distance from tip of snout to posterior margin of orbit. Posterior narial opening located on dorsal surface of head, situated dorsal to anterior one-half of orbit; narial opening nearly round and with flap of skin extending along anterior two-thirds of rim of aperture, with flap highest anterolaterally.

Mouth subterminal; its width approximately 0.60 of HL. Margin of lower jaw gently rounded, its posterior limit reaching to vertical through middle of orbit. Premaxillary tooth patch in form of gently-arched band, continuous across midline, with anterior margin convex and posterior margin concave and running in parallel to anterior margin. Teeth on premaxilla small, conical, sharply-pointed, and arranged in three irregular rows of uniform-sized teeth medially and tapering to one row laterally. Vomerine teeth arranged in single, arched row with distinct gap in series at midline. Vomerine teeth stout, conical, and of approximately uniform size, with even smallest teeth in series larger than teeth on premaxilla. Dentary teeth comparable in shape to, but larger in size than, premaxillary teeth and arranged in two or three, irregular rows medially that taper to one row laterally.

Maxillary barbel slender, its length approximately slightly greater than distance from anterior margin of orbit to posterior margin of opercle, and slightly greater than three-fourths of HL; barbel origin located ventral to anterior margin of orbit. Medial mental barbel slightly shorter than lateral mental barbel, with latter shorter than maxillary barbel. Medial mental-barbel origin located along vertical through rictus. Lateral mental-barbel origin situated slightly posterior of vertical through medial mental-barbel origin. Tips of adpressed mental barbels extending to, or slightly past, posterior margin of opercle.

Dorsal fin moderately large overall with length of dorsalfin base approximately $0.32-0.37$ of HL. Longest branched dorsal-fin ray, excluding distal filament when present, equal in length to approximately two-thirds of HL. Dorsal-fin spinelet present, first dorsal-fin ray spinous for basal one-half of its length and flexible more distally, with distal filament present in at least some specimens. Distal margin of dorsal fin slightly convex, with first branched ray longest. Dorsal-fin origin located at approximately anterior $0.31-0.34$ of SL and along vertical extending through middle of adpressed pectoral fin. Tip of adpressed dorsal fin reaching to vertical through vent. Posterior most dorsal-fin ray with slight, basal, posterior, membranous attachment to body.

Caudal fin deeply-forked, symmetrical; tips of lobes rounded. Length of longest caudal-fin ray approximately two times length of middle fin rays.

Base of anal fin moderately long. Anal-fin origin located distinctly posterior of middle of SL and approximately at middle of TL. Anal-fin margin nearly straight in most examined specimens, but convex in presumed mature males as evidenced by their distinct filamentous first rays of dorsal and pectoral fins (Fig. 6). Posterior most anal-fin ray with slight, membranous attachment to body.

Pelvic fin small; distal margin slightly convex with middle fin rays longest. Pelvic-fin insertion located anterior to middle of SL and along vertical through posterior terminus of base of dorsal fin. Tip of adpressed pelvic fin extending past middle of SL and barely reaching anterior margin of vent. Medial most pelvic-fin ray with membranous attachment to body along basal one-half of its length.

Pectoral-fin length, excluding distal filament on first ray in mature males, approximately two-thirds of HL. Pectoral-fin margin distinctly convex with middle ray longest. First pectoral-fin ray spinous with smooth margins; spinous portion of ray short with length slightly more than one-half that of first branched ray, prolonged as filament in some, presumably male, specimens (Fig. 6).

Coloration in alcohol. Overall ground coloration of head and body pale and overlain with rounded, brown chromatophores. Chromatophores variably large in most examined specimens (compare Figs. 4 to 6), but relatively small is some individuals from western portions of the distribution of the species. Dark pigmentation on head and body tends to be more concentrated dorsally, with denser concentration of dark pigmentation middorsally posterior of base of dorsal fin. Expanded chromatophores blend together to form uniform brown cast on some portions of body in most specimens (Fig. 4), but constricted and distinctly separated in other individuals (Fig. 5), particularly in population samples from the western portions of the distributional range of the species. Ventral surfaces of abdomen and head pale. Lower lip with single row of dark chromatophores paralleling margin of lip; number of dark chromatophores on lip reduced in some population samples from western portion of the distributional range of the species.

Dorsal fin pale with dark pigmentation forming semicircular basal spot in overall heavily pigmented specimens. Spot at base of dorsal fin ranging from being limited to base of fin to extending to variable degrees beyond basal portions of middle rays of fin. Anal fin pale with scattered, dark chromatophores basally; pigmentation sometimes forming discrete dark spots (Figs. 5, 6). Caudal fin with dark pigmentation along fleshy basal areas and sometimes with dark pigmentation either outlining fin rays or forming spots on interradial membranes. Pelvic and pectoral fins pale.

Maxillary barbel dusky basally and pale distally. Mental barbels pale.

Sexual dimorphism. The presumed mature males of Cetopsidium morenoi have filaments on the first rays of the dorsal and pectoral fins and have the anal-fin margin broadly convex (Fig. 6) rather than being straight or nearly straight as is the case in conspecific females and immature males (Figs. 4, 5). 
Distribution. Cetopsidium morenoi is known from the central and western portions of the río Orinoco basin in Venezuela and Colombia (Fig. 2).

Remarks. The type series of Hemicetopsis morenoi was reported by Fernández-Yépez (1972a: 19) to consist of a holotype and two paratypes. That author neglected to cite either catalog numbers for those lots or the institution in which the specimens were deposited. None of the types of $H$. moreno $i$ were cited as extant in a relatively recent compendium of types deposited in various Venezuelan fish collections (La Marca, 1997). Neither are those specimens known to be present in the holdings of MBUCV (F. Provenzano; pers. commun., 1998); a collection that does include at least portions of the type series of other species of fishes described by Fernández-Yépez (Provenzano et al., 1998: 1). We have, however, examined specimens that we identify as $H$. morenoi that originated at the type locality of that species and that conform with the information provided in the original description of that species by FernándezYépez(1972a).

Fernández-Yépez (1972a) reported the presence of two other species of the Cetopsinae at the type locality of Hemicetopsis morenoi and identified these forms as $H$. minutus and H. macilentus (=Cetopsidium minutum and Denticetopsis macilenta of this study, respectively). Our analysis indicate, however, that both of those species are endemic to the Essequibo River basin of Guyana, a river system that lies a significant distance from the site in the río Orinoco basin from which the samples examined by Fernández-Yépez originated. A comparison of a size range of samples of $H$. moreno $i$ with the specimens illustrated by Fernández-Yépez (1972a) indicates that these two additional "species" reported by Fernández-Yépez most likely represent different earlier ontogenetic stages of $D$. morenoi.

Some specimens in a sample of Cetopsidium morenoi from the western portions of the range of the species from the río Meta basin in Colombia (ANSP 139574) agree with the type species of $C$. morenoi in most examined features. These Colombian specimens differ, however, from the population samples of that species that originated closer to the type locality in having an overall lighter pigmentation. The río Meta samples also differ in having the brown chromatophores in many specimens that are constricted and separate rather than being large and coalesced with each other as is condition typical in many other examined population samples of $C$. morenoi. Further material is necessary to evaluate whether these differences are significant. Until such analyses are possible, the río Meta populations are tentatively identified as $C$. morenoi.

Two lots from outside the core range of Cetopsidium morenoi (MCNG 21688, río Sipapo; MCNG 7623, río Cataniapo) consisted of rather depigmented material; a situation that renders a definitive identification to species impossible. Nonetheless, these specimens agree with that species in meristics, morphometrics, and other examined features and are tentatively identified herein as C. morenoi.

The report of "Hemicetopsis" cf. morenoi from Venezuela by Taphorn et al. (1997: 85) presumably refers to Cetopsidium morenoi. That species was originally described from specimens collected in Central Venezuela.

Material examined. 53 specimens (16-43 mm SL). Colombia. Meta: Quebrada Ventrurosa, 0.25 creek miles $(0.4 \mathrm{~km})$ above road between La Balsa and Puerto Lopez, río Meta drainage $\left(4^{\circ} 05^{\prime} \mathrm{N}\right.$, 7258'W), ANSP 139574, 2 (28-37). Venezuela. Amazonas: río Sipapo, approximately $150 \mathrm{~m}$ from Salto Remo (434'28"N, $\left.67^{\circ} 18^{\prime} 31^{\prime \prime W}\right)$, MCNG 21688, 1 (28). Apure: Caño Potrerito of río Cinaruco, $24 \mathrm{~km} \mathrm{~S}$ of río Cinaruco on San Fernando de Apure to Puerto Paez Highway (6 $\left.{ }^{\circ} 25^{\prime} \mathrm{N}, 6^{\circ} 32^{\prime} \mathrm{W}\right)$, ANSP 165734, 14 (2743). río Cataniapo, Caño Carinaqua, MCNG 7623, 5 (20-38). Guarico: río San Bartolo ( $\left.8^{\circ} 03^{\prime} \mathrm{N}, 66^{\circ} 42^{\prime} \mathrm{W}\right)$, INHS 34506, 1 (20.5); INHS 34065, 12 (16-31.5); INHS 34860, 1 (24.5); INHS 61868, 1 (22); INHS 61937, 7 (16-40); INHS 69416, 8 (22-33). río Mocapra (756’N, 66² $\left.46^{\prime} \mathrm{W}\right)$, INHS 34301, 2 (26.5-34.5). Río Aguaro $\left(7^{\circ} 47^{\prime} \mathrm{N}, 66^{\circ} 25^{\prime} \mathrm{W}\right)$, INHS 34356, 3 (18-24.5). Río San Jose $\left(8^{\circ} 01^{\prime} \mathrm{N}, 67^{\circ} 21^{\prime} \mathrm{W}\right)$, INHS 34613, 1 (22); INHS 34648, 1 (29). Río Aguas Muertas in Las Payaras, Parque Nacional Aguaro-Guariquito ( $\left.8^{\circ} 08^{\prime} 01^{\prime \prime} \mathrm{N}, 66^{\circ} 40^{\prime} 53^{\prime \prime} \mathrm{W}\right)$, MCNG 31796, 3 (23-36).

Cetopsidium orientale (Vari, Ferraris \& Keith, 2003)

Figs. 2, 7, Tables 2-8

Hemicetopsis sp.-Boujard et al., 1990: 347 [French Guiana, Fleuve Arataye].-Ponton \& Copp, 1997: 241 [French Guiana, Fleuve Sinnamary].-Boujard et al., 1997: 126, pl. 18 [French Guiana, Fleuve Approuague].

Pseudocetopsis sp.-Lowe-McConnell, 1991: 69 [Brazil, upper rio Xingu Basin, Suiá Missu Lakes (=flood plain lakes along upper portion of rio Suiá Missu)].

Pseudocetopsis cf. minutus.-LeBail et al., 2000: 146, fig. [French Guiana, Fleuve Maroni, Fleuve Iracoubo, Fleuve Comté, Fleuve Oyapock].

Pseudocetopsis orientale Vari et al., 2003: 693, fig. 1 [type locality: Suriname, Brokopondo District, Mindrineti Kreek, close to mouth of Maykaboeka Kreek, Saramacca River basin, on Gros Rosevel Mining concession $\left(5^{\circ} 07^{\prime} 08.8^{\prime \prime} \mathrm{N}\right.$, $\left.\left.55^{\circ} 16^{\prime} 59.4^{\prime \prime} \mathrm{W}\right)\right]$.

Diagnosis. Cetopsidium orientale differs from C. ferreirai in the degree of development of the first rays of the dorsal and pectoral fins (with distal filaments present in presumed males as indicated by the possession of a distinctly convex anal-fin margin versus distal filaments absent in such specimens, respectively), the relative depth of the body (0.21-0.23 of SL versus $0.18-0.20$ of SL, respectively), the overall coloration pattern (dark pigmentation widely distributed over dorsal and lateral of body versus limited dark pigmentation situated primarily along middorsal region of body, respectively). Cetopsidium orientale differs from C. minutum in the length of the pelvic fin (reaching posteriorly to the anterior margin of the vent versus to the anal-fin origin, respectively), the 
relative depth of the body ( $0.21-0.23$ of SL versus $0.17-0.19$ of SL, respectively), and in the length of the pectoral fin (tip falling distinctly short of the vertical through the pelvic-fin insertion versus reaching that line, respectively). Cetopsidium orientale differs from C. morenoi in the alignment of the dorsal and ventral profiles of the portion of the body posterior of the terminus of the base of dorsal fin (running in parallel versus converging posteriorly, respectively), in the degree of development and extent of the dark pigmentation on the body (limited dark pigmentation extending onto the base of the anal fin in at least some specimens and without dark blotch of pigmentation at the base of the dorsal fin versus extensive dark pigmentation falling short of the base of the anal fin and with a semicircular dark spot present at the base of the dorsal fin, respectively), the distribution of dark pigmentation on the rayed portion of the caudal fin (present on at least basal one-half of fin versus absent, respectively), the form of the dark pigmentation on the middorsal portion of the body posterior terminus of the base of dorsal fin (distinct stripe present versus absent, respectively), and the degree of development of dark pigmentation on the lower jaw (pigmentation in form of a broad band versus consisting of single, often incomplete, row of chromatophores, respectively). Cetopsidium orientale differs from C. pemon in its overall coloration (large, stellate, dark chromatophores densely covering dorsal and lateral surfaces of the head and body versus the small, pointlike chromatophores scattered over the dorsal and lateral surfaces of the head and body, respectively), in the alignment of the dorsal and ventral profiles of the portion of the body posterior of the base of the dorsal fin (running in parallel versus converging posteriorly, respectively), and in the inclination of the predorsal region of the body and head (slightly inclined versus distinctly inclined, respectively). Cetopsidium orientale differs from C. roae in the position of the vent (proximate to the base of the anterior most anal-fin ray versus distinctly separated from that structure, respectively) and in the overall coloration (large, stellate, dark chromatophores densely covering the dorsal and lateral surfaces of the head and body versus the small, point-like chromatophores scat- tered over the dorsal and lateral surfaces of the head and body, respectively).

Description. Body moderately robust, somewhat compressed laterally anteriorly and becoming progressively distinctlycompressed posteriorly. Body depth at dorsal-fin origin approximately $0.21-0.23$ of SL, and approximately equal to distance from anterior margin of eye to posterior margin of opercle. Lateral line on body incomplete, unbranched, and midlateral; extending from vertical through pectoral-fin base posteriorly to point within region delimited anteriorly by vertical through middle of base of anal fin and posteriorly by vertical located proximate to anterior terminus of caudal peduncle. Dorsal profile of body straight, or nearly straight, from nape to dorsal-fin origin and straight from that point to caudal-fin base. Ventral profile of body slightly convex along abdomen, approximately straight along base of anal fin and running parallel posteriorly with dorsal profile of body. Caudal-peduncle depth greater than caudal-peduncle length.

Head in profile acutely triangular overall, with bluntlypointed snout. Dorsal profile of head straight to slightly convex from tip of snout to vertical through posterior margin of orbit and broadly convex from that point to nape. Ventral profile of head slightly convex. Margin of snout in dorsal view broadly rounded. Postorbital margins of head slightly convex on each side from dorsal view. Enlarged jaw musculature very evident externally on dorsal and lateral surfaces of postorbital portion of head.

Opercular membrane attaching to isthmus only anterior of vertical through pectoral-fin insertion. Opercular opening moderately-elongate; extending anteroventral of pectoral-fin insertion by distance approximately equal to one-third of HL and extending dorsal of pectoral-fin insertion by distance equal to width of eye.

Eye situated on lateral surface of head; located entirely dorsal to horizontal extending through pectoral-fin insertion; eye visible in dorsal view, but not in ventral view, of head. Middle of orbit at approximately anterior 0.30 of HL. Eye diameter approximately one-third of snout length. Interorbital

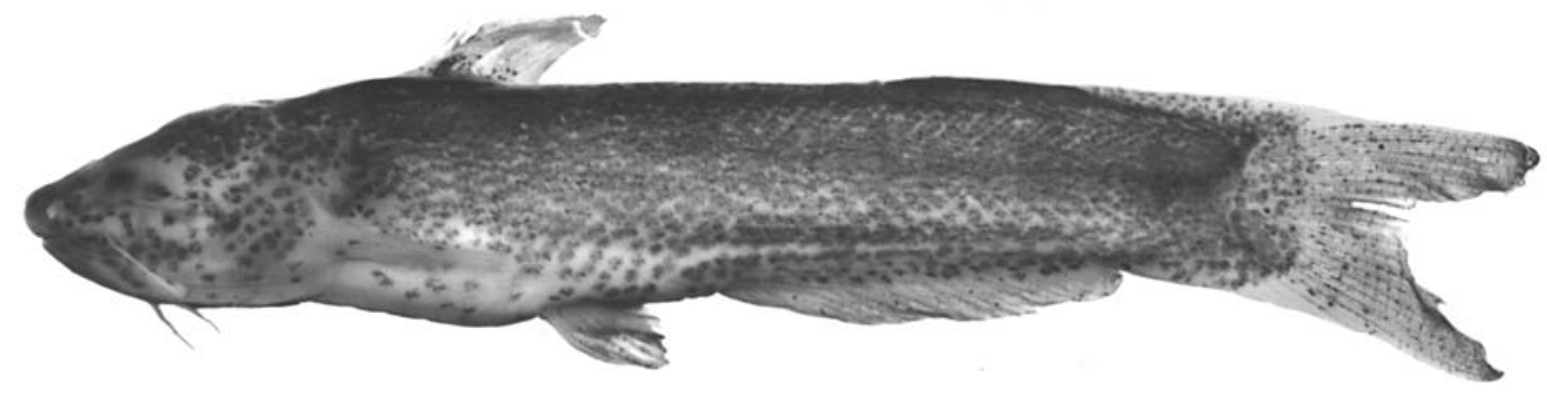

Fig. 7. Cetopsidium orientale, holotype of Pseudocetopsis orientale, MHNG 2621.040, 27 mm SL; Suriname, Brokopondo District, Mindrineti Kreek, close to mouth of Maykaboeka Kreek, Saramacca River basin, on Gros Rosevel Mining concession

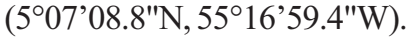


width approximately equal to distance from tip of snout to point lying within region between middle of eye and posterior margin of orbit. Anterior narial opening circular, surrounded by short, anteriorly-directed, tubular rim of skin. Opening of anterior nares located slightly dorsal of horizontal extending through maxillary-barbel origin and at, or slightly ventral of, horizontal running through tip of snout. Distance between anterior nares approximately equal to distance from tip of snout to middle of orbit. Posterior narial opening located on dorsal surface of head, situated dorsal to anterior one-third of orbit; narial opening rounded and nearly encircled by flap of skin, but with small gap posteriorly and flap highest anterolaterally.

Mouth subterminal; its width approximately 0.60 of HL. Margin of lower jaw gently rounded, its posterior limit reaching to vertical through middle of orbit. Premaxillary tooth patch in form of gently-arched band continuous across midline and with anterior margin convex and posterior margin concave and running in parallel to anterior margin. Teeth on premaxilla small, conical, sharply-pointed, and arranged in three regular rows of uniform-sized teeth across entire premaxilla. Vomerine teeth arranged in single, arched row, with distinct gap in tooth series at midline. Vomerine teeth conical, all of approximately uniform size, and with largest teeth in series approximately same size as largest teeth on premaxilla. Dentary teeth comparable in shape to, but slightly larger than, premaxillary teeth. Dentary dentition consisting of three irregular tooth rows medially that taper to one row laterally.

Maxillary barbel slender, its length approximately equal to distance from anterior margin of orbit to posterior margin of opercle, and slightly greater than three-fourths of HL; barbel origin located ventral to anterior margin of orbit. Medial mental barbel slightly shorter than lateral mental barbel, with latter shorter than maxillary barbel. Medial mental-barbel origin located along vertical through rictus. Lateral mental-barbel origin situated slightly posterior of vertical through medial mental-barbel origin. Tips of adpressed mental barbels extending to, or barely beyond, posterior margin of opercle.

Dorsal fin moderately large overall with length of dorsalfin base approximately $0.38-0.40$ of HL. Longest branched dorsal-fin ray, excluding distal filament present in mature males, equal in length to approximately two-thirds of HL. Dorsal-fin spinelet present, first dorsal-fin ray spinous for basal onehalf of length but flexible more distally, and with distal filament present in mature males. Distal margin of dorsal fin slightly convex, with first branched ray longest. Dorsal-fin origin located at approximately anterior $0.29-0.33$ of SL and along vertical extending through middle of adpressed pectoral fin. Tip of adpressed dorsal fin, excluding distal filament present on first ray in mature males, reaching to vertical through anterior margin of vent. Posterior most dorsal-fin ray with slight, basal, posterior, membranous attachment to body.

Caudal fin deeply-forked, symmetrical; tips of lobes rounded. Length of longest caudal-fin ray approximately two times length of middle fin rays.

Base of anal fin moderately long. Anal-fin origin located distinctly posterior of middle of SL and anterior of middle of
TL. Anal-fin margin nearly straight in most examined specimens, but convex in presumed mature males as evidenced by presence of distal filamentous first dorsal- and pectoral-fin rays. Posterior most anal-fin ray with slight, membranous attachment to body.

Pelvic fin small; distal margin slightly convex with middle fin rays longest. Pelvic-fin insertion located anterior to middle of SL and along vertical passing through posterior terminus of base of dorsal fin. Tip of adpressed pelvic fin extending past middle of SL and reaching anterior margin of vent. Medial most pelvic-fin ray with membranous attachment to body along basal one-half of its length.

Pectoral-fin length, excluding elongate filament on first ray in mature male specimens, slightly more than 0.60 of HL. Pectoral-fin margin distinctly convex, with middle ray longest. First pectoral-fin ray spinous with smooth margins, spine short with length slightly more than one-half that of first branched ray; ray prolonged as filament beyond margin of fin in presumed mature males.

Coloration in alcohol. Overall ground coloration of head and body pale and overlain with large, rounded, brown chromatophores. Dark pigmentation on head and body tends to be more concentrated dorsally. Expanded chromatophores blend together to form uniform brown cast on some to major portions of body in most specimens. Head with distinct, dark spots on regions anteroventral, ventral, posteroventral, and posterior to orbit. Ventral surface of abdomen and head pale except for scattered, dark, chromatophores on abdomen in some specimens and broad band of scattered, dark chromatophores extending from symphysis of lower jaw to opercle.

Dorsal fin pale with some dark pigmentation basally forming somewhat diffuse spot with dorsal margin in form of semicircle. Anal fin pale with scattered, dark chromatophores along basal portions of fin. Pelvic and pectoral fins pale. Caudal fin with few, scattered, dark chromatophores extending distally to at least middle of fin rays.

Maxillary barbel with scattered, dark pigmentation basally and pale distally. Mental barbels pale.

Coloration in life. LeBail et al. (2000: 147) provided a photograph of a live specimen of Cetopsidium orientale (identified therein as Pseudocetopsis cf. minutus), photographed in an aquarium immediately after capture. The overall dark pigmentation visible in the specimen in the photograph is comparable to that described above for preserved specimens, but the head, body, and fins of the photographed individual have an overlying silvery sheen that is absent in preserved individuals.

Sexual dimorphism. The presumed mature males of Cetopsidium orientale have filaments present on the distal portions of the first rays of the dorsal and pectoral fins and have the anal-fin margin slightly convex. Females and immature males of the species, in contrast, lack filaments on these fins and have a straight anal-fin margin. 
Distribution. Cetopsidium orientale is known from the coastal rivers of Suriname and French Guiana in the region from the Corantijn River along the border between Suriname and Guyana to the Fleuve Oyapock-rio Oiapoque along the French Guiana-Brazil border (Fig. 2). Given the presence of this species in the Surinamese tributaries of the Corantijn River, it is likely that is also occurs in the left bank tributaries to that river draining from Guyana. Similarly it is likely that $C$. orientale also occurs in the portions of the rio Oiapoque basin within Brazil. Material tentatively identified as this species originated in the rio Tocantins and rio Xingu (see "Remarks" below).

Ecology. The type locality of Cetopsidium orientale is a rainforest stream bordered by overhanging vegetation that at the time of collection of the type series had shallow $(40 \mathrm{~cm}$ deep), clear, slowly-moving water over a sand bottom with mud along the banks. The holotype and paratypes captured at that locality were living in holes and fissures in decaying branches submerged along the side of the stream. Mol et al. (2000: 430) characterize the Maykaboeka Creek as a low-gradient, second order drainage running through undisturbed rainforest. Non-type specimens from Degrad Florian in the Fleuve Iracoubo basin, French Guiana (MNHN 2002-1101) were captured in a stream approximately $3 \mathrm{~m}$ wide and 10-59 $\mathrm{cm}$ deep in clear, but slightly tea-colored, waters in areas with slow current densely shaded by the gallery forest. During the day $C$. orientale lies hidden in the sediment under leaves or roots (Philippe Keith, MNHN; pers. commun., 2002) in various localities within French Guiana. Observations of $C$. orientale by the senior author in the western limit of the species distribution in the Corantijn River along the Surinamese-Guyanese border indicate that the species lives in similar habitats in that region.

Remarks. In addition to the specimens reported on by Vari et al. (2003: 693), two lots of Cetopsidium from the rio Tocantins and rio Xingu basin agree with $C$. orientale in all examined features although having originated in localities lying considerable distances south of the previous known range of the species. One of these lots was collected by H. (=Harald) Schultz at an unspecified locality in the rio Araguaia basin sometime before 1961 at which time the specimens were catalogued into the collections of MNRJ. Schultz (1961: 65) documented his trip to Bananal Island (=Ilha do Bananal) in the rio Araguaia and it is possible that the specimens originated from that area. This area is proximate to the collecting site of the only known other sample of the species from outside of the Guianas (BMNH 1985.6.20.943-944) that originated in the southeastern tributaries of the upper rio Xingu system near the divide with the rio Araguaia basin and not far from the southern portions of the Ilha do Bananal (see LoweMcConnell, 1991, fig. 1). The latter specimens were reported on by Lowe-McConnell (1991:69) as Pseudocetopsis sp.

Material examined. 68 specimens (18-58 mm SL). Brazil. Mato
Grosso: Lakes near rio Suiá Missu (=Suiá-Miçu), BMNH 1985.6.20.943-944, 3 (21-23). rio Araguaia, MNRJ 9523, 4 (31.533). French Guiana. No specific locality, MNHN 2002-1103, 3 (37.5-38.5). Arataye River, Saut Parare ( $\left.4^{\circ} 03^{\prime} \mathrm{N}, 52^{\circ} 42^{\prime} \mathrm{W}\right), \mathrm{MNHN}$ 1994-0092, 1 (29.5). Crique Boulanger of Fleuve Comté (4³6’ N, $\left.52^{\circ} 19, \mathrm{~W}\right), \mathrm{MNHN} 2002-1099,2$ (38-38.5). Crique Balatée of Fleuve Maroni (529’ N, 5403'W), MNHN 2002-1098, 2 (43-49); MNHN 2002-1100, 1 (22). Degrad Florian of Fleuve Iracoubo $\left(5^{\circ} 29^{\prime} \mathrm{N}, 53^{\circ} 33^{\prime} \mathrm{W}\right)$, MNHN 2002-1101, 8 (24-44). Fleuve Oyapock [=rio Oiapoque], MNHN 2002-1102, 11 (40-58). Suriname. Kaiserberg River (approximately $3^{\circ} 03^{\prime} \mathrm{N}, 56^{\circ} 35^{\prime} \mathrm{W}$ ), FMNH 96268, 1 (25). Brokopondo District: Mindrineti Kreek, close to mouth of Maykaboeka Kreek, Saramacca River basin, on Gros Rosevel Mining concession ( $\left.5^{\circ} 07^{\prime} 08.8^{\prime \prime} \mathrm{N}, 55^{\circ} 16^{\prime} 59.4^{\prime \prime} \mathrm{W}\right)$, MHNG 2621.040, 1 (27, holotype of Pseudocetopsis orientale); MHNG 2621.044. 2 (22-22, paratypes of P. orientale); MHNG 2621.039, 4 (21-26, paratypes of $P$. orientale); MHNG 2626.013, 9 (18-27, paratypes of $P$. orientale); USNM 369732, 2 (21-24, paratypes of $P$. orientale); MNHN 2002.1625, 1 (26, paratype of $P$. orientale); NZCS F7048, 1 (23, paratype of $P$. orientale). Maykaboeka Creek, Gros Rosevel area, area of Golden Star Con-

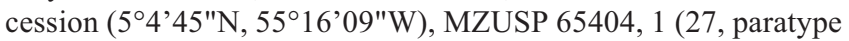
of $P$. orientale). Nickerie District: Stream near Avanavero, approximately 3 miles $(=4.8 \mathrm{~km})$ downstream of DeVis Falls (approximately $\left.4^{\circ} 48^{\prime} \mathrm{N}, 57^{\circ} 26^{\prime} \mathrm{W}\right)$, AMNH 54828,1 (22). Small stream on Lucie River camp to Paramaribo Road, $25 \mathrm{~km} \mathrm{~N}$ of Sisa Creek (approximately $3^{\circ} 34^{\prime} \mathrm{N}, 57^{\circ} 37^{\prime} \mathrm{W}$ ), AMNH 55001, 1 (32). Woodland stream, $0.5 \mathrm{~km}$ from Camp Mataway $\left(4^{\circ} 48^{\prime} \mathrm{N}, 57^{\circ} 43^{\prime} \mathrm{W}\right)$, USNM 226146, 2 (22-23). Stream near Camp Anjoemara (450’ N, 57²6'W), USNM 226147, 6 (18-24; 2 specimens, 20-21 mm, cleared and stained); MZUSP 79285, 1 (22; specimen cleared and stained). Stream at km 212 of Amotopo to Camp Geology Road, at Machine Park - Camp 212 (350’N, 57³4’W), USNM 226148, 1 (30).

\section{Cetopsidium pemon, new species}

Figs. 2, 8-9, Tables 2-8

Hemicetopsis minutus.-Taphorn \& García Tenía, 1991: 35 [Venezuela, Bolivar, lower río Caroni; possibly in part, see "Remarks"].

Diagnosis. Cetopsidium pemon differs from C. ferreirai in the degree of development of the first rays of the dorsal and pectoral fins (with distal filaments present in presumed mature males as indicated by the possession of a distinctly convex anal-fin margin versus absent in such specimens, respectively), the overall form of the head (profile of head distinctly pointed versus anteriorly rounded in lateral view, respectively), and in the length of the snout (approximately 3 times diameter of eye versus approximately 2 times diameter of eye, respectively). Cetopsidium pemon differs from C. minutum in the length of the pelvic fin (barely reaching, or falling short of, the vent versus reaching to the anal-fin origin, respectively). Cetopsidium pemon differs from C. morenoi in the form of the dark pigmentation on the body (small, point-like, scattered chromatophores located on the dorsal and lateral surfaces of the head versus large, stellate chromatophores present in those areas, respectively) and in the degree of develop- 


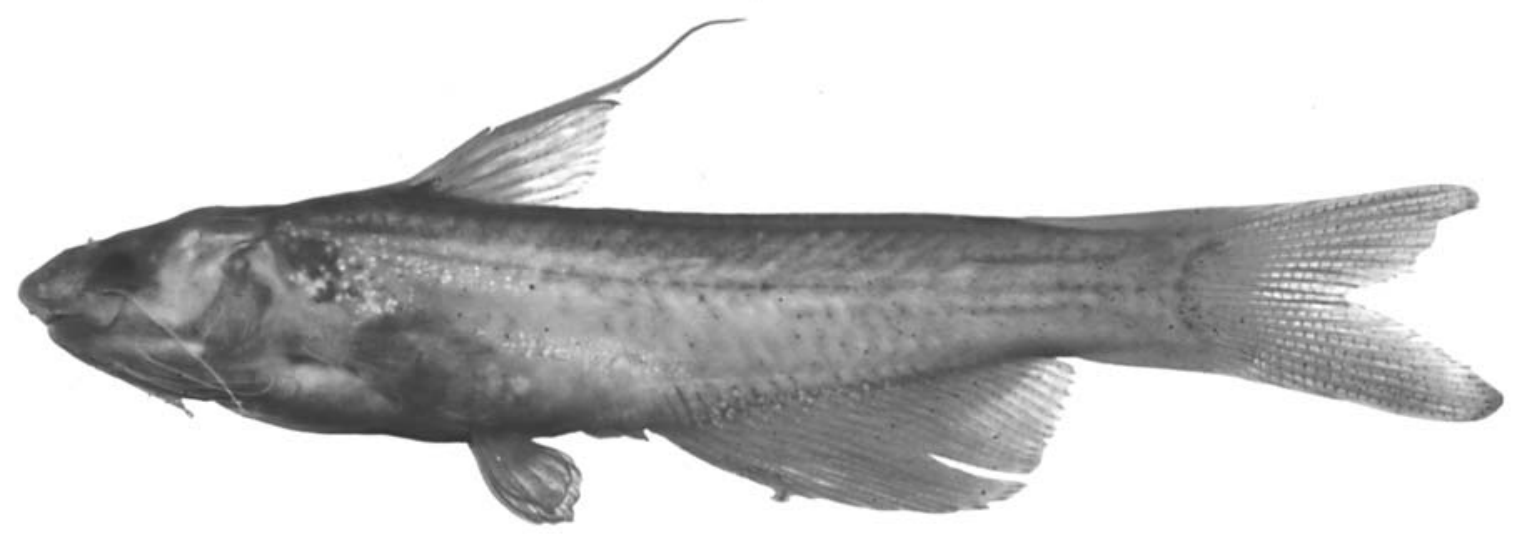

Fig. 8. Cetopsidium pemon, new species, holotype, mature male, MCNG 19475, 25 mm SL; Venezuela, Bolivar, río Caroni at mouth of río Claro $\left(7^{\circ} 54^{\prime} 45^{\prime \prime} \mathrm{N}, 63^{\circ} 02^{\prime} 35^{\prime \prime} \mathrm{W}\right)$.

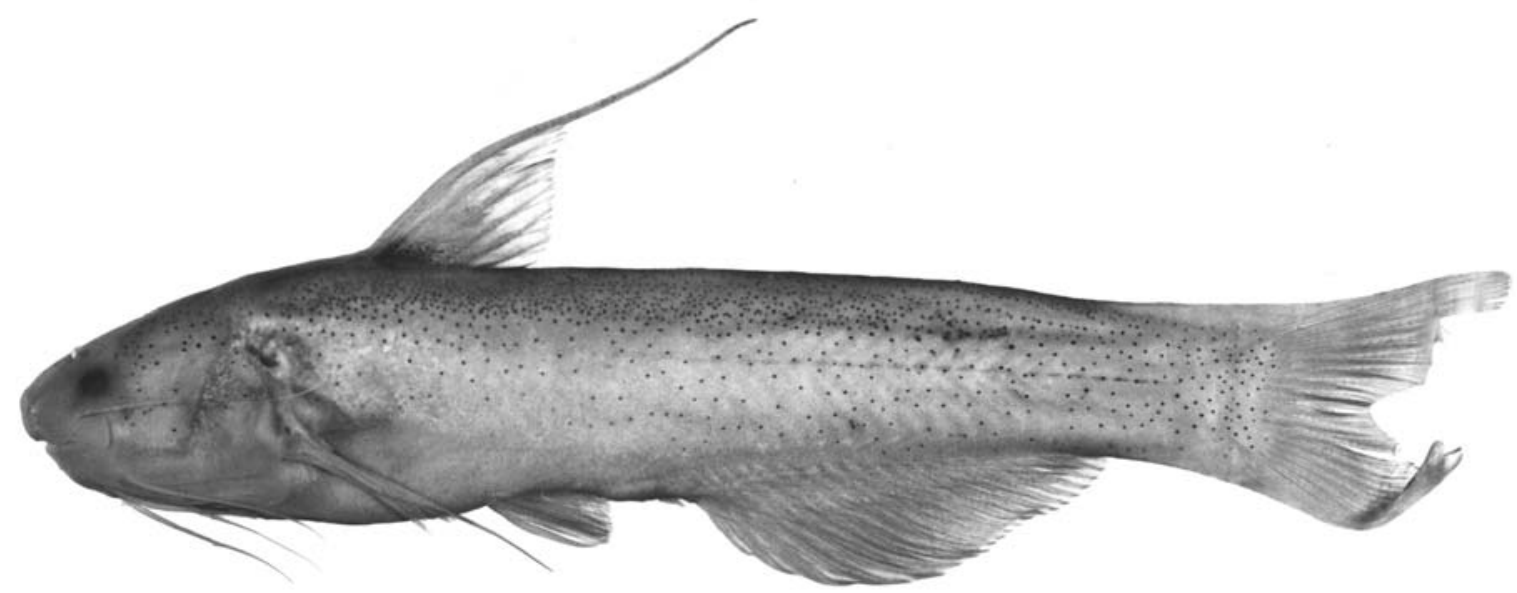

Fig. 9. Cetopsidium pemon, new species, mature male, AMNH 91375, 41 mm SL; Venezuela, Amazonas, río Mavaca.

ment of the adductor mandibular muscles (moderately-developed and not particularly obvious externally versus very well developed and distinctly obvious externally on dorsolateral portion of head, respectively). Cetopsidium pemon differs from $C$. orientale in the overall coloration (small, point-like, scattered chromatophores over the dorsal and lateral surfaces of the head and body versus large, stellate, dark chromatophores densely covering the dorsal and lateral surfaces of the head and body, respectively), and in the alignment of the dorsal and ventral profiles of the portion of the body posterior of the base of dorsal fin (converging posteriorly versus running in parallel, respectively). Cetopsidium pemon differs from $C$. roae in the position of the vent (located proximate to versus distinctly separated from the base of the anterior most anal-fin ray, respectively), in the alignment of the dorsal and ventral profiles of the portion of the body posterior of the base of dorsal fin (converging posteriorly versus running in parallel, respectively), and in the degree of development of the first rays of the dorsal and pectoral fins (with distal filaments present in presumed mature males as indicated by the possession of a distinctly convex anal-fin margin versus the apparent absent of these structures, respectively).
Description. Body moderately robust, somewhat compressed laterally anteriorly and becoming progressively more compressed posteriorly. Body depth at dorsal-fin origin approximately $0.22-0.24$ of SL, and slightly less than HL. Lateral line on body incomplete, unbranched, and midlateral; extending from vertical through pectoral-fin base posteriorly to region dorsal of base of anal fin, but falling short of caudal peduncle. Dorsal profile of body straight from nape to dorsal-fin origin and straight from dorsal-fin origin to caudal-fin base. Ventral profile of body slightly convex along abdomen, approximately straight, and slightly posterodorsally-inclined along base of anal fin. Caudal-peduncle depth approximately equal to, or slightly greater than, caudal-peduncle length.

Head in profile acutely triangular overall with bluntlypointed snout. Dorsal profile of head slightly convex from tip of snout to vertical through posterior margin of orbit and broadly convex from that point to nape. Ventral profile of head slightly convex. Margin of snout in dorsal view broadly rounded. Postorbital margins of head slightly convex on each side from dorsal view. Enlarged jaw musculature very evident externally on dorsal and lateral surfaces of postorbital portion of head. 
Opercular membrane attaching to isthmus only in area anterior of vertical through pectoral-fin insertion. Opercular opening moderately-elongate; extending anteroventral of pectoral-fin insertion by distance approximately equal to onehalf of HL and extending dorsal of pectoral-fin insertion by distance equal to width of eye.

Eye situated on lateral surface of head; located entirely dorsal to horizontal extending through pectoral-fin insertion; eye visible in dorsal view, but not in ventral view, of head. Middle of orbit located at approximately anterior one-fourth of HL. Eye diameter approximately one-half of snout length. Interorbital width approximately equal to distance from tip of snout to middle of orbit. Anterior narial opening circular, surrounded by short, anteriorly-directed, tubular rim of skin. Opening of anterior nares located slightly dorsal of horizontal extending through maxillary-barbel origin and at, or slightly ventral of, horizontal running through tip of snout. Distance between anterior nares approximately equal to distance from tip of snout to posterior margin of orbit. Posterior narial opening located on dorsal surface of head, situated dorsal to anterior one-third of orbit; narial opening nearly round and with flap of skin extending along anterior two-thirds of rim of aperture and flap highest anterolaterally.

Mouth subterminal; its width approximately $0.48-0.52$ of HL. Margin of lower jaw gently rounded, its posterior limit reaching to vertical through middle of orbit. Premaxillary tooth patch in form of gently-arched band, continuous across midline with anterior margin convex and posterior margin concave and running in parallel to anterior margin. Teeth on premaxilla small, conical, sharply-pointed, and arranged in three more or less regular rows of uniform-sized teeth across entire premaxilla. Vomerine teeth arranged in single, arched row with distinct gap in series at midline. Vomerine teeth stout, conical, and of approximately uniform size, but not substantially larger than teeth on premaxilla. Dentary teeth comparable in shape and size to premaxillary teeth. Dentary dentition consisting of three irregular rows medially that taper to one row laterally.

Maxillary barbel slender, its length approximately equal to distance from anterior margin of orbit to posterior margin of opercle, and slightly greater than three-fourths of HL; barbel origin located ventral to anterior margin of orbit. Medial mental barbel slightly shorter than lateral mental barbel, with latter shorter than maxillary barbel. Medial mental-barbel origin located along vertical through rictus. Lateral mental-barbel origin situated slightly posterior of vertical through medial mental-barbel origin. Tips of adpressed mental barbels extending to, or slightly past, posterior margin of opercle.

Dorsal fin moderately large overall with length of dorsalfin base approximately $0.36-0.41$ of HL. Longest branched dorsal-fin ray, excluding distal filament on first ray present in mature males, equal in length to approximately two-thirds of HL. Dorsal-fin spinelet present, first dorsal-fin ray spinous for basal one-half of length, flexible more distally, and prolonged as distal filament in at least some mature males. Distal margin of dorsal fin slightly convex, with first branched ray longest. Dorsal-fin origin located at approximately anterior
0.33 of SL and along vertical extending through middle of adpressed pectoral fin. Tip of adpressed dorsal fin, excluding distal filament of first ray present in mature males, reaching, or falling slightly short of, vertical through vent. Posterior most dorsal-fin ray with slight, basal, posterior, membranous attachment to body.

Caudal fin deeply-forked, symmetrical; tips of lobes rounded. Length of longest caudal-fin ray approximately two times length of middle fin rays.

Base of anal fin moderately long. Anal-fin origin located distinctly posterior of middle of SL and anterior of middle of TL. Anal-fin margin nearly straight in most examined specimens, but convex in presumed mature males as evidenced by possession of distal filaments on first rays of dorsal and pectoral fins. Posterior most anal-fin ray with slight, membranous attachment to body.

Pelvic fin small; distal margin slightly convex, with middle fin rays longest. Pelvic-fin insertion located anterior to middle of SL and along vertical through posterior terminus of base of dorsal fin. Tip of adpressed pelvic fin extending past middle of SL and barely reaching anterior margin of vent. Medial most pelvic-fin ray with membranous attachment to body along basal one-half of its length.

Pectoral-fin length, excluding distal filament on first ray of mature males, approximately one-half of HL. Pectoral-fin margin distinctly convex with middle ray longest. First pectoral-fin ray spinous with smooth margins; spinous portion of ray short with length slightly more than one-half that of first branched ray and prolonged as well-developed distal filament in mature males (Fig. 9).

Coloration in alcohol. Overall ground coloration of head and body pale and overlain with rounded, brown chromatophores. Dark pigmentation on head and body tends to be more concentrated dorsally but never forming intensely dark pigmentation. Ventral surface of abdomen and head pale or with few, widely-scattered, brown chromatophores. Lower lip with single row of dark chromatophores paralleling margin of lip.

Dorsal and anal fins pale, with scattered, dark chromatophores basally; pigmentation more developed on anterobasal portion of dorsal fin of some specimens. Caudal fin with widely scattered, tiny, dark chromatophores extending posteriorly to middle of fin in some, but not all, specimens. Pelvic and pectoral fins pale.

All barbels pale.

Sexual dimorphism. Presumed mature males of Cetopsidium pemon (Figs. 8,9) have the first ray of the dorsal and pectoral fins extending past the fin margin as a distinct filament contrary to the absence of such a prolongation on these rays in females and immature males. Mature males of the species also have the anal-fin margin broadly convex rather than straight as in females and immature males.

Distribution. Cetopsidium pemon is known from the río Caroni and the río Caura basins, southern tributaries of the 
río Orinoco in eastern Venezuela, the río Meta basin of the western portions of the río Orinoco system in eastern Colombia, and the upper portions of the rio Branco in northern Brazil (Fig. 2).

Etymology. The species name, pemon, is in reference to the Pemon, an Amerindian tribe whose traditional territories included the area of the type locality.

Remarks. Taphorn \& García Tenía (1991: 35) reported Hemicetopsis minutus (the Cetopsidium minutum of this study) from the río Claro system in the río Orinoco basin of Venezuela. Examination of at least some of the specimens that apparently served as the basis for that record demonstrated that they are rather Cetopsidium pemon. Lasso et al. (1990: 117) reported Hemicetopsis minutus (= Cetopsidium minutum herein) from the upper río Caroni in the Gran Sabana region of southeastern Venezuela. All specimens of Cetopsidium minutum examined in this study originated in the Essequibo River system of Guyana and the report of that species in the río Caroni basin by Lasso et al. (1990) may be based on specimens of $C$. pemon, an externally-similar species whose range includes at least portions of the río Caroni basin. The report of Pseudocetopsis sp. from the lower portions of the río Caura by Machado et al. (2003: 267) is also likely based on material of Cetopsidium pemon on the basis of the known distribution of that species.

One lot of four examined specimens that was collected in Bolivar state of Venezuela in the río Abacapa (FMNH 45708) is tentatively identified as Cetopsidium pemon based on external features. These specimens are, however, in somewhat poor condition; a situation that complicates direct comparisons with apparently conspecific samples. The río Abacapa sample demonstrates some apparent internal differences relative to other population samples of that species; however, an evaluation of the significance of these features must await the osteological examination additional material from the río Abacapa region.

Material examined. 33 specimens (20-42.6 mm SL). Holotype. Venezuela. Bolivar: río Caroni, at mouth of río Claro $\left(7^{\circ} 54^{\prime} 45^{\prime \prime} \mathrm{N}\right.$, 6302’35"W), D.C. Taphorn et al. 15 Mar 1988, MCNG 19475, 1, mature male (25). Paratypes. 12 specimens (23-41.5 mm SL). Venezuela. Bolivar: río Caroni at mouth of río Claro $\left(7^{\circ} 54^{\prime} 45^{\prime \prime} \mathrm{N}\right.$, $\left.63^{\circ} 02^{\prime} 35^{\prime \prime W}\right)$, MCNG 45650, 1 (23, formerly MCNG 19475, in part); USNM 375959, 1 (30, formerly MCNG 19475, in part); collected with holotype. Río Claro, east of Los Tanques ( $7^{\circ} 55^{\prime} 20^{\prime \prime N}$, 6306'05"W), D. C. Taphorn et al., 5 Mar 1988, MCNG 18422, 3 (27.5-41.5). Río Paragua, opposite mouth of río Carapo, at sand beach, C. J. Ferraris Jr. et al., AMNH 91188, 1 (24). Río Paragua off-shoot stream at Raudal Auraima ( $\left.6^{\circ} 17^{\prime} \mathrm{N}, 63^{\circ} 37^{\prime} \mathrm{W}\right)$, B. Stergios, 19 May 1987, MCNG 18113, 1 (40). Departamento Sucre, río Caura, above Caño La Prision ( $\left.7^{\circ} 00^{\prime} \mathrm{N}, 64^{\circ} 40^{\prime} \mathrm{W}\right)$, D. C. Taphorn et al., 1989, MCNG 21571, 3 (22-25); USNM 375960, 2 (22-23; formerly MCNG 21571, in part). Non-type specimens. 34 specimens (20-42.6 mm SL). Brazil. Roraima: Estrada between Fé (=Santa $\mathrm{Fe}$, approximately $3^{\circ} 46^{\prime} 59^{\prime \prime} \mathrm{N}, 59^{\circ} 35^{\prime} 59^{\prime \prime} \mathrm{W}$ ) and Esperança, INPA 16693 , 2. rio Mucajaí, Cachoeira Paredão (approximately $2^{\circ} 57^{\prime} \mathrm{N}$, $\left.61^{\circ} 27^{\prime} \mathrm{W}\right)$, INPA 16694, 2 (38-40); INPA 6505, 2 (41.4-42.6). Colombia. Meta: río Yucao, $13.5 \mathrm{~km}$ SE of Puerto Gaitan $\left(4^{\circ} 23^{\prime} \mathrm{N}\right.$, 72 04 'W), UF 26156, 17 (19-29; 2 specimens, 25-27 mm, cleared and stained). Río Manacías, sandbar on left (W) bank, $7 \mathrm{~km} \mathrm{SSE} \mathrm{of}$ Puerto Gaitan, AUM 28769, 1 (24). Venezuela. Amazonas: río Ocamo below Arata rapids ( $\left.3^{\circ} 08^{\prime} \mathrm{N}, 64^{\circ} 34^{\prime} \mathrm{W}\right), \mathrm{MCNG} 23748,1$ (31). río Orinoco at Isla Cupaven (approximately $3^{\circ} 05^{\prime} \mathrm{N}, 67^{\circ} 40^{\prime} \mathrm{W}$ ), FMNH 104482, 1 (37). Río Mavaca, 30 minutes upriver of base camp, at sand beach, AMNH 91375, 1 (41). Apure: Caño Potrerito at highway bridge between San Fernando de Apure and Puerto Paez $\left(6^{\circ} 33^{\prime} \mathrm{N}, 67^{\circ} 16^{\prime} \mathrm{W}\right)$, INHS 27681, 1 (21.5).

The following lot is tentatively identified as Cetopsidium pemon (see comments under "Remarks" above): Venezuela. Bolivar: Chimanta-tepui, río Abacapa, camp 1, $1300 \mathrm{~m}$ elevation (approximately $\left.5^{\circ} 18^{\prime} \mathrm{N}, 62^{\circ} 10^{\prime} \mathrm{W}\right)$, FMNH 45708,4 (23-30; 1 specimen, $27 \mathrm{~mm}$, cleared and stained).

\section{Cetopsidium roae, new species}

Figs. 2,10, Tables 2-8

Diagnosis. Cetopsidium roae differs from all of its congeners in the position of the vent (distinctly separated from the base of the anterior most anal-fin ray versus proximate to the base of the anterior most anal-fin ray, respectively). Cetopsidium roae further differs from C. ferreirai in the alignment of the dorsal and ventral profiles of the portion of the body posterior of the base of the dorsal fin (running in parallel versus converging, respectively). Cetopsidium roae differs from $C$. minutum in the length of the pelvic fin (tip of the adpressed fin distinctly separated from the base of the anterior most anal-fin ray versus proximate to the base of the anterior most anal-fin ray, respectively) and in the length of the pectoral fin (tip of fin falling distinctly short of the vertical through the pelvic-fin insertion versus reaching that line, respectively). Cetopsidium roae also differs from $C$. morenoi in the alignment of the dorsal and ventral profiles of the portion of the body posterior of the base of the dorsal fin (running in parallel versus converging posteriorly, respectively) and in the form of the dark pigmentation on the body (small, point-like, scattered chromatophores on the dorsal and lateral surfaces of head versus large stellate chromatophores in that region, respectively). Cetopsidium roae further differs from $C$. orientale in the overall coloration (small, point-like, scattered chromatophores distributed over the dorsal and lateral surfaces of head and body versus large, stellate, dark chromatophores densely covering the dorsal and lateral surfaces of the head and body, respectively). Cetopsidium roae also differs from $C$. pemon in the alignment of the dorsal and ventral profiles of the portion of the body posterior of the base of the dorsal fin (running in parallel versus converging posteriorly, respectively) and in the prolongations of the distal portions of the first rays of the dorsal and pectoral fins in mature males as indicated by the presence of a distinctly convex margin to the anal fin (prolongations apparently absent versus present, respectively). 


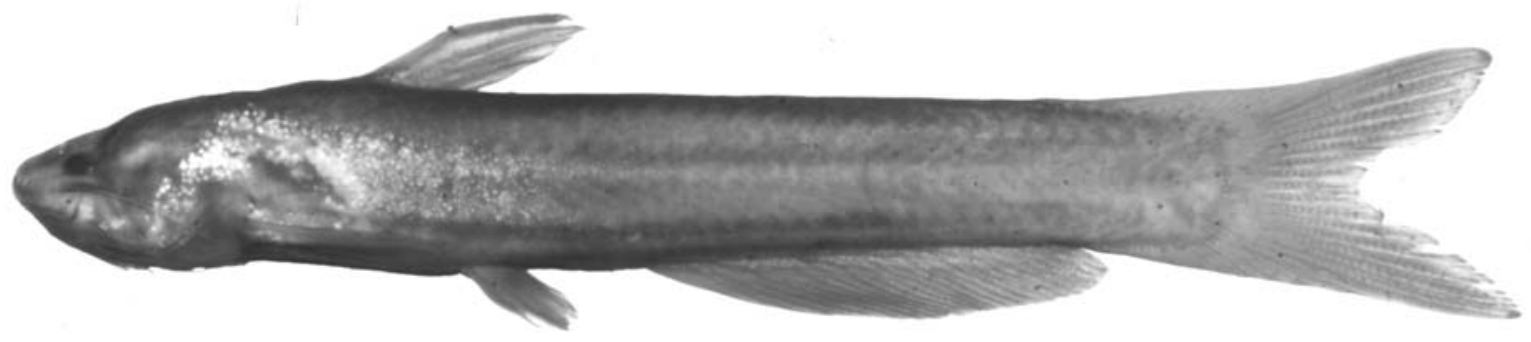

Fig. 10. Cetopsidium roae, new species, holotype, BMNH 1972.7.27:629-642, 34 mm SL; Guyana, Rupununi River, Karanambo $\left(3^{\circ} 45^{\prime} \mathrm{N}, 58^{\circ} 18^{\prime} \mathrm{W}\right)$.

Description. Body elongate, nearly cylindrical anteriorly and becoming progressively distinctly-compressed posteriorly. Body depth at dorsal-fin origin approximately $0.14-0.15$ of SL and approximately equal to postorbital length of head. Lateral line on body incomplete, unbranched, and midlateral; extending from vertical through pectoral-fin base posteriorly at least to region dorsal of base of anal fin, and in some individuals reaching vertical through anterior limit of caudal peduncle. Dorsal profile of body straight from nape to dorsalfin origin and straight from dorsal-fin origin to caudal-fin base. Ventral profile of body very slightly convex along abdomen, approximately straight, with base of anal fin straight and running nearly in parallel to horizontal axis of body. Caudal-peduncle depth slightly less than caudal-peduncle length.

Head in profile acutely triangular overall with bluntlypointed snout. Dorsal profile of head nearly straight from tip of snout to vertical through posterior margin of orbit and broadly convex from that point to nape. Ventral profile of head slightly convex. Margin of snout in dorsal view broadly rounded. Postorbital margins of head slightly convex on each side from dorsal view. Enlarged jaw musculature very evident externally on dorsal and lateral surfaces of postorbital portion of head.

Opercular membrane attaching to isthmus only anterior of vertical through pectoral-fin insertion. Opercular opening moderately-elongate; extending anteroventral of pectoral-fin insertion by distance approximately equal to one-third of HL and extending dorsal of pectoral-fin insertion by distance equal to width of eye.

Eye situated on lateral surface of head; located entirely dorsal to horizontal extending through pectoral-fin insertion; eye visible in dorsal view, but not in ventral view of head. Middle of orbit located at approximately anterior 0.40 of HL. Interorbital width approximately equal to distance from tip of snout to posterior margin of orbit. Anterior narial opening circular, surrounded by short, anteriorly-directed, tubular rim of skin. Opening of anterior nares located slightly dorsal of horizontal extending through maxillary-barbel origin and at, or slightly ventral of, horizontal running through tip of snout. Distance between anterior nares approximately equal to distance from tip of snout to anterior margin of orbit. Posterior narial opening located on dorsal surface of head, situated dorsal to anterior one-third of orbit; narial opening nearly round and with flap of skin extending along anterior twothirds of rim of aperture and flap highest anteromedially.

Mouth subterminal; its width approximately 0.50 of HL. Margin of lower jaw gently rounded, its posterior limit reaching to vertical through middle of orbit. Premaxillary tooth patch in form of gently-arched band, continuous across midline with anterior margin convex and posterior margin concave and running in parallel to anterior margin. Teeth on premaxilla small, conical, sharply-pointed, and arranged in three more or less regular rows of uniform-sized teeth across premaxilla. Vomerine teeth arranged in single, arched row with distinct gap in tooth series at midline. Vomerine teeth stout, conical, of approximately uniform size, and stouter but not distinctly longer than teeth on premaxilla. Dentary teeth comparable in shape and size to premaxillary teeth. Dentary dentition consisting of three irregular rows medially that taper to one row laterally.

Maxillary barbel slender, its length approximately equal to distance from anterior margin of orbit to posterior margin of opercle, and slightly greater than three-fourths of HL; barbel origin located ventral to anterior margin of orbit. Medial mental barbel approximately equal in length to lateral mental barbel, and shorter than maxillary barbel. Medial mental-barbel origin located along vertical through rictus. Lateral mentalbarbel origin situated slightly posterior of vertical through medial mental-barbel origin. Tips of adpressed mental barbels extending to, or slightly past, posterior margin of opercle.

Dorsal fin moderately large overall with length of dorsalfin base approximately 0.41-0.43 of HL. Length of longest branched dorsal-fin ray equal to slightly more than two-thirds of HL. Dorsal-fin spinelet present, first dorsal-fin ray spinous for basal one-half of its length, flexible more distally, and not prolonged beyond fin margin as distal filament. Distal margin of dorsal fin slightly convex, with first branched ray longest. Dorsal-fin origin located at approximately anterior 0.30 of SL and along vertical extending through posterior one-fourth to one-third of adpressed pectoral fin. Tip of adpressed dorsal fin falling slightly short of vertical through vent. Posterior most dorsal-fin ray with short posterior, membranous attachment to body basally.

Caudal fin deeply-forked, symmetrical; tips of lobes rounded. Length of longest caudal-fin ray approximately two times length of middle fin rays. 
Table 2. Number of specimens of the species of Cetopsidium with cited number of dorsal and pectoral-fin rays. Bold indicates value for holotype when examined.

\begin{tabular}{lcccccc}
\hline & \multicolumn{3}{c}{ Dorsal-fin Rays } & \multicolumn{3}{c}{ Pectoral-fin Rays } \\
& 4 & 5 & 6 & 6 & 7 & 8 \\
\hline C. ferreirai & & 1 & $\mathbf{4}$ & & $\mathbf{7}$ & \\
C. minutum & & & $\mathbf{2}$ & & 1 & \\
C. morenoi & & 3 & 50 & 15 & 31 & 1 \\
C. orientale & 2 & 3 & $\mathbf{3 5}$ & & $\mathbf{4 2}$ & 2 \\
C. pemon & & 6 & $\mathbf{2 4}$ & 8 & $\mathbf{2 2}$ & 1 \\
C. roae & & 1 & $\mathbf{1 9}$ & & $\mathbf{1 7}$ & \\
\hline
\end{tabular}

Table 3. Number of specimens of the species of Cetopsidium with cited number of branched anal-fin rays. Bold indicates value for holotype when examined.

\begin{tabular}{|c|c|c|c|c|c|c|c|}
\hline & \multicolumn{7}{|c|}{ Branched Anal-fin Rays } \\
\hline & 16 & 17 & 18 & 19 & 20 & 21 & 22 \\
\hline C. ferreirai & & & & 3 & 2 & 1 & \\
\hline C. minutum & & & 1 & 1 & & & \\
\hline C. morenoi & 1 & 1 & 2 & 2 & 1 & 1 & \\
\hline C. orientale & & & 2 & 8 & 5 & 4 & 1 \\
\hline C. pemon & & 1 & 2 & 11 & - & 1 & \\
\hline C. roae & & & & 2 & 1 & 1 & \\
\hline
\end{tabular}

Table 4. Number of specimens of the species of Cetopsidium with cited number of total anal-fin rays. Bold indicates value for holotype when examined.

\begin{tabular}{|c|c|c|c|c|c|c|c|c|}
\hline & \multicolumn{8}{|c|}{ Total Anal-fin Rays } \\
\hline & 20 & 21 & 22 & 23 & 24 & 25 & 26 & 27 \\
\hline C. ferreirai & & & & 4 & 3 & & & \\
\hline C. minutum & & & & 1 & 1 & & & \\
\hline C. morenoi & 1 & 6 & 9 & 19 & 10 & 3 & 3 & 1 \\
\hline C. orientale & & & & 9 & 6 & 15 & 10 & 2 \\
\hline C. pemon & & 4 & 7 & 9 & 5 & 2 & 4 & \\
\hline C. roae & & & 1 & 3 & 5 & 9 & 1 & \\
\hline
\end{tabular}

Table 5. Number of specimens of the species of Cetopsidium with cited number of preanal vertebrae. Bold indicates values for holotype when examined.

\begin{tabular}{lccccc}
\hline & \multicolumn{5}{c}{ Preanal Vertebrae } \\
& 13 & 14 & 15 & 16 & 17 \\
\hline C. ferreirai & 1 & $\mathbf{1}$ & 1 & 1 & \\
C. minutum & & & 1 & 1 & \\
C. morenoi & 2 & 18 & 23 & 5 & \\
C. orientale & 1 & 11 & $\mathbf{2 0}$ & 6 & 1 \\
C. pemon & 1 & 6 & $\mathbf{1 0}$ & 12 & \\
C. roae & & $\mathbf{9}$ & 8 & 2 & \\
\hline
\end{tabular}

Table 6. Number of species of the specimens of Cetopsidium with cited number of precaudal vertebrae. Bold indicates values for holotype when examined.

\begin{tabular}{lccccc}
\hline & \multicolumn{5}{c}{ Precaudal Vertebrae } \\
& 10 & 11 & 12 & 13 & 14 \\
\hline C. ferreirai & & 1 & - & $\mathbf{2}$ & 1 \\
C. minutum & & $\mathbf{2}$ & & & \\
C. morenoi & 14 & 10 & 20 & 6 & \\
C. orientale & 1 & $\mathbf{2 3}$ & 16 & 4 & \\
C. pemon & 2 & 5 & $\mathbf{1 6}$ & 6 & 2 \\
C. roae & 2 & $\mathbf{1 1}$ & 4 & 2 & \\
\hline
\end{tabular}

Table 7. Number of specimens of the species of Cetopsidium with cited number of caudal vertebrae. Bold indicates value for holotype when examined.

\begin{tabular}{lcccccc}
\hline & \multicolumn{7}{c}{ Caudal Vertebrae } \\
& 25 & 26 & 27 & 28 & 29 & 30 \\
\hline C. ferreirai & & 1 & $\mathbf{2}$ & 1 & & \\
C. minutum & & & & 1 & $\mathbf{1}$ & \\
C. morenoi & 1 & 13 & 28 & 6 & 2 & \\
C. orientale & & 1 & 10 & $\mathbf{1 3}$ & 16 & 3 \\
C. pemon & & 7 & 15 & 7 & 2 & \\
C. roae & & 2 & $\mathbf{9}$ & 7 & 1 & \\
\hline
\end{tabular}

Table 8. Numbers of specimens of the species of Cetopsidium with cited number of total vertebrae. Bold indicates value for holotype when examined

\begin{tabular}{|c|c|c|c|c|c|c|c|}
\hline & \multicolumn{7}{|c|}{ Total Vertebrae } \\
\hline & 36 & 37 & 38 & 39 & 40 & 41 & 42 \\
\hline C. ferreirai & & & & 1 & 3 & & \\
\hline C. minutum & & & & 1 & 1 & & \\
\hline C. morenoi & 4 & 12 & 4 & 19 & 5 & & \\
\hline C. orientale & & 1 & 1 & 12 & 22 & 6 & 1 \\
\hline C. pemon & & 2 & 8 & 9 & 7 & 5 & \\
\hline C. roae & & & 8 & 9 & 1 & 1 & \\
\hline
\end{tabular}

Base of anal fin moderately long. Anal-fin origin located distinctly posterior of middle of SL and anterior of middle of TL. Anal-fin margin nearly straight or slightly convex in all examined specimens. Posterior most anal-fin ray with slight, membranous attachment to body.

Pelvic fin proportionally small; distal margin slightly convex, with middle fin rays longest. Pelvic-fin insertion located anterior to middle of SL and along vertical through posterior terminus of base of dorsal fin. Tip of adpressed pelvic fin extending past middle of SL and vent, but falling far short of anterior limit of base of anal fin. Medial most pelvic-fin ray with membranous attachment to body along basal one-half of its length.

Pectoral-fin length approximately two-thirds of HL. Pectoral-fin margin distinctly convex with middle ray longest. First pectoral-fin ray spinous with smooth margins. Spine short with length slightly more than one-half that of first branched ray; ray not prolonged beyond fin margin as filament.

Coloration in alcohol. Overall ground coloration of head and body pale and overlain with rounded, brown chromatophores. Dark pigmentation on head and body tends to be more concentrated dorsally but never forming intensely dark pigmentation. Ventral surface of abdomen and head pale.

Dorsal and anal fins pale, with scattered, dark chromatophores basally. Caudal fin with widely scattered, tiny, dark chromatophores on fleshy basal part of fin and with rayed part of fin pale. Pelvic and pectoral fins pale.

All barbels pale.

Sexual dimorphism. No sexual dimorphism was apparent in the available population samples of Cetopsidium roae. 
Distribution. Cetopsidium roae is only known from the Rupununi region of southwestern Guyana (Fig. 2).

Etymology. The species name, roae, is in honor of the collector of all the known specimens of the species, Rosemary LoweMcConnell, known as Ro to her many colleagues and friends, in recognition of her contributions to our knowledge of the fishes of Guyana and many other regions of the world.

Material examined. 20 specimens (21-41 mm SL). Holotype. Guyana. Rupununi River, Karanambo ( $\left.3^{\circ} 45^{\prime} \mathrm{N}, 58^{\circ} 18^{\prime} \mathrm{W}\right), \mathrm{R}$. H. Lowe-McConnell, BMNH 1972.7.27.629, 1 (34). Paratypes. 19 specimens (21-41 mm SL). Guyana. Rupununi River, Karanambo $\left(3^{\circ} 45^{\prime} \mathrm{N}, 58^{\circ} 18^{\prime} \mathrm{W}\right)$, collected with holotype, BMNH 1972.7.27.630-642, 12 (21-34). Rupununi (exact locality unspecified), R. H. Lowe-McConnell, BMNH 1985.6.21.39-42, 4 (30-41).

\section{Genus Cetopsis Spix \& Agassiz}

Cetopsis Spix \& Agassiz, 1829: 8, 11 [type-species: Silurus coecutiens Lichtenstein, 1819, by subsequent designation by Bleeker, 1862b].

Hemicetopsis Bleeker, 1862a: 403 [type-species: Cetopsis candiru Spix \& Agassiz, 1829, by original designation].

Pseudocetopsis Bleeker, 1862a: 403 [type species: Cetopsis gobioides Kner, 1857, by original designation].

Bathycetopsis Lundberg \& Rapp Py-Daniel, 1994: 382 [type species: Bathycetopsis oliveirai Lundberg \& Rapp PyDaniel, 1994, by original designation].

Diagnosis. The combination of the absence of a spinelet associated with the dorsal fin, the absence of spines on the dorsal and pectoral fins, and the possession of a single row of teeth on the vomer distinguishes Cetopsis from the other genera in the Cetopsinae.

Remarks. The concept of Cetopsis utilized in this paper is considerably more encompassing than was the concept of the genus that was utilized in recent publications under which Cetopsis included only a single species, C. coecutiens (see "Systematic Overview" above).

\section{Cetopsis amphiloxa (Eigenmann, 1914)} Figs. 11, 12, Tables 9-15

Hemicetopsis amphiloxus Eigenmann, in Eigenmann et al., 1914: 14 [type locality: Creek near San Lorenzo, (río) Patia basin; also río San Juan at mouth of río Munguido and Quibdo].-Apolinar-Maria, 1914: 279 [listing of new species described in Eigenmann et al., 1914].-Eigenmann, 1920a: 13 [distribution]; 1920b: 10 [distribution].-Henn, 1928: 81 [type depository].-Gosline, 1945: 54 [listing].Ibarra \& Stewart, 1987: 44 [type depository].-Burgess, 1989: 292 [listing].-Mojica-C., 1999: 565 [in part, citation of species from Colombia, río Patia, río San Juan; not record of species from río Baudó].
Hemicetopsis amphiloxa.-Eigenmann, 1923:57, pl. 3, fig. 2 [redescription; Colombia, (río) Patia, (río) San Juan, and (río) Atrato basins].-Fowler, 1942: 131 [literature compilation].

Pseudocetopsis amphiloxa.-Schultz, 1944: 252 [in key].-Dahl, 1960b: 454 [comparisons with Pseudocetopsis baudoensis].-Barriga, 1991: 56 [Ecuador, Piso Tropical Oriental]; 1994b: 77, 80, 84 [Ecuador: río Mira, río Mataje, río Santiago; not cited material that originated in río Esmeraldas].--Evers \& Seidel, 2002: 741 [listing].-Vari \& Ferraris, 2003: 258 [in check list; distribution].

Pseudocetopsis cf. amphiloxa.-Roman-Valencia, 1990: 205 [Colombia, Choco; occurrence in ríos and quebradas; common name].

Diagnosis. Cetopsis amphiloxa can be distinguished from all of its congeners by the combination of the presence of an eye, the conical teeth on the vomer and dentary, the rounded posterior nares that is distinctly separated from the contralateral nares by a distance greater than the width of posterior nares, the absence of a dark humeral spot, the presence of very small rather than eye-sized or larger spots on the lateral and dorsal surfaces of the body, the lack of a concentration of dark pigmentation at the base of the dorsal fin, the lack of a band of dark pigmentation along the distal portion of the anal fin, the possession of 29 to 33 total anal-fin rays, 23 to 28 branched anal-fin rays, 10 to 12 precaudal vertebrae, 31 to 33 caudal vertebrae, 41 to 43 total vertebrae, 8 , or rarely, 9 pectoral-fin rays, and the lack of a concentration of dark pigmentation basally on the dorsal fin.

Description. Body slender, slightly laterally compressed anteriorly, becoming increasingly compressed posteriorly. Body depth at dorsal-fin origin approximately $0.21-0.23$ of SL and approximately equal to HL. Lateral line on body complete, unbranched, and midlateral; extending from vertical through pectoral-fin base onto hypural plate and terminating prior to posterior margin of hypural plate. Dorsal profile of body slightly convex from nape to dorsal-fin origin; straight from dorsal-fin origin to caudal-fin base. Ventral profile of body convex along abdomen, approximately straight, but posterodorsally slanted along base of anal fin. Caudal-peduncle depth approximately 1.25 times caudal-peduncle length.

Head triangular in lateral view and broadly rounded anteriorly. Dorsal profile of head nearly straight from tip of snout to posterior of nape. Ventral profile of head ranging from slightly convex to nearly straight. Profile of snout in dorsal view broadly rounded. Portion of head posterior of nares with lateral profiles diverging posteriorly. Dorsal surface of posterior portion of head without enlarged jaw musculature externally apparent.

Opercular membrane attaching to isthmus until point slightly anterior of vertical through pectoral-fin insertion. Opercular opening relatively wide; extending ventral of pectoral-fin insertion by distance approximately equal to distance from tip of snout to middle of eye and extending dorsal of pectoral-fin insertion by distance approximately equal to snout length. 


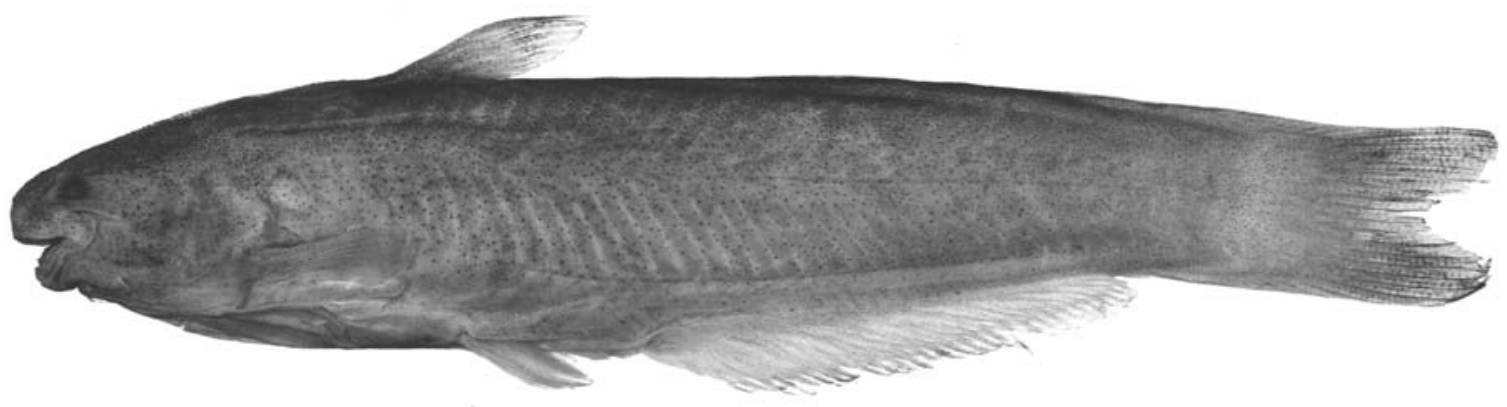

Fig. 11. Cetopsis amphiloxa, holotype of Hemicetopsis amphiloxus, FMNH 56519, 65 mm SL; Colombia, Choco, río Patía basin, creek near San Lorenzo (approximately $2^{\circ} 13^{\prime} \mathrm{N}, 78^{\circ} 40^{\prime} \mathrm{W}$ ).

Eye situated on lateral surface of head; located entirely dorsal to horizontal extending through pectoral-fin insertion; eye visible in dorsal view, but not in ventral view, of head. Middle of orbit at slightly less than anterior one-third of HL. Eye diameter approximately one-half of snout length. Interorbital width approximately equal to distance from tip of snout to posterior margin of orbit. Anterior narial opening circular, surrounded by short, anteriorly-directed, tubular rim of skin. Opening of anterior nares located at horizontal extending through tip of snout and slightly dorsal to horizontal running through maxillary-barbel origin. Distance between anterior nares greater than distance from anterior to posterior nares, and approximately equal to distance from tip of snout to middle of eye. Posterior narial opening located near dorsal profile of head; opening rounded, with anterior one-half of aperture bordered by flap of skin. Distance between posterior nares slightly less than distance between anterior nares.

Mouth inferior; its width approximately 0.25 to 0.50 of HL. Margin of lower jaw broadly rounded, its posterior limit falling just short of vertical through middle of eye. Premaxillary tooth patch elongate and crescentic, continuous across midline; anterior margin convex, posterior margin concave. Premaxillary teeth of moderate size, conical, and sharply-pointed, with teeth arranged in two rows medially and reduced to one row on lateral most portion of tooth patch. Teeth of inner most premaxillary tooth row notably larger than those of outer row. Vomerine teeth arranged in one anteriorly-convex row. Vomerine teeth bluntly conical and approximately equal in size to largest premaxillary teeth. Dentary with single row of sharply-pointed, conical teeth; teeth largest medially, with symphyseal teeth somewhat larger than largest premaxillary teeth.

Maxillary barbel slender, its length greater than distance from tip of snout to posterior margin of orbit and nearly equal to one-half of HL; barbel origin located ventral of middle of orbit. Mental barbels approximately equal in size and length to maxillary barbel and to each other. Medial mental-barbel origin located along vertical through posterior margin of orbit. Lateral mental-barbel origin located slightly posterior of vertical through posterior margin of orbit. Tips of adpressed mental barbels falling short of posterior margin of opercle.

Dorsal fin moderately large overall with length of base of dorsal fin approximately $0.32-0.34$ of HL. Longest dorsal-fin ray equal in length to postorbital portion of head. Dorsal-fin spinelet absent. First dorsal-fin ray not spinous, and with distal filament absent in limited available sample of specimens. Distal margin of dorsal fin nearly straight, with first ray longest. Dorsal-fin origin located at approximately anterior one-third of SL and along vertical through distal one-third of adpressed pectoral fin. Tip of adpressed dorsal fin reaching to vertical through tip of adpressed pelvic fin. Posterior most dorsal-fin ray without posterior, membranous attachment to body.

Caudal fin shallowly-forked, symmetrical; tips of lobes slightly rounded. Length of longest caudal-fin ray 1.5 times length of middle fin rays.

Base of anal fin long, approximately 0.4 of SL. Anal-fin origin located slightly posterior of middle of SL. Anal-fin margin nearly straight, with limited available population sample not demonstrating sexual dimorphism of distal margin of fin present in many members of Cetopsinae. Posterior most unbranched anal-fin ray longest, with length of subsequent rays gradually decreasing. Posterior most anal-fin ray with posterior, membranous attachment to body for basal one-half of its length.

Pelvic fin moderate, distal margin convex, first and second branched rays longest. Pelvic fin completely in advance of middle of SL, with origin of fin located along vertical through posterior one-half of base of dorsal fin. Tip of adpressed pelvic fin reaching to vent. Medial most pelvic-fin ray with membranous attachment to body for basal two-thirds of its length.

Pectoral-fin length approximately three-quarters of HL. Pectoral-fin margin convex, with second and third branched rays longest. First pectoral-fin ray not spinous and with limited available sample lacking distal filament present in some members of Cetopsinae.

Coloration in alcohol. Scattered, dark pigmentation consisting primarily of very small spots distributed over dorsal and lateral portions of head and body. Abdomen and underside of head virtually without dark pigmentation. Skin overlying lower jaw with some scattered, dark pigmentation, but with pigmentation less intense than that of upper jaw. 


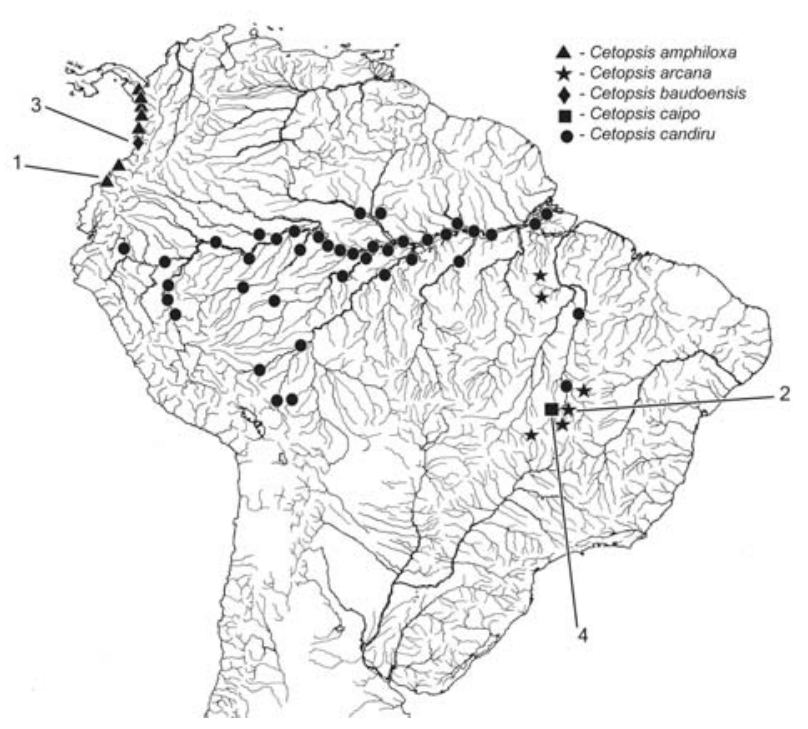

Fig. 12. Map of central and northern South America showing geographic distribution of Cetopsis amphiloxa $(1=$ holotype locality of Hemicetopsis amphiloxus), Cetopsis arcana (2 = holotype locality), Cetopsis baudoensis ( 3 = holotype locality of Pseudocetopsis baudoênsis), Cetopsis caiapo (4 = holotype locality), and Cetopsis candiru (type locality inexact = rivers of Equatorial Brazil) (some symbols represent more that one locality and/or lot of specimens).

Dorsal, anal, and caudal fins with scattered, dark pigmentation over lateral surfaces except along distal margins of fins. Pelvic fin with only few, scattered, dark chromatophores. Pectoral fin with scattered, dark pigmentation on basal onehalf of dorsal surface of anterior fin rays.

Barbels light overall and with scattered, dark chromatophores.

Sexual dimorphism. The sexual dimorphism in the dorsal, pectoral, and anal fins present in many members of the Cetopsinae was not apparent in the limited number of examined specimens of Cetopsis amphiloxa.

Distribution. Cetopsis amphiloxa is known from the northern portions of the río San Juan basin and southern sections of the adjoining río Atrato basin, both in western Colombia, the río Patia basin of southwestern Colombia, and the rivers of northwestern Ecuador (Fig. 12).

Common name. Colombia, río Atrato: "Tariba," "Baboso" (Roman-Valencia, 1990: 205).

Remarks. In his summary treatment of the freshwater fishes of northwestern Ecuador, Barriga (1994b: 77, 80, 84) reported Pseudocetopsis amphiloxa from the río Esmeraldas, río Mira, río Mataje, and río Santiago. All samples of the Cetopsinae from the río Esmeraldas basin examined during this study proved to be Paracetopsis esmeraldas and we consequently tentatively consider the Barriga (1994b) reference of Pseudocetopsis amphiloxa from that river system to refer to Paracetopsis esmeraldas. Two of the three specimens of the Cetopsinae examined during this study (MEPN 1525, MEPN 1526) that originated in the río Santiago, the river system to the north of the río Esmeraldas were Cetopsis amphiloxa and represent the southern most records for that species. The third examined specimen of the Cetopsinae from that river basin (CAS 162438) is Paracetopsis esmeraldas and that sample represents the northern record for this species and the only examined specimen of that species originating from outside the río Esmeraldas basin. The occurrence of both Cetopsis amphiloxa and Paracetopsis esmeraldas at relatively closely situated localities in the río Santiago makes that basin the only river system on the western slopes of the Andes where two species of the Cetopsinae apparently live in sympatry. Although we were unable to examine the specimens that served as the basis for Barriga's (1994b) citation of Pseudocetopsis amphiloxa from the río Mira and río Mataje, both of those river systems lie within the known range of Cetopsis amphiloxa and these records are tentatively assumed to be based on specimens of that species.

Roman-Valencia (1990: 205) reported Pseudocetopsis cf. amphiloxa from the central portions of the río Atrato basin, an area somewhat to the north of the most northerly locality for the specimens of Cetopsis amphiloxa examined in this study. We tentatively consider Roman-Valencia's report to be a record of Cetopsis amphiloxa in so far as the only other member of the Cetopsinae known to occur in the río Atrato basin is Cetopsis fimbriata. Cetopsis fimbriata is, however, apparently endemic to the río Nercua, a tributary of the río Truando that empties into the río Atrato further to the north than the region sampled by Roman-Valencia (1990).

Cetopsis amphiloxa has the most extensive distribution of any Trans-Andean member of the Cetopsinae, being known from samples that were collected in the area ranging from the río Cayapas basin of northwestern Ecuador to the upper portions of the río Atrato system in northwestern Colombia, albeit with a major gap in the known distribution of the species between the río Patia and río San Juan basins in western Colombia. The river systems between the río Patia and río San Juan systems are poorly sampled ichthyologically and, with one exception, the limited available samples of $C$. amphiloxa (eight specimens from eight localities) fail to demonstrate any notable differences across that region. The only exception is the single examined specimen from Quibdo in the upper río Atrato basin (CAS 77028, paratype of Hemicetopsis amphiloxus) that has nine pectoral-fin rays contrary to the eight pectoral-fin rays that are present in all other examined specimens of $C$. amphiloxa. The examination of additional populations from across the apparent range of $C$. amphiloxa is necessary to determine whether the variation in the number of pectoral-fin rays within what is herein considered to be that species is perhaps indicative of the presence of more than one species within that material or simply represents intraspecific variation. 


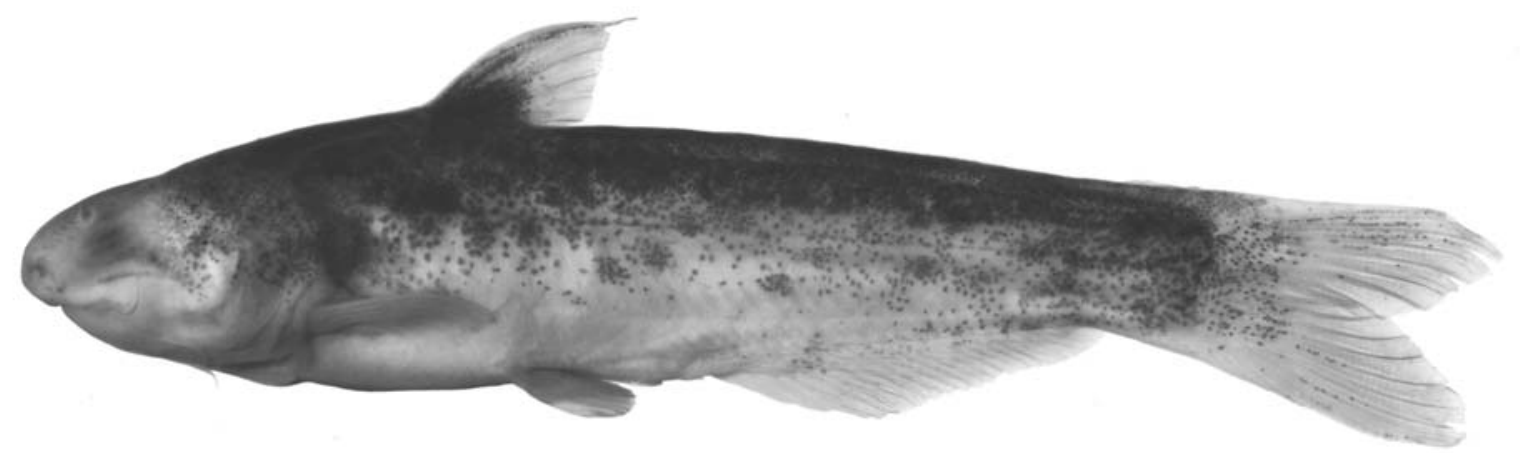

Fig. 13. Cetopsis arcana, new species, holotype, MZUSP 58637, 76 mm SL; Brazil, Goiás, São Domingos, Parque Estadual de Terra Ronca, Boca da Lapa de Bezerra (13³2’43"S, 46²2’35"W).

Material examined. 8 specimens $(22-188 \mathrm{~mm} \mathrm{SL})$. Colombia. Choco: río Condoto (approximately $5^{\circ} 06^{\prime} \mathrm{N}, 76^{\circ} 42^{\prime} \mathrm{W}$ ), BMNH 1914.5.18.49, 1 (64). Río San Juan, at Cabeceras ( $\left.4^{\circ} 18^{\prime} \mathrm{N}, 77^{\circ} 09^{\prime} \mathrm{W}\right)$, NRM 10679, 1 (65). Río San Juan at mouth of río Munguido (5'43'N, 76 $42^{\circ}$ 'W), CAS 77027, 1 (79, paratype of Hemicetopsis amphiloxus). Río Patía basin, creek near San Lorenzo (approximately $\left.2^{\circ} 13^{\prime} \mathrm{N}, 78^{\circ} 40^{\prime} \mathrm{W}\right)$, FMNH 56519, 1 (65, holotype of Hemicetopsis amphiloxus). Quibdo, town at junction of río Quito and río Atrato (5'42’N, 76³ ' W), CAS 77028, 1 (42, paratype of Hemicetopsis amphiloxus; formerly IU 13109). Raspadura ( $5^{\circ} 16^{\prime} \mathrm{N}$, $76^{\circ} 42^{\prime}$ W), FMNH 55170, 1 (22). Ecuador. Esmeraldas: Estero los Indios, Vargas Torres (latter locality at $1^{\circ} 14^{\prime} \mathrm{N}, 79^{\circ} 01^{\prime} \mathrm{W}$ ), MEPN 1525, 1 (45). Estero Sabalera, $600 \mathrm{~m}$ from Campamento del MAG, La Chiquita, along highway to Ricaurte, tributary to río Bogotá, río Santiago basin (1 $\left.1^{\circ} 13^{\prime} 47^{\prime \prime} N, 78^{\circ} 45^{\prime} 19^{\prime} \mathrm{W}\right)$, MEPN 1526, 1 (77; specimen cleared and stained).

\section{Cetopsis arcana, new species}

Figs. 12, 13, Tables 9-15

Pseudocetopsis plumbeus [not of Steindachner, 1882].Bichuette \& Trajano, 2003: 1105, 1108 [Brazil, São Domingos karst region of upper rio Tocantins basin; presence in epigean and subterranean water systems].

Diagnosis. Cetopsis arcana can be distinguished from all of its congeners by the combination of the presence of an eye, the conical teeth on the vomer and dentary, the rounded posterior nares that is distinctly separated from the contralateral nares by a distance greater than the width of posterior nares, the presence of a dark humeral spot except in some individuals that lack a pattern consisting of dark pigmentation on the pectoral and pelvic fin other than for a thin, clear margin, the presence of a posteriorly-rounded, variably-developed, bilobed patch of dark pigmentation at the base of the caudal fin, the presence of a spot of dark pigmentation on the base of the dorsal fin with prominent dark pigmentation along the membrane behind the first ray of the dorsal fin, the possession of typically 42 or 43 total vertebrae (41 vertebrae in only one individual), the presence of a distinct demarcation between the dark pigmentation on the dorsal and dorsolateral surfaces of the body versus more ventral regions, and the limitation of eye-size or larger dark spots on the lateral surface of the body to the region dorsal of the horizontal extending through the ventral margin of the caudal peduncle.

Description. Body somewhat deep, slightly-compressed laterally anteriorly, becoming increasingly compressed posteriorly. Body depth at dorsal-fin origin slightly less than HL and slightly greater than 0.27 of SL. Lateral line on body complete, unbranched, and midlateral; extending from vertical through pectoral-fin base to hypural plate. Dorsal profile of body slightly convex and distinctly inclined from nape to dorsal-fin origin; nearly straight from dorsal-fin origin to caudal-fin base. Ventral profile of body convex along abdomen, approximately straight, but posterodorsally slanted along base of anal fin. Caudalpeduncle depth slightly less than caudal-peduncle length.

Head coming to blunt point anteriorly and triangular overall in lateral view. Dorsal profile of head convex from tip of snout to vertical through posterior nares, straight from nares to vertical through middle of eye and convex from that point to posterior of nape. Ventral profile of head gently convex. Profile of snout in dorsal view triangular overall but rounded at tip. Portion of head posterior of nares with lateral profiles diverging from dorsal view. Dorsal surface of posterior portion of head with enlarged jaw musculature externally apparent.

Opercular membrane attaching to isthmus until point slightly anterior of vertical through pectoral-fin insertion. Opercular opening moderately wide; extending ventral of pectoral-fin insertion by distance approximately equal to snout length and extending dorsal of pectoral-fin insertion by distance approximately equal to two-thirds of snout length.

Eyes situated on lateral surface of head; located entirely dorsal to horizontal extending through pectoral-fin insertion; eye visible in dorsal view, but not in ventral view, of head. Middle of orbit at slightly less than anterior one-fourth of HL. Eye diameter approximately one-third of snout length. Interorbital width approximately equal to distance from tip of snout to posterior margin of orbit. Anterior narial opening circular, surrounded by short, anteriorly-directed, tubular rim of skin. Opening of anterior nares located along horizontal extending through point slightly ventral of tip of snout and along running through maxillary-barbel origin. Distance between anterior nares ap- 
proximately equal to distance from anterior to posterior nares, and approximately equal to snout length. Posterior narial opening moderately large and located near dorsal profile of head and anterior to vertical through anterior margin of eye; opening rounded, with anterior two-thirds of aperture bordered by flap of skin and flap highest anteriorly. Distance between posterior nares slightly less than distance between anterior nares.

Mouth subterminal; its width approximately one-half of HL. Margin of lower jaw broadly rounded, its posterior extent reaching slightly beyond vertical through posterior margin of eye. Premaxillary tooth patch elongate, continuous across midline; anterior margin convex, posterior margin concave and running in parallel to anterior margin. Teeth on premaxilla of moderate size, conical, and sharply-pointed, with teeth arranged in four relatively regular rows medially and three relatively regular rows laterally. Teeth of anterior tooth row much smaller than teeth of remaining tooth rows, all of which are of similar size. Vomerine teeth arranged in one continuous, anteriorly-convex row. Vomerine teeth bluntly conical and distinctly larger than premaxillary teeth. Dentary dentition consisting of four irregular rows of teeth medially and reduced to two rows laterally and finally one row posteriorly. Teeth of outermost dentary tooth row distinctly smaller than teeth in other rows.

Maxillary barbel slender, its length distinctly greater than distance from tip of snout to posterior margin of orbit and nearly equal to one-half of HL; barbel origin at vertical through middle of eye. Mental barbels approximately equal in size and length and as long as maxillary barbel. Medial mental-barbel origin located along vertical through posterior margin of orbit. Lateral mental-barbel origin situated slightly posterior of vertical through posterior margin of orbit. Tips of adpressed mental barbels falling short of posterior margin of opercle.

Dorsal fin moderately large overall with length of dorsalfin base approximately $0.45-0.48$ of HL and slightly longer than distance from tip of snout to posterior margin of eye. Longest dorsal-fin ray, excluding distal filament on first ray, approximately equal to one-fifth of SL. Dorsal-fin spinelet absent. First dorsal-fin ray not spinous, with short, distal, filament in females and immature males and with longer filament in mature males. Distal margin of dorsal fin straight to distinctly concave, with first ray longest. Dorsal-fin origin located at approximately anterior one-third of SL and along vertical through middle of adpressed pectoral fin. Tip of adpressed dorsal fin, without filament, reaching to vertical through tip of adpressed pelvic fin. Posterior most dorsal-fin ray without posterior, membranous attachment to body.

Caudal fin moderately-forked, symmetrical; tips of lobes slightly rounded. Length of longest caudal-fin ray slightly more than 1.5 times length of middle fin rays.

Base of anal fin moderate, approximately $0.30-0.32$ of SL. Anal-fin origin located distinctly posterior of middle of SL but anterior to middle of TL. Anal-fin margin straight in juveniles and presumed females, with posterior most unbranched anal-fin ray longest and subsequent rays gradually becoming shorter. Posterior most anal-fin ray with posterior, membranous attachment to body for basal one-fourth of its length.
Anal-fin margin in mature males convex for anterior two-thirds and straight posteriorly, with rays along straight section slightly shorter than those of immediately preceding portion of fin.

Pelvic fin moderate, its distal margin slightly convex, with first branched ray longest. Tip of adpressed pelvic fin extending distinctly beyond middle of SL. Origin of pelvic fin located along vertical through posterior terminus of base of dorsal fin. Tip of adpressed pelvic fin barely reaching vent. Medial most pelvic-fin ray with membranous attachment to body for basal two-thirds of its length.

Pectoral-fin length approximately two-thirds of HL. Margin of branched pectoral-fin rays straight along four lateral most rays with first ray longest and concave medially. First pectoral-fin ray not spinous and with distal filament in all specimens, but with filament proportionally longer in adult males.

Coloration in alcohol. Body very dusky dorsally and typically becoming abruptly pale in region of lateral line. Ventral half of body with irregular, dark, blotches of size slightly smaller than eye. Irregular blotches present in most individuals obscured in intensely pigmented specimens by overall darker pigmentation. Some exceptionally intensely pigmented specimens with dark pigmentation on ventrolateral portion of body nearly as well-developed as coloration on dorsal surface of body. Some specimens with distinct humeral spot. Ventral surface of abdomen pale in all specimens. Head dark dorsally and either pale or noticeably lighter ventrally. Dorsal surface of snout dark at least as far ventrally as horizontal extending through anterior nares, with dark pigmentation in some specimens extending anteriorly to dorsal margin of upper lip. Triangular region between upper lip and tip of snout pale or noticeably lighter than remainder of snout. Eyes with horizontally-elongate, ovoid, pale patch extending from vertical through anterior nares to vertical through lateral mental-barbel origin; more lightly-pigmented region less obvious in overall distinctly-darker individuals. Ventral surface of head pale or with some widely scattered spots of dark pigmentation.

Dorsal fin dark on basal one-half of anterior rays and basal one-third of posterior rays. Distal portion of dorsal fin clear or dusky, with abrupt, but irregular transition between dark and clear regions. Anterior margin of anal fin pale to base; with interradial membrane between first and second anal-fin rays dusky nearly to distal margin of fin. Dark, diffuse, pigmentation on anal fin extending along entire length of base and continuing onto fin rays to variable extent. Darkly-pigmented specimens with only distal margin of anal fin pale. Caudal fin with irregular, dark pigmentation forming bilobed patch of dark pigmentation at base of fin. Dark, bilobed patch variably obscured in darkly pigmented specimens. Caudal fin with scattered, dark pigmentation along at least basal portions of rays, with small spots of dark pigmentation extending nearly to distal margin of fin in darkly-pigmented specimens. Pelvic and pectoral fins generally pale, with scattered, dark chromatophores at base of fins and on dorsal surface of interradial membrane between first and second rays.

Barbels dusky basally and becoming pale distally. 


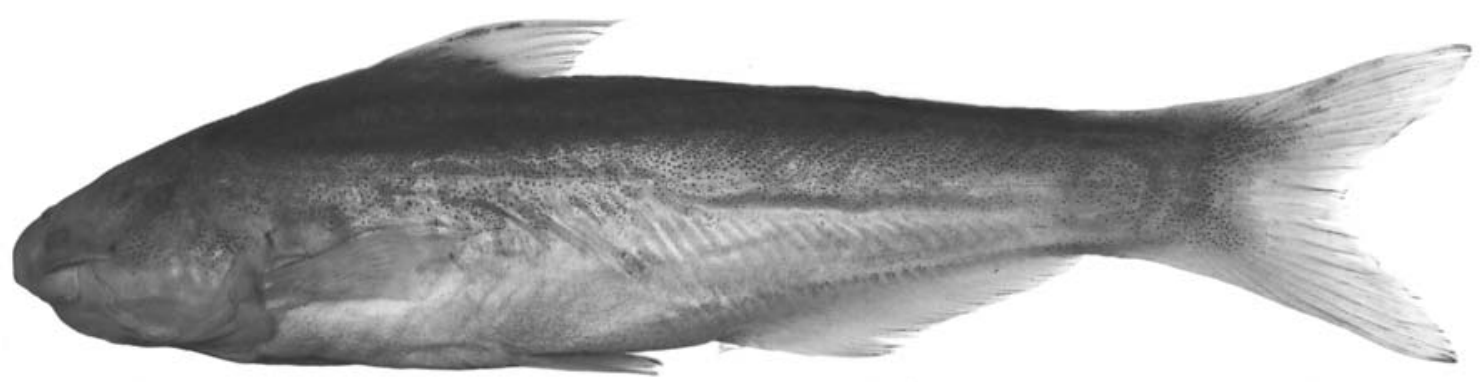

Fig. 14. Cetopsis baudoensis, NRM 27738, 98 mm SL; Colombia, Choco, río Baudó drainage, Boca de Pepé, various tributaries and river close to village $\left(5^{\circ} 04^{\prime} \mathrm{N}, 77^{\circ} 03^{\prime} \mathrm{W}\right)$.

Sexual dimorphism. Mature males of Cetopsis arcana have the distal filament on the first rays of the dorsal and pectoral fins somewhat more developed than those present in females and immature males. The anal-fin margin in males of the species is convex overall with abruptly shorter posterior rays, contrary to being straight in females and immature males.

Distribution. Cetopsis arcana is only known from middle and upper portions of the rio Tocantins basin (Fig. 12).

Etymology. The species name, arcana, from the Latin for secret or hidden, refers to the occurrence of the species in sinkholes in the type region.

Ecology. The type series of Cetopsis arcana was collected in a karstic region of the upper rio Tocantins basin in both epigean and subterranean waters (Bichuette \& Trajano, 2003: 1105, 1108; species cited therein as Pseudocetopsis plumbeus).

Remarks. One relatively small specimen with a reported locality of Brazil, Roraima, rio Oraricao, Igarapé Canao (approximately $4^{\circ} 46^{\prime} \mathrm{N}, 60^{\circ} 24^{\prime} \mathrm{W}$ ) in the rio Branco basin, with limited remaining dark pigmentation on the head and body (INPA $1860 ; 46 \mathrm{~mm} \mathrm{SL}$ ), is apparently a member of the complex of species of Cetopsis characterized by the presence of a bilobed patch of dark pigmentation at the base of the caudal fin. Additional material is necessary to determine whether that specimen represents a range extension for C. arcana, another species of that complex, or an undescribed form.

Material examined. 19 specimens (23-90 mm SL). Holotype. Brazil. Goiás: São Domingos, Parque Estadual de Terra Ronca, Boca da Lapa de Bezerra (13³2'43"S, 46²2'35"W), A. Akama, 24 July 1999, MZUSP 58637, 1 (76). Paratypes. 8 specimens (8, 45-90 $\mathrm{mm}$ SL). Brazil. Goiás: São Domingos, sumidouro (sinkhole) of rio da Lapa, Parque Estadual de Terra Ronca, approximately $100 \mathrm{~m}$ from sinkhole, M. E. Bichuette \& R. dos Santos, 19 July 1999, MZUSP 55965, 3 (69-90, 1 specimen, $85 \mathrm{~mm}$, cleared and stained); USNM 372765, 1 (67). Arroio Arara, $500 \mathrm{~m}$ from mouth of rio Maranhão in Rosariana ( $\left(14^{\circ} 01^{\prime} \mathrm{S}, 48^{\circ} 25^{\prime} \mathrm{W}\right), \mathrm{R}$. E. Reis et al., 14 July 1992, MCP 16002, 1 (86). rio Tocantins, Córrego Agua Boa,

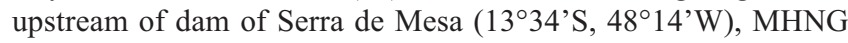

2593.99, 1 (47). Córrego Taquaral, left bank tributary of rio das Almas, of rio Maranhão, upper Tocantins (14³8'S, 499'30"W), G. W. Nunan \& D. F. Moraes, 4 October 1985, MNRJ 12772, 1 (83). Rio Tocantins, at site of future dam of Usina Hidroeléctrica Serra da Mesa (133' 'S, 48 $14^{\circ}$ 'W), D. F. Moraes et al, July 1988; MNRJ 16942, 1 (45). Non-type specimens. 10 specimens (23$54.5 \mathrm{~mm} \mathrm{SL}$ ). Brazil. Mato Grosso: rio Araguaia basin, creek tributary to ribeirão Lajeadinho, below the ferry, MZUSP 41462, 1 (54.5). Município Alto Araguaia, rio Taquari basin, Fazenda Córrego do Mato, córrego do Mato, MZUSP 41492, 6 (23-49; 2 specimens, 35-43 mm, cleared and stained). Pará: rio Itacaiunas, Caldeirão, igarapé do Pojuca ( $\left.5^{\circ} 45^{\prime} \mathrm{S}, 50^{\circ} 30^{\prime} \mathrm{W}\right)$, MZUSP 31432, 1 (50). Rio Tocantins, Tucuruí, INPA 13004, 1 (24). Rio Tocantins, above Tucuruí, INPA 6504, 1 (35).

\section{Cetopsis baudoensis (Dahl, 1960)}

Figs. 12, 14, Tables 9-15

Pseudocetopsis baudoênsis Dahl, 1960b: 452, unnumbered Fig. on page 453 [type locality: (Colombia): Quitasol, Baudó; also reported from Amparraidó, Baudó].-Vari \& Ferraris, 2003: 258 [in check list; distribution].

Pseudocetopsis baudoensis.-Cala, 1981: 4 [in listing of type specimens in ICN-MHN with citations of catalog numbers].

Hemicetopsis amphiloxa [not of Eigenmann, 1912].-MojicaC., 1999: 565 [in part, citation of species from Colombia, río Baudó].

Diagnosis. Cetopsis baudoensis can be distinguished from all of its congeners by the combination of the presence of an eye, the conical teeth on the vomer and dentary, the rounded posterior nares that is distinctly separated from the contralateral nares by a distance greater than the width of the posterior nares, the wide mouth with its width equal to one-half of HL, the absence of a dark humeral spot, the absence of a posteriorly-rounded, variably-developed, bilobed patch of dark pigmentation at the base of the caudal fin, the absence of a band of dark pigmentation along the distal portions of the anal fin, the possession of small dark spots on the lateral and dorsal surfaces of the body, the absence of eye-size or larger spots on the body, the possession of 9 , rarely 10 , pectoral-fin rays, 18 to 20 preanal vertebrae, 14 to 16 precaudal 
vertebrae, 33 to 35 caudal vertebrae, 47 to 49 caudal vertebrae, 20 to 22 branched anal-fin rays, and 23 to 27 total analfin rays.

Description. Body moderately deep, slightly transversely compressed laterally anteriorly, becoming increasingly compressed posteriorly. Body depth at dorsal-fin origin equal to HL and approximately 0.27 of SL. Lateral line on body complete, unbranched, and midlateral; extending from vertical through pectoral-fin base onto hypural plate with slight dorsal bend on hypural plate. Lateral line terminating at, or slightly posterior of, posterior margin of hypural plate. Dorsal profile of body straight and distinctly inclined from nape to dorsalfin origin; nearly straight from dorsal-fin origin to caudal-fin base. Ventral profile of body slightly convex along abdomen, approximately straight, but posterodorsally-slanted along base of anal fin. Caudal-peduncle depth slightly less than caudal-peduncle length.

Head triangular overall in lateral view and broadly rounded anteriorly. Dorsal profile of head convex from tip of snout to vertical through posterior nares and straight from that point to posterior of nape. Ventral profile of head gently convex. Profile of snout in dorsal view obtusely triangular and rounded at tip. Portion of head posterior of nares with lateral profiles diverging slightly posteriorly from dorsal view. Dorsal surface of posterior portion of head without enlarged jaw musculature externally apparent.

Opercular membrane attaching to isthmus as far as point slightly anterior of vertical through pectoral-fin insertion. Opercular opening relatively wide; extending ventral of pectoral-fin insertion by distance approximately equal to distance from tip of snout to posterior margin of orbit and extending dorsal of pectoral-fin insertion by distance approximately equal to snout length.

Eyes situated on lateral surface of head; located entirely dorsal to horizontal extending through pectoral-fin insertion; eye visible in dorsal view, but not in ventral view, of head. Middle of orbit located slightly anterior of one-fourth of HL. Eye diameter approximately two-thirds of snout length. Interorbital width approximately equal to distance from tip of snout to posterior margin of orbit. Anterior narial opening circular, surrounded by short, anteriorly-directed, tubular rim of skin. Opening of anterior nares located at horizontal extending through tip of snout and slightly dorsal to horizontal running through maxillary-barbel origin. Distance between anterior nares approximately equal to distance from anterior to posterior nares, and approximately equal to snout length. Posterior narial opening large; located near dorsal profile of head and dorsal to anterior one-half of orbit; opening rounded, with anterior two-thirds of aperture bordered by flap of skin. Distance between contralateral posterior nares slightly less than distance between contralateral anterior nares.

Mouth inferior; its width one-half of HL. Margin of lower jaw broadly rounded, its posterior extent reaching slightly beyond vertical through middle of eye. Premaxillary tooth patch elongate, continuous across midline; anterior margin convex, posterior margin concave and running in parallel to anterior margin. Premaxillary teeth moderate, conical, and sharply-pointed, with teeth arranged in three rows across entire tooth patch. Teeth of all tooth rows of approximately same size. Vomerine teeth arranged in one anteriorly-convex row without medial gap. Vomerine teeth bluntly conical and distinctly larger than premaxillary teeth. Dentary with two rows of teeth. Primary dentary tooth row consisting of conical teeth of approximately same size as those on vomer. Secondary dentary tooth row shorter, located anterior of primary tooth row, and formed of 5 or 6 teeth extending laterally from each side of the symphysis.

Maxillary barbel slender, its length distinctly greater than distance from tip of snout to posterior margin of orbit and nearly equal to one-half of HL; barbel origin located near vertical through anterior margin of orbit. Mental barbels approximately equal in size and slightly shorter than maxillary barbel. Medial mental-barbel origin located along vertical through posterior margin of orbit. Lateral mental-barbel origin located slightly posterior of vertical through posterior margin of orbit. Tips of adpressed mental barbels falling short of posterior margin of opercle.

Dorsal fin moderately large overall with length of dorsalfin base approximately $0.37-0.42$ of $\mathrm{HL}$ and equal to distance from tip of snout to posterior margin of orbit. Longest dorsalfin ray, excluding filament on first dorsal-fin ray of mature males, equal in length to distance from anterior margin of eye to posterior margin of head. Dorsal-fin spinelet absent. First dorsal-fin ray not spinous; with very slight, distal, filament in females and immature males and moderately long filament in single, available, adult male. Distal margin of dorsal fin nearly straight, with first ray longest. Dorsal-fin origin located at approximately anterior one-third of SL and along vertical through middle of adpressed pectoral fin. Tip of adpressed dorsal fin, excluding distal filament on first ray, reaching to vertical through distal one-fourth of adpressed pelvic fin. Posterior most dorsal-fin ray without posterior, membranous attachment to body.

Caudal fin deeply-forked, symmetrical; with tips of lobes pointed. Length of longest caudal-fin ray approximately two times length of middle fin rays.

Base of anal fin moderate, approximately 0.30 of SL. Analfin origin located distinctly posterior of middle of SL. Anal-fin margin nearly straight in females and immature males, with posterior most unbranched anal-fin ray longest and lengths of subsequent rays gradually decreasing. Anal-fin margin convex in single available mature male. Posterior most analfin ray with posterior, membranous attachment to body for basal one-fifth of its length.

Pelvic fin large, with distal margin straight and first branched ray longest. Middle of adpressed pelvic fin situated at middle of SL, with origin of fin located posterior of vertical through base of dorsal fin. Tip of adpressed pelvic fin falling slightly short of vent. Medial most pelvic-fin ray with membranous attachment to body for basal two-thirds of its length.

Pectoral-fin length about two-thirds of HL. Pectoral-fin 
margin very slightly convex, with first ray longest. First pectoral-fin ray not spinous and with short, distal filament present only in single, available, adult male.

Coloration in alcohol. Dusky pigmentation formed by small, dark chromatophores located on dorsal and dorsolateral portions of head and body. Dusky pigmentation on body in region anterior of vertical through anal-fin origin extending ventrally beyond lateral line to horizontal extending through pectoral-fin insertion. Abdomen, underside of head, and region immediately dorsal of base of anal fin virtually without dark pigmentation. Portion of lateral surface of head ventral of horizontal extending through maxillary barbel together with underside of head without dark pigmentation. Tip of snout with limited dark pigmentation. Dorsal fin with scattered, dark pigmentation across basal portion of fin and along at least basal one-half of first fin ray. Pectoral, pelvic, and anal fins without dark pigmentation. Caudal fin with scattered, dark pigmentation across fin base, and with spots of dark pigmentation extending across basal one-half of upper lobe.

Maxillary barbel darkly pigmented for most of its length, with tip generally pale. Mental barbels either unpigmented or with scattered, dark pigmentation.

Sexual dimorphism. Mature males of Cetopsis baudoensis have the distal filament on the first ray of the dorsal fin longer than in females and immature males and with a slight filament on the first ray of the pectoral fin contrary to the absence of that structure in conspecific females and immature males. The anal-fin margin is convex in mature males contrary to being nearly straight in females and immature males.

Distribution. Cetopsis baudoensis is only known from the río Baudó basin of the Pacific Ocean versant of western Colombia (Fig. 12).

Ecology. The majority of the examined specimens of Cetopsis baudoensis, (NRM 27738, 31747) were collected from a highly turbid, white-water river over clay bottoms with logs in the main channel and clay and leaves in the lower portions of the quebradas that were tributary to the main river channel. Specimens were collected at depths of $2 \mathrm{~m}$ or less and at an elevation of less than 50 m (S. O. Kullander, NRM; pers. commun., 2001).

Remarks. In his original description of Pseudocetopsis baudoênsis, Dahl (1960b: 452) neglected to provide the cata$\log$ numbers for the type series of the species. Cala (1981:4) reported that the holotype of $P$. baudoensis, ICN-MHN 118, is $106.4 \mathrm{~mm} \mathrm{SL}$ and that the four extant paratypes of the species are catalogued as ICN-MHN 100, with the largest paratype $241 \mathrm{~mm}$ SL.

Mojica-C. (1999: 565) reported Hemicetopsis amphiloxa (the Cetopsis amphiloxa of this paper) from the río Baudó. That record presumably refers to Cetopsis baudoensis that is the only member of the Cetopsinae known from that river basin. Further support for this supposition comes from the fact that Cetopsis baudoensis was not cited as a recognized species by Mojica-C. (1999) in his compilation of the species of the Cetopsinae of Colombia.

Material examined. 15 specimens (54-187 mm SL). Colombia. Choco: río Baudó drainage, Boca de Pepé, various tributaries and river close to village $\left(5^{\circ} 04^{\prime} \mathrm{N}, 77^{\circ} 03^{\prime} \mathrm{W}\right)$, NRM 27738,12 (54-98); NRM 31747, 1 specimen cleared and stained, originally part of NRM 27738). Pizarrro ( $\left.4^{\circ} 58^{\prime} \mathrm{N}, 77^{\circ} 22^{\prime} \mathrm{W}\right)$, FMNH 70339, 2 (163187 , smaller specimen adult male).

\section{Cetopsis caiapo, new species}

Figs. 12, 15, Tables 9-15

Diagnosis. Cetopsis caiapo can be distinguished from all of its congeners by the combination of the presence of an eye, the large conical teeth on the vomer and dentary, the rounded posterior nares that is distinctly separated from the contralateral nares by a distance greater than the width of the posterior nares, the dark humeral spot, the absence of a posteriorly-rounded, variably-developed, bilobed patch of dark pigmentation at the base of the caudal fin, the absence of a band of dark pigmentation along the distal portions of the anal fin, and the possession of 44 total vertebrae, 29 caudal vertebrae, 22 total anal-fin rays, and 18 branched anal-fin rays.

Description. Body relatively rounded transversely, somewhat compressed anteriorly, becoming increasingly compressed posteriorly. Body depth at dorsal-fin origin approximately 0.29 of SL, and approximately equal to HL. Lateral line on body complete, unbranched, and midlateral; extending from vertical through pectoral-fin base onto, and slightly upturned on, hypural plate and terminating prior to posterior margin of hypural plate. Dorsal profile of body nearly straight from nape to dorsal-fin origin, nearly straight from dorsal-fin origin to caudal-fin base. Ventral profile of body convex along abdomen, approximately straight, but posterodorsally-slanted along base of anal fin. Caudal-peduncle depth approximately twice caudal-peduncle length.

Head triangular in lateral view and tapering to blunt point anteriorly. Dorsal profile of head slightly convex from tip of snout to vertical though posterior margin of eye, nearly straight from that point to posterior margin of head. Ventral profile of head slightly convex. Profile of snout in dorsal view acutely-pointed, with rounded tip. Width of head gradually increasing posterior of orbit. Dorsal surface of postorbital part of head dominated by enlarged, externally apparent, jaw musculature in form of bilateral, convex swellings extending from orbit to nape. Eye obscured by thick, overlying, integumentary tissues, but, nonetheless, apparent with close inspection.

Opercular membrane attaching to isthmus as far posteriorly as vertical through pectoral-fin insertion. Opercular opening relatively large; extending ventral of pectoral-fin insertion by distance equal to snout length. 


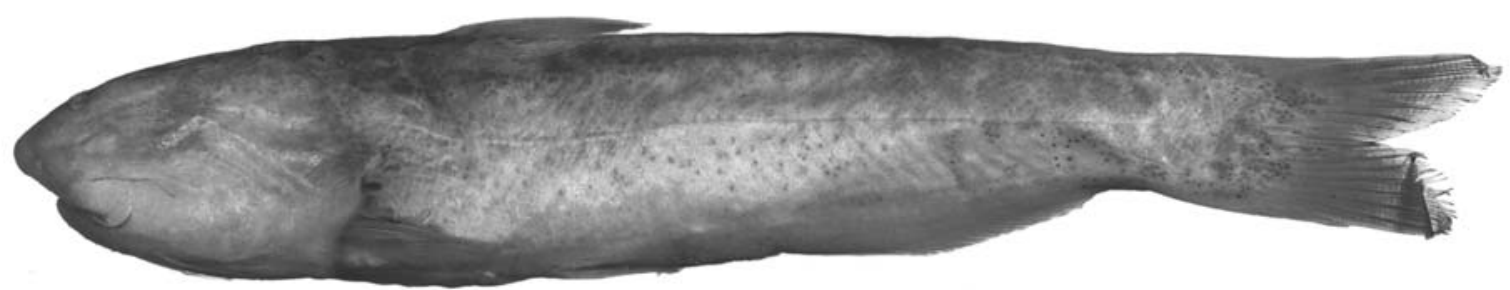

Fig. 15. Cetopsis caiapo, new species, holotype, MNRJ 13236, 69 mm SL; Brazil, Goiás, Município de Minaçu/Cavalcante, rio Tocantins, at location of the future dam of the Usina Hidroeléletrica Serra da Mesa (135ํ소 $\left.48^{\circ} 19^{\prime} \mathrm{W}\right)$.

Eye situated on lateral surface of head; located entirely dorsal to horizontal extending through pectoral-fin insertion; eye visible in dorsal view, but not in ventral view, of head. Middle of orbit at approximately anterior one-third of HL. Eye diameter approximately one-half of snout length. Interorbital width approximately equal to distance from tip of snout to posterior margin of orbit. Anterior narial opening circular, surrounded by short, anteriorly-directed, tubular rim of skin. Opening of anterior nares located ventral of horizontal extending through tip of snout and at horizontal extending through maxillary-barbel origin. Distance between anterior nares approximately equal to snout length. Posterior narial opening positioned on dorsal surface of head, located along vertical through anterior margin of orbit; opening slightly ovoid, with long axis of aperture aligned parallel to body axis. Anterior two-thirds of posterior narial opening bordered by flap of skin, with flap highest anteriorly. Distance between contralateral posterior nares slightly less than distance between contralateral anterior nares.

Mouth inferior; its width approximately one-half of HL. Margin of lower jaw broadly rounded, its posterior extent reaching vertical through posterior margin of orbit. Premaxillary tooth patch elongate and continuous across midline with anterior margin convex and posterior margin nearly straight. Premaxillary teeth small, conical, and sharply-pointed, with teeth arranged in five or six irregularly-arranged rows. Vomerine teeth arranged in one anteriorly-convex row with length of vomerine tooth row approximately equal to that of premaxillary tooth patch. Vomerine teeth large and bluntly conical. Dentary with single row of large, conical teeth approximately equal in size and number to teeth on vomer.

Maxillary barbel slender, its length approximately equal to distance from tip of snout to posterior margin of orbit. Maxillary-barbel origin located ventral to middle of orbit. Mental barbels approximately equal in size and length to maxillary barbel and to each other. Medial mental-barbel origin located along vertical through posterior margin of orbit. Lateral mental-barbel origin located slightly posterior of vertical through posterior margin of orbit. Tips of adpressed mental barbels falling short of posterior margin of opercle.

Dorsal fin relatively small overall, with length of dorsalfin base approximately $0.43-0.48$ of HL. Length of longest dorsal-fin ray equal to length of post-orbital portion of head. Dorsal-fin spinelet absent. First dorsal-fin ray not spinous and lacking distal filament. Distal margin of dorsal fin straight, with first ray longest. Dorsal-fin origin located at approximately anterior one-third of SL and along vertical extending through middle of adpressed pectoral fin. Tip of adpressed dorsal fin reaching to vertical through middle of pelvic-fin base. Posterior most dorsal-fin ray without posterior, membranous attachment to body.

Caudal fin shallowly-forked, symmetrical; tips of lobes slightly rounded. Length of longest caudal-fin ray approximately 1.5 times length of middle fin rays.

Base of anal fin comparatively short. Anal-fin origin located well posterior of middle of SL, and approximately at middle of TL. Anal-fin margin nearly straight. Posterior most unbranched anal-fin ray longest, with subsequent rays gradually becoming shorter. Posterior most anal-fin ray without posterior, membranous attachment to body.

Pelvic fin short, rounded, with first branched ray longest. Pelvic-fin insertion located anterior to middle of SL and posterior to vertical through posterior terminus of base of dorsal fin. Tip of adpressed pelvic fin extending beyond middle of SL, but falling short of vent. Medial most pelvic-fin ray with membranous attachment to body for basal one-half of its length.

Pectoral-fin length approximately one-half of HL. Pectoral-fin margin convex with first ray longest. First pectoral-fin ray not spinous and without distal filament.

Coloration in alcohol. Scattered, dark pigmentation present on most surfaces of head and body, with dark pigmentation slightly more concentrated dorsally. Dark pigmentation absent on ventral surface of head and abdomen. Dark humeral mark, several times larger than eye diameter, situated immediately posterior of membrane on opercle and dorsal to pectoral-fin base (note: holotype, the only known specimen, bleached on left side of head and body and therefore dark blotch on opercle not apparent in Fig. 15).

Caudal-fin base with scattered, dark pigmentation. Other fins lack dark pigmentation.

Barbels pale.

Sexual dimorphism. The single known specimen of Cetopsis caiapo, of unknown sex, does not demonstrate the sexuallydimorphic modifications of the form of the dorsal, anal, and pectoral fins that are present in mature males of many species of the Cetopsinae. 
Distribution. Cetopsis caiapo is only known from one locality in the rio Tocantins basin, Brazil (Fig. 12).

Etymology. The species name, caiapo, is in reference to the Caiapo Amerindian tribe that historically inhabited the area of the rio Tocantins drainage system from which the holotype of the species originated.

Material examined. 1 specimen (1, $69 \mathrm{~mm}$ SL). Holotype. Brazil. Goiás: Município de Minaçu/Cavalcante, rio Tocantins, at location of the future dam of the Usina Hidroeléletrica Serra da Mesa (13 ${ }^{\circ} 50^{\prime} \mathrm{S}$, 48¹9'W); D. F. Moraes et al., 24 to 31 July1988, MNRJ 13236, 1 (69.0).

\section{Cetopsis candiru Spix \& Agassiz, 1829}

Figs. 12, 16, 17, Tables 9-15

Silurus candira.-Cuvier, 1829: 292 [nomen nudum].

Cetopsis candiru Spix \& Agassiz, 1829: 13, pl. 10, fig. 1 [type locality: Brasiliae aequatorialis fluvis (=rivers of Equatorial Brazil)].-Eigenmann \& Eigenmann, 1888: 157 [Brazil: Tabatinga, Jutahy (=Jutaí), Tonantins, Iça]; 1890: 319 [redescription, Amazon basin]; 1891: 36 [in listing of Cetopsis species].-Boulenger, 1898a: 422 [Brazil, rio Jurua].Pearson, 1924: 16 [Bolivia, Rurrenbaque]; 1937b: 111 [Bolivia, río Beni-Mamoré basin].-Magalhães, 1931: 106 [Brazil, feeding habits, distribution].-Fowler, 1940b: 97 [Bolivia].-Kottelat, 1984: 149 [syntype depository]; 1988: 84 [authorship of species name; syntype depositories].Weber, 1998: 9 [syntype depository].

Cetopsis spixii.-Swainson, 1839: 308 [unnecessary replacement for Cetopsis candiru Spix \& Agassiz, 1829].

Cetopsis candira.-Cuvier \& Valenciennes, 1840: 386 [redescription].-Bleeker, 1858: 258 [Brazil].-Cope, 1878: 678 [Peruvian Amazon].

Hemicetopsis candira.-Bleeker, 1862a: 403 [assignment to Hemicetopsis and designated as type species of genus, brief description]; 1862b: 16 [brief description]; 1863: 111 [brief description].

Hemicetopsis candiru.-Eigenmann \& Bean, 1907: 664 [Amazon River between Para $(=$ Belém) and Manaos (=Manaus)].-Eigenmann, 1910: 398 [distribution].Miranda-Ribeiro, 1912: 381 [Brazil; redescription; common name]; 1914: 11 [Brazil, Manáos (=Manaus)]; 1920: 15 [Brazil, rio Madeira].-Fowler, 1915: 238 [Peruvian Amazon]; 1940a: 232 [Peru, Ucayali River]; 1941: 472, fig. 29 [Peru]; 1945: 68, fig. 29 [Peru]; 1954: 3 [literature compilation].Eigenmann \& Allen, 1942: 148 [Peru: río Ucayali near Cashiboya, río Puinagua at Bretaña; diet; common name].Gosline, 1945: 54 [distribution].-Ovchynnyk, 1967: 35 [Ecuador, río Panayuca]; 1968: 255 [Ecuador, río Panayuca].Terrazas-Urquidi, 1970: 21 [Bolivia, río Beni; based on literature].-Baskin et al., 1980: 183 [feeding on offal and blood].-Ortega \& Vari, 1986: 15 [Peru: Amazon basin; common name].-Stewart et al., 1987: 33 [Ecuador, río Napo].Burgess, 1989: 292 [in list of species in Hemicetopsis].-
Lauzanne et al., 1991: 69 [Bolivia, Trinidad].-Barriga, 1991: 56 [eastern Ecuador]; 1994a: 31 [Ecuador, Parque Nacional Yasuni].-Ferraris, 1996: 164 [form of adductor mandibulae].-Chang, 1998: 26 [Peru, río Madre de Dios basin, Tambopata-Candamo Reserved Zone].-Silvano et al., 2001:34, unnumbered fig. on page 35 [Brazil, rio Jurua].Vari \& Ferraris, 2003: 258 [in check list; synonymy, distribution, common names].

Diagnosis. Cetopsis candiru can be distinguished from all of its congeners by the combination of its relatively shallow body at the origin of the dorsal fin ( 0.20 of SL or less versus 0.22 of SL or more, respectively) and the form of the teeth on the vomer and dentary (incisiform versus conical, respectively).

Description. Body relatively elongate, rounded in cross-section anteriorly, becoming increasingly laterally compressed posteriorly. Body depth at dorsal-fin origin approximately 0.17 0.20 of SL and approximately equal to HL. Lateral line on body complete, unbranched, and midlateral; extending from vertical through pectoral-fin base onto, and straight or slightly upturned on, hypural plate and terminating slightly anterior to posterior margin of hypural plate. Dorsal profile of body slightly convex from nape to dorsal-fin origin and straight from dorsal-fin origin to caudal-fin base. Ventral profile of body variably convex along abdomen, approximately straight, but posteriorly slanted, along base of anal fin. Caudal-peduncle depth approximately equal to caudal-peduncle length.

Head triangular overall in lateral view and broadly rounded anteriorly. Dorsal profile of head convex from tip of snout to vertical through eye, straight from that point to nape. Profile of head from dorsal view broadly rounded anteriorly, with margins of head posterior of orbit running approximately in parallel. Jaw musculature not noticeably enlarged on dorsal surface of postorbital portion of head.

Opercular membrane attaching to isthmus posteriorly as far as vertical through pectoral-fin insertion. Opercular opening relatively small; extending dorsally only to pectoral-fin insertion, and extending ventral of pectoral-fin insertion by distance equal to snout length.

Eye situated on dorsolateral surface of head; located entirely dorsal of horizontal extending through pectoral-fin insertion. Middle of orbit at approximately anterior one-fifth of HL. Eye diameter approximately equal to width of anterior nares. Interorbital width approximately equal to two-fifths of HL. Anterior narial opening circular, surrounded by short, anteriorly-directed, tubular rim of skin. Opening of anterior nares located slightly ventral of both horizontal extending through tip of snout and of horizontal running through maxillary-barbel origin. Distance between anterior nares approximately equal to distance between anterior and posterior nares. Posterior narial opening on dorsal surface of head, situated at horizontal extending through anterior margin of orbit; opening ovoid and with long axis of aperture oriented perpendicular to body axis. Entire posterior narial opening bordered by tube of skin, distal margin of tube higher anteriorly. Distance 


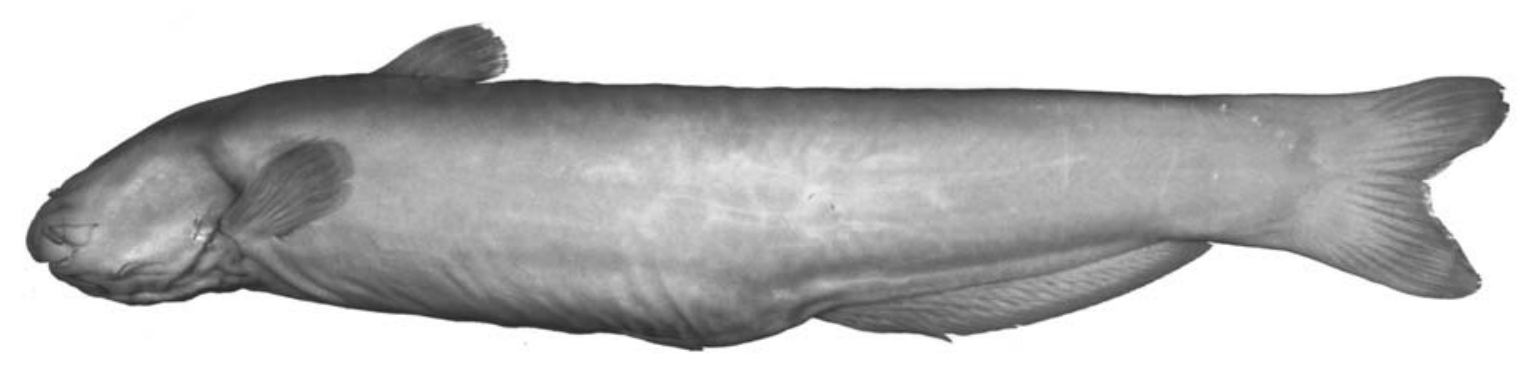

Fig. 16. Cetopsis candiru, MCZ 56018, female, $131 \mathrm{~mm} \mathrm{SL}$; Brazil, Amazonas, rio Solimões approximately $0.5 \mathrm{~km}$ from mouth of paraná de Januaca, on south bank of river $\left(3^{\circ} 25^{\prime} \mathrm{S}, 61^{\circ} 21^{\prime} \mathrm{W}\right)$.

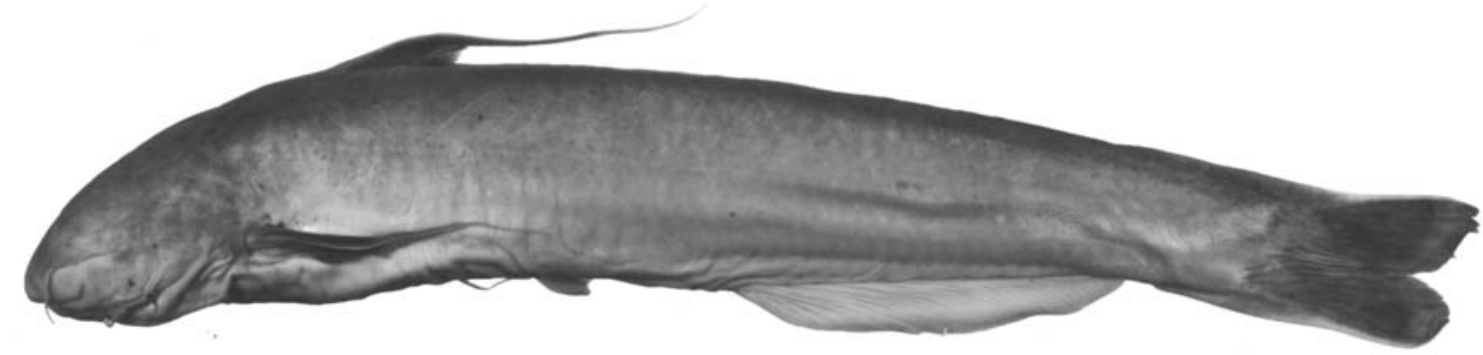

Fig. 17. Cetopsis candiru, mature male, FMNH 112635, $194 \mathrm{~mm}$ SL; Peru, Loreto, río Pastaza basin, caño tributary to laguna Rimachi, near río Rimachi, at Rimachi (4²6.91’S, 76³9.48’W).

between posterior nares slightly less than distance between contralateral anterior nares.

Mouth inferior; width approximately one-half of HL. Margin of lower jaw distinctly truncate, its posterior extent reaching to vertical through middle of orbit. Premaxillary teeth incisiform and arranged in single elongate row continuous across midline; tooth row in form of gently curved arch. Vomerine teeth incisiform and arranged in single gently curved, continuous row. Dentary with single row of incisiform teeth much larger than those on both premaxilla and vomer.

Maxillary barbel slender, its length approximately equal to one-third of HL; barbel origin located ventral to anterior margin of orbit. Mental barbels approximately equal in size and length to maxillary barbel. Origin of medial-mental barbel situated along vertical through rictus of jaw. Lateral mental-barbel origin located slightly posterior of vertical through rictus of jaw. Tips of adpressed mental barbels falling far short of opercular opening.

Dorsal fin small overall, with length of dorsal-fin base approximately one-fourth of HL. Longest dorsal-fin ray, excluding distal filament on first ray present in mature males, approximately equal in length to one-third of HL. Dorsal-fin spinelet absent. First dorsal-fin ray not spinous; with at least short, distal filament in females and immature males and with elongate, distal, filament in mature males. Distal margin of dorsal fin slightly convex, with first branched ray longest.

Tip of adpressed dorsal fin falling short of pelvic-fin insertion by distance equal to length of pectoral fin. Posterior most dorsal-fin ray without posterior, membranous attachment to body.

Caudal fin shallowly-forked, symmetrical; lobes broadly rounded. Length of longest caudal-fin ray approximately 1.51.6 times length of middle fin rays.

Base of anal fin approximately $0.29-0.31$ of SL. Anal-fin origin located distinctly posterior of middle of SL and slightly posterior of middle of TL. Anal-fin margin gently convex for entire length in all individuals. Posterior most unbranched anal-fin ray longest, with subsequent rays becoming gradually shorter in females and immature males, but with fin margin distinctly convex in mature males. Posterior most anal-fin ray without posterior, membranous attachment to body.

Pelvic fin very short, paddle-shaped, with margin symmetrically rounded and middle fin-rays longest. Pelvic-fin insertion situated slightly anterior to middle of SL. Tip of adpressed pelvic fin reaching posteriorly to middle of SL. Medial most pelvic-fin ray without membranous attachment to body.

Pectoral-fin length approximately one-half of HL. Pectoral-fin margin rounded with second branched fin ray longest. First pectoral-fin ray not spinous and without distal filament in females and immature males, but with moderately-developed, distal filament in mature males.

Coloration in alcohol. Body and head with indistinct duskiness dorsally and pale ventrally.

Dorsal and pectoral fins with subterminal, dark, band curving across fin approximately three-fourths of distance from base, with remainder of both fins dusky. Anal, caudal, and pelvic fins unpigmented.

Barbels unpigmented.

Sexual dimorphism. The first ray of the dorsal fin of mature 
males of Cetopsis candiru is prolonged to varying degrees beyond the condition present in both females and immature males. Mature males also have a moderately-developed, distal filament on the first pectoral-fin ray, whereas such extensions of that fin ray are absent in both females and immature males. The convexity of the anal-fin margin in mature males is distinctly more pronounced than is the form of the fin margin that characterizes both females and immature males of the species. The smallest obviously sexually mature male of $C$. candiru examined in this study (MZUSP 24602) is $145 \mathrm{~mm} \mathrm{SL}$. A slightly smaller $137 \mathrm{~mm}$ SL specimen of $C$. candiru (MZUSP 55634) demonstrated the beginnings of the male sexuallydimorphic features characteristic of the species.

Distribution. Examined specimens of Cetopsis candiru originated across a broad reach of the Amazon basin in Bolivia, Brazil, and Peru (Fig. 12) and the species has been reported from eastern Ecuador by Ovchynnk (1967: 35), Stewart et al. (1987: 33), and Barriga (1991: 56; 1994a: 31).

Common Name. Bolivia: "Candiru," "Canero" (TerrazasUrquidi, 1970: 21); Peru: “Canero" (Ortega \& Vari, 1986: 15).

Remarks. Kottelat (1984: 149; 1988: 84) and Weber (1998: 9) reported that four syntypes for Cetopsis candiru are extant. We have examined one of the syntypes (MHNG 210.5) that in combination with the original description, make it clear that the material identified herein as Cetopsis candiru is indeed that species. We herein designate that syntype as the lectotype of Cetopsis candiru.

Material examined. 220 specimens (18-263 mm SL). Bolivia. Beni: río Beni at Rurrenbaque, $1500 \mathrm{ft}(=457 \mathrm{~m})$ elevation $\left(14^{\circ} 28^{\prime} \mathrm{S}\right.$, 67³4'W), CAS 77024, 1 (232). Río Mamoré, Boca río Ibare (14³7’S, 645' 'W), MNHN 1988-1997, 5 (105-141). Brazil. "Equatorial Rivers of Brazil," MHNG 210.5, 1 (135; lectotype of Cetopsis candiru; designated herein). Rio Amazonas, between Pará and Manaus, USNM 52546, 1 (158, mature male). Rio Araguaia, LIRP 581, 2 (116-132). Acre: Reserva Extrativista do Alto rio Juruá, MZUSP 53015, 1 (150). Amazonas: rio Solimões approximately $0.5 \mathrm{~km}$ from mouth of Paraná de Januacá, on south bank (3²5'S, 6121 'W), MCZ 56018, 1 (131). Lago Jacaretinga, near Manaus, MCZ 78099, 2 (18-25). Rio Madeira, Borba (4²4'S, 59³5'W), MNRJ 4819, 2 (102-197); MZUSP 28350, 1 (74). Município de Borba, Borba, MZUSP 28349, 5. Rio Juruá, Eirunepé (640’S, 6952'W), MNRJ 5878, 20 (80-180). Rio Solimões, $6.5 \mathrm{~km}$ below Solimões (2॰55'25'S, 6751'23), MZUSP 56822,1 (92). Rio Solimões, Ilha dos Corós, above Codajás ( $3^{\circ} 50^{\prime} \mathrm{S}$, $\left.62^{\circ} 05^{\prime} \mathrm{W}\right)$, MZUSP 23249, 12 (93-205). Rio Jauaperi, from mouth to $100 \mathrm{~km}$ upstream, MZUSP 23287, 1 (140). Rio Solimões, near Tefé (approximately 322'S, 6442'W), MZUSP 23319, 3 (87-185, $178 \mathrm{~mm}$ specimen mature male). Igarapé em Jacaré, Fonte Boa (2³2'S, $\left.66^{\circ} 01^{\prime} W\right)$, MZUSP 23355, 4 (95-125). Mouth of rio Içá, Santo Antonio do Içá ( $3^{\circ} 05^{\prime}$ S, $\left.67^{\circ} 57^{\prime} \mathrm{W}\right)$, MZUSP 23521, 11 (5, 80-173, largest specimen mature male). Rio Amazonas, Ilha Beiju-Açu ( $2^{\circ} 25^{\prime} \mathrm{S}$, $\left.57^{\circ} 31^{\prime} \mathrm{W}\right)$, MZUSP 23753, 2 (92-205). Mouth of rio Pauini ( $7^{\circ} 12^{\prime} \mathrm{S}$, 69³6'W), MZUSP 24595, 1 (190). Pauini (740'S, 6658'W), MZUSP 24602, 1 (145, mature male). Canutama, MZUSP 24615, 1 (187). Rio Purus, Mapixi (540'S, 635' 'W), MZUSP 24683, 6 (108179, 138 mm specimen mature male); ROM 37966, 5 (121-146). Rio

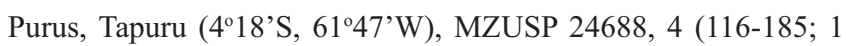
specimen, $185 \mathrm{~mm}$, cleared and stained). Rio Purus, Caitaú, MZUSP 30693, 1 (93). Rio Purus, at mouth, MZUSP 5969, 1 (134). Rio Madeira, Humaitá (7³1'S, 6302'W), MZUSP 35421, 8 (197-229); MZUSP 28732, 8 (147-226). Carauari (452'S, 66 $\left.{ }^{\circ} 54^{\prime} \mathrm{W}\right)$, MZUSP 30696, 1 (96). Rio Negro, Anavilhanas, along bank of lagoon, MZUSP 31331, 1 (86). Rio Solimões, Marchantaria, above Manaus (approximately 308'S, 6000'W), MZUSP 38827, 2 (168-190, smaller specimen mature male). Rio Amazonas, Ilha do Beijú-Açu (2 $25^{\prime} \mathrm{S}$, 57³1'W), MZUSP 52898, 1 (217). Rio Amazonas, Nova Olinda ( $3^{\circ} 45^{\prime}$ 'S, $\left.59^{\circ} 03^{\prime} \mathrm{W}\right)$, MZUSP 52899, 1 (215). Rio Solimões, mouth of lago Preto (approximately $4^{\circ} 00^{\prime} \mathrm{S}, 6^{\circ} 05^{\prime} \mathrm{W}$ ), MZUSP 5874, 1 (214). Rio Solimões, between lago Jacaré and rio Purus, MZUSP 5935, 7 (58-225, $182 \mathrm{~mm}$ specimen mature male). Rio Solimões, above Ilha Iauara (approximately $3^{\circ} 38^{\prime} \mathrm{S}, 6^{\circ} 22^{\prime} \mathrm{W}$ ), MZUSP 6272, 3 (54- approximately 120 ; largest specimen cleared and stained). Mouth of lago Panaquequara, MZUSP 6913, 1 (121). Rio Solimões, paraná do Moreru (350'S, 6947’W), MZUSP 9599, 5 (63-83). Rio Negro, 9.3 $\mathrm{km}$ below lago da Cotia $\left(1^{\circ} 45^{\prime} 15^{\prime \prime S} 62^{\circ} 25^{\prime} 08^{\prime \prime W}\right)$, MZUSP 55643 , 15 (95-158, $137 \mathrm{~mm}$ specimen demonstrates indications of male sexually-dimorphic features). Goiás: Município de Minaçu/Cavalcante, rio Tocantins, at site of future dam of Usina Hidroeléctrica Serra da Mesa (1350'S, 48¹9'W), MNRJ 13250, 2 (94-103). Serra da Mesa, MZUSP 54086, 2 (104-108). Pará: Boa Fé, Furo de Tajapuru (4³6'S, 56²'W), MZUSP 24228, 1 (154). Ilha Redonda, near Gurupá (125'S, 513' 'W), MZUSP 24229, 2 (110-143). Rio Amazonas, Taperinha (2'32'S, 54ำ $\left.17^{\prime} \mathrm{W}\right)$, MZUSP 24232, 1 (116). Rio Trombetas, at mouth of lago Paui, Oriximiná $\left(1^{\circ} 45^{\prime} \mathrm{S}, 55^{\circ} 22^{\prime} \mathrm{W}\right)$, MZUSP 5684, 4 (42-133). Rio Amazonas, Itamarati, exit from Furo de Tajapuru ( $\left.1^{\circ} 08^{\prime} \mathrm{S}, 51^{\circ} 11^{\prime} \mathrm{W}\right)$, MZUSP 9140, 2 (117-130). Rio

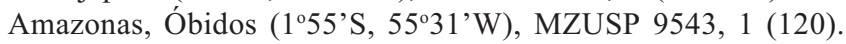
Rondônia: rio Madeira, Foz do Jamarí ( $8^{\circ} 45^{\prime}$ S, 632ㄱ'W), MZUSP 28371, 1 (173). Rio Madeira, Porto Velho ( $8^{\circ} 45^{\prime}$ S, $\left.63^{\circ} 54^{\prime} \mathrm{W}\right)$, MZUSP 36764, 2 (174-179). Tocantins: rio Tocantins at Porto Nacional (1042' $\left.\mathrm{N}, 48^{\circ} 25^{\prime} \mathrm{W}\right)$, CAS 6610, 1 (210); CAS 77023, 1 (203). Indefinite locality: MZUSP 48102, 15 (94-186; 3 specimens, $82-130 \mathrm{~mm}$, cleared and stained). Peru. Río Cucaya, at its mouth, CAS 16024, 1 (116; co-ordinates of location unknown). Amazonas: río Santiago, $1.5 \mathrm{~km}$ upstream of La Poza (latter locality at: $4^{\circ} 01^{\prime} \mathrm{S}$, 77²5'W), LACM 39864-2, 4 (244-263). Loreto: rio Amazonas, between Iquitos and mouth of rio Marañon, along E bank, AMNH 78109 SW, 2 ( 123-175; specimens cleared and stained). Rio Amazonas, at Ramón Castilla (4¹4'S, 6957'W), CAS 65902, 12 (67-118). Río Yaguas at Puerto Armondito, from inside a Brachyplatystoma, CAS 65904, 1 (142). Pebas (approximately $3^{\circ} 20^{\prime}$ 'S, $\left.71^{\circ} 49^{\prime} \mathrm{W}\right)$, ANSP 21502, 3 (183-220; locality originally reported as being in Ecuador). Río Amazonas, near Pebas (approximately 320'S, $71^{\circ} 49^{\prime}$ W), CAS SU 17205, 1 (192). Río Ambiyacu, near Pebas (approximately 320'S, $\left.71^{\circ} 49^{\prime} \mathrm{W}\right)$, CAS SU 36190, 1 (238). Contamana, río Ucayali basin $\left(7^{\circ} 30^{\prime} \mathrm{S}, 7^{\circ} 01^{\prime} \mathrm{W}\right)$, ANSP 88079, 2 (140-165). Río Pastaza basin, caño tributary to laguna Rimachi, near río Rimachi, at Rimachi (4²6.91'S, 76³9.48'W), FMNH 112635, 1 (194); FMNH 112634, 1 (136). Madre de Dios: río Madre de Dios, Albergue CuzcoAmazonico, CAS 59458, 1 (144). Río Tambopata, Tambopata, Departamento Tres Chimbadas (1247'29"S, 69¹9'13"W), MUSM 9851, 3 (206-210). Ucayali: río Ucayali near lago Cashiboya (7³3'S, 7453'W), CAS 16023, 8 (97-139). Río Ucayali, Pucallpa (8²3'S, 74³2'W), MZUSP 26419, 1 (123); MUSM 13257, 1 (104). Río Ucayali, Masisea ( $8^{\circ} 36^{\prime}$ S, $\left.7^{\circ} 19^{\prime} W\right)$, MZUSP 35934, 1 (128). Río Ucayali, Pucallpa (8²3'S, 74³2'W), MZUSP 35935, 1 (117). Río Ucayali, Nueva Ytalia, near Cashiboya (7033'S, 745' 'W), USNM 167854, 6 (130-152; 2 specimens cleared and stained). 


\section{Cetopsis coecutiens (Lichtenstein, 1819)} Figs. 18,19, Tables 9-15

Silurus coecutiens Lichtenstein, 1819: 61 [type locality: Brazil]; 1823: 112 [Brazil].-Cuvier, 1829: 292 [reference].

Cetopsis coecutiens.-Spix \& Agassiz, 1829: 12, pl. 10, fig. 2 [rivers of equatorial Brazil].-Swainson, 1839: 308 [based on Spix \& Agassiz, 1829].-Bleeker, 1858: 258 [Brazil]; 1862a: 403 [brief description]; 1862 b: 16 [brief description, designation as type species of Cetopsis]; 1863: 111 [brief description].-Cope, 1872: 292 [between mouth of the rio Negro and the Peruvian Amazon or Ucayale River (=río Ucayali)].-Eigenmann \& Eigenmann, 1888: 157 [Brazil: Gurupa]; 1890: 320 [redescription; lower Amazon basin]; 1891: 36 [in listing of Cetopsis species].-Goeldi, 1898: 479 [Amazon].-Boulenger, 1897: 297 [Brazil, Island of Marajo].-Regan, 1905: 190 [rio Negro].-Eigenmann, 1909: 322 [distribution]; 1910: 398 [distribution, not Irisanga citation].-Fowler, 1915: 228 [Ambiyacu River, and Amazon between mouth of rio Negro and Peru]; 1941: 472, fig. 30 [Peru].-Schultz, 1944: 252 [literature records for Venezuela].-Fowler, 1945: 20, fig. 30 [Peru].-Gosline, 1945: 54 [distribution, not Irisinga citation].-Van der Stigchel, 1947: 112 [Brazil, Gurupá; redescription].-Fowler, 1954: 3 [literature compilation].-Dahl, 1960a: 306 [Colombia, río Guayabero].-Ovchynnyk, 1967: 35 [Ecuador, río Panayuca]; 1968: 255 [Ecuador, río Panayuca].-MagoLeccia, 1967: 255 [llanos of Venezuela]; 1970: 82 [Venezuela, common name].-Cala, 1977: 11 [Colombian Orinoco; common name].-Ortega \& Vari, 1986: 15 [Peruvian Amazon; common name].-Burgess, 1989: 292 [in listing of species].-Barriga, 1991: 56 [eastern Ecuador]; 1994a: 31 [Ecuador, Parque Nacional Yasuni].-Lasso \& Castroviejo, 1992: 74 [Venezuela, río Guaritico; relative abundance].Lasso et al., 1995: 18 [Venezuela, río Guaritico; prey items].Ferraris, 1996: 164 [form of adductor mandibulae muscle].Taphorn et al., 1997: 85 [Venezuela].-Chang, 1998: 26 [Peru, río Madre de Dios basin, Tambopata-Candamo Reserved Zone].-Mojica-C., 1999: 565 [Colombia, río Guaviare, río Meta].-Wallace, 2002: 312, fig. 125 [upper rio Negro; common name].-Evers \& Seidel, 2002: 741 [listing].-Vari \& Ferraris, $2003: 257$ [in check list; synonymy, distribution, and common names].-[not Ringuelet \& Arámburu, 1961: 46; Ringuelet et al., 1967: 348].

Cetopsis caecutiens.-Cuvier \& Valenciennes, 1840: 384 [redescription].-Günther, 1864: 199 [Brazil, rio Cupai].Pellegrin, 1899: 158 [Venezuela, río Apure].-MirandaRibeiro, 1912: 380 [Brazil: Amazon to Cupay, rio Branco; redescription].-Starks, 1913: 34 [Brazil: Pará and rio Madeira].-Miranda-Ribeiro, 1920: 15 [Brazil, rio Madeira, mouth of rio Aripuanã].-Delsman, 1941: 80 [Brazil, rio Trombetas and rio Óbidos].-[not Pozzi, 1945: 262; López et al., 2003:37].

Cetopsis sp.-Goulding, 1981:29, fig. 3.4 [Brazil, rio Madeira, Teotônio rapids, feeding habits].-Castro \& Arboleda, 1988:
12 [Colombia, río Caqueta].-Ferreira et al., 1988: 346 [Brazil, Roraima, rio Mucajai].-Goulding et al., 1988: 123 [Brazil, rio Negro].-Lauzanne et al., 1991: 69 [Bolivia, Trinidad].-Machado-Allison \& Moreno, 1993: 86 [Venezuela, río Orituco].

Cetopsis cf. caecutiens.-Mendes dos Santos et al., 1984: 78

[Brazil, lower rio Tocantins; common names].

Diagnosis. Cetopsis coecutiens can be distinguished from all of its congeners by the combination of the presence of an eye, the conical teeth on the vomer and dentary, a body depth greater than 0.22 of SL, the elongated filaments on the distal portions of the first rays of the dorsal and pectoral fins in all specimens, and the presence of transversely-aligned, slit-like posterior nares.

Description. Body relatively stout, slightly-compressed anteriorly, becoming increasingly compressed posteriorly. Body depth at dorsal-fin origin approximately $0.23-0.27$ of SL, and approximately equal to HL. Lateral line on body complete, unbranched, and midlateral; extending from vertical through pectoral-fin base onto hypural plate and terminating at, or slightly anterior to, posterior margin of hypural plate. Dorsal profile of body straight to slightly convex from nape to dorsal-fin origin, very slightly convex from dorsal-fin origin to caudal-fin base. Ventral profile of body convex along abdomen, approximately straight, but posterodorsally-slanted, along base of anal fin. Caudal-peduncle depth approximately equal to caudal-peduncle length.

Head triangular overall in lateral view and tapering to blunt point anteriorly. Dorsal profile of head slightly concave from tip of snout to nape. Ventral profile of head concave from margin of lower lip to slightly anterior of insertion of barbels and straight from that point to rear of isthmus. Snout obtusely pointed in dorsal view, with margins of head posterior to orbit slightly convex from dorsal view. Dorsal surface of postorbital part of head smooth, with minimal indication of underlying enlarged jaw musculature.

Opercular membrane attaching to isthmus posteriorly as far as vertical through pectoral-fin insertion. Opercular opening moderate; extending dorsal and ventral of pectoral-fin insertion by distance approximately equal to snout length.

Eye situated on lateral surface of head; located entirely dorsal to horizontal extending through pectoral-fin insertion; eye visible in dorsal view, but not in ventral view, of head. Middle of orbit located at approximately anterior one-fifth of HL. Eye diameter only slightly larger than width of anterior nares. Interorbital width approximately $0.40-0.42$ of HL. Anterior narial opening circular, surrounded by very short, anteriorly-directed, tubular rim of skin. Opening of anterior nares located ventral of horizontal extending through tip of snout and approximately at horizontal running through maxillarybarbel origin. Distance between anterior nares equal to snout length. Posterior narial opening located on dorsal surface of snout and at horizontal extending through anterior margin of orbit; opening ovoid, with long axis of aperture aligned ob- 


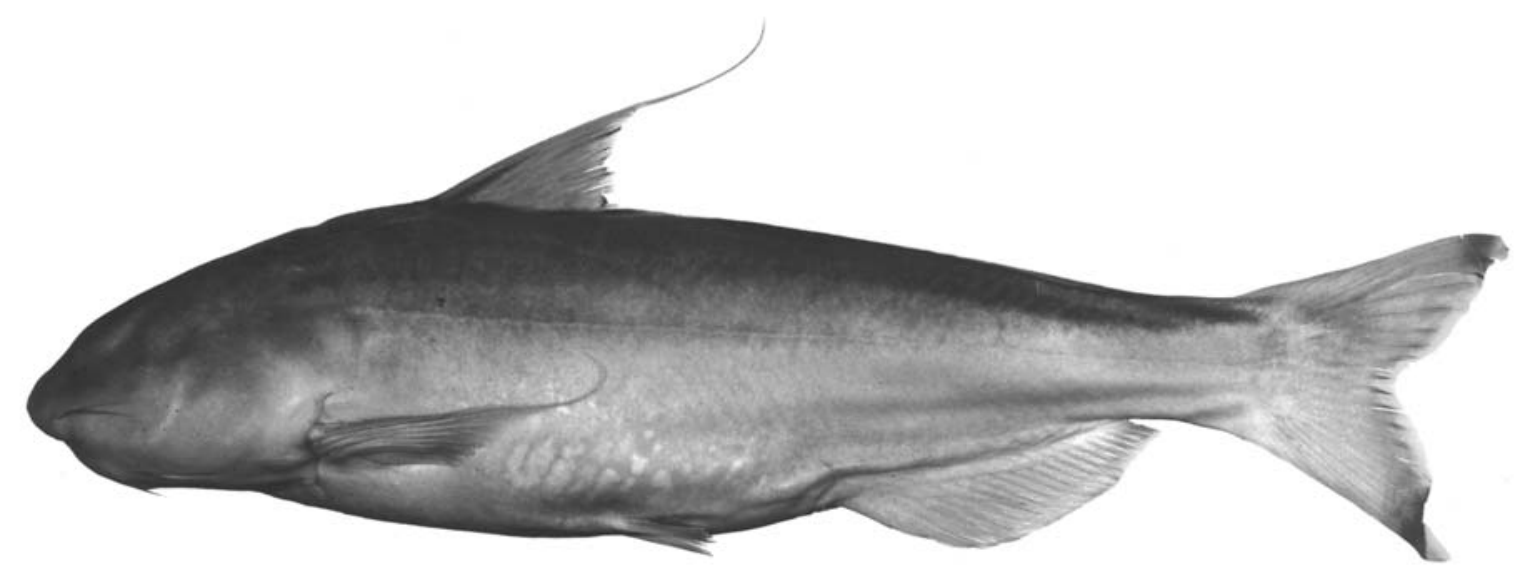

Fig. 18. Cetopsis coecutiens, MCNG 5262, 216 mm SL; Venezuela, Apure, río Sarare, between Las Bocas and Guasdualito $\left(7^{\circ} 11^{\prime} 50^{\prime \prime} \mathrm{N}, 71^{\circ} 48^{\prime} 10^{\prime \prime} \mathrm{W}\right)$.

lique to long axis of body. Anterior margin of posterior narial opening with low flap of skin. Distance between contralateral posterior nares only slightly larger than diameter of eye.

Mouth distinctly inferior; its width approximately equal to distance from tip of snout to posterior margin of orbit. Margin of lower jaw distinctly truncate, its posterior limit reaching to vertical through anterior margin of orbit. Premaxillary tooth patch elongate and continuous across midline; anterior margin convex and posterior margin concave. Premaxillary teeth relatively small, conical, sharply-pointed, and arranged in three irregular rows. Vomerine teeth very large, bluntly conical, and arranged in single, slightly-arched, transverse row. Dentary with single row of large, conical teeth approximately equal in number to, but 1.5 to 2.0 times size of, vomerine teeth.

Maxillary barbel very slender and short, its length approximately equal to distance from tip of snout to posterior margin of orbit; barbel origin located slightly anterior of vertical through anterior margin of orbit. Mental barbels approximately equal in size and length to maxillary barbel and to each other. Medial mental-barbel origin located just posterior of vertical through posterior margin of orbit. Lateral mental-barbel origin situated along vertical extending approximately one orbital diameter posterior of orbital margin. Tips of adpressed mental barbels falling distinctly short of posterior margin of opercle.

Dorsal fin relatively large overall with length of base of dorsal fin slightly less than one-half of HL. Length of longest branched dorsal-fin ray approximately two-thirds of HL. Dorsal-fin spinelet absent. First dorsal-fin ray not spinous, but with distal filament becoming progressively longer ontogenetically in both sexes; filament very well developed in largest specimens. Distal margin of dorsal fin slightly concave, with first ray longest. Dorsal-fin origin located at anterior one-third of SL and along vertical through middle of adpressed pectoral fin. Tip of adpressed dorsal fin, excluding distal filament on first fin ray, reaching to vertical through pelvic-fin insertion. Tip of distal filament of adpressed dorsal fin reaching to vertical through anal-fin origin. Posterior most dorsal-fin ray without posterior, membranous attachment to body.

Caudal fin deeply-forked, symmetrical; tips of lobes acutely pointed. Length of longest caudal-fin ray approximately two times length of middle fin rays.

Base of anal fin comparatively short, approximately onefourth of SL. Anal-fin origin located posterior of middle of TL. Anal-fin margin straight in females and immature males, with posterior most unbranched ray longest and lengths of subsequent rays becoming gradually shorter. Anal-fin margin in mature males slightly convex along anterior three-fourths of fin and then slightly concave along posterior five or six rays thereby giving appearance of slight lobe in anterior portion of fin. Posterior most anal-fin ray without posterior, membranous attachment to body.

Pelvic fin short, truncate, with distal margin nearly straight and first ray longest. Pelvic-fin insertion located approximately at middle of SL and entirely posterior to vertical through posterior terminus of base of dorsal fin. Tip of adpressed pelvic fin falling short of vent by distance approximately equal to length of first pelvic-fin ray. Medial most pelvic-fin ray with membranous attachment to body for basal one-half of its length.

Pectoral-fin length approximately two-thirds of HL. Pectoral-fin margin concave anteriorly and convex along posterior four rays. First pectoral-fin ray not spinous, but with distal filament; filament proportionally much longer in larger specimens. Tip of filament in adpressed dorsal fin reaching beyond vertical through pelvic-fin insertion in large individuals.

Coloration in alcohol. Head in medium to larger-sized specimens dusky dorsally with darker pigmentation becoming progressively diffuse ventrally. Smaller specimens with indistinct dusky band extending across interorbital region and with snout very pale. Body dusky dorsally, lighter ventrally, with relatively distinct ventral limit to field of dusky body pigmentation. Demarcation between dark and light pigmentation located dorsal to lateral line in examined specimens of all sizes. 
Dorsal fin with dark pigmentation present on interradial membrane between first and second branched rays and with remainder of fin pale. Pectoral fin pale other than for dark pigmentation on interradial membrane between first and second rays. Pattern of darker pigmentation on dorsal and pectoral fins more pronounced in larger specimens. Caudal, anal, and pelvic fins without pronounced dark pigmentation.

Barbels pale to dusky.

Coloration in life. Overall coloration as in preserved specimens, but with light silvery-blue sheen on head and body.

Sexual dimorphism. The first rays of the dorsal- and pectoral-fin rays of both sexes of Cetopsis coecutiens have elongate, distal filaments that do not appear to demonstrate sexual dimorphism in relative length. The females and immature males have a straight anal-fin margin, whereas mature males have a largely convex fin, albeit with a slightly concave margin along its posterior portion (see description of form of anal fin above).

Distribution. Cetopsis coecutiens is broadly distributed through the Amazon basin in Bolivia, Brazil, Colombia, Peru, and Venezuela, and also inhabits the rio Tocantins basin in Brazil, and the río Orinoco basin in Colombia and Venezuela (Fig. 19).

Common name. Brazil, rio Tocantins: "Candiru," "Piracatinga" (Mendez dos Santos et al., 1984: 78), rio Madeira: "Candiruaçú (Goulding, 1981:31); Colombia: "Bagre ciego" (Cala, 1977: 11); Peru: "Canero" (Ortega \& Vari, 1986: 15); Venezuela: "Bagre ciego" (Mago-Leccia, 1970: 82).

Remarks. Lichtenstein (1819: 61) based his description of Silurus coecutiens on two specimens. One of the two syntypes of the species was listed in both the original catalogue of ZMB and also in the second catalogue of that museum (that was started around 1860) wherein it was cataloged as ZMB 3093 (H.-J. Paepke, ZMB; pers. commun., 1998). Recent searches through the ZMB collections failed to yield the syntype and that specimen is apparently no longer extant (H.-J. Paepke, ZMB; pers. commun., 1998). The second syntype was offered for sale by Lichtenstein (1823: 112) and there is no record of the disposition of that specimen.

The material that served as the basis of the description of Silurus coecutiens originated in Brazil (Lichtenstein, 1823: 112). According to the $Z M B$ catalogues the syntypes were collected by an individual named Sieber, whose collecting efforts were limited to the area of Belém, Pará, Brazil (H.-J. Paepke, ZMB; pers. commun., 1998), a region within the general known distributional range of Cetopsis coecutiens. Despite the apparent loss of both of the syntypes of the species, the distinctive features of Silurus coecutiens (the Cetopsis coecutiens of this study) detailed by Lichtenstein (1819: 61) make it clear that the name is appropriately applied to the material herein identified as that species.

The distributional range of Cetopsis coecutiens is by far the greatest of any species within the Cetopsinae and it is the only species in the subfamily with a broad distribution across both the rio Amazonas and río Orinoco basins. Despite this broad geographic distribution, detailed comparisons failed to reveal any meristic or coloration differences between the samples from those two drainage systems that would justify the subdivision of the C. coecutiens of this study into more than one species.

Mendez dos Santos et al. (1984: 78) cited Cetopsis cf. caecutiens from the lower portions of the rio Tocantins ba$\sin$. Our results indicate that $C$. coecutiens is the only species that both occurs in that portion of the river basin and is likely to be cited as C. cf. caecutiens and we consider this citation to represent a record of the latter species.

Pozzi (1945: 262) followed by Ringuelet \& Arámburu (1961: 46), Ringuelet et al. (1967: 348) and López et al. (2003: 37) cited Cetopsis coecutiens from northwestern Argentina The original Pozzi report (1945, map on page 251) indicated two localities in the Provinces of Salta and Jujuy from which species of the Cetopsinae originated, with both of those sites within the río Bermejo basin in the northwestern portion of the río de La Plata drainage system. None of the specimens of Cetopsis coecutiens examined in this study originated in the río de La Plata basin and the only species of the Cetopsinae that we examined that originated in the río Bermejo system was $C$. starnesi. Because of this evidence, we consider the citations of Cetopsis coecutiens from Argentina to be based on misidentifications of another species, most likely C. starnesi.

Material examined. 268 specimens (23-264 mm SL). Indefinite locality: Between the mouth of the rio Negro and the Peruvian Amazon or Ucayali River," ANSP 8384, 1 (135). Bolivia. Riberalta, lago Tumi Chacua, near río Beni (approximately 1059'S, 6606'W), ANSP 121606, 1 (90). Beni: río Mamoré, 5 km SW Buena Hora (=Boa Hora: $\left.11^{\circ} 41^{\prime} \mathrm{S}, 65^{\circ} 05^{\prime} \mathrm{W}\right)$, Brazil, AMNH 55423, 1 (127). Río Mamoré, Trinidad (14²7'S, 64²7’W), MNHN 1988-1996, 1 (193). Brazil. Acre: Município de Artdira, rio Acre and marginal lagoons, LIRP 589, 3 (128188). Amapá: Fazendinha, rio Amazonas, near to Macapá $\left(0^{\circ} 02^{\prime} \mathrm{N}, 51^{\circ} 03^{\prime} \mathrm{W}\right)$, MNRJ 16933, 3 (57-99). Amazonas: rio Madeira, AMNH 3870, 1 (218). At mouth of rio Putomayo (=rio Içá; approximately $\left.3^{\circ} 05^{\prime} \mathrm{S}, 67^{\circ} 57^{\prime} \mathrm{W}\right)$, CAS 65903, 1 (147). Paraná de Janauaca (3⒉ 'S, $\left.60^{\circ} 17^{\prime} \mathrm{W}\right)$, USNM 217362, 5 (175-195); MCZ 99231, 9 (166-264). Lago Januacá (325'S, 61²2 'W), MZUSP 24915, 1 (139). Rio Amazonas, Itacoatiara ( $3^{\circ} 08^{\prime} \mathrm{S}$, $\left.58^{\circ} 25^{\prime} \mathrm{W}\right)$, MHNG 2582.75, 1 (195). Fonte Boa, igarapé Jacaré, near Fonte Boa, MZUSP 23354, 1 (113; specimen cleared and

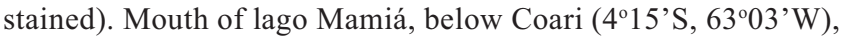
MZUSP 23252, 4 (132-168). Rio Madeira, Borba (4²4'S, 59³ 'W), MZUSP 28248, 1 (154). Rio Juruá, Carauari (452'S, 66 $54^{\prime}$ 'W), MZUSP 30697, 1 (127); MZUSP 30692, 1 (86). Rio Madeira, Aripuanã (=Nova Aripuanã) (506'S, 60²2'W), MZUSP 30695, 1 (115). Near Furo do Auozal, MZUSP 7401, 1 (190). Rio

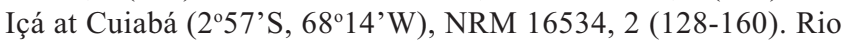
Uaupés at Taracuá (=Taraquá; $0^{\circ} 06^{\prime} \mathrm{N}, 68^{\circ} 28^{\prime} \mathrm{W}$ ), NRM 17132, 1 (173); NRM 25551, 1 (195); NRM 25552, 1 (218). Rio Uaupés at Jauareté (=Iaureté) $\left(0^{\circ} 36^{\prime} \mathrm{N}, 69^{\circ} 12^{\prime} \mathrm{W}\right), \mathrm{NRM} 25554,1$ (183).

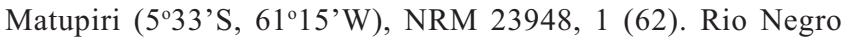
drainage (locality information questionable), NRM 25555, 1 (190). 
Rio Negro, 10.4 km below rio Demimi ( $1^{\circ} 13^{\prime} 01$ "S, 62 $\left.{ }^{\circ} 14^{\prime} 29^{\prime \prime} \mathrm{W}\right)$, MZUSP 55687, 1 (37). Rio Negro, $6.5 \mathrm{~km}$ below Jufari (1 ${ }^{\circ} 17^{\prime} 37^{\prime \prime S}$ 6156'57"W), MZUSP 55647, 8 (48-78). Rio Negro, near Baia do Cuieirus, MZUSP 38765, 6 (2 specimens, 107-128 mm, cleared and stained). Rio Purus, $24.3 \mathrm{~km}$ below paraná de Ananás, MZUSP 55697, 4 (122-163). Rio Solimões, $60 \mathrm{~km}$ above paraná do Barrosa (3¹1'59"S, 5954'27"W), MZUSP 57770, 2 (31-76). Rio

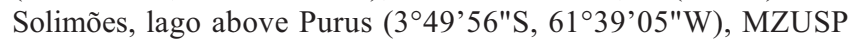
57340, 1 (46). Rio Purus, Caitaú, MZUSP 30443, 1 (97). Rio Solimões, $25 \mathrm{~km}$ below paraná de Amaturá ( $3^{\circ} 10^{\prime} 48^{\prime \prime S}$, $\left.67^{\circ} 55^{\prime} 40^{\prime \prime} \mathrm{W}\right)$, MZUSP 55682, 1 (28). Rio Solimões, $20 \mathrm{~km}$ below Içá $\left(3^{\circ} 00^{\prime} 45^{\prime \prime S}, 67^{\circ} 52^{\prime} 42^{\prime \prime W}\right)$, MZUSP 55684, 1 (25). Rio Solimões, $15 \mathrm{~km}$ below paraná Iranduba ( $\left.3^{\circ} 14^{\prime} 22^{\prime \prime} \mathrm{S}, 59^{\circ} 53^{\prime} 53^{\prime \prime W}\right)$, MZUSP 55646, 2 (23-30). Goiás: rio Tocantins between Porto de Garimpo and Foz do rio Preto, MHNG uncataloged (field number BR 954), 1 (215). Rio Tocantins between site of future dam of Usina Hidroeléctrica Cana Brava and Ilha, MNRJ 12907, 1 (198). Município de Minaçu/Cavalcante, rio Tocantins, at site of future dam of Usina Hidroeléctrica Serra da Mesa (1350'S, 48¹9'W), MNRJ 13235, 2 (200-264). Rio Vermelho, above Aruanã (approximately $14^{\circ} 54^{\prime} \mathrm{S}, 51^{\circ} 05^{\prime} \mathrm{W}$ ), MZUSP 38826,1 (220). Rio Araguaia, Aruanã (approximately $14^{\circ} 54^{\prime} \mathrm{S}, 51^{\circ} 05^{\prime} \mathrm{W}$ ), MZUSP 4863, 1 (240). Matto Grosso: rio Araguaia, lago Dumbá Grande, MZUSP 24819, 3 (168-197). Rio Araguaia, lago Montario, MZUSP 54176, 1 (202). Rio Araguaia, near Ilha do Biratã, MZUSP 62518, 1 (162). Pará: no specific locality, CAS-SU 22197, 1 (182). Rio Tocantins, in front of Tucuruí ( $\left.3^{\circ} 42^{\prime} \mathrm{S}, 4^{\circ} 27^{\prime} \mathrm{W}\right)$, MZUSP 24177, 2 (183, other specimen cleared and stained and disarticulated). Rio Tocantins, from immediately below to $3 \mathrm{~km}$ below Tucuruí reservoir (342’S, 49²7’W), MZUSP 61996, 1 (179). Rio Xingu, Belo Monte ( $\left.3^{\circ} 10^{\prime} \mathrm{S}, 51^{\circ} 50^{\prime} \mathrm{W}\right)$, MZUSP 59092, 4 (173-237). Rio Amazonas, Maiacuru (2 ${ }^{\circ} 14^{\prime}$ 'S, $\left.54^{\circ} 17^{\prime} \mathrm{W}\right)$, MNRJ 9395, 15 (73-120). Santarém (2²6’S, 54²'’W), FMNH 69823, 1 (191). Rio Trombetas, mouth of lago Jacaré, Reserva Biologica de Trombetas, MZUSP 15511, 1 (170). Mouth of lago Jacaré, Reserva Biologica de Trombetas, MZUSP 15533-34, 2 (177-180). Praia do lago near mouth of lago Jacaré, Reserva Biologica de rio Trombetas, MZUSP 15826, 1 (195). Rio Trombetas, Oriximiná (145'S, 5552'W), MZUSP 5466, 1 (170). Rio Trombetas, mouth of lago Paru ( $\left.1^{\circ} 57^{\prime} \mathrm{S}, 55^{\circ} 52^{\prime} \mathrm{W}\right)$, MZUSP 5685, 1 (97). Rio Tapajós, Ilha Tapaiúna (254'S, 5505'W), MZUSP 21985, 5 (179-192). Santana, Furo dos Macacos, MZUSP 23653, 1 (172). Abaetetuba, rio Tocantins ( $1^{\circ} 42^{\prime}$ 'S, 48 $\left.{ }^{\circ} 54^{\prime} \mathrm{W}\right)$, MZUSP 23945, 3 (109-130). Rio Tapajós, Maloquinha, MZUSP 24308, 2 (157-162). Rio Amazonas, Furo Ituquara below Gurupá (approximately $1^{\circ} 25^{\prime} \mathrm{S}$, 513'' 'W), MZUSP 43228, 12 (97-153); MZUSP 43288, 4 (143186). Ilha Urutaí, Município de Gurupá (approximately $1^{\circ} 25^{\prime}$ 'S, 51³9’W), MZUSP 9419, 1 (146). Rio Pará, Ilha do Camaleão (approximately 1³0'S, 4805'W), MZUSP 9474, 4 (113-153). Corcorado ( $1^{\circ} 51^{\prime}$ 'S, $\left.49^{\circ} 02^{\prime} \mathrm{W}\right)$, MZUSP 9475, 2 (144-158). Rio Amazonas, mouth of Furo do Aququi ( $1^{\circ} 35^{\prime}$ 'S, $\left.52^{\circ} 35^{\prime} \mathrm{W}\right)$, MZUSP 9491, 2 (107-123). Probably in vicinity of Belém, NRM 7102, 1 (137). Engenho Santo Antonio, Furo de Panaquera, MZUSP 23975, 8 (143-165; 1 specimen, $145 \mathrm{~mm}$, cleared and stained); ROM 37970, 3 (134-142). Rondônia: rio Madeira, Foz do Jamarí ( $8^{\circ} 45^{\prime}$ 'S, $\left.63^{\circ} 27^{\prime} \mathrm{W}\right)$, MZUSP 28370, 11 (154-205). Tocantins: rio Tocantins at Porto Nacional $\left(10^{\circ} 42^{\prime}\right.$ S, $48^{\circ} 25^{\prime}$ W), CAS 6609, 1 (218). Rio Tocantins, Município de Peixoto, MZUSP 45102, 2 (136-145). Colombia. Amazonas: Leticia, río Amazonas, ANSP 119877, 1 (93). Caqueta: río Orteguaza, MHNG 2526.66, 22 (106-120). Río Amazonas, Isla de Santa Sofia II, approximately $20 \mathrm{mi}(=32 \mathrm{~km})$ NW of Leticia, CAS 40714, 1 (117). Peru. Amazonas: río Santiago,
$1.5 \mathrm{~km}$ upstream of La Poza (latter locality at $4^{\circ} 01^{\prime} \mathrm{S}, 77^{\circ} 45^{\prime} \mathrm{W}$ ), LACM 39864-1, 1 (197). Río Marañon, Bagua, Ciro-Cenepa (4²4'S, 78¹0’W), MUSM 12494, 1 (195). Loreto: río Ambiyacu, ANSP 21533, 1 (135; originally cited in literature as from Ecuador). Río Ambiyacu, near Pebas (approximately $3^{\circ} 20^{\prime} \mathrm{S}, 71^{\circ} 49^{\prime} \mathrm{W}$ ), CAS SU 34225, 1 (101); CAS SU 36191, 1 (38). Rio Amazonas, INHS 38932, 1 (118). Río Napo, Puesto de Vigilancia Arcadia (059'S, 75¹8'W), MUSM 6023, 1 (210). Río Aguarico, Puesto de Vigilancia Castana (048'S, 75¹4'W), MUSM 6024, 1 (220). Madre de Dios: río Madre de Dios, Albergue Cuzco-Amazonico, CAS 59457, 2 (110-119). Río Madre de Dios, $2 \mathrm{~km}$ W of Puerto Maldonado (approximately 12³6'S, 69¹1'W), CAS 78929, 2 (121-176). Ucayali: río Ucayali, Pucallpa ( $\left.8^{\circ} 23^{\prime} \mathrm{S}, 74^{\circ} 32^{\prime} \mathrm{W}\right)$, MZUSP 26418, 1 (100). Venezuela. Río Orinoco, Puerto Cabrian to Puerto Morocota, 149-150 nautical mi (=276-277.8 km) from sea buoy, ANSP 152873, 1 (68). Amazonas: río Negro at San Carlos de río Negro ( $\left.1^{\circ} 58^{\prime} \mathrm{N}, 67^{\circ} 04^{\prime} \mathrm{W}\right)$, AMNH 74450,1 (185). Anzoátegui: Caño tributary to río La Pena, left bank tributary of río Orinoco, opposite Ciudad Bolivar (approximately $8^{\circ} 10^{\prime} \mathrm{N}$, $63^{\circ} 33^{\prime} \mathrm{W}$ ), ANSP 152872, 1 (31). Río Orinoco at Soledad boat launch just below Puente Angostura (approximately $8^{\circ} 10^{\prime} \mathrm{N}$, 633' W), ANSP 160997, 1 (51). Apure: río Apure, between mouth of río Portuguesa and San Fernando de Apure airport, ANSP 165235, 1 (137). Río Apure, above Apurito (756'20"N, 68²8'50"W), MCNG 11234, 1 (123). Río Sarare, between Las Bocas and Guasdualito ( $\left.7^{\circ} 11^{\prime} 50^{\prime \prime} \mathrm{N}, 71^{\circ} 48^{\prime} 10^{\prime \prime} \mathrm{W}\right)$, MCNG 5262, 2 (183-216). Río Apure, just W of Apurito, on S bank $\left(7^{\circ} 56^{\prime} \mathrm{N}\right.$, $\left.68^{\circ} 27^{\prime} \mathrm{W}\right)$, TNHC 13855, 2 (199-210). Delta Amacuro: río Orinoco, between Puerto Ordaz and Barrancas, AMNH 58156, 3 (56-104); AMNH 58156 SW, 1 (24.6, cleared and stained). Río Orinoco, near downstream end of Isla Muasimoina, 44 nautical $\mathrm{mi}(=81.5$ $\mathrm{km}$ ) from sea buoy $\left(8^{\circ} 36^{\prime} 36^{\prime \prime} \mathrm{N}, 60^{\circ} 45^{\prime} \mathrm{W}\right)$, USNM 265631, 1 (157). Río Orinoco channel, $\mathrm{N}$ of Isla Tres Caños, 128 nautical mi $(=237.1 \mathrm{~km})$ from sea buoy $\left(8^{\circ} 39^{\prime} \mathrm{N}, 61^{\circ} 58^{\prime} \mathrm{W}\right)$, USNM 265660 , 1 (28). Río Orinoco channel, at Puerto Ordaz, N of Islote Fajardo, 180 nautical mi $(=333.4 \mathrm{~km})$ from sea buoy $\left(8^{\circ} 23^{\prime} 33^{\prime \prime N}\right.$, 62³9'54"W), USNM 265673, 1 (34); LACM 43102-3, 2 (15-21, larger specimen cleared and stained). Río Orinoco tributary across from Isla Tres Caños, on N side of river, 131.8 nautical mi $(=224.1$ $\mathrm{km})$ from sea buoy $\left(8^{\circ} 39^{\prime} 48^{\prime \prime} \mathrm{N}, 62^{\circ} 01^{\prime} \mathrm{W}\right)$, USNM 265707, 1 (19). Río Orinoco, in deep channel ( $\left.8^{\circ} 23^{\prime} \mathrm{N}, 61^{\circ} 02^{\prime} \mathrm{W}\right)$, CAS $58079,6(102-170)$. Río Orinoco, in deep channel $\left(8^{\circ} 22^{\prime} \mathrm{N}\right.$, $\left.62^{\circ} 40^{\prime} \mathrm{W}\right)$, CAS 58161, 1 (33). Guarico: río Orinoco, at Laguna Isla Isabella, cross outlet of lagoon, 201 nautical $\mathrm{mi}(=372.3 \mathrm{~km})$ from sea buoy ( $\left.8^{\circ} 18^{\prime} \mathrm{N}, 63^{\circ} 56^{\prime} \mathrm{W}\right)$, USNM 265628, 30 (112-225; 1 specimen cleared and stained). Río Orinoco channel, between Puerto Ordaz and Ciudad Bolivar, 202 nautical mi $(=374.1 \mathrm{~km})$ from sea buoy $\left(8^{\circ} 18^{\prime} \mathrm{N}, 63^{\circ} 56^{\prime} \mathrm{W}\right)$, USNM 265657, 2 (37-54). Portuguesa: río Portuguesa $\left(9^{\circ} 04^{\prime} 00^{\prime \prime} \mathrm{N}, 69^{\circ} 30^{\prime} 00^{\prime \prime} \mathrm{W}\right), \mathrm{MCNG}$ 15775, 3 (185-192).

\section{Cetopsis fimbriata, new species \\ Figs. 19, 20, Tables 9-15}

Pseudocetopsis amphiloxa [not of Eigenmann, 1914].-de Pinna \& Vari, 1995: 2, fig. 2 [illustrated].

Diagnosis. Cetopsis fimbriata can be distinguished from all of its congeners by the combination of the presence of an eye, a conical teeth on the vomer and dentary, the rounded 


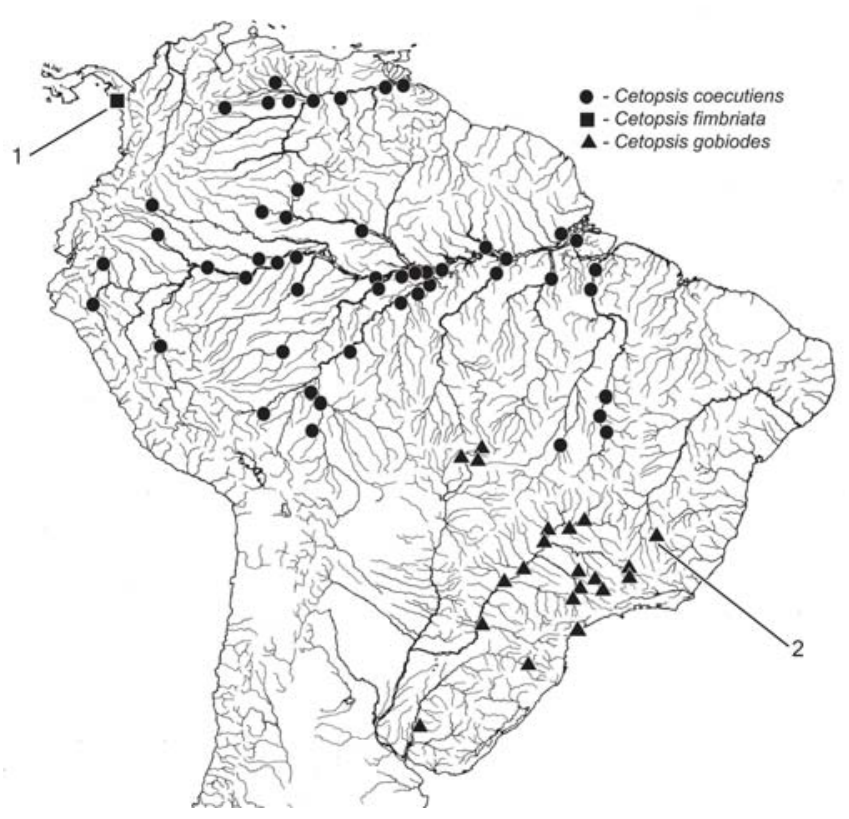

Fig. 19. Map of central and northern South America showing geographic distribution of Cetopsis coecutiens (type locality inexact $=$ Brazil $)$, Cetopsis fimbriata $(1=$ holotype locality $)$, and Cetopsis gobioides $(2=$ lectotype locality of Cetopsis chalmersi) (some symbols represent more that one locality and/or lot of specimens).

posterior nares that is distinctly separated from the contralateral nares by a distance greater than the width of the posterior nares, the presence of a dark, distal, margin along the anal fin, the dark distal margin of the pectoral fin, the absence of a dark humeral spot, the absence of a posteriorly-rounded, variably-developed, bilobed patch of dark pigmentation at the base of the caudal fin, and the presence of 46 to 48 total vertebrae, 25 to 28 total anal-fin rays, and 20 to 22 branched anal-fin rays.

Description. Body somewhat deep, slightly-compressed laterally anteriorly, becoming increasingly compressed posteriorly. Body depth at dorsal-fin origin equal to HL and slightly less than 0.25 of SL. Lateral line on body complete, unbranched, and midlateral; extending from vertical through pectoral-fin base onto hypural plate and terminating prior to posterior margin of hypural plate. Dorsal profile of body slightly convex and distinctly inclined from nape to dorsalfin origin; nearly straight from dorsal-fin origin to caudal-fin base. Ventral profile of body slightly convex along abdomen, approximately straight, but posterodorsally slanted along base of anal fin. Caudal-peduncle depth slightly less than caudal-peduncle length.

Head triangular in lateral view and broadly rounded anteriorly. Dorsal profile of head convex from tip of snout to vertical through posterior nares and slightly convex from that point to posterior of nape. Ventral profile of head gently con- vex. Profile of snout in dorsal view obtusely triangular overall and rounded at tip. Portion of head posterior of nares with lateral profiles running nearly in parallel from dorsal view. Dorsal surface of posterior portion of head without externally apparent enlarged jaw musculature.

Opercular membrane attaching to isthmus until point slightly anterior of vertical through pectoral-fin insertion. Opercular opening relatively wide; extending ventral of pectoral-fin insertion by distance approximately equal to distance from tip of snout to middle of eye and extending dorsal of pectoral-fin insertion by distance approximately equal to snout length.

Eye situated on lateral surface of head; located entirely dorsal to horizontal extending through pectoral-fin insertion; eye visible in dorsal view, but not in ventral view, of head. Middle of orbit at slightly less than anterior one-fourth of HL. Eye diameter approximately two-thirds of snout length. Interorbital width approximately equal to distance from tip of snout to posterior margin of orbit. Anterior narial opening circular, surrounded by short, anteriorly-directed, tubular rim of skin. Opening of anterior nares located at horizontal extending through both tip of snout and through maxillary-barbel origin. Distance between anterior nares approximately equal to distance between anterior and posterior nares, and approximately equal to snout length. Posterior narial opening large and located near dorsal profile of head dorsal to anterior onehalf of orbit; opening ovoid, with long axis of aperture aligned perpendicular to long axis of body, and with anterior two-thirds of opening bordered by flap of skin. Distance between posterior nares slightly less than distance between anterior nares.

Mouth inferior; its width approximately one-half of HL. Margin of lower jaw broadly rounded, its posterior extent reaching slightly beyond vertical through middle of eye. Premaxillary tooth patch elongate, continuous across midline; anterior margin convex, posterior margin concave and running in parallel to anterior margin. Premaxillary teeth of moderate size, conical, and sharply-pointed, with teeth arranged in three rows along entire tooth patch. Teeth of anterior premaxillary tooth row slightly smaller than those of other two tooth rows. Vomerine teeth arranged in continuous, anteriorly-convex row. Vomerine teeth bluntly conical and distinctly larger than premaxillary teeth. Dentary dentition consisting of two series of teeth. Primary dentary tooth row consisting of uniformly-sized, conical teeth approximately of same size as those on vomer. Second row of dentary teeth less extensive than anterior row and consisting of 5 or 6 shorter teeth extending laterally from each side of symphysis.

Maxillary barbel slender, its length distinctly greater than distance from tip of snout to posterior margin of orbit and nearly equal to one-half of HL; barbel origin located near vertical through anterior margin of orbit. Mental barbels approximately equal in size and length and slightly shorter than maxillary barbel. Medial mental-barbel origin located along vertical through posterior margin of orbit. Lateral mental-barbel origin situated slightly posterior of vertical through posterior margin of orbit. Tips of adpressed mental barbels reaching to, or beyond, posterior margin of opercle. 


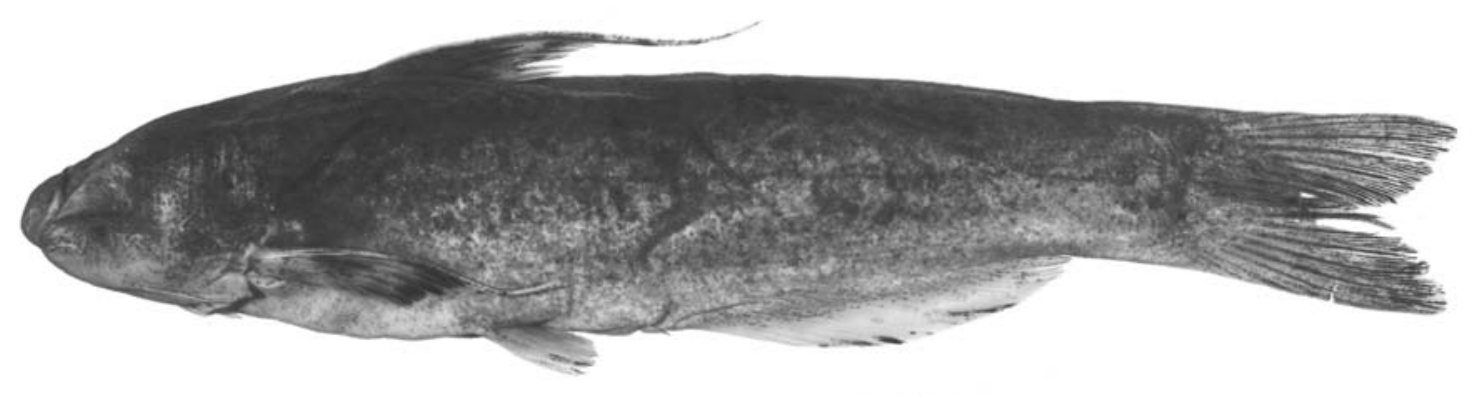

Fig. 20. Cetopsis fimbriata, new species, holotype, mature male, USNM 305348, 83 mm SL; Colombia, Choco, Creek of upper río Nercua, large tributary of río Truando (approximately $7^{\circ} 01^{\prime} \mathrm{N}, 77^{\circ} 30^{\prime} \mathrm{W}$ ).

Dorsal fin moderately large overall with length of dorsalfin base approximately $0.44-0.49$ of HL and slightly longer than distance from tip of snout to posterior margin of orbit. Longest dorsal-fin ray, excluding distal filament, equal to threequarters of HL. Dorsal-fin spinelet absent. First dorsal-fin ray not spinous, with short distal filament in females and immature males and with long distal filament in mature males. Distal margin of dorsal fin distinctly concave, with first ray longest. Dorsal-fin origin located slightly short of one-third of SL and along vertical through middle of adpressed pectoral fin. Tip of adpressed dorsal fin, excluding distal filament, reaching to vertical through anterior one-quarter of base of anal fin. Posterior most dorsal-fin ray without posterior, membranous attachment to body.

Caudal fin moderately-forked, symmetrical; tips of lobes slightly rounded. Length of longest caudal-fin ray slightly more than 1.5 times length of middle fin rays.

Base of anal fin moderate, approximately one-third of SL. Anal-fin origin located distinctly posterior of middle of SL. Anal-fin margin straight in immature males and presumed females, with posterior most unbranched anal-fin ray longest and subsequent rays gradually becoming shorter. Anal-fin margin in mature males convex, with rays of central portion of anal fin slightly longer than rays situated more both anteriorly and posteriorly. Posterior most anal-fin ray with posterior, membranous attachment to body for basal one-fifth of its length.

Pelvic fin moderate, its distal margin slightly convex, with second branched ray longest. Tip of adpressed pelvic fin barely reaching middle of SL and falling slightly short of vent. Insertion of pelvic fin located along vertical through posterior terminus of base of dorsal fin. Medial most pelvic-fin ray with membranous attachment to body for basal two-thirds of its length.

Pectoral-fin length, excluding distal filament, approximately three-quarters of HL. Posterior margin of branched pectoralfin rays slightly concave, with first ray distinctly longest. First pectoral-fin ray not spinous; with only slight, fleshy, distal extension in females and immature males, but with distinct distal filament in adult males.

Coloration in alcohol. Very dusky over most of head and body, becoming progressively lighter ventrally with overall pigmentation pattern often somewhat marmorated. Underside of head and abdomen without dark pigmentation.

Dorsal fin dark both basally and along entire length of first unbranched and first branched rays. Variably-developed, dark pigmentation present on distal portions of other dorsalfin rays. Dark pigmentation of body continues onto base of anal fin, with remainder of anal fin hyaline other than for irregular but very dark pigmentation present along distal portions of fin. Distal chromatophores form distinct, dark, distal margin to anal fin of some specimens. Caudal fin dusky with some irregularity to pattern. Pelvic fin with scattered, dusky pigmentation along base and along first ray. Pectoral fin with dark pigmentation on dorsal surface of base and variable dark pigmentation on distal portions of fin. Darkly pigmented individuals with dark subterminal band on pectoral fin.

Maxillary barbels dusky for basal one-half, pale distally. Mental barbels with few scattered, dark pigmentation spots near base.

Sexual dimorphism. Mature males of Cetopsis fimbriata have very elongate filaments on the distal portions of the first rays of the dorsal and pectoral fins; with such extensions distinctly more well developed than are the filaments that are present in conspecific females. The anal-fin margin in mature males of $C$. fimbriata is convex, contrary to the straight margin of the fin that is present in all examined females and immature males of the species.

Distribution. Cetopsis fimbriata is apparently endemic to the río Nercua, a tributary of the río Truando that flows into the río Atrato basin of the Caribbean Sea versant of northwestern Colombia (Fig. 19).

Etymology. The species name, fimbriata, from the Latin for fringed, refers to the dark pigmentation along the distal portion of the anal fin that characterizes this species.

Remarks. It is uncertain whether the citation of Hemicetopsis amphiloxa from the río Atrato system by Mojica-C. (1999: 565) referred to Cetopsis amphiloxa or to C. fimbriata, or a combination of those two species. Both of these species occur within the río Atrato basin, albeit in distinctly separate 
portions of that drainage system. In the absence of information as to the locations within the río Atrato basin from which the specimens examined by Mojica-C. (1999) originated, it is premature to associate that citation with a particular species.

Material examined. 57 specimens (49-103 mm SL). Holotype. Colombia. Choco: Creek of upper río Nercua (approximately $\left.7^{\circ} 01^{\prime} \mathrm{N}, 77^{\circ} 30^{\prime} \mathrm{W}\right)$, large tributary of río Truando, H. G. Loftin et al., 28 August 1957, USNM 305348, 1 (83, male). Paratypes. 8 specimens (70-87 mm SL). Colombia. Choco: Creek of upper río Nercua (approximately $7^{\circ} 01^{\prime} \mathrm{N}, 7^{\circ} 30^{\prime} \mathrm{W}$ ), large tributary of río Truando, H. G. Loftin et al., 28 August 1957, USNM 372825, 4 (70-84, all mature males); USNM 372826, 2 (73-87, cleared and stained); ICN-MHN 7272, 2 (74-76, both mature males). Nontype specimens. 48 specimens (49-103 $\mathrm{mm} \mathrm{SL})$. Colombia. Choco: Quebrada near río Nercua ( $\left.7^{\circ} 11^{\prime} \mathrm{N}, 7^{\circ} 33^{\prime} \mathrm{W}\right)$, USNM 257763, 47 (49-103, 2 specimens, 84-99 mm, cleared and stained). Quebrada Barrial, tributary of río Nercua $\left(7^{\circ} 06^{\prime} \mathrm{N}, 77^{\circ} 32^{\prime} \mathrm{W}\right)$, USNM 295647 , $1(50)$.

\section{Cetopsis gobioides Kner, 1857}

Figs. 19, 21, 22, Tables 9-15

Cetopsis gobioides Kner, 1857: 407, fig. 16 [(type locality: Brazil), Irisanga].-Günther, 1864: 199 [(Brazil), Irisanga, based on Kner, 1857].-Eigenmann \& Eigenmann, 1888: 157 [in listing of Cetopsis species]; 1890: 322 [in listing of Cetopsis species]; 1891: 36 [in listing of Cetopsis species].-[not Perugia, 1897: 23; Fowler, 1940b: 97].

Silurus pygmaeus.-Natterer, in Kner, 1857: 408 [nomen nudum].

Pseudocetopsis gobioides.-Bleeker, 1862a: 403 [assignment to, and designation as type species of, Pseudocetopsis; brief redescription]; 1862b: 16 [brief redescription]; 1863: 111 [brief redescription].-Eigenmann, 1910: 398 [distribution; not (río) Marañon citation].-Miranda-Ribeiro, 1912: 378 [Brazil, Irizanga; redescription]; 1918: 735 [Brazil: Minas Gerais, rio Sapucahy, Pouso Alegre; Piracicaba].Eigenmann \& Allen, 1942: 149 [in listing of species, not citation of species in region from "both sides of Ecuadorean Andes to Central Brazil"].-Bertoni, 1939: 51 [Paraguay, Puerto Bertoni].-Gosline, 1945: 54 [distribution].-Fowler, 1954: 3, fig. 592 [literature compilation].Ringuelet \& Arámburu, 1961: 46 [Argentina].-Alonso de Arámburu et al., 1962: 237 [Argentina: Corrientes].Ringuelet et al., 1967: 349, fig. 32a [Argentina, Corrientes; not citation of species from Alto Amazonas].-Britski, 1972: 97 [Brazil, state of São Paulo].-Ringuelet, 1975: 63 [Argentina, río Paraná and río Paraguay].-Braga \& Azpelicueta, 1986: 87 [Argentina, Provincia de Misiones, río Paraná between Isla Sarandí and Pozo Heller].-Burgess, 1989: 291 [in listing of species].-Oliveros \& Rossi, 1992: 77 [Argentina, río Colastiné].-Bennemann et al., 1995: 11 [Brazil, Paraná, rio Tibagi].--Gómez \& Chebez, 1996: 61 [Argentina, Misiones, río Paraná; common name].Pavanelli \& Caramaschi, 1997: 26 [Brazil, Paraná, rio Paraná, Porto Rico].-Britski et al., 1999: 115 [Brazil,
Pantanal].-Agostinho \& Júlio, 1999: 385 [Brazil, upper rio Paraná].-Nakatani et al., 2001: 256, fig. [eggs, larvae, juveniles].-Evers \& Seidel, 2002: 741 [listing].-López et al., 2003: 37 [Argentina, río Paraná system; rare species].Vari \& Ferraris, 2003: 259 [in check list; synonymy, distribution, common name].-[Not Castello, 1969: 407; López et al., 1984: 85].

Cetopsis chalmersi Norman, 1926: 116 [type locality: (Brazil) rio das Velhas, approximately 32 miles $(=51.2 \mathrm{~km})$ north of Belo Horizonte].-Fowler, 1954: 4 [Brazil, rio São Francisco].-Gosline, 1945: 54 [rio das Velhas, probably E of state of São Paulo].-Burgess, 1989: 292 [rio das Velhas, probably E of state of São Paulo].-Evers \& Seidel, 2002: 741 [listing].--Vari \& Ferraris, 2003: 259 [as synonym of Pseudocetopsis gobioides Kner].

Pseudocetopsis chalmersi.-Schultz, 1944: 252 [in key].Fowler, 1954: 4 [Brazil, rio São Francisco].-Travassos, 1960: 43 [Brazil, rio São Francisco].-Britski et al., 1984: 31 [Brazil, rio São Francisco].-Britski et al., 1986: 31 [Brazil, rio São Francisco].-Sato \& Godinho, 1999: 412 [Brazil, rio São Francisco].

Pseudocetopsis sp.-Bertoletti et al., 1989: 10 [Brazil, rio Grande do Sul, upper rio Uruguai].

Diagnosis. Cetopsis gobioides can be distinguished from all of its congeners by the combination of the presence of an eye, the conical teeth on the vomer and dentary, the rounded posterior nares that is distinctly separated from the contralateral nares by a distance greater than the width of the posterior nares, a mouth width that is approximately one-half of HL, the absence of a dark humeral spot, the absence of a posteriorly-rounded, variably-developed, bilobed patch of dark pigmentation at the base of the caudal fin, the absence of dark chromatophores on the anterior and lateral margins of the snout, the limitation of dark pigmentation on the dorsal fin to, at most, the basal regions of the middle portion of the fin in the form of spot with a semicircular margin, and the possession of 17 to 22 branched anal-fin rays, 22 to 27 total anal-fin rays, and 42 to 45 total vertebrae (see also under "Remarks" concerning the differences that discriminate $C$. gobioides from the very similar C. plumbea).

Description. Body typically relatively stout, but shallower in some individuals, somewhat laterally compressed anteriorly and becoming increasingly compressed posteriorly. Body depth at dorsal-fin origin approximately $0.24-0.25$ of SL, and approximately equal to HL. Lateral line on body complete, unbranched, and midlateral; extending from vertical through pectoral-fin base to hypural plate with short, dorsal bend on hypural plate. Dorsal profile of body straight and obliquelyslanted from nape to dorsal-fin origin, straight from dorsal-fin origin to caudal-fin base. Ventral profile of body straight to slightly convex along abdomen, approximately straight, but posterodorsally slanted, along base of anal fin. Caudal-peduncle depth approximately equal to caudal-peduncle length.

Head in lateral view acutely triangular, with bluntly- 


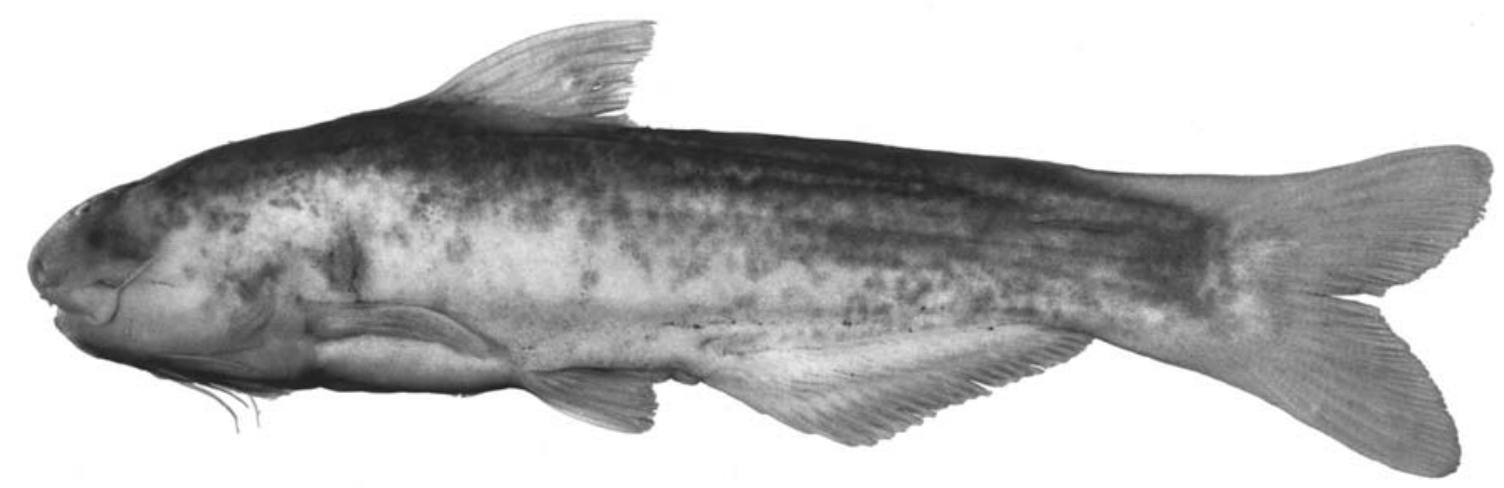

Fig. 21. Cetopsis gobioides, MZUSP 51539, 50 mm SL; Brazil, Minas Gerais, Fortuna de Minas, rio Paraopeba, Fazenda Chaparral.

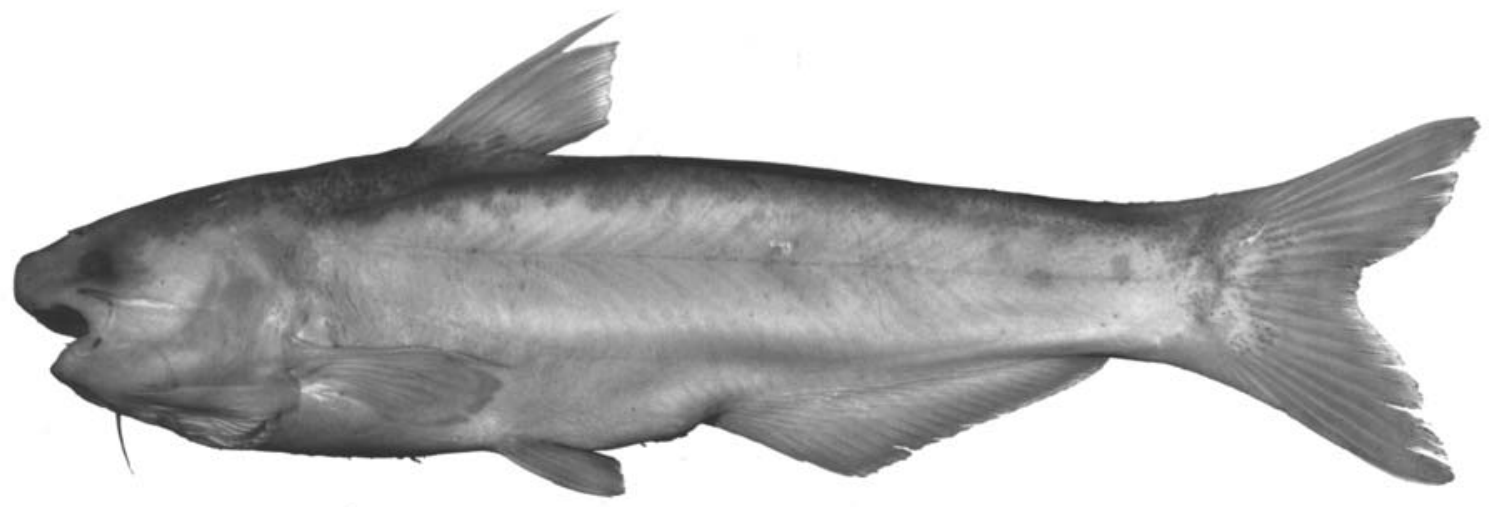

Fig. 22. Cetopsis gobioides, ITAIPU 57, 103 mm SL; Paraguay, upper río Paraná basin, Foz de Iguazu (25³3’S, 543’ ’W).

rounded snout. Dorsal profile of head broadly rounded from tip of snout to vertical through anterior margin of eye, slightly convex from that point to nape. Ventral profile of head convex. Profile of snout in dorsal view broadly rounded. Width of postorbital portion of head gradually increasing posteriorly. Dorsal surface of postorbital part of head with enlarged jaw musculature externally obvious but not pronounced.

Opercular membrane attaching to isthmus posteriorly as far as vertical through pectoral-fin insertion. Opercular opening moderate; extending ventral of horizontal running through pectoral-fin insertion for distance equal to snout length and dorsal of that level for distance slightly less than length of snout.

Eye situated on lateral surface of head; located slightly less than one orbital diameter dorsal of horizontal extending through pectoral-fin insertion; eye visible in dorsal view, but not in ventral view, of head. Middle of orbit at slightly less than anterior one-third of HL. Eye diameter approximately one-half of snout length. Interorbital width approximately equal to snout length. Anterior narial opening circular, surrounded by short, anteriorly-directed, tubular rim of skin. Opening of anterior nares located along horizontal extending through tip of snout and above horizontal extending through maxillarybarbel origin. Distance between anterior nares approximately equal to snout length. Posterior narial opening situated on dorsal surface of head, and along vertical through anterior margin of orbit; opening nearly rounded and without obvious long axis. Anterior two-thirds of narial opening bordered by approximately nearly uniformly-high flap of skin; flap only slightly higher anteriorly. Distance between contralateral posterior nares slightly less than distance between contralateral anterior nares.

Mouth inferior; its width approximately one-half of HL. Margin of lower jaw broadly rounded, its posterior limit reaching to vertical through middle of orbit. Premaxillary tooth patch elongate and crescentic, continuous across midline with anterior margin convex and posterior margin concave. Premaxillary teeth relatively small, conical, and sharply-pointed, with teeth in three or four, irregularly-arranged rows. Teeth near premaxillary symphysis larger than remaining teeth on premaxilla. Vomerine teeth large, bluntly conical, and in one to three irregularly-arranged, transversely-oriented, anteriorlyconvex rows; tooth rows continuous across midline. Number of tooth rows increasing ontogenetically. Posterior tooth row with irregularly-spaced teeth on each side of symphysis in smaller specimens. Dentary dentition consisting of three or four rows of teeth in region proximate to symphysis, with dentition progressively reduced to one tooth row along posterior one-half of jaw. Dentary teeth large and conical, with lateral teeth and largest medial teeth equivalent in size to largest teeth on premaxilla.

Maxillary barbel slender, its length approximately equal to 
distance from tip of snout to posterior margin of orbit; barbel origin located along vertical through anterior margin of orbit. Mental barbels approximately equal in size and length to maxillary barbel and to each other. Medial mental-barbel origin located along vertical through posterior margin of orbit. Origin of lateral mental barbel located slightly posterior of vertical through posterior margin of orbit. Tips of adpressed mental barbels falling short of posterior margin of opercle.

Dorsal fin moderately large overall with length of base approximately $0.43-0.47$ of HL. Longest dorsal-fin ray equal in length to distance from anterior margin of orbit to posterior margin of head. Dorsal-fin spinelet absent. First dorsal-fin ray not spinous; with short distal filament in females and moderate extension in single examined male with intact dorsal fin. Distal margin of dorsal fin straight, with first ray longest. Dorsal-fin origin located at approximately anterior one-third of SL and along vertical extending through middle of adpressed pectoral fin. Tip of adpressed dorsal fin, excluding distal filament, reaching to, or falling slightly short of, vertical through tip of adpressed pelvic fin. Posterior most dorsal-fin ray without posterior, membranous attachment to body.

Caudal fin deeply-forked and symmetrical; tips of lobes bluntly pointed. Length of longest caudal-fin ray approximately two times length of middle fin rays.

Base of anal fin relatively long, slightly less than onethird of SL. Anal-fin origin located well posterior of middle of SL and slightly anterior of middle of TL. Anal-fin margin straight in females and immature males, with first branched anal-fin ray longest and length of subsequent rays becoming gradually shorter. Anal-fin margin convex in two examined mature males. Posterior most anal-fin ray without posterior, membranous attachment to body.

Pelvic fin short, with distal margin slightly to distinctly convex and first branched ray longest. Pelvic-fin insertion located anterior to middle of SL and along vertical through posterior portion of base of dorsal fin. Tip of adpressed pelvic fin extending beyond middle of SL, and falling short of vent in most examined samples, but reaching to vent in some smaller specimens from rio Tocantins basin. Medial most pelvic-fin ray with membranous attachment to body along basal two-thirds of its length.

Pectoral-fin length approximately two-thirds of HL. Pectoral-fin margin convex with first ray longest. First pectoralfin ray not spinous and with short, distal filament in females and moderately long filament in single examined male with intact pectoral fin.

Coloration in alcohol. Body distinctly dark dorsally. Some specimens with marmoration along indistinct boundary between light and dark regions; boundary between those regions typically located dorsal to lateral line (Fig. 22), but extending in some darkly pigmented specimens ventral of lateral line in region dorsal to posterior portion of base of anal fin and also along caudal peduncle. Some individuals with eye-size, dark blotches scattered across base pigment pat- tern on dorsolateral portion of body (Fig. 21). Widely scattered, fine, dark pigmentation present to varying degrees on lateral surface of body. Ventral surface of abdomen pale. Postorbital portion of head distinctly dark dorsal to level of orbit. Snout distinctly lighter than postorbital region of head with at most few, dark chromatophores on dorsal surface of snout, but without such pigmentation on anterior and lateral surfaces of snout. Orbital region slightly darker than snout and lateral surface of head. Lateral and ventral surface of head pale, but not as dark as dorsal postorbital region of head.

Dorsal fin pale except for semicircular, dark spot present basally on middle rays of fin in some specimens. Pectoral and pelvic fins pale or with few, scattered spots of dark pigmentation. Anal fin pale with few, scattered spots of dark pigmentation basally in some specimens. Caudal fin with variably-developed, bilobed, dusky spot at base of fin and with scattered, dark pigmentation on dorsal lobe in some darkly pigmented specimens.

Barbels with scattered, dusky pigmentation basally and pale distally.

Coloration in life. Based on a transparency provided by F.A. Bockmann, LIRP, of a live male, now MNRJ 17008, collected in Município de Perdtes, rio Grande basin, upper rio Paraná system, Minas Gerais, Brazil, and photographed in an aquarium. Overall dark coloration as described above, but with fins hyaline other than for dark pigmentation at base of dorsal fin. Silvery sheen overlying lateral surface of head and body, with silvery coloration more intense on anterior twothirds of body.

Sexual dimorphism. The presumed mature males of Cetopsis gobioides have the distal filaments on the first rays of the dorsal and pectoral fin more elongate than are those structures in females and immature males of that species. Mature males of $C$. gobioides also have a convex anal-fin margin contrary to the straight margin of the fin that is present in females and immature males of the species.

Distribution. Cetopsis gobioides is known from the upper portions of the rio São Francisco basin in Brazil, and the rio Paraná and río Uruguay basins in Argentina, Brazil, Paraguay, and Uruguay, the upper rio Paraguay in Brazil, and the coastal rio Juquiá of the state of São Paulo, Brazil (Fig. 19).

Common Name. Brazil, rio São Francisco basin: "Candiruaçú" (Britski et al., 1984: 31); Argentina, Misiones: "Bagrecito," "Tiburoncito" (Gómez \& Chebez, 1996: 61).

Remarks. Cetopsis gobioides is very similar to C. plumbea, a species endemic to the western portions of the Amazon basin, in its overall head and body form, overall coloration, and meristic values. The two species are distinguishable in the lack of the dark chromatophores on the anterior and lateral surfaces of the snout in C. gobioides, versus the presence of such dark pigmentation in that region of C. plumbea. 
The distribution of dark pigmentation on the dorsal fin differs between the two species with such pigmentation forming at most a dark semicircular spot at the base of the fin in $C$. gobioides, versus a more extensive distribution of dark pigmentation across the fin with the first fin ray and associated interradial membranes darkly pigmented in C. plumbeus. The two species also have much different, albeit slightly overlapping ranges in the numbers of total vertebrae (see Table 15), with a broader interspecific overlap but different modes for the two species in the number of branched anal-fin rays (Table 10), total anal-fin rays (Table 11), precaudal vertebrae (Table 13), and caudal vertebrae (Table 14).

The original description of Cetopsis gobioides by Kner (1857: 407) was based on two syntypes that we were unable to examine. Nonetheless, the data and illustration in the original description and more importantly the fact that there only one species of the Cetopsinae is known to occur in the upper rio Paraná basin, the type drainage of the species, makes it clear that the material identified herein as $C$. gobioides is conspecific with that species.

In the original description of Cetopsis chalmersi, based on specimens from the rio São Francisco basin of eastern Brazil, Norman (1926: 116) compared his new species to $C$. occidentalis (=Paracetopsis bleekeri in this study). Paracetopsis bleekeri, however, is limited to the TransAndean portion of Ecuador, a considerable distance to the west of the type locality of Cetopsis chalmersi. Norman did not elaborate on the restriction of the comparison of $C$. chalmersi to C. occidentalis (=Paracetopsis bleekeri) to the exclusion of the geographically more proximate nominal species, C. gobioides, which was described by Kner (1857: 407) based on specimens collected at Irisanga, Brazil, a locality in the upper rio Paraná basin of Brazil. A comparison of numerous specimens of C. gobioides from the rio São Francisco and rio Paraná basins, including the type series of $C$. chalmersi, has failed to reveal any consistent differences between these two nominal forms (see also next paragraph). As a consequence Cetopsis chalmersi is herein considered to be a synonym of $C$. gobioides.

Although we were unable to identify any features useful in unequivocally separating populations of $C$. gobioides from the rio São Francisco and rio Paraná basin, there does occur a pronounced degree of intraspecific ontogenetic variation in the degree of development of the oral dentition among the population samples of what is herein considered C. gobioides. This variation does not, however, demonstrate any geographic pattern that supports the continued recognition of two species, but this question should be revisited once adequate population samples of the species from the rio São Francisco basin become available.

Norman (1926: 116) based his original description of Cetopsis chalmersi on three specimens collected by Chalmers. One of these (BMNH 1925.10.1.4) was examined in the course of this study and the other two syntypes (BMNH 1925.1.12.2-3) are still extant. We herein designate the examined syntype (BMNH 1925.10.1.4) as the lectotype of the spe- cies. In addition we examined a fourth specimen of the species (BMNH 1925.12.31.70) that appears to have collected at the same time and location as the type specimens but which apparently is not part of the type series.

Pseudocetopsis gobioides was cited from the río Bermejo in the Province of Salta, northwestern Argentina by Castello (1969: 407) and López et al. (1984: 85). Although Cetopsis gobioides is present in Argentina in the río Paraná basin of the northeastern portions of that country, we have not examined any specimens of that species from the northwestern region of Argentina. The only member of the Cetopsinae known to occur to the río Bermejo drainage is C. starnesi and the report of Pseudocetopsis gobioides from the río Bermejo is, thus, tentatively considered to be based on specimens of Cetopsis starnesi.

Material examined. 65 specimens $(61,28-110 \mathrm{~mm} \mathrm{SL})$. Argentina. Misiones: río Paraná, Puerto Iguazu (25³4'S, 54³4'W), MHNG 2389.14, 1 (98). Brazil. Mato Grosso: Município de Cuiabá, Chapada dos Guimarães, riacho tributary to rio Carlos Augusto, MZUSP 35217, 3 (60-91). Rio Araguari, Salto de Nova Ponte, Município de Nova Ponte, MZUSP 38564, 3 (2, 65-84; 1 specimen, $71 \mathrm{~mm}$, cleared and stained). Rio Araguari, Salto Ponte, Nova Ponte (approximately $18^{\circ} 21^{\prime}$ 'S, $48^{\circ} 40^{\prime} \mathrm{W}$ ), MZUSP 38825, 1 (96). Rio Acorizal, at bridge between Acorizal and Baus (15'12'10"S, 56²2'5"W), MNRJ 11305, 1 (47). Rio Paraná, Ilha Solteira, MZUSP 24455, 8 (7, 28-55, 1 specimen, 41 mm, cleared and stained). Córrego Água Lima, tributary of rio Abaeté, along road from Quirinos to Major Porto, MZUSP 39599, 1 (98; specimen cleared and stained); MZUSP 40217, 2 (1 specimen, 108 mm, cleared and stained). Riacho tributary to rio Carlos Augusto, on road of Fazenda da Cascata, Chapada dos Guimarães, MZUSP 35217, 3 (59.5-91). Mato Grosso do Sul: Alcinópolis, "riacho" near Córrego do Engano (18 $12^{\circ} 5^{\prime} \mathrm{S}$, 52 $2^{\circ} 2^{\prime} 43^{\prime \prime W}$ ), MZUSP 59355, 1 (31). Município de Jupiá, rio

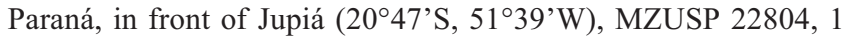
(109). Pouso Alegre, rio Sapucai (approximately $20^{\circ} 08^{\prime} \mathrm{S}, 48^{\circ} 27^{\prime} \mathrm{W}$ ), MZUSP 2313, 1 (89). Minas Gerais: rio das Velhas, approximately 20 miles $(=32 \mathrm{~km}) \mathrm{N}$ of Bello Horizonte (=Belo Horizonte), BMNH 1925.10.1.4, 1 (108, lectotype of Cetopsis chalmersi, designated herein); BMNH 1925.12.31.70, 1 (105). Fortuna de Minas, rio Paraopeba, Fazenda Chaparral, MZUSP 51539, 1 (50). Rio Cabo Verde, Alfenas (approximately $21^{\circ} 15^{\prime} \mathrm{S}, 45^{\circ} 47^{\prime} \mathrm{W}$ ), MZUSP 22762 , 3 (2, 97-106, 1 specimen, $106 \mathrm{~mm}$, cleared and stained). Gi-Mirim (=Poço Fundo), tributary of rio Machado $\left(21^{\circ} 48^{\prime} \mathrm{S}, 45^{\circ} 58^{\prime} \mathrm{W}\right)$, MNRJ 944, 2 (72-96). Rio Grande do Sul: Município de Maximiliano de Almeida, rio Forquilha along road between Maximiliano de Almeida and Machadinho, rio Uruguai basin (27 $\left.31^{\prime} \mathrm{S}, 51^{\circ} 49^{\prime} \mathrm{W}\right)$, MCP 13403, 1 (93). Santa Catarina: rio Uruguai, at Itá (27 $16^{\prime}$ 'S, 51¹9’W), MCP 13386, 1 (92; specimen cleared and stained). São Paulo: Município de Itú, Itú, rio Tietê, Fazenda Pau D'Olho

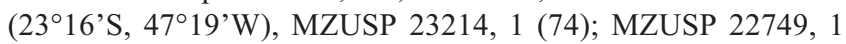
(88); MZUSP 22464, 1 (74). Piracicaba (22 $\left.{ }^{\circ} 03^{\prime} \mathrm{S}, 44^{\circ} 46^{\prime} \mathrm{W}\right)$, MZUSP 3095, 2 (87.5-92.5); MZUSP 2312, 2 (65-70). Lagoas along margin of rio Corumbataí ( $\left.22^{\circ} 14^{\prime} \mathrm{S}, 47^{\circ} 38^{\prime} \mathrm{W}\right)$, MZUSP 22760 ,

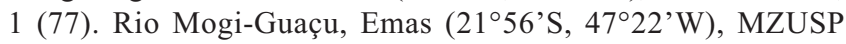
22945, 6 (50-92; 1 specimen, $77 \mathrm{~mm}$, cleared and stained). Rio Paraná, Ilha Solteira, MZUSP 23091, 8 (40- 79; 1 specimen, 61

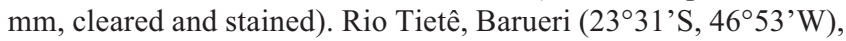
MZUSP 3209, 1 (80). Rio Turuo, km 27 along highway from São José do rio Preto to Olimpia, MZUSP 35420, 1 (70). Rio Paraná, 
Porto Castillo, $170 \mathrm{~km}$ below Porto Epitacio (22 $\left.2^{\circ} 15^{\prime} \mathrm{S}, 52^{\circ} 31^{\prime} \mathrm{W}\right)$, MZUSP 38760, 1 (98). Marginal lagoon of rio Juquiá, Registro, above fish farm of João Paca, MZUSP 36763, 1 (110). Rio Turro, tributary of rio Grande near São José do rio Preto, MZUSP 38808, 2 (1 specimen, $85 \mathrm{~mm}$, cleared and stained). Paraguay, upper río

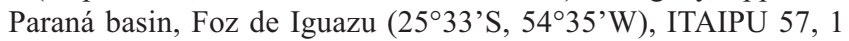
(103). Uruguay. Near junction of río Quequay and río Uruguay (3209'S, 5809’W), BMNH 1947.11.20.1, 1 (45).

\section{Cetopsis jurubidae (Fowler, 1944)}

Figs. 23-25, Tables 9-15

Pseudocetopsis jurubidae Fowler, 1944: 235, figs. 7-9 [type locality: Colombia, río Jurubidá, Nuquí].-Böhlke, 1984: 40 [holotype despository].-Vari and Ferraris, 2003: 258 [in check list; distribution].

Diagnosis. Cetopsis jurubidae can be distinguished from all of its congeners by the combination of the presence of an eye, the conical teeth on the vomer and dentary, the rounded posterior nares that is distinctly separated from the contralateral nares by a distance greater than the width of the posterior nares, the absence of a dark humeral spot, the lack of dark basal pigmentation on the middle portion of the dorsal fin, the absence of a posteriorly-rounded, variably-developed, bilobed patch of dark pigmentation at the base of the caudal fin, the lack of dark pigmentation on the distal portions of the anal and pectoral fins, and the possession of 9 pectoral-fin rays, 43 total vertebrae, 12 precaudal vertebra, 18 preanal vertebrae, 31 caudal vertebrae, 23 branched anal-fin rays, and 28 total anal-fin rays.

Description. Body relatively elongate, slightly transversely compressed anteriorly and becoming progressively distinctlycompressed posteriorly, but with relative degree of compression impossible to determine because of desiccation of only known specimen. Body depth at dorsal-fin origin approximately 0.25 of SL, and approximately equal to HL. Lateral line on body complete, unbranched, and midlateral; extending from vertical through pectoral-fin base onto hypural plate and terminating prior to posterior margin of hypural plate. Dorsal profile of body cannot be determined because of desiccation that specimen experienced at some point, but holotype illustrated (Fowler, 1944, fig. 8; reproduced herein as Fig. 24) with dorsal profile slightly convex from point slightly anterior to dorsal-fin origin to posterior of base of dorsal fin and nearly straight from that point to caudal peduncle. Caudal-peduncle depth approximately equal to caudal-peduncle length.

Head in profile acutely triangular overall with somewhat pointed snout, but with profile modified by noted desiccation of holotype and illustrated by Fowler (see Fig. 24) as more rounded. Dorsal profile of head nearly straight from tip of snout to nape. Ventral profile of head cannot be determined because of desiccation of specimen, but shown as nearly straight in drawing by Fowler (see Fig. 24). Margin of snout in dorsal view obtusely triangular overall and rounded anteriorly. Postorbital margins of head posteriorly divergent from dorsal view (see also Fowler, 1944, fig. 9). Condition of specimen makes it impossible to determine presence or absence of enlarged jaw musculature externally evident on dorsal surface of postorbital portion of head in some species of Cetopsinae.

Opercular membrane attaching to isthmus only to region anterior to vertical through pectoral-fin insertion. Opercular opening moderate; extending ventral of pectoral-fin insertion by distance equal to snout length and extending dorsal of pectoral-fin insertion by distance equal to width of orbit.

Eye situated on lateral surface of head; located entirely dorsal to horizontal extending through pectoral-fin insertion; eye visible in dorsal view, but not in ventral view, of head. Middle of orbit at approximately anterior one-fourth of HL. Eye diameter approximately equal to one-half of snout length. Interorbital width approximately equal to distance from tip of snout to posterior margin of orbit. Form of anterior narial opening cannot be evaluated because of desiccation of specimen. Opening of anterior nares located dorsal to horizontal extending through maxillary-barbel origin. Distance between anterior nares approximately equal to snout length. Posterior narial opening located on dorsal surface of head, situated along vertical through anterior margin of orbit; opening nearly round and nearly completely surrounded by flap of skin around anterior two-thirds of aperture and with anterior portion of flap highest.

Mouth inferior, apparently very wide in somewhat desiccated holotype; its width approximately one-half of HL. Margin of lower jaw gently rounded, its posterior limit reaching to vertical through posterior margin of orbit. Premaxillary tooth patch in form of gently-arched band continuous across midline, with anterior margin convex and posterior margin concave and running in parallel to anterior margin. Teeth on premaxilla small, conical, sharply-pointed, and arranged in three irregular rows (see also Fowler, 1944, fig. 7). Teeth of innermost premaxillary tooth row slightly larger than remaining teeth on that bone. Vomerine teeth conical and arranged in single row continuous across midline; tooth row extending transversely on medial portion of vomer and then curving posteriorly laterally. Vomerine teeth similar in form and size to largest teeth on premaxilla. Dentary teeth comparable in size and shape to premaxillary teeth, with two rows medially that taper to one row laterally (see also Fowler, 1944, fig. 7).

Maxillary barbel slender, its length slightly greater than distance from tip of snout to posterior margin of orbit, approximately 0.40 of HL; barbel origin located ventral to anterior margin of pupil. Mental barbels approximately equal in length to maxillary barbel and to each other. Medial mentalbarbel origin located along vertical through rictus. Lateral mental-barbel origin situated posterior of vertical slightly short of middle of adpressed medial-mental barbel. Tips of adpressed lateral mental barbels nearly reaching posterior margin of opercle.

Dorsal fin moderately large overall with length of dorsal-fin base approximately 0.33 of HL. Dorsal fin damaged and relative proportions of longest ray cannot be determined. Dorsal-fin 


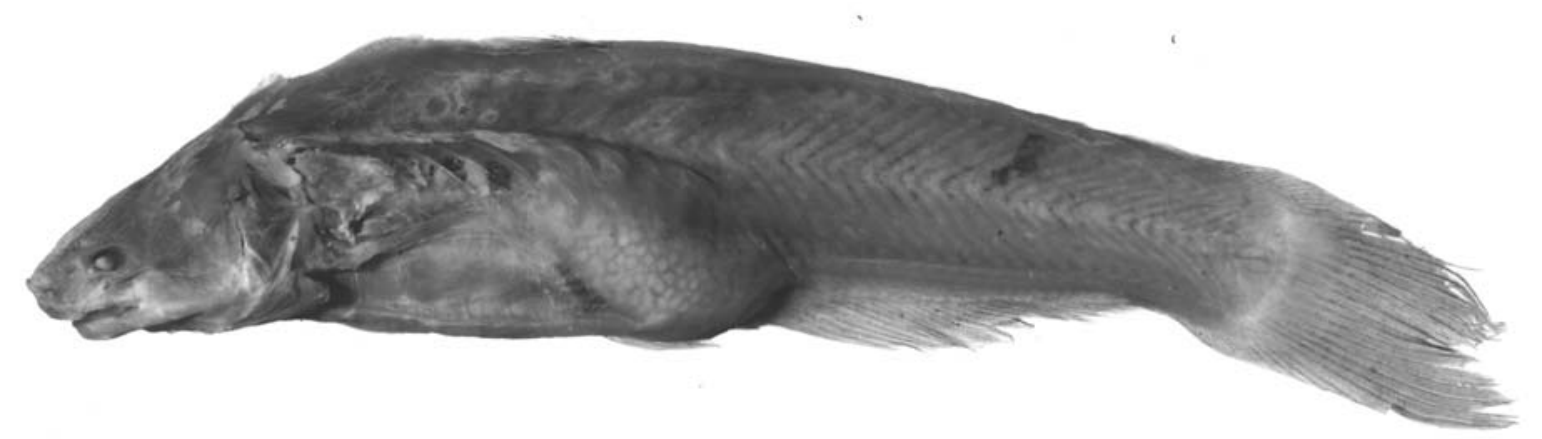

Fig. 23. Cetopsis jurubidae, holotype of Pseudocetopsis jurubidae, ANSP 71430, mature female, approximately 90 mm SL; Colombia, Chocó, río Jurubidá, Nuquí $\left(5^{\circ} 42^{`} \mathrm{~N}, 77^{\circ} 17^{`} \mathrm{~W}\right)$.

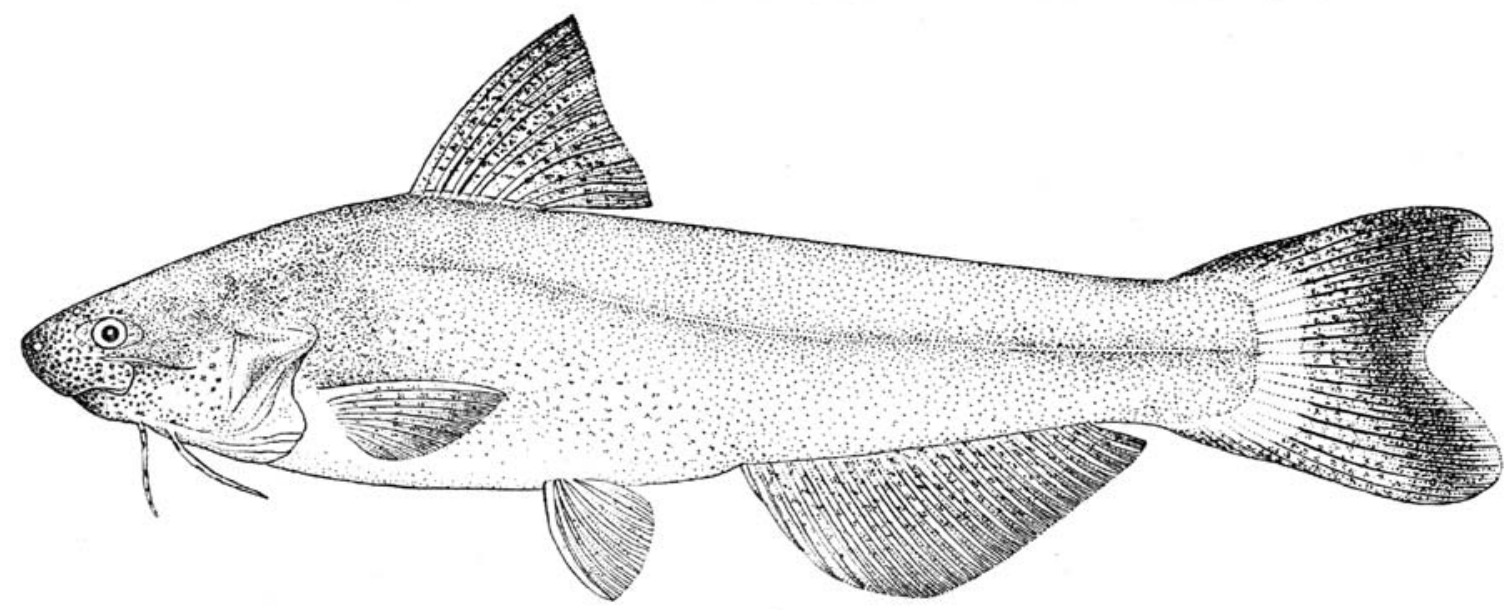

Fig. 24. Cetopsis jurubidae, holotype of Pseudocetopsis jurubidae, ANSP 71430; Colombia, Chocó, río Jurubidá, Nuquí ( $\left.5^{\circ} 42^{\prime} \mathrm{N}, 77^{\circ} 17^{\prime} \mathrm{W}\right)$; as illustrated by Fowler (1944, fig. 8).

spinelet apparently absent. First dorsal-fin ray missing. Form of distal margin of dorsal fin indeterminate as consequence of condition of specimen but shown as nearly straight by Fowler (see Fig. 24). Dorsal-fin origin located at approximately anterior 0.30 of SL and along vertical extending through distal one-half of adpressed pectoral fin. Position of tip of adpressed dorsal fin cannot be determined because of poor condition of specimen. Posterior most dorsal-fin ray without posterior, membranous attachment to body. No filaments illustrated for first ray of dorsal fin by Fowler (1944; see Fig. 24).

Caudal fin shallowly-forked, apparently symmetrical (see also Fowler, 1944, fig. 8); tips of lobes slightly rounded. Length of longest caudal-fin ray approximately 1.5 times length of middle fin rays.

Base of anal fin comparatively long, but length as proportion of SL cannot be determined because of condition of holotype. Anal-fin origin located well posterior of middle of SL, and slightly anterior to vertical through middle of TL. Analfin margin relatively straight, but exact form indeterminate as consequence of poor condition of holotype, but shown as convex anteriorly and straight along rest of its length by Fowler (1944, fig. 8). Posterior most unbranched anal-fin ray longest in fin, with subsequent rays becoming gradually shorter. Pos- terior most anal-fin ray without posterior, membranous attachment to body.

Pelvic fin moderately long; distal margin apparently nearly straight, with first ray longest. Pelvic-fin insertion apparently located anterior to middle of SL and posterior of vertical through posterior terminus of base of dorsal fin (Fig. 24). Tip of adpressed pelvic fin extending beyond middle of SL and to beyond anterior limit of vent but falling short of anal-fin origin. Medial most pelvic-fin ray with membranous attachment to body along basal two-thirds of its length.

Pectoral-fin length approximately two-thirds of HL. Pectoral-fin margin very gently convex, with first ray longest. First pectoral-fin ray not spinous and without distal filament (see also Fig. 24).

Coloration in alcohol. Coloration on head and body cannot be determined as a consequence of desiccation of the holotype, the only known specimen. Although the pigmentation was not discussed in detail in the original description of Cetopsis jurubidae, the illustration of the holotype by Fowler (1944, fig. 8) showed dark pigmentation scattered on head and body with larger spots of pigmentation on snout, upper jaw, region ventral to orbit, and on lower portion of opercle. 


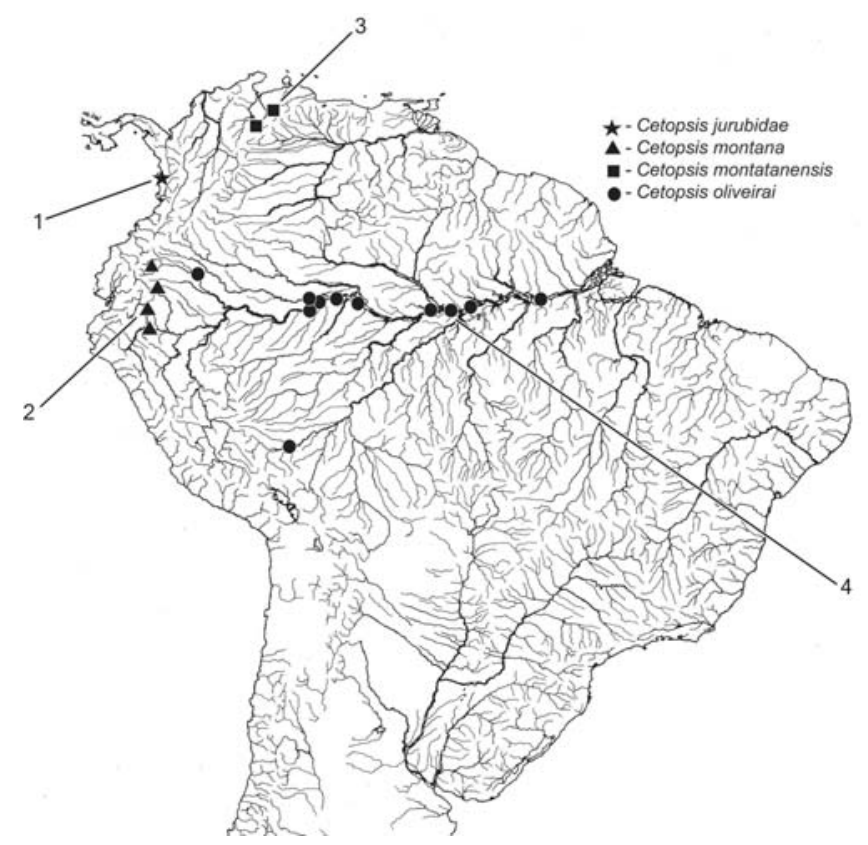

Fig. 25. Map of central and northern South America showing geographic distribution of Cetopsis jurubidae (1 = holotype locality of Pseudocetopsis jurubidae), Cetopsis montana ( $2=$ holotype locality), Cetopsis motatanensis ( 3 = holotype locality of Pseudocetopsis plumbeus motatanensis), and Cetopsis oliveirai (4 = holotype locality of Bathycetopsis oliveirai) (some symbols represent more that one locality and/or lot of specimens).

Dorsal and anal fins shown with scattered, dark pigmentation. Caudal fin with band of dark pigmentation on distal onehalf but with fin margin less intensely pigmented and with dark band wider on dorsal lobe.

Sexual dimorphism. It is impossible to determine whether this species demonstrates the sexually-dimorphic features of the anal, pectoral, and dorsal fins because the species is known only from the holotype. The holotype is a mature female as evidenced by the well-developed eggs that are apparent through the desiccated body wall.

Distribution. Cetopsis jurubidae is only known from the río Jurubidá of the Pacific Ocean versant of western Colombia (Fig. 25).

Remarks. The holotype and only known specimen of Cetopsis jurubidae is in poor condition, apparently having been largely desiccated at some point. Although no other samples of the Cetopsinae from the río Jurubidá are available, the holotype is considered to represent a distinct species as evidenced by the features discussed in the "Diagnosis" above.

Material examined. 1 specimen (approximately $90 \mathrm{~mm} \mathrm{SL}$ ). Colombia. Choco: río Jurubidá, Nuquí ( $\left.5^{\circ} 42^{\prime} \mathrm{N}, 77^{\circ} 17^{\prime} \mathrm{W}\right)$, ANSP 71430, 1 (approximately $90 \mathrm{~mm} \mathrm{SL}$; exact length cannot be determined because of desiccation of specimen; holotype of Pseudocetopsis jurubidae).

\section{Cetopsis montana, new species}

Figs. 25, 26, Tables 9-15

Diagnosis. Cetopsis montana can be distinguished from all of its congeners by the combination of the presence of an eye, the conical teeth on the vomer and dentary, the rounded posterior nares that is distinctly separated from the contralateral nares by a distance greater than the width of the posterior nares, the absence of a dark humeral spot, the presence of a posteriorly-rounded, variably-developed, bilobed patch of dark pigmentation at the base of the caudal fin, the absence of a spot of dark pigmentation on the base of the dorsal fin and absence of prominent dark pigmentation along the membrane behind the first ray of the dorsal fin, the presence of approximately eye-size, dark spots on the lateral surface of the body, the absence of finely scattered, dark pigmentation across the lateral and anterior surfaces of the snout and the lateral surface of the body, and the possession of 19 to 21 branched anal-fin rays.

Description. Body moderately stout, slightly laterally compressed anteriorly and becoming progressively distinctlycompressed posteriorly. Body depth at dorsal-fin origin approximately $0.26-0.28$ of SL and approximately equal to HL. Lateral line on body complete, unbranched, and midlateral; extending from vertical through pectoral-fin base posteriorly to, and slightly upturned on, hypural plate and terminating prior to posterior margin of hypural plate. Dorsal profile of body slightly convex from nape to dorsal-fin origin and straight from dorsal-fin origin to caudal-fin base. Ventral profile of body convex along abdomen, approximately straight, but posterodorsally-slanted, along base of anal fin. Caudal-peduncle depth slightly greater than caudal-peduncle length.

Head in profile acutely triangular overall with bluntlyrounded snout. Dorsal profile of head slightly convex from tip of snout to nape. Ventral profile of head slightly convex. Margin of snout in dorsal view bluntly triangular. Postorbital margins of head running nearly in parallel from dorsal view. Enlarged jaw musculature slightly evident externally on dorsal surface of postorbital portion of head.

Opercular membrane attaching to isthmus only anterior of vertical through pectoral-fin insertion. Opercular opening moderate; extending ventral of pectoral-fin insertion by distance equal to snout length and extending dorsal of pectoral-fin insertion by distance slightly less than snout length.

Eye situated on lateral surface of head; located entirely dorsal to horizontal extending through pectoral-fin insertion; eye visible in dorsal view, but not in ventral view, of head. Middle of orbit located at approximately anterior one-fourth of HL. Eye diameter approximately one-half of snout length. Interorbital width approximately equal to distance from tip of snout to middle of eye. Anterior narial opening circular, surrounded by short, anteriorly-directed, tubular rim of skin. 


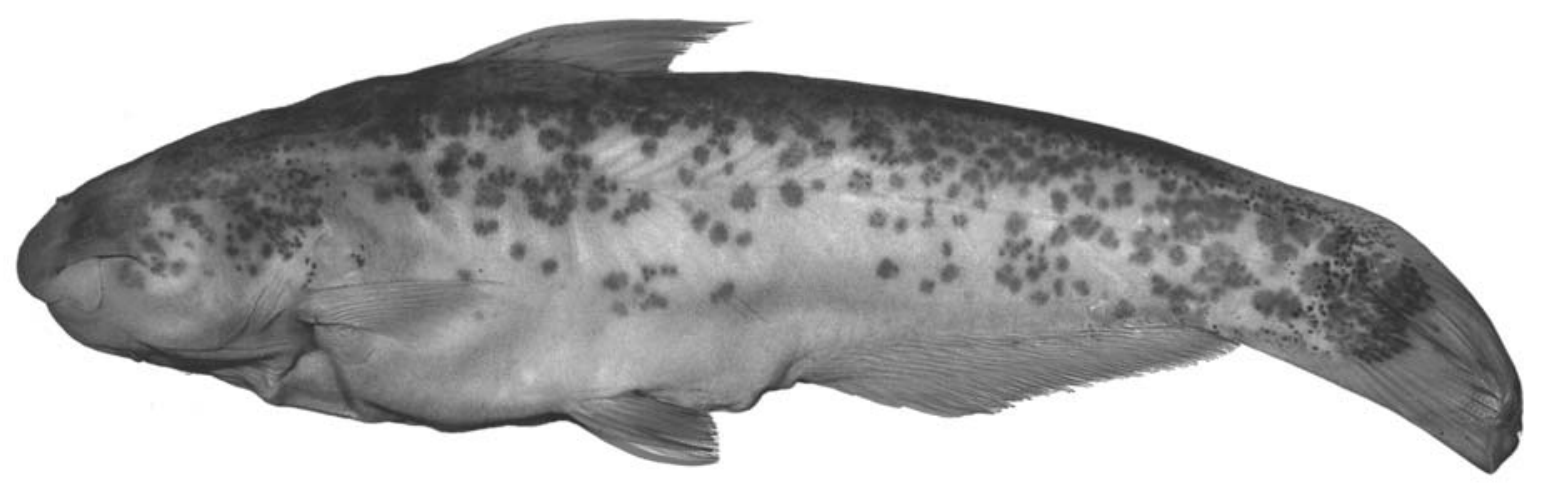

Fig. 26. Cetopsis montana, new species, holotype, LACM 41989-1, 108 mm SL; Peru, Amazonas, 100 m upriver from Caterpiza (latter locality at $3^{\circ} 55^{\prime} \mathrm{S}, 77^{\circ} 42^{\prime} \mathrm{W}$ ).

Opening of anterior nares located along horizontal extending through both tip of snout and maxillary-barbel origin. Distance between anterior nares approximately equal to snout length. Posterior narial opening located on dorsal surface of head, situated along vertical through anterior margin of orbit; opening nearly round, with anterior two-thirds of aperture surrounded by flap of skin with anterior portion of flap highest.

Mouth inferior; its width approximately one-half of HL. Margin of lower jaw gently rounded, its posterior limit reaching to vertical through posterior margin of orbit. Premaxillary tooth patch in form of gently-arched band, continuous across midline and with anterior margin convex and posterior margin concave and running in parallel to anterior margin. Teeth on premaxilla small, conical, and sharply-pointed and arranged in three or four, irregular rows. Teeth of inner most row of premaxillary dentition slightly larger than teeth in other rows. Vomerine teeth arranged in single, irregular row continuous across midline. Vomerine teeth stout, conical, and much larger than teeth on premaxilla or dentary. Dentary teeth comparable in shape to, but larger than, all but largest premaxillary teeth; with three, irregular tooth rows medially that taper to one row laterally.

Maxillary barbel slender, its length greater than distance from tip of snout to posterior of orbit, but less than one-half of HL; barbel origin located ventral to middle of orbit. Mental barbels approximately equal in length to each other but shorter than maxillary barbel. Medial mental-barbel origin located along vertical through rictus. Lateral mental-barbel origin situated slightly posterior of vertical through medial mental-barbel origin. Tips of adpressed mental barbels falling just short of posterior margin of opercle.

Dorsal fin moderately large overall with length of dorsalfin base approximately $0.40-0.42$ of HL. Longest branched dorsal-fin ray, excluding distal filament on first ray, equal in length to two-thirds of HL. Dorsal-fin spinelet absent. First dorsal-fin ray not spinous but with distal filament present in both sexes, filament proportionally longer in mature males. Distal margin of dorsal fin concave, with first ray longest. Dorsal-fin origin located at approximately anterior 0.34-0.35 of SL and along vertical extending through distal one-fourth of adpressed pectoral fin. Tip of adpressed dorsal fin reaching nearly to vertical through vent. Posterior most dorsal-fin ray without posterior, membranous attachment to body.

Caudal fin deeply-forked, symmetrical; tips of lobes pointed. Length of longest caudal-fin ray approximately two times length of middle fin rays.

Base of anal fin moderately long. Anal-fin origin located well posterior of middle of SL, and slightly anterior of vertical through middle of TL. Anal-fin margin straight in females and immature males, with posterior most unbranched anal-fin ray longest in fin and subsequent rays becoming gradually shorter. Anal-fin margin slightly convex in mature males. Posterior most anal-fin ray without posterior, membranous attachment to body.

Pelvic fin moderate; distal margin nearly straight, with first ray longest. Pelvic-fin insertion located anterior to middle of SL and along vertical through posterior terminus of base of dorsal fin. Tip of adpressed pelvic fin extending beyond middle of SL and falling far short of anterior limit of vent. Medial most pelvic-fin ray with membranous attachment to body along basal two-thirds of its length.

Pectoral-fin length, excluding distal filament, equal to approximately two-thirds of HL. Pectoral-fin margin sinusoidal, concave laterally and convex medially, with first ray longest and prolonged into distal filament, filament proportionally longer in mature males. First pectoral-fin ray not spinous.

Coloration in alcohol. Dark pigmentation covering dorsal portion of head from interorbital region to posterior of head. Dorsal portion of body dark. Lateral surface of body pale with scattered, approximately eye-size, dark spots. Spots more concentrated on dorsal and dorsolateral portions of body and on lateral surface of caudal peduncle. Ventral surface of head and body pale. Snout margin pale from posterior nares to tip of snout. Entire upper lip pale.

Dorsal fin pale other than for semicircular, basally-situated, dusky region and for dusky interradial membrane between first and second fin rays. Caudal fin with dark, bilobed spot extending from base of branched fin-rays posteriorly 
approximately to vertical through middle of length of innermost fin rays. Interradial membrane between posterior most unbranched and first branched rays of each lobe dusky in some darkly pigmented specimens. Remainder of caudal fin pale. Anal, pectoral, and pelvic fins pale.

All barbels dusky on basal one-half of anterior surface and otherwise pale.

Sexual dimorphism. The presumed mature males of Cetopsis montana have the filaments on the first rays of the dorsal and pectoral fins proportionally more elongate than are the extensions on those fins that occur in females and immature males. Mature males also have a slightly convex anal-fin margin rather than the straight margin to the fin that occurs in conspecific females and immature males. Both of the mature males of the species examined in this study are among the smallest available specimens of $C$. montana.

Distribution. Cetopsis montana occurs in the western portions of the Amazon basin in northeastern Peru and southeastern Ecuador (Fig. 25).

Etymology. The species name, montana, from the Latin for pertaining to mountains, refers to the piedmont regions of the eastern slopes of the Andean Cordilleras that are drained by the river systems inhabited by this species.

Remarks. We examined one lot of six small, very pale specimens (LACM 41741-2) that originated close to the location where the type series of Cetopsis montana was collected, but that lack the pigmentation pattern characteristic of $C$. montana. This population sample, nonetheless, agrees fully in meristic values and other features with the examined material of C. montana and is tentatively considered to be conspecific with that species.

One specimen from the rio Amazonas collected in the region above the mouth of the rio Madeira (INPA 8485) is apparently a member of the complex of species with the distinct, dark, bilobed patch at the base of the caudal fin that is characteristic of Cetopsis montana, C. pearsoni, and C. umbrosa. The overall dark pigmentation of the head and body of the specimen is, however, faded to such a degree as to render impossible a definitive identification of the specimen to species. Nonetheless, this record represents a major range extension eastward for the group of species that share this distinctive caudal-fin pigmentation pattern, and potentially represents yet another species of this complex. A resolution of that question must remain in abeyance until additional material with the characteristics of this assemblage of species from the central portions of the Amazon basin becomes available.

Material examined. 23 specimens (21-119 mm SL). Holotype. Peru. Amazonas: $100 \mathrm{~m}$ upriver from Caterpiza (approximately 355'S, 7742'W), M. P. Achamposh, 16 February 1980; LACM 41989-1, 1 (108). Paratypes. 11 specimens (45-119 mm SL). Peru. Amazonas: Caterpiza (approximately $3^{\circ} 55^{\prime}$ S, $77^{\circ} 42^{\prime} \mathrm{W}$ ), M. P.
Achamposh, 31 December 1979; LACM 41895-1, 1 (119).

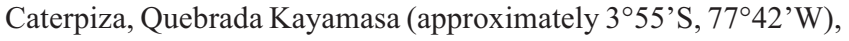
M. P. Achamposh, 11 December 1979; USNM 372759, 1 (88, formerly LACM 41873-1). Caterpiza (approximately $3^{\circ} 55^{\prime} \mathrm{S}$, $\left.77^{\circ} 42^{\prime} \mathrm{W}\right)$, M. P. Achamposh, 28 December 1979; LACM 418931, 1 (72). Río Santiago, La Poza (401'S, $77^{\circ} 45^{\prime}$ W), C. Swift et al., 20 January 1980; LACM 39887-3, 1 (45). 100 m upriver from Caterpiza (approximately $3^{\circ} 55^{\prime}$ 'S, $77^{\circ} 42^{\prime} \mathrm{W}$ ), C. Swift et al., 15 February 1980; LACM 39922-1, 1 (57). 200 m upriver from Caterpiza (approximately $3^{\circ} 55^{\prime}$ S, $77^{\circ} 42^{\prime}$ W), M. P. Achamposh, 6 February 1980; LACM 41945-2, 1 (107). Caterpiza (355'S, $\left.77^{\circ} 42^{\prime} \mathrm{W}\right)$, M. P. Achamposh, MUSM 20298, 2 (61-99, formerly LACM 42113-1). Loreto: río Napo, beach and backwater along right bank, just upstream from mouth of río Mazan, near town of Mazan $\left(03^{\circ} 29^{\prime} 10^{\prime \prime} \mathrm{S}, 7^{\circ} 06^{\prime} 24^{\prime \prime W}\right)$, M. H. Sabaj et al., 5 August 2001; ANSP 178173, 1 (60.4) Ecuador. Pastaza: Chunigrama in Chichirota ( $\left.2^{\circ} 23^{\prime} \mathrm{S}, 7^{\circ} 39^{\prime} \mathrm{W}\right)$, MEPN uncataloged, 1 (86.5), collected February 1954. Napo: río Catapino, río Pucuno basin $\left(0^{\circ} 40^{\prime} \mathrm{S}\right.$, $77^{\circ} 19^{\prime}$ W), J. Olalla, November 1980; USNM 177224, 1 (75). Nontype specimens. 11 specimens $(6,21-54 \mathrm{~mm} \mathrm{SL})$. Peru. Amazonas: río Marañon, vicinity of Santa Maria de Nieva (43' 'S, $\left.77^{\circ} 54^{\prime} \mathrm{W}\right)$, LACM 41741-2, 6 (25-52). Río Marañon, in El Pongo, LACM 41736-1, 1 (47; specimen cleared and stained). Río Santiago, Pinglo, LACM 41735-1, 1 (21; specimen cleared and stained). Ecuador. Napo: río Payamino, $23.3 \mathrm{~km}$ upstream from mouth in río Napo, sandy beach on right bank, FMNH 111690, 1 (54). Sucumbios: río Napo at Destacamento Tiputini, FMNH 111691, 2 (38-40).

\section{Cetopsis motatanensis (Schultz, 1944)}

Figs. 25, 27, 28, Tables 9-15

Pseudocetopsis plumbeus motatanensis Schultz, 1944: 255, pl.5, fig. b [type locality: Venezuela, río Motatán, $4 \mathrm{~km}$ above Motatán].-Ferraris \& Vari, 1992: 16 [holotype and paratype depository].-Mago-Leccia, 1970: 82 [Venezuela; common name].-Galvis et al., 1997: 75 [Colombia, Lago Maracaibo basin, río Catatumbo; life history notes; common name].--Evers \& Seidel, 2002: 741 [listing].

Hemicetopsis plumbeus motatanensis.-Burgess, 1989: 292 [Venezuela, Maracaibo basin, río Motatán].

Pseudocetopsis motatanensis.-Taphorn et al., 1997: 85 [Venezuela].-Vari \& Ferraris, 2003: 258 [in check list; distribution, common name].

Pseudocetopsis plumbeus.-Mojica-C., 1999: 565 [in part, citation of species from Colombia, río Catatumbo].

Diagnosis. Cetopsis motatanensis can be distinguished from all of its congeners by the combination of the presence of an eye, the conical teeth on the vomer and dentary, the rounded posterior nares that is distinctly separated from the contralateral nares by a distance greater than the width of the posterior nares, the absence of a dark humeral spot, the absence of a posteriorly-rounded, variably-developed, bilobed patch of dark pigmentation at the base of the caudal fin, the absence of dark pigmentation on the distal portions of the pelvic and anal fins, the caudal fin darkly pigmented throughout other than for the narrow pale distal margin, and the possession of 18 to 20 preanal vertebrae, 15 to 17 precaudal vertebrae, 33 to 


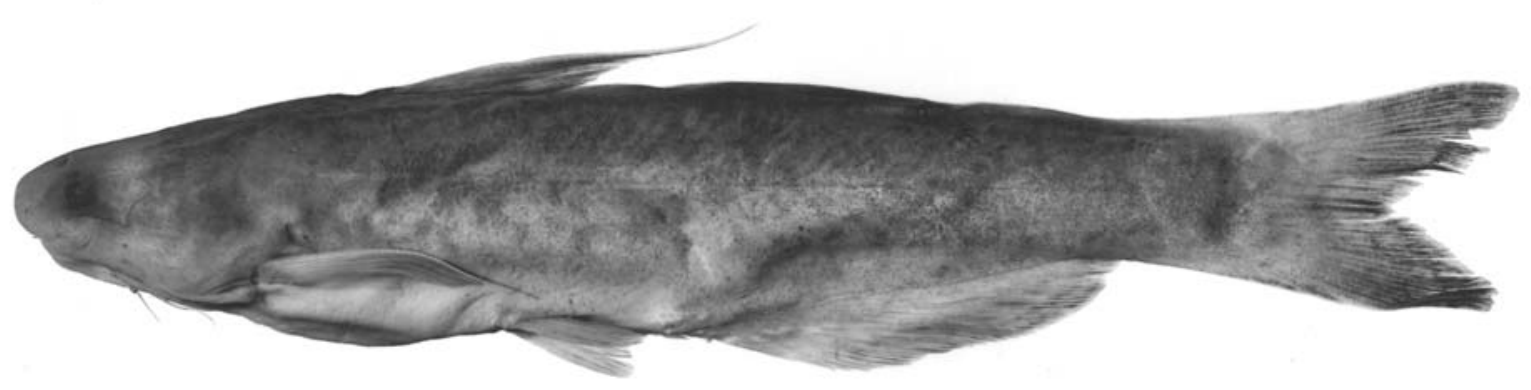

Fig. 27. Cetopsis motatanensis, paratype of Pseudocetopsis plumbeus motatanensis, male (right side, reversed), USNM 121268, 109 mm SL; Venezuela, Trujillo, río Motatán, 4 km below Motatán (approximately 9²4’N, 70³6’W).

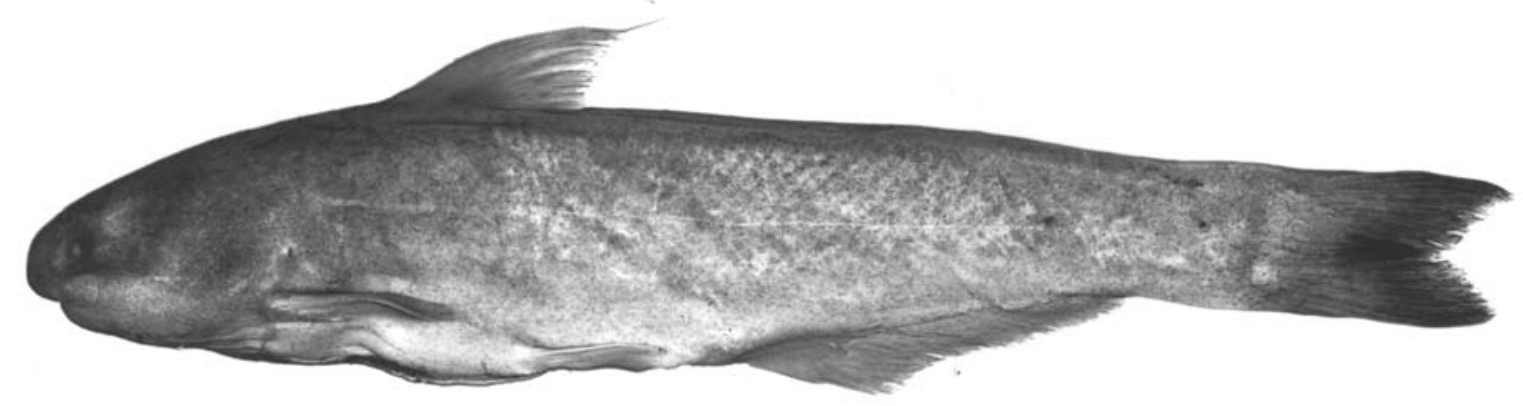

Fig. 28. Cetopsis motatanensis, paratype of Pseudocetopsis plumbeus motatanensis, female, USNM 121268, $155 \mathrm{~mm}$ SL; Venezuela, Trujillo, río Motatán, 4 km below Motatán (approximately 9²4’ N, $70^{\circ} 36^{\prime} \mathrm{W}$ ).

35 caudal vertebrae, 48 to 50 total vertebrae, and 9 pectoralfin rays.

Description. Body moderately-elongate, slightly-compressed anteriorly and becoming progressively distinctly-compressed posteriorly. Body depth at dorsal-fin origin approximately 0.22 0.23 of SL, and approximately equal to distance from anterior margin of orbit to posterior margin of opercle. Lateral line on body complete, unbranched, and midlateral; extending from vertical through pectoral-fin base onto hypural plate and either straight or very slightly dorsally-directed on hypural plate. Dorsal profile of body slightly convex from nape to dorsal-fin origin and straight from dorsal-fin origin to caudal-fin base. Ventral profile of body convex along abdomen, approximately straight, but posterodorsally-slanted, along base of anal fin. Caudal-peduncle depth slightly less than caudal-peduncle length.

Head in profile acutely triangular overall with bluntlyrounded snout. Dorsal profile of head nearly straight from tip of snout to nape. Ventral profile of head slightly convex. Margin of snout rounded in dorsal view. Postorbital margins of head running nearly in parallel from dorsal view. Enlarged jaw musculature slightly evident externally on dorsal surface of postorbital portion of head.

Opercular membrane attaching to isthmus only to region anterior to vertical through pectoral-fin insertion. Opercular opening moderate; extending ventral of pectoral-fin insertion by distance equal to distance from tip of snout to posterior margin of orbit and extending dorsal of pectoral-fin insertion by distance equal to snout length.
Eye situated on lateral surface of head; located entirely dorsal to horizontal extending through pectoral-fin insertion; eye visible in dorsal view, but not in ventral view, of head. Middle of orbit at approximately anterior one-fourth of HL. Eye diameter approximately equal to one-half of snout length. Interorbital width slightly greater than distance from tip of snout to posterior margin of orbit. Anterior narial opening circular, surrounded by short, anteriorly-directed, tubular rim of skin. Opening of anterior nares located along horizontal extending through both tip of snout and maxillary-barbel origin. Distance between anterior nares approximately equal to snout length. Posterior narial opening located on dorsal surface of head, situated along vertical through anterior margin of orbit; narial opening nearly round. Anterior two-thirds of posterior narial opening surrounded by flap of skin with anterior portion of flap highest.

Mouth inferior; its width approximately one-half of HL. Margin of lower jaw gently rounded, its posterior limit reaching to vertical through posterior margin of orbit. Premaxillary tooth patch in form of gently-arched band continuous across midline, with anterior margin convex and posterior margin concave and running in parallel to anterior margin. Teeth on premaxilla small, conical, and sharply-pointed, with teeth arranged in three regular rows across tooth patch. Vomerine teeth arranged in single irregular row continuous across midline. Vomerine teeth stout, conical, and much larger than teeth on both premaxilla or dentary. Dentary teeth comparable in shape to, but larger in size than, premaxillary teeth, with two rows in series medially that taper to one row laterally. 
Maxillary barbel slender, its length greater than distance from tip of snout to posterior of orbit, but less than one-half of HL; barbel origin located ventral to middle of orbit. Mental barbels approximately equal in length to each other, but shorter than maxillary barbel. Medial mental-barbel origin located along vertical through rictus. Lateral mental-barbel origin situated slightly posterior of vertical through middle of adpressed medial mental barbel. Tips of adpressed mental barbels falling far short of posterior margin of opercle.

Dorsal fin moderately large overall with length of dorsal-fin base approximately $0.48-0.52$ of HL. Longest branched dorsal-fin ray, excluding distal filament on first fin ray, equal in length to two-thirds of HL. Dorsal-fin spinelet absent. First dorsal-fin ray not spinous but with distal filament in both sexes; filament proportionally longer in mature males than in females and immature males (compare Figs. 27 and 28). Distal margin of dorsal fin straight, with first ray longest. Dorsal-fin origin located at approximately anterior $0.25-0.26$ of SL and along vertical extending through middle of adpressed pectoral fin. Tip of adpressed dorsal fin, excluding distal filament on first ray, reaching nearly to vertical through tip of adpressed pelvic fin. Posterior most dorsal-fin ray without posterior, membranous attachment to body.

Caudal fin moderately-forked, symmetrical; tips of lobes bluntly pointed. Length of longest caudal-fin ray approximately one and three-fourths times length of middle fin rays.

Base of anal fin moderately long. Anal-fin origin located well posterior of middle of SL, and slightly anterior of vertical through middle of TL. Anal-fin margin straight in females (Fig. 28 ) and immature males, with posterior most unbranched analfin ray longest and subsequent rays becoming gradually shorter. Anal-fin margin very slightly convex in mature males (Fig. 27). Posterior most anal-fin ray without posterior, membranous attachment to body.

Pelvic fin moderate; distal margin nearly straight, with first fin ray longest. Pelvic-fin insertion located anterior to middle of SL and along vertical through posterior terminus of base of dorsal fin. Tip of adpressed pelvic fin extending beyond middle of SL but falling far short of anterior limit of vent. Medial most pelvic-fin ray with membranous attachment to body along basal two-thirds of its length.

Pectoral-fin length approximately two-thirds of HL. Pectoral-fin margin very slightly concave, with first ray longest. First pectoral-fin ray not spinous but prolonged into distal filament with filament proportionally longer in mature males (Fig. 27) than in conspecific females and immature males.

Coloration in alcohol. Head and body covered with dark pigmentation, darker dorsally. Dark pigmentation arranged in irregular blotches with few, distinct, eye-size, rounded, dark spots in some individuals. Ventral portions of head and abdomen pale.

Dorsal fin dusky throughout, with basal portions somewhat more heavily pigmented. Caudal fin darkly pigmented throughout, more so on posterior one-half, other than for narrow pale distal margin. Pectoral, pelvic, and anal fins with scattered, dusky pigmentation.

Barbels with scattered, dark pigmentation on basal onehalf of anterior margins and barbels otherwise pale.

Sexual dimorphism. The presumed males of Cetopsis motatanensis have the filaments on the first rays of the dorsal and pectoral fins proportionally more elongate than those present in females and immature males of the species (compare Figs. 17 and 28). Mature males of the species also have the anal-fin margin convex rather than straight as in the case in females and immature males.

Distribution. Cetopsis motatanensis is endemic to the rivers of the Lago Maracaibo basin of northwestern Venezuela and northeastern Colombia (Fig. 25).

Common Name. Colombia: "Ciego" (Galvis et al., 1997: 75); Venezuela: "Bagre ciego" (Mago-Leccia, 1970: 82).

Ecology. According to Schultz (1944: 256), Cetopsis motatanensis was captured "in swiftly flowing water among rubble to coarse gravel."

Remarks. In his original description of Pseudocetopsis plumbeus motatanensis, Schultz (1944: 255) did not delve into the basis for placing that nominal form as a subspecies of Pseudocetopsis plumbeus (Steindachner) (=Cetopsis plumbea of this study). No specimens of P. plumbeus plumbeus were cited as having been examined in Schultz' study (1944), and the information provided for that nominal subspecies in Schultz's key (1944: 253) to the Venezuelan members of the Cetopsinae was apparently derived from the previous literature. Cetopsis motatanensis differs from the other nominal species assigned by Schultz (1944: 255) to Pseudocetopsis plumbeus in numerous features, most notably in the pigmentation patterns of the caudal fin, and it is consequently considered herein to be a distinct species.

Material examined. 11 specimens (57.5-155 mm SL). Venezuela. Merida: río Chama in El Vigia Trujillo $\left(8^{\circ} 35^{\prime} 54^{\prime \prime} \mathrm{N}\right.$, 71³7’31"W), MCNG 32199, 1 (72). Trujillo: río Monay, Maracaibo basin $\left(9^{\circ} 34^{\prime} \mathrm{N}, 70^{\circ} 36^{\prime} \mathrm{W}\right)$, INHS 28812, 1 (113). Río Motatán, $4 \mathrm{~km}$ above Motatán ( $\left.9^{\circ} 24^{\prime} \mathrm{N}, 7^{\circ} 36^{\prime} \mathrm{W}\right)$, USNM 121265, 1 (142, holotype of Pseudocetopsis plumbeus motatanensis). Río San Juan, tributary of río Motatán, at bridge, USNM 121266, 1 (57.5, paratype of Pseudocetopsis plumbeus motatanensis). Río Motatán, $8 \mathrm{~km}$ below Motatán (approximately $\left.9^{\circ} 22^{\prime} \mathrm{N}, 70^{\circ} 34^{\prime} \mathrm{W}\right)$, USNM 121267, 2 (67-81, paratypes of Pseudocetopsis plumbeus motatanensis). Río Motatán, $4 \mathrm{~km}$ below Motatán (approximately 9²4'N, 70³6'W), USNM 121268, 2 (109-155, paratypes of Pseudocetopsis plumbeus motatanensis). Río Motatán, at bridge, $22 \mathrm{~km} \mathrm{~N}$ of Motatán (approximately $\left.9^{\circ} 26^{\prime} \mathrm{N}, 70^{\circ} 35^{\prime} \mathrm{W}\right)$, USNM 121269, 3 (59-83, paraty-pes of Pseudocetopsis plumbeus motatanensis, largest specimen a mature male, 1 specimen, $77 \mathrm{~mm}$, cleared and stained). 


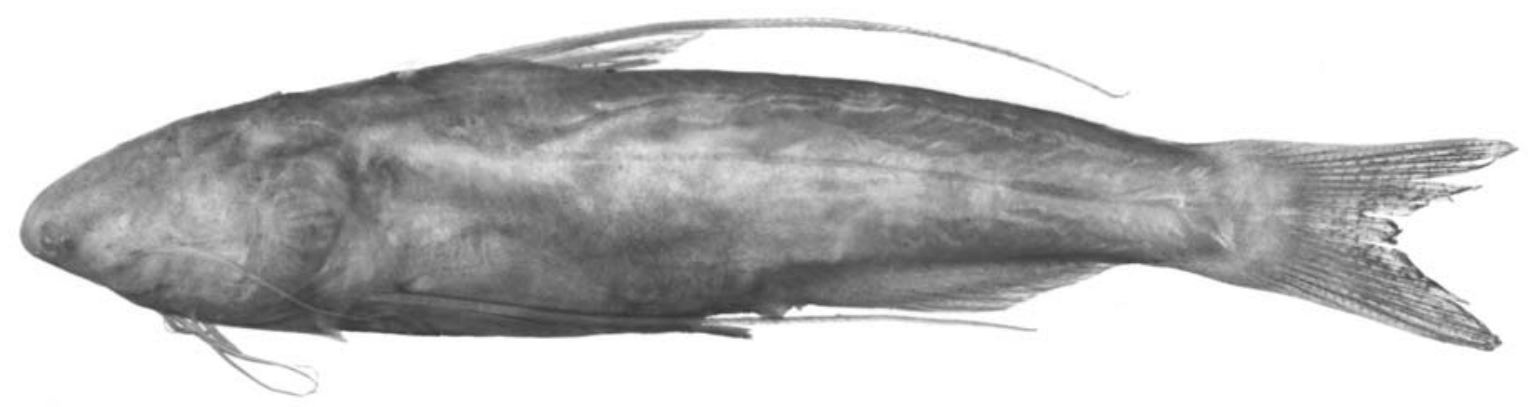

Fig. 29. Cetopsis oliveirai, MUSM 9033, 30.6 mm SL; Peru, Madre de Dios, Palma Real (12³6’S 6857’ W).

\section{Cetopsis oliveirai (Lundberg \& Rapp Py-Daniel, 1994)}

Figs. 25, 29, Tables 9-15

Bathycetopsis oliveirai Lundberg \& Rapp Py-Daniel, 1994: 383, fig. 3 [type locality: Brazil, Amazonas State, rio Solimões north of Ilha da Marchantaria, approximately 15 $\mathrm{km}$ upstream of the mouth of rio Negro at Manaus, $3^{\circ} 15^{\prime} \mathrm{S}$, 600’ W].-de Pinna \& Vari, 1995: 9 [phylogenetic position].-Evers \& Seidel, 2002: 741 [listing].-Vari \& Ferraris, 2003: 257 [in check list; distribution].

Diagnosis. Cetopsis oliveirai can be readily distinguished from all other members of the Cetopsinae by its complete absence of eyes (versus the presence of those organs to some degree in all other species of the Cetopsinae) and the presence of extremely-elongate distal filaments on the first ray of the dorsal fin (length of fin longer than one-half of the SL) and pectoral fin (filament extending posteriorly to beyond the vertical through the middle of the base of the anal fin). It is further distinguished among the species of Cetopsis by the number of total anal-fin rays (17 to 19 versus 22 or above in all congeners) and caudal vertebrae ( 25 or 26 versus 28 or above, respectively).

Description. Body relatively slender, somewhat compressed anteriorly, becoming increasingly compressed posteriorly. Body depth at dorsal-fin origin approximately $0.20-0.21$ of SL and approximately two-thirds of HL. Lateral line on body complete, unbranched, and midlateral; extending from vertical through pectoral-fin base onto hypural plate and terminating slightly prior to, or at, posterior margin of hypural plate. Dorsal profile of body variably slightly convex from nape to dorsal-fin origin; straight to slightly convex from dorsal-fin origin to caudal-fin base. Ventral profile of body nearly straight along abdomen, approximately straight or slightly concave, but posterodorsally slanted, along base of anal fin. Caudalpeduncle depth approximately equal to two-thirds of caudalpeduncle length.

Head triangular overall in profile and tapers to acute, rounded tip anteriorly. Dorsal profile of head convex from tip of snout to posterior of nape. Ventral profile of head slightly less convex than dorsal profile. Profile of snout in dorsal view converging to level of anterior nares, then incised between anterior nares and tip of snout, with anterior margin of snout rounded (see Lundberg and Rapp Py-Daniel, 1994, fig. 4). Lateral margins of portion of head posterior of posterior nares running approximately in parallel. Dorsal surface of posterior portion of head without externally-apparent, enlarged jaw musculature.

Opercular membrane attaching to isthmus as far posteriorly as vertical through pectoral-fin insertion. Opercular opening relatively restricted; extending approximately equal distances both dorsal and ventral of pectoral-fin insertion; overall length of aperture approximately equal to distance from tip of snout to symphysis of lower jaw.

Eye absent. Anterior narial opening circular, surrounded by short, anteriorly-directed tubular rim of skin. Opening of anterior nares located at horizontal extending through both tip of snout and maxillary-barbel origin. Distance between anterior nares approximately equal to one-half of distance from anterior to posterior nares. Posterior narial opening located on dorsal surface of head proximate to dorsal profile of head; opening ovoid, with long axis of aperture running in parallel to body axis. Distance between posterior nares approximately one-half distance between anterior nares. Anterior one-half of posterior narial opening bordered by low flap of skin.

Mouth inferior; its width approximately one-fourth to onethird of HL. Margin of lower jaw broadly rounded, its posterior limit falling just short of vertical through anterior margin of posterior nares. Premaxillary tooth patch elongate, continuous across premaxillae with anterior margin convex and posterior margin concave and running in parallel to anterior margin. Teeth on upper jaw small, conical, and sharplypointed; with teeth arrayed in two rows for most of length of premaxilla, but reduced to one row near symphysis. All premaxillary teeth of approximately same size. Vomerine teeth arranged in single, anteriorly-convex, continuous row. Vomerine teeth stout, conical, sharply-pointed, of uniform size throughout, and much larger than teeth in either jaw. Dentary with single row of conical, pointed teeth along much of dentigerous surface and with shorter second tooth row located anterior to primary tooth row in region proximate to symphysis. Primary row of teeth of uniform size throughout and slightly shorter than, but distinctly less stout than, those on vomer. Teeth of anterior dentary tooth row slightly smaller than those in primary tooth row. 
Maxillary barbel slender, its length slightly greater than HL; barbel origin located at horizontal extending through anterior nares and midway between verticals through anterior and posterior nares. Length of mental barbels approximately two-thirds of HL. Medial mental-barbel origin located slightly anterior to vertical through posterior nares. Lateral mental-barbel origin situated along vertical through posterior margin of posterior nares. Tips of adpressed mental barbels extending past pectoral-fin insertion.

Dorsal fin with first ray distinctly elongate, its length greater than 0.50 of SL. No sexual dimorphism apparent in length of first dorsal-fin ray. Length of base of dorsal fin slightly less than one-half of HL, its length approximately equal to distance between anterior and posterior nares. Dorsal-fin spinelet absent. First dorsal-fin ray not spinous. Distal margin of dorsal fin nearly straight from second to sixth rays and convex from sixth to posterior most fin ray. Dorsal-fin origin located at approximately anterior one-third of SL, and along vertical through distal one-third of adpressed pectoral fin excluding distal filament on first ray. Posterior most dorsal-fin ray without posterior, membranous attachment to body.

Caudal fin moderately-forked, symmetrical or nearly symmetrical; tips of lobes in form of rounded point. Length of longest caudal-fin ray slightly less that two times length of middle fin rays.

Base of anal fin comparatively short, approximately onefifth of SL. Anal-fin origin located slightly posterior of middle of TL. Anal-fin margin nearly straight. Posterior most unbranched anal-fin ray longest, with length of subsequent rays becoming gradually shorter. Posterior most anal-fin ray without posterior, membranous attachment to body.

Pelvic fin short; distal margin nearly straight with first ray longest. Pelvic-fin insertion located approximately at middle of SL and entirely posterior to vertical through posterior terminus of base of dorsal fin. Tip of adpressed pelvic fin falling short of vertical through vent. Medial most pelvic-fin ray with membranous attachment to body for basal two-thirds of its length.

Pectoral fin with long, filamentous, non-spinous first ray, with tip of ray extending to beyond vertical through middle of base of anal fin. No sexual dimorphism apparent in degree of development of filament. Pectoral-fin margin straight and obliquely-angled medial to filamentous ray.

Coloration in alcohol. Few, small, scattered, dark chromatophores present in some specimens on occipital region of head and on either side of dorsal midline of body in region from nape to vertical through posterior portion of base of anal fin. Rest of head, body, and fins without dark pigmentation. Remaining examined specimens lacking any dark pigmentation on head, body, fins, and barbels.

Coloration in life. Based on photograph of recently captured specimen from southeastern Peru provided by M. Goulding. Overall coloration of head and body pink. Midlateral surface of caudal peduncle and lateral, but not dorsolateral, surface of body bright silver. No dark pigmentation apparent on head, body, or fins.

Sexual dimorphism. Cetopsis oliveirai does not demonstrate the sexual dimorphism in the degree of development of the dramatically-developed filaments on the dorsal and pectoral fins and in the form of the margin of anal-fin that is present in many other species of the Cetopsinae.

Ecology. All examined specimens of Cetopsis oliveirai were captured using trawl-nets in the main channels of large rivers in the Amazon basin. Lundberg \& Rapp Py-Daniel (1994) reported that all of their specimens of the species originated in white water systems at depths of 2 to $40 \mathrm{~m}$ and that the species feeds on terrestrial arthropods. Peruvian samples were captured at depth of approximately $20 \mathrm{~m}$ in the middle of the main river channel (F. Chang, MUSM; pers. commun., 1996).

Distribution. Cetopsis oliveirai is known from the middle and upper portions of the Amazon basin in Brazil and Peru (Fig. 25). Given that $C$. oliveirai inhabits a difficult to sample habitat, the middle and bottom portions of the water column of main river channels, it is likely that the actual geographic distribution of the species is distinctly greater than is indicated by the available population samples.

Material examined. 46 specimens (40, 15-36 mm SL). Brazil. Amazonas: rio Solimões, $5.4 \mathrm{~km}$ below Paraná de Javarimim, MZUSP 79338, 2 (30.5-32.0; 1 specimen, $33 \mathrm{~mm}$, cleared and stained). Rio Solimões, 17.8 km below Lago Amori, MZUSP 79337, 3 (23-28; 1 specimen, $28 \mathrm{~mm}$, cleared and stained). Rio Solimões, near Ilha de Marchantaria and Ilha Baixo, approximately 10 to $20 \mathrm{~km}$ above rio Negro (approximately $3^{\circ} 10^{\prime} \mathrm{S}, 59^{\circ} 44^{\prime} \mathrm{W}$ ), MZUSP 44068, 1 (27, paratype of Bathycetopsis oliveirai). Rio Solimões, near Ilha de Marchantaria and Ilha Baixo, approximately $10 \mathrm{~km}$ above rio Negro (approximately $\left.3^{\circ} 10^{\prime} \mathrm{S}, 59^{\circ} 44^{\prime} \mathrm{W}\right)$, DU F1170, 1 (30). Rio Solimões, $13 \mathrm{~km}$ downstream of São Antonio do Iça (approximately $3^{\circ} 05^{\prime} \mathrm{S}$, $\left.67^{\circ} 57^{\prime} \mathrm{W}\right)$, USNM 352353, 3 (26-29). Rio Solimões (approximately $\left.3^{\circ} 18^{\prime} 24^{\prime \prime S}, 67^{\circ} 57^{\prime} 17^{\prime \prime W}\right)$, USNM 371875, 5 (15-33). Rio Solimões (approximately $3^{\circ} 20^{\prime} 29.2^{\prime \prime S}, 67^{\circ} 59^{\prime} 26^{\prime \prime W}$ ), USNM 371876, 1 (32). Rio Solimões, $1.9 \mathrm{~km}$ from its mouth upriver to Japurá $\left(3^{\circ} 13^{\prime} 21^{\prime \prime S}\right.$, 6446'58"W), MZUSP 56430, 2 (29-30). Rio Solimões, 26.2 km above Paraná Porto Alegre ( $\left.{ }^{\circ} 40^{\prime} 49^{\prime \prime S}, 66^{\circ} 53^{\prime} 21^{\prime \prime W}\right)$, MZUSP 56428 , 3 (20-26). Rio Solimões, below Purus ( $\left.3^{\circ} 35^{\prime} 49^{\prime \prime S}, 61^{\circ} 20^{\prime} 56^{\prime \prime W}\right)$, MZUSP 57758, 1 (30). Rio Solimões, $50 \mathrm{~km}$ below Paraná do Jucaram (253'11"S, 65¹1'01"W), MZUSP 56299, 1 (29). Rio Solimões, 25 km below Paraná Amaturá ( $\left.3^{\circ} 10^{\prime} 48^{\prime \prime S}, 67^{\circ} 55^{\prime} 40^{\prime \prime W}\right)$, MZUSP 55683, 1 (29). Rio Içá, 13.9 km below paraná Pombas (306’55"S, 68ํํ'W), MZUSP 56429, 1 (21); MZUSP 79336, 1 (21). Rio Amazonas ( $\left.3^{\circ} 17^{\prime} 33^{\prime \prime S}, 58^{\circ} 54^{\prime} 13^{\prime \prime}\right)$, MZUSP 57762, 1 (29). Rio Amazonas, above mouth of rio Madeira (approximately $3^{\circ} 17^{\prime} 27^{\prime \prime} \mathrm{S}$, 58 56’33"W), USNM 371878, 1 (27.9). Rio Amazonas, above mouth of rio Madeira (approximately $3^{\circ} 16^{\prime} 28.7^{\prime \prime S}, 58^{\circ} 55^{\prime} 31^{\prime \prime W}$ ), USNM 371877, 1 (28.0). Para: rio Amazonas, 36.9 km below Tapajós (2²5’27"S, 54²4’30"W), MZUSP 55693, 1 (29). Peru. Loreto: río Aguarico, at Castana ( $\left.0^{\circ} 48^{\prime} \mathrm{S}, 75^{\circ} 14^{\prime} \mathrm{W}\right)$, MUSM 4849, 6 (33-36). Madre de Dios: Palma Real (12³6'S 6857’W), MUSM 9033, 10 (22-35). 


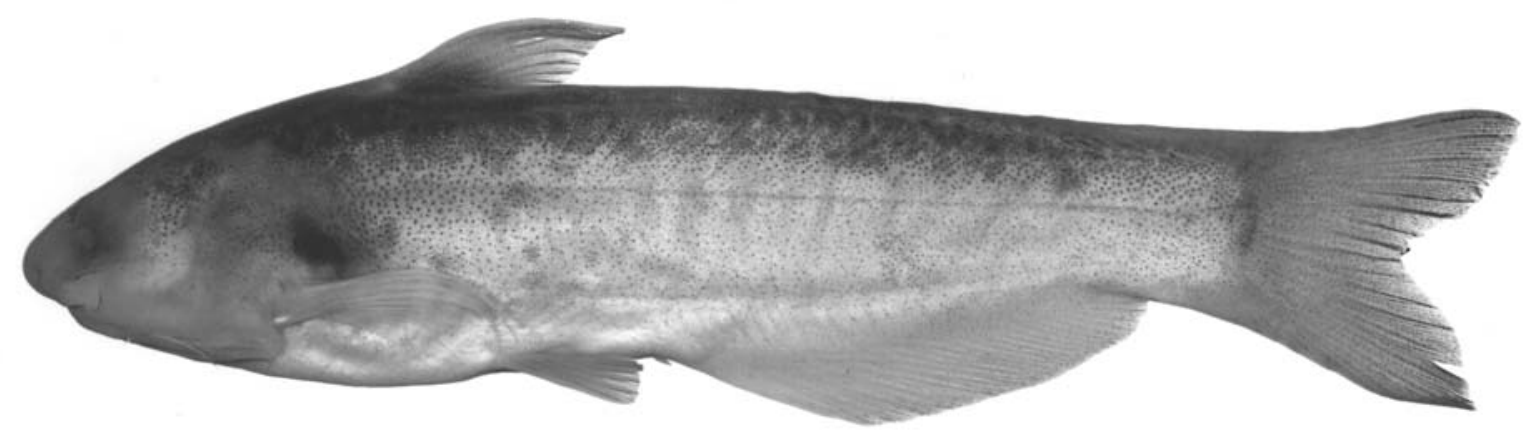

Fig. 30. Cetopsis orinoco, INHS 60121, 94 mm SL; Venezuela, Yaracuy, río Guarataro ( $\left.10^{\circ} 35^{`} \mathrm{~N}, 68^{\circ} 44^{`} \mathrm{~W}\right)$.

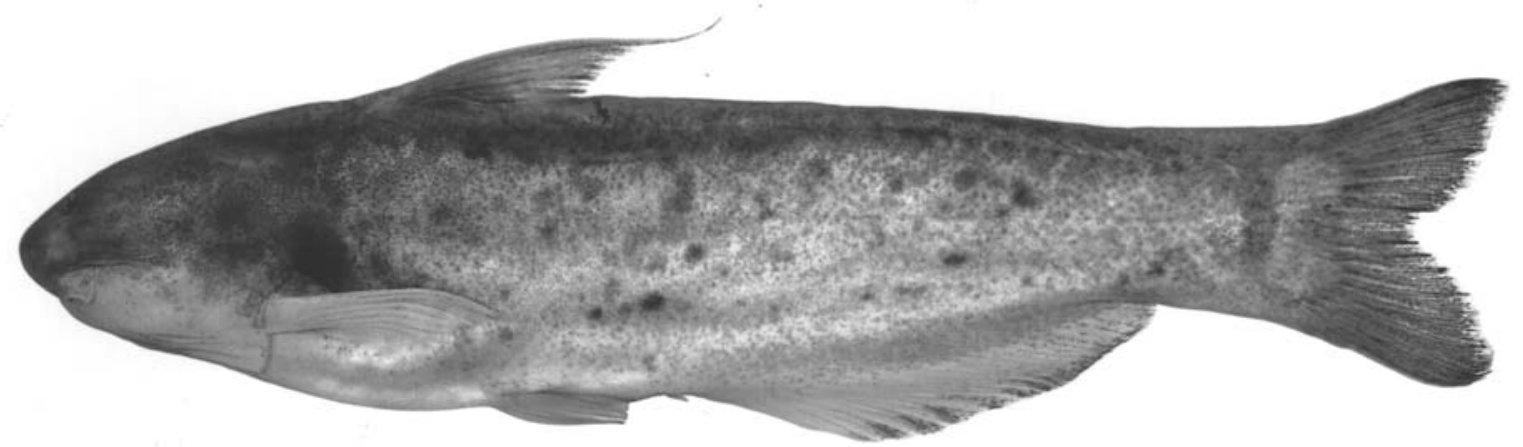

Fig. 31. Cetopsis orinoco, INHS 60096, mature male, 96 mm SL; Venezuela, Yaracuy, río Tupe ( $\left.10^{\circ} 31^{\prime} \mathrm{N}, 68^{\circ} 53^{\prime} \mathrm{W}\right)$.

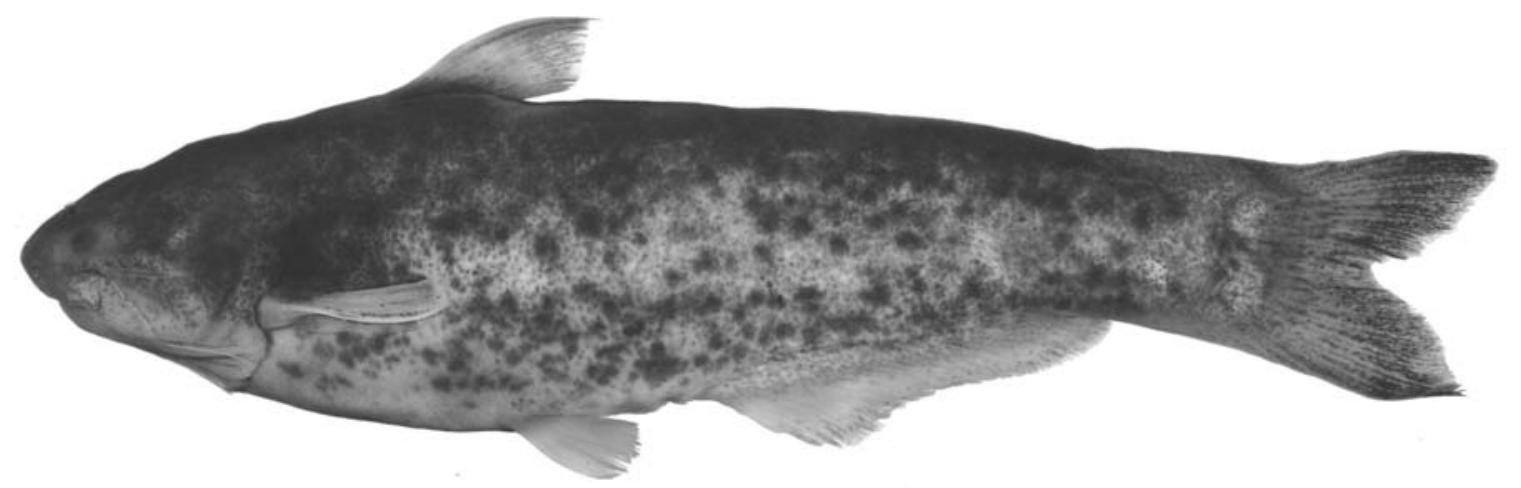

Fig. 32. Cetopsis orinoco, INHS 27880, $81.5 \mathrm{~mm}$ SL; Venezuela, Barinas, Caño Curito ( $\left.7^{\circ} 22^{`} \mathrm{~N}, 71^{\circ} 05^{`} \mathrm{~W}\right)$.

\section{Cetopsis orinoco (Schultz, 1944)}

Figs. 30-33, Tables 9-15

Pseudocetopsis plumbeus orinoco Schultz, 1944: 253, pl. 5, fig. a [type locality: río Torbes, $1 \mathrm{~km}$. above Táriba, Orinoco system, Venezuela].-Gosline, 1945: 54 [in listing of species in Cetopsidae].-Mago-Leccia, 1970: 82 [Venezuela; common name].-Fernández-Yépez, 1972b: 14, figs on pages 11 and 14 [Venezuela, río Yaracuy basin; habitat and common name].-Ferraris \& Vari, 1992: 16 [holotype and paratype depository].--Evers \& Seidel, 2002: 741 [listing].

Pseudocetopsis plumbeus [not of Steindachner, 1882].-Baskin et al., 1980: 184 [Venezuela, río Portuguesa basin, piedmont and high Llanos; feeding on terrestrial insects].Machado-Allison \& Moreno, 1993: 86 [Venezuela, río
Orituco basin].-Machado-Allison et al., 1993: 131 [Venezuela, Llanos].-Mojica-C., 1999: 565 [in part, citations of species from Colombia, río Orinoco, río Cusiana, río Meta, río Arauca].

Hemicetopsis plumbeus orinoco.-Burgess, 1989: 292 [literature compilation].

Pseudocetopsis orinoco.-Taphorn et al., 1997: 85 [Venezuela].-Vari \& Ferraris, 2003: 258 [in check list; distribution, common name].

Diagnosis. Cetopsis orinoco can be distinguished from all of its congeners by the combination of the presence of an eye, the conical teeth on the vomer and dentary, the rounded posterior nares that is distinctly separated from the contralateral nares by a distance greater than the width of the posterior 
nares, the presence of a dark humeral spot, the lack of a pattern of dark pigmentation on the pectoral and pelvic fins other than for a thin, clear margin, the presence of dark pigmentation on the caudal fin, particularly on the distal portions of the fin, and the possession of 30 to 35 caudal vertebrae, 43 to 46 total vertebrae, 23 to 30 total anal-fin rays, and 19 to 24 branched anal-fin rays.

Description. Body typically moderately-elongate although specimens with distended abdomens appear somewhat deeper bodied. Body slightly-compressed laterally anteriorly and becoming progressively distinctly-compressed posteriorly. Body depth at dorsal-fin origin approximately $0.25-0.27$ of SL and approximately equal to HL in specimens without distended abdomens. Specimens with distended abdomens with body depth approximately $0.32-0.34$ of SL and somewhat greater than HL. Lateral line on body complete, unbranched, and midlateral; extending from vertical through pectoral-fin base to hypural plate with short, dorsal bend on hypural plate. Dorsal profile of body slightly convex from nape to dorsal-fin origin and straight or nearly straight from dorsal-fin origin to caudal-fin base. Ventral profile of body convex along abdomen, more so in specimens with distended abdomens, approximately straight, but posterodorsally-slanted, along base of anal fin. Caudal-peduncle depth slightly greater than caudal-peduncle length.

Head in profile acutely triangular overall with bluntlyrounded snout. Dorsal profile of head gently convex from tip of snout to nape. Ventral profile of head slightly convex. Margin of snout in dorsal view rounded. Postorbital margins of head running nearly in parallel from dorsal view. Enlarged jaw musculature slightly evident externally on dorsal surface of postorbital portion of head. Canals and pores associated with laterosensory system on head apparent in some smaller and less intensely pigmented specimens, but canal system masked by pigmentation in larger, more darkly pigmented individuals.

Opercular membrane attaching to isthmus only to region anterior to vertical through pectoral-fin insertion. Opercular opening moderate; extending ventral of pectoral-fin insertion by distance equal to distance from tip of snout to posterior margin of orbit and extending dorsal of pectoral-fin insertion by distance equal to snout length.

Eye situated on lateral surface of head; located entirely dorsal to horizontal extending through pectoral-fin insertion; eye visible in dorsal view, but not in ventral view, of head. Middle of orbit located at approximately anterior one-fourth of HL. Eye diameter slightly less than one-half of snout length. Interorbital width slightly greater than distance from tip of snout to posterior margin of orbit. Anterior narial opening circular, surrounded by short, anteriorly-directed, tubular rim of skin. Opening of anterior nares located along horizontal extending through maxillary-barbel origin, but ventral of horizontal extending through tip of snout. Distance between anterior nares approximately equal to snout length. Posterior narial opening located on dorsal surface of head, situated along vertical through anterior margin of orbit; narial opening nearly round. Anterior two-thirds of posterior narial opening surrounded by flap of skin with anterior portion of flap highest.

Mouth inferior; its width approximately one-half of HL. Margin of lower jaw gently rounded, its posterior limit reaching to vertical through posterior margin of orbit. Premaxillary tooth patch in form of gently-arched band continuous across midline with anterior margin convex and posterior margin concave and running in parallel to anterior margin. Teeth on premaxilla small, conical, and sharply-pointed, with teeth arranged in three regular rows across entire tooth patch. Vomerine teeth arranged in single, irregular row continuous across midline. Vomerine teeth stout, conical, and much larger than teeth on premaxilla. Dentary teeth comparable in shape and size to vomerine teeth and much larger than premaxillary teeth; with two rows in series medially that taper to one row laterally.

Maxillary barbel slender, its length greater than distance from tip of snout to posterior of orbit, and approximately onethird of HL; barbel origin located ventral to anterior margin of orbit. Mental barbels approximately equal in length to each other, but shorter than maxillary barbel. Medial mental-barbel origin located slightly posterior to vertical through rictus. Lateral mental-barbel origin situated slightly anterior of vertical through middle of adpressed medial mental barbel. Tips of adpressed mental barbels falling far short of posterior margin of opercle.

Dorsal fin moderately large overall with length of dorsalfin base approximately 0.31-0.33 of HL. Longest branched dorsal-fin ray, excluding distal filament on first ray, equal in length to two-thirds to three-fourths of HL. Dorsal-fin spinelet absent. First dorsal-fin ray not spinous but with distal filament present in both sexes; filament barely developed in females and immature males and proportionally longer in mature males. Distal margin of dorsal fin straight, with first ray longest. Dorsal-fin origin located at approximately anterior 0.27-0.29 of SL and along vertical extending through middle of adpressed pectoral fin. Tip of adpressed dorsal fin, excluding distal filament on first ray, falling slightly short of vertical through tip of adpressed pelvic fin. Posterior most dorsal-fin ray without posterior, membranous attachment to body.

Caudal fin shallowly-forked, symmetrical; tips of lobes bluntly pointed. Length of longest caudal-fin ray approximately 1.5 times length of middle fin rays.

Base of anal fin moderately long. Anal-fin origin located well posterior of middle of SL, and slightly anterior of vertical through middle of TL. Anal-fin margin straight or slightly concave in females and immature males, with posterior most unbranched anal-fin ray longest and subsequent fin rays becoming gradually shorter. Anal-fin margin very slightly convex in mature males. Posterior most anal-fin ray without posterior, membranous attachment to body.

Pelvic fin moderate; distal margin nearly straight, with first branched ray longest. Pelvic-fin insertion located anterior to middle of SL and along vertical through posterior terminus of base of dorsal fin. Tip of adpressed pelvic fin ex- 
tending beyond middle of SL and reaching to, or falling slightly short of, anterior limit of vent. Medial most pelvic-fin ray with membranous attachment to body along basal two-thirds of its length.

Pectoral-fin length approximately two-thirds of HL. Pectoral-fin margin straight or slightly convex with first ray longest in females and very slightly concave laterally in males. First pectoral-fin ray not spinous, with first ray longest and prolonged into short filament in some females and into distinct filament in mature males.

Coloration in alcohol. Overall coloration of head and body rather variable (Figs. 30-32). Head uniformly darkly pigmented dorsally and often laterally, with darker pigmentation extending ventrally to horizontal running through origin of maxillary barbel in most specimens. Lateral surfaces of head ventral to that level unpigmented or only partially darkly pigmented, with distinct boundary between pigmented and unpigmented regions. Dark pigmentation extending somewhat more ventrally on posterior portion of head in darkly pigmented individuals (Fig. 32). Ventral surface of head unpigmented. Snout darkly pigmented to tip. Margin of upper lip pale. Body pigmentation variable within and among samples from different portions of species distributional range (Figs. 30-32). Body generally darker dorsally, becoming progressively paler ventrally. Ventrolateral and ventral surfaces of abdomen usually pale (Figs. 30-31), but sometimes with ventrolateral area irregularly pigmented in region above pectoral-fin insertion. Lateral surface of body in many specimens with dark pigmentation formed of very small chromatophores and larger spots that often coalesce into dark spots of various sizes and shapes (Figs. 31, 32). Resultant spots range from barely evident to prominent and cover large proportion of lateral surface of body (Fig. 32). Diffuse, dark, humeral spot present on lateral surface of body immediately posterodorsal to pectoral-fin insertion. Spot larger than size of eye and apparent to some degree in all specimens that retain dark pigmentation, but somewhat hidden by overall darker body coloration in some individuals (Fig. 32).

Dorsal fin with scattered, dark pigmentation distributed over entire surface except along first unbranched ray and distal margin of fin. Dorsal fin pigmentation distinctly more intense basally and forming dark basal spot. Caudal fin variably darkly pigmented throughout other than for narrow, pale, distal margin, and less heavily pigmented region at the base of each caudal-fin lobe; lightly pigmented areas on caudal fin more obvious in overall more darkly pigmented individuals (Figs. 31, 32). Pectoral fin with scattered, dark pigmentation basally and occasionally on dorsal surface of interradial membranes of lateral most fin rays. Pelvic fin pale or with some scattered, dark pigmentation basally. Anal fin with scattered, dark pigmentation basally; fin typically pale distally but with irregular dark pigmentation along margin of fin in at least one adult male (Fig. 31).

Barbels with scattered, dark pigmentation on basal portions and otherwise pale.

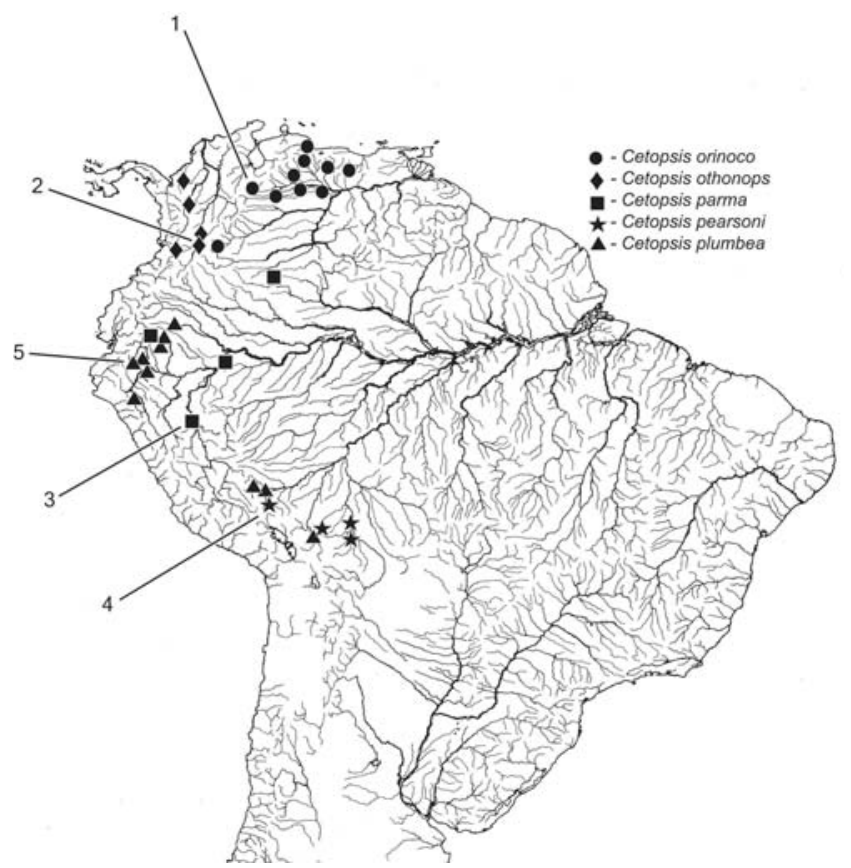

Fig. 33. Map of central and northern South America showing geographic distribution of Cetopsis orinoco $(1=$ holotype locality of Pseudocetopsis plumbeus orinoco), Cetopsis othonops ( 2 = holotype locality of Hemicetopsis othonops), Cetopsis parma ( 3 = holotype locality), Cetopsis pearsoni (4 $=$ holotype locality), and Cetopsis plumbea $(5=$ lectotype locality of Cetopsis plumbeus) (some symbols represent more that one locality and/or lot of specimens).

Sexual dimorphism. The presumed males of Cetopsis orinoco have the filaments on the first rays of the dorsal and pectoral fins proportionally more elongate than those occurring in females and immature males of the species. Mature males also have a convex margin to the anal fin rather than the straight margin of that fin found in females and immature males.

Distribution. Cetopsis orinoco occurs in the rivers of the eastern slope of the piedmont of the Cordillera Oriental and the southeastern slopes of the piedmont of the Cordillera of Merida in the río Orinoco basin of Colombia and Venezuela and in the río Aroa and río Yaracuy basins of the Caribbean Sea versant of northern Venezuela (Fig. 33).

Ecology. Schultz (1944: 255), evidently referring to the holotype, reported that the species was captured in "a mountain stream in very swiftly flowing water among gravel and rubble." Fernández-Yépez (1972b: 32) reported that the species (cited therein as Pseudocetopsis plumbeus orinoco) inhabits the middle portions of the water column of high-velocity streams during the night and hides among submerged branches and other obstructions in the river channel during the day. Many of the other lots of Cetopsis orinoco examined in this study also appear to have been captured in piedmont streams that 
presumably also have rapidly-flowing waters. Some of the examined population samples of the species originated, however, in the apparently more lentic river systems that are characteristic of the upper Llanos the río Orinoco basin.

Common Name. Venezuela: “BagreCiego”(Mago-Leccia, 1970: 82).

Remarks. In his original description of Pseudocetopsis plumbeus orinoco (=Cetopsis plumbea herein), Schultz (1944: 253) placed that nominal form as a subspecies of Pseudocetopsis plumbeus (Steindachner) without a discussion as to the basis for such an alignment of those taxa. Cetopsis orinoco differs from C. plumbea in various features, most obviously in the presence of a distinct dark spot on the lateral surface of the body above the basal portion of the pectoral fin in $C$. orinoco contrary to the absence of that pigmentation pattern in C. plumbea. As a consequence we recognize C. orinoco as a species distinct from C. plumbea.

All population samples herein considered to be Cetopsis orinoco posses the characteristic distinct dark spot on the lateral surface of the body above the basal portion of the pectoral fin. There is, however, an unusually large degree of variation in the form and distribution of the remaining components of the dark pigmentation on the body (see Figs. 3032) amongst and within those samples. We have, however, been unable to discern any pattern to that variation that would justify the recognition of more than one species within those population samples. Some specimens with distended abdomens are distinctly more deeply-bodied than is typical for the species giving these samples a much different overall appearance, but without any other known differences that would indicate that they represent anything other than gravid females or particularly well-fed specimens.

Cetopsis orinoco is unusual among fishes from northern South America that have been critically examined in recent decades in occurring in the río Orinoco basin as well as in the río Aroa and río Yaracuy systems, both of which are relatively small Caribbean Sea versant drainages in the states of Falcón and Yaracuy, Venezuela. The ichthyofauna of those two Caribbean slope rivers includes a series of endemic species (e.g., Creagrutus lepidus (Vari \& Harold, 2001: 134); Chaetostoma yurubiensis (Ceas \& Page, 1996: 671)). Despite a pattern of endemism in the fish fauna of the río Aroa and río Yaracuy basins, our examination of the samples of the Cetopsinae that originated in those two river systems failed to reveal any characteristics that would serve to delimit those populations from the samples of Cetopsis orinoco that were collected in the río Orinoco basin.

The majority of the samples of Cetopsis orinoco from the río Orinoco basin originated in the northwestern portions of that drainage system within Venezuela. The only exception to this generality involves three lots (NRM 27716, NRM 27721, ANSP 137558) that were collected in the upper reaches of the Colombian portion of the río Meta, a major western tributary of the río Orinoco. The río Meta samples fail to demonstrate any differences with respect to the Venezuelan material of the species despite the notable geographic separation of the localities from which these population samples originated. Few ichthyological samples are available from these intervening river systems and it likely that this apparent gap in the known distribution of Cetopsis orinoco is a function of the less than adequate sampling of the ichthyofauna in those river basins.

Material examined. 77 specimens (12-100.5 mm SL). Colombia. Meta: río Ocoa, of río Meta basin, $15 \mathrm{~km}$ E of Villavicencio $\left(4^{\circ} 08^{\prime} \mathrm{N}\right.$, $\left.75^{\circ} 15^{\prime} \mathrm{W}\right)$, NRM 27716, 1 (68). Río Guayuriba, of río Meta, at Villavicencio-Acacías crossing (35'N, 7350'W), NRM 27721, 3 (50-57). Río Metica, upstream from entrance of lago Mozambique, halfway to entrance to laguna $\left(03^{\circ} 56^{\prime} \mathrm{N}, 73^{\circ} 06^{\prime} \mathrm{W}\right)$, ANSP 137558 , 20 (24-42). Venezuela. Apure: $N$ of Puente Bruzual $\left(8^{\circ} 03^{\prime} \mathrm{N}\right.$, $\left.69^{\circ} 19^{\prime} \mathrm{W}\right)$, MCNG 3233, 4 (12-20). Aragua: río Guarico or tributary, between San Sebastian and San Casimiro, USNM 121264, 1 (91, paratype of Pseudocetopsis plumbeus orinoco). Barinas: Caño Curito $\left(7^{\circ} 22^{\prime} \mathrm{N}, 71^{\circ} 05^{\prime} \mathrm{W}\right)$, INHS 27880, 2 (81.5-82.0). Río Suripa tributary $\left(7^{\circ} 47^{\prime} \mathrm{N}, 69^{\circ} 53^{\prime} \mathrm{W}\right)$, INHS 28307,1 (30.5). Río Apure, below bridge at Bruzual ( $\left.8^{\circ} 03^{\prime} 30^{\prime \prime} \mathrm{N}, 6^{\circ} 19^{\prime} 40^{\prime \prime} \mathrm{W}\right), \mathrm{MCNG} 13521$,

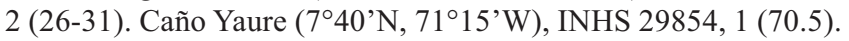
Caño Arenosa ( $\left.8^{\circ} 46^{\prime} \mathrm{N}, 70^{\circ} 15^{\prime} \mathrm{W}\right)$, INHS 31833, 1 (63.5). Río La Yuca $\left(8^{\circ} 44^{\prime} \mathrm{N}, 70^{\circ} 02^{\prime} \mathrm{W}\right)$, INHS 31856, 1 (84). Río Masparro (8`50’40"N, 7006’00"W), MCNG 5375, 6 (51-69). Río Mitiadoseco, USNM 194175, 5 (16-96.5). Río Las Palmas ( $8^{\circ} 07^{\prime} \mathrm{N}$, $\left.71^{\circ} 59^{\prime} \mathrm{W}\right)$, USNM 194180, 6 (35-67). Cojedes: río Orupe (9³3’ N, $\left.68^{\circ} 22^{\prime} \mathrm{W}\right)$, INHS 28948, 1 (50). Río San Carlos $\left(9^{\circ} 07^{\prime} \mathrm{N}, 68^{\circ} 25^{\prime} \mathrm{W}\right)$, INHS 32020, 1 (47). Falcón: río Aroa (1041’N, 68¹8'W), INHS 34945, 2 (37-83). Río Aroa between Palm Sola and Boca de Aroa (10³9'53"N, 68²2'15"W), MCNG 32099, 1 (47). Guarico: Tributary of río Paya of río Guarica, $23 \mathrm{~km} \mathrm{~S}$ of San Juan de los Morros on Federal Highway 2 (09³8’ N, 67²0’W), ANSP 137551, 3 (5577). Portuguesa: río Guanare, between Guanare and Bisucuy (9¹3'55"N, 6955'20"W), MCNG 10040, 3 (62-100.5). Río Boconó, in La Vegita (850’10"N, 6959’30"W), MCNG 5445, 1 (61). Río Tucupido, in Las Canoas, distinctly above dam, approximately $300 \mathrm{~m}$ elevation $\left(9^{\circ} 03^{\prime} 00^{\prime \prime} \mathrm{N}, 70^{\circ} 05^{\prime} 30^{\prime \prime} \mathrm{W}\right)$, MCNG 5654, 3 (60-84.5). Río Portuguesa, approximately $6 \mathrm{~km} \mathrm{~S}$ of La Quebrada, TNHC 13836, 1 (33.5). Río Tucupido in Las Canoas, above dam site, UF 33907, 2 (85-91). Tachira: río Camburito at Borde Seco dam, río Orinoco basin (7॰41’35"N, 71³2’25"W), MCNG 23118 , 2 (31-36). Zulia: río Torbes, $1 \mathrm{~km}$ above Tariba (7॰59' $\left.\mathrm{N}, 72^{\circ} 13^{\prime} \mathrm{W}\right)$, USNM 121263, 1 (92, holotype of Pseudocetopsis plumbeus orinoco). Yaracuy: río Tupe (10³1'N, 6853'W), INHS 60096, 2 (91- 96). Río Guarataro (10³5’N, 6844’W), INHS 60121, 1 (94).

\section{Cetopsis othonops (Eigenmann, 1912)}

Figs. 33, 34, Tables 9-15

Hemicetopsis othonops Eigenmann, 1912b: 17 [type locality: Colombia, Girardot].-1920a: 13 [Colombia, río Magdalena basin].-1920c: 29 [Colombia, upper río Magdalena, río Cauca].-1923: 56, pl. 3, fig. 1 [Colombia, río Magdalena basin; redescription based on Eigenmann, 1912b].-Fowler, 1942: 131 [Colombia, río Magdalena basin]; 1943: 245 [Colombia, río Magdalena].-Miles, 1943: 34 [Colombia, río Cauca; common name].-Dahl et al., 1963 [Colombia, río San Jorge; relative rarity].-Dahl, 1964: 41 [Colombia, río Sinú, Naín, and Tucurá; relative rarity]; 1971: 65, unnum- 


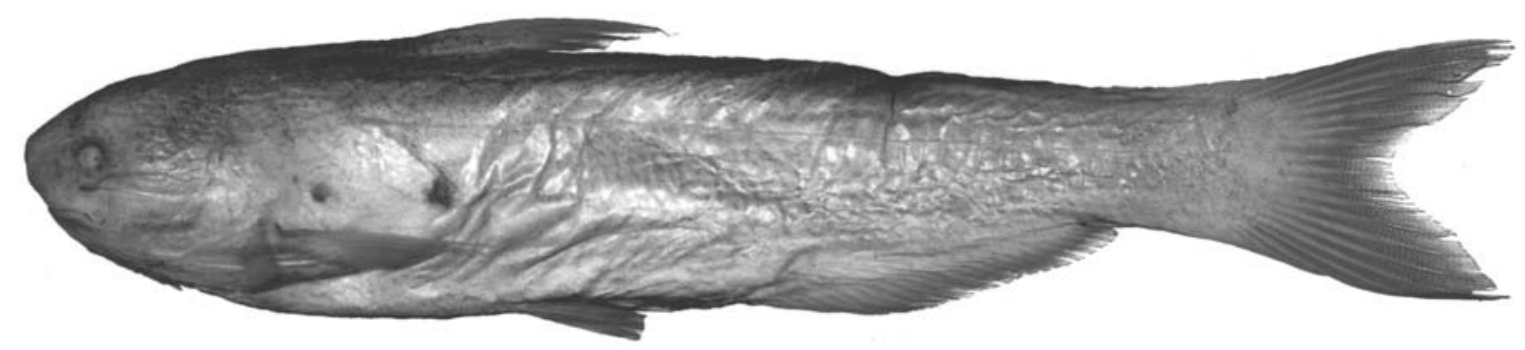

Fig. 34. Cetopsis othonops, paratype of Hemicetopsis othonops, USNM 167853, $85.7 \mathrm{~mm}$ SL; Colombia, Cundinamarca, Girardot $\left(4^{\circ} 18^{\prime} \mathrm{N}, 74^{\circ} 49^{\prime} \mathrm{W}\right)$ (dark spots on side of body are postmortem damage).

bered Fig. [Colombia; lower portions of río Magdalena, upper río Cauca, río Sinú; common name].-Miles, 1973: 31, fig. 8a [Colombia, río Magdalena; shifted from Pseudocetopsis to Hemicetopsis without comment].-Burgess, 1989: 292 [basins of río Magdalena and río Cauca].Ibarra \& Stewart, 1987: 44 [holotype and paratype despository].-Ferraris \& Vari, 1992: 16 [paratype depository].-Mojica-C., 1999: 565 [Colombia, río Magdalena, río Cauca, río San Jorge, río Sinú].

Pseudocetopsis othonops-Schultz, 1944: 253 [in key, assignment to Pseudocetopsis].-Miles, 1947: 86 [Colombia, río Magdalena, upper and lower río Cauca; common name].Evers \& Seidel, 2002: 741 [listing].-Vari \& Ferraris, 2003: 259 [in check list; distribution, common name].

Pseudocetopsis sp.-Cala, 1995: 49 [Colombia, río Magdalena basin, Betania Reservoir].

Diagnosis. Cetopsis othonops can be distinguished from all of its congeners by the combination of the presence of an eye, the conical teeth on the vomer and the dentary, the rounded posterior nares that is distinctly separated from the contralateral nares by a distance greater than the width of the posterior nares, the moderately wide mouth approximately equal to the distance from the tip of the snout to the posterior margin of the orbit and much less that one-half of HL, the unpigmented anterior and lateral margins of the snout, the absence of a dark humeral spot, the absence of a posteriorlyrounded, variably-developed, bilobed patch of dark pigmentation at the base of the caudal fin, the absence of a pattern of dark pigmentation on the distal portions of the pectoral and anal fins, the limitation of dark pigmentation to the basal portions of the middle rays of the dorsal fin and the absence of dark pigmentation on the remainder the fin or along the length of the first dorsal-fin ray, the absence of dark pigmentation across all of the caudal fin other than for a thin stripe along the margin, and the possession of 45 to 48 total vertebrae, 23 to 28 total anal-fin rays, and 13 to 15 precaudal vertebrae.

Description. Body relatively elongate, laterally-compressed anteriorly and becoming progressively distinctly-compressed posteriorly. Body depth at dorsal-fin origin approximately 0.21 0.22 of SL, and slightly shorter than HL. Lateral line on body complete, unbranched, and midlateral; extending from verti- cal through pectoral-fin base onto hypural plate with slight dorsal bend on hypural plate and with short, ventrally-directed branches on caudal peduncle extending off of main canal. Dorsal profile of body straight from nape to dorsal-fin origin and nearly straight from dorsal-fin origin to caudal-fin base. Ventral profile of body convex along abdomen, approximately straight, but posterodorsally-slanted, along base of anal fin. Caudal-peduncle depth greater than caudal-peduncle length.

Head in profile acutely triangular overall with bluntlyrounded snout. Dorsal profile of head gently convex from tip of snout to nape. Ventral profile of head slightly convex. Margin of snout in dorsal view rounded anteriorly and obtusely triangular overall. Postorbital margins of head running nearly in parallel from dorsal view. Enlarged jaw musculature not evident externally on dorsal surface of postorbital portion of head.

Opercular membrane attaching to isthmus only to region anterior to vertical through pectoral-fin insertion. Opercular opening moderate; extending ventral of pectoral-fin insertion by distance equal to width of orbit and extending dorsal of pectoral-fin insertion by distance equal to width of orbit.

Eye situated on lateral surface of head; located entirely dorsal to horizontal extending through pectoral-fin insertion; eye visible in dorsal view, but not in ventral view, of head. Middle of orbit at approximately anterior one-third of HL. Eye diameter slightly larger than one-half of snout length. Interorbital width approximately equal to distance from tip of snout to middle of eye. Anterior narial opening circular, surrounded by short, anteriorly-directed, tubular rim of skin. Opening of anterior nares located along horizontal extending through both tip of snout and maxillary-barbel origin. Distance between anterior nares approximately equal to snout length. Posterior narial opening located on dorsal surface of head, situated along vertical through anterior margin of orbit. Posterior narial opening nearly round with anterior two-thirds of aperture bordered by flap of skin, with anterior portion of flap highest.

Mouth inferior; its width approximately equal to distance from tip of snout to posterior margin of orbit and much less than one-half of HL. Margin of lower jaw gently rounded, its posterior limit reaching to vertical through middle of eye. Premaxillary tooth patch in form of gently-arched band, continuous across midline and with anterior margin convex and pos- 
terior margin concave and running in parallel to anterior margin. Teeth on premaxilla small, conical, sharply-pointed, and arranged in three, relatively regularly-arranged rows. Vomerine teeth arranged in single, irregular row continuous across midline. Vomerine teeth conical and stout, distinctly larger than those on premaxilla. Dentary teeth comparable in shape to, but longer than, premaxillary teeth. Dentary dentition consisting of two tooth rows at symphysis that taper to one row laterally.

Maxillary barbel slender, its length approximately equal to one-half of HL; barbel origin located ventral to middle of orbit. Mental barbels approximately equal in length to maxillary barbel and to each other. Medial mental-barbel origin located along vertical through rictus. Lateral mental-barbel origin situated slightly posterior of vertical through posterior margin of orbit. Tips of adpressed mental barbels falling just short of posterior margin of opercle.

Dorsal fin moderately large overall with length of dorsalfin base approximately 0.33 of HL. Length of longest branched dorsal-fin ray equal to two-thirds of HL. Dorsal-fin spinelet absent. First dorsal-fin ray not spinous, with moderately long filament in females and immature males and prolonged distal filament in mature males. Distal margin of dorsal fin straight other than for filament in presumed mature males, with first ray longest. Dorsal-fin origin located at approximately anterior $0.30-0.31$ of SL and along vertical extending through distal one-fourth of adpressed pectoral fin. Tip of adpressed dorsal fin, excluding distal filament on first ray in presumed mature males, reaching nearly to vertical through tip of adpressed pelvic fin. Posterior most dorsal-fin ray without posterior, membranous attachment to body.

Caudal fin deeply-forked, symmetrical; tips of lobes pointed. Length of longest caudal-fin ray approximately two times length of middle fin rays.

Base of anal fin moderately long. Anal-fin origin located well posterior of middle of SL, and slightly anterior to vertical through middle of TL. Anal-fin margin straight in females and immature males, with posterior most unbranched anal-fin ray longest and subsequent rays becoming gradually shorter. Anal-fin margin slightly convex in mature males. Posterior most anal-fin ray with posterior, membranous attachment to body along basal one-third of fin.

Pelvic fin moderately long; distal margin nearly straight, with first ray longest. Pelvic-fin insertion located far anterior of middle of SL and along vertical through posterior portion of base of dorsal fin. Tip of adpressed pelvic fin extending slightly beyond middle of SL but falling short of anterior limit of vent. Medial most pelvic-fin ray with membranous attachment to body along basal two-thirds of its length.

Pectoral-fin length approximately two-thirds of HL. Pectoral-fin margin very gently convex, with first ray longest. First pectoral-fin ray not spinous, without distal filament in females and immature males and with moderately-developed filament in mature males.

Coloration in alcohol. Head and body with scattered, dark pigmentation dorsal of lateral line, pigmentation somewhat more concentrated dorsally; dark pigmentation particularly apparent in smaller specimens collected in río Sinú basin, in which dark pigmentation extends further ventrally on head. Scattered, dark, pigmentation present on caudal peduncle and base of caudal fin. Dark pigmentation on head extending ventrally to level of horizontal running through eye, with additional dark pigmentation encircling orbit. Tip of snout unpigmented. Ventral surface of head and abdomen lacking dark pigmentation.

Dorsal fin with scattered, dark pigmentation basally and with dark pigmentation extending over approximately basal one-half of first interradial membrane. Caudal fin with scattered, dark pigmentation throughout, but overall fin not distinctly dusky. Pectoral, pelvic, and anal fins without dark pigmentation.

Maxillary barbel with dark pigmentation along lateral margin. Mental barbels pale, or with at most few dark chromatophores.

Coloration in life. Fowler (1943: 245) reported that Cetopsis othonops has a golden-yellow coloration in life.

Sexual dimorphism. Presumed mature males of Cetopsis othonops have longer filaments on the first ray of the dorsal and pectoral fins than are present in examined females and immature males of the species (filaments obvious in male holotype of the species illustrated by Eigenmann, 1923, pl. 3, fig. 1). The smallest examined male of the specimens in which an elongate filaments was present was $89 \mathrm{~mm} \mathrm{SL}$. The presumed mature males of $C$. othonops also have a convex margin to the anal fin contrary to the straight margin on that fin that characterizes females and immature males of the species.

Distribution. Cetopsis othonops is known from the Caribbean Sea versant río Magdalena and río Sinú basins of northwestern Colombia (Fig. 33).

Common Name. Colombia: "Baboso," "Bobo," "Ciego" (Miles, 1947: 86; Dahl, 1971: 65).

Material examined. 44 specimens (40 specimens, $40-110 \mathrm{~mm}$ SL). Colombia. Antióquia: río Cauca basin, Caucasia, El Jardim $\left(8^{\circ} 00^{`} \mathrm{~N}, 75^{\circ} 12^{\prime} \mathrm{W}\right)$, MZUSP 42207, 1 (79). Chocó: río Sinú tributary, at Tierralta, quebrada emptying $300 \mathrm{~m}$ below Urrá Hydroelectric Station (9³1'N, 77³3'W), NRM 36777, 2 (47-58). Tierralta, outlet of dam of Urrá Hydroelectric Station into río Sinú ( $9^{\circ} 31^{\prime} \mathrm{N}$, 77³3'W), NRM 39624, 1 (40). Cundinamarca: río Magdalena at Girardot (4 $\left.{ }^{\circ} 18^{\prime} \mathrm{N}, 7^{\circ} 49^{\prime} \mathrm{W}\right)$, CAS 64606, 6 (53-97, paratypes of Hemicetopsis othonops). Girardot $\left(4^{\circ} 18^{\prime} \mathrm{N}, 74^{\circ} 49^{\prime} \mathrm{W}\right)$, USNM 79213, 2 (55-78, paratypes of Hemicetopsis othonops); USNM 167853, 4 (65-94, paratypes of Hemicetopsis othonops); FMNH 56040, 1 (93, holotype of Hemicetopsis othonops, adult male). Apulo (now Rafael Reyes, $4^{\circ} 31^{\prime} \mathrm{N}, 7^{\circ} 36^{\prime} \mathrm{W}$ ), CAS 64607, 18 (50-110, paratypes of Hemicetopsis othonops); USNM 76972, 6 (53-93, paratypes of Hemicetopsis othonops, $89 \mathrm{~mm}$ specimen mature male; 1 specimen, $82 \mathrm{~mm}$, cleared and stained); FMNH 77885, 1 (91, adult male). Valle: río Cauca, near Cali $\left(3^{\circ} 27^{\prime} \mathrm{N}, 76^{\circ} 31^{\prime} \mathrm{W}\right)$, CAS 64608, 1 (75, paratype of Hemicetopsis othonops). 


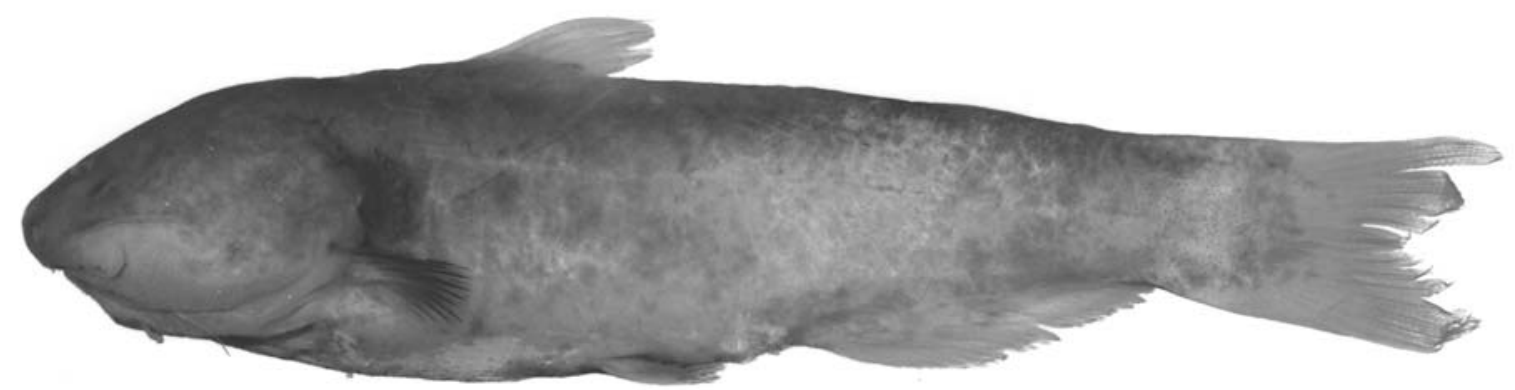

Fig. 35. Cetopsis parma, holotype, MUSM 2266, 73 mm SL; Peru, Ucayali, Provincia Coronel Portillo, río Tambo, Pucallpa, Atalaya $\left(8^{\circ} 23^{\prime} \mathrm{S}, 74^{\circ} 32^{\prime} \mathrm{W}\right)$.

Problematic Colombian localities: No specific locality, ANSP 83511, 1 (not measured as consequence of condition). El Quamo, upper río Magdalena basin (departamento unknown), USNM 100758, 1 (97).

\section{Cetopsis parma Oliveira, Vari, \& Ferraris, 2001} Figs. 33, 35, Tables 9-15

Cetopsis parma Oliveira et al., 2001: 575 [type locality: Peru, Departamento de Ucayali, Provincia Coronel Portillo, río Tambo, río Ucayali basin, Pucallpa, Atalaya $\left(8^{\circ} 23^{\prime} \mathrm{S}\right.$, $\left.74^{\circ} 32^{\prime} \mathrm{W}\right)$ ]. - Vari \& Ferraris, 2003: 257 [in check list, distribution].

Diagnosis. Cetopsis parma can be distinguished from all of its congeners by the combination of the presence of an eye, the conical teeth on the vomer and the dentary, the rounded posterior nares that is distinctly separated from the contralateral nares by a distance greater than the width of the posterior nares, the dark humeral spot, the pattern of a darkly pigmented pectoral and pelvic fins other than for thin, clear margins, and the possession of 23 to 25 total anal-fin rays.

Description. Body stout, slightly laterally compressed anteriorly, increasingly more so posteriorly. Body depth at dorsalfin origin approximately $0.24-0.27$ of SL, and slightly less than HL. Lateral line on body complete, unbranched, and midlateral; extending from vertical through pectoral-fin base to hypural plate. Dorsal profile of body straight and slightly obliquelyslanted from nape to dorsal-fin origin, straight from dorsal-fin origin to caudal-fin base. Ventral profile of body convex along abdomen, approximately straight, but posterodorsally-slanted, along base of anal fin. Caudal-peduncle depth slightly greater than caudal-peduncle length in holotype and single non-type specimen, slightly less than caudal-peduncle length in both much larger paratype (MEPN 1034) and non-type specimen that originated in rio Negro Basin (MZUSP 79993). Caudal peduncle distinctly-compressed transversely.

Head in lateral view triangular with bluntly-rounded snout. Dorsal profile of head gently convex from tip of snout to nape. Ventral profile of head convex. Profile of snout broadly rounded from dorsal view. Profiles of postorbital portion of each side of head running in parallel. Dorsal surface of postorbital part of head with enlarged jaw musculature obvious externally.
Opercular membrane attaching to isthmus as far posteriorly as vertical through pectoral-fin insertion. Opercular opening moderate; extending ventral of horizontal extending through pectoral-fin insertion for distance equal to snout length and extending dorsal of pectoral-fin insertion for distance slightly less than snout length.

Eye situated on dorsolateral surface of head; located one to two orbital diameters dorsal of horizontal extending through pectoral-fin insertion; eye visible in dorsal view, but not ventral view, of head. Middle of orbit located slightly anterior to limit of anterior one-fourth of HL. Eye diameter approximately one-third of snout length in holotype ( $73 \mathrm{~mm} \mathrm{SL}$ ), slightly less than one-third of snout length in smaller non-type specimen (ANSP 178105, $119 \mathrm{~mm} \mathrm{SL}$ ), approximately one-fourth of snout length in large non-type specimen collected in rio Negro basin (MZUSP 79993, $180 \mathrm{~mm} \mathrm{SL}$ ), and apparently proportionally of that size in paratype (MEPN 1034, $170 \mathrm{~mm} \mathrm{SL}$ ), albeit impossible to measure accurately as consequence of thicker integumentary layer overlying eye in that individual. Interorbital width distinctly larger than distance from tip of snout to posterior margin of orbit and approximately 0.4-0.5 of HL. Anterior narial opening circular, surrounded by short, anteriorly- to anteromedially-directed, tubular rim of skin and located along horizontal extending through both tip of snout and maxillary-barbel origin. Distance between anterior nares ranging from nearly equal to length of snout to nearly equal to distance from tip of snout to posterior margin of orbit. Posterior narial opening nearly round or slightly ovoid but without obvious long axis; located on dorsal surface of head and along vertical through anterior margin of orbit. Anterior two-thirds of posterior narial opening bordered by flap of skin; flap only slightly higher anteriorly. Distance between posterior nares less than distance between anterior nares.

Mouth inferior, its width approximately one-half of HL. Margin of lower jaw nearly transverse, its posterior limit reaching to vertical through posterior margin of orbit. Premaxillary tooth patch elongate and crescentic, continuous across midline; anterior margin convex and posterior margin transverselyaligned and nearly straight. Premaxillary teeth relatively small, conical, and sharply-pointed, with teeth arranged in four or five, irregular rows (five rows present in paratype, largest examined specimen). Vomerine teeth arranged in one gentlycurved row continuous across midline. Vomerine teeth large 
and bluntly conical. Dentary dentition consisting of one row of teeth similar in size and shape to dentition present on vomer.

Maxillary barbel slender, length of barbel ranges from approximately equal to snout length to equal to distance from tip of snout to posterior margin of orbit; barbel origin located along vertical through anterior margin of orbit. Undamaged mental barbels approximately equal in size and length to maxillary barbel and to each other. Medial mental-barbel origin located along vertical through posterior margin of orbit. Origin of lateral mental barbel located slightly posterior to vertical through posterior margin of orbit. Tips of adpressed mental barbels falling short of margin of branchial membranes.

Dorsal fin relatively small overall with length of base approximately $0.33-0.35$ of HL. Distal margin of dorsal fin straight, with first ray longest and equal in length to one-half of HL. Dorsal-fin spinelet absent. First dorsal-fin ray not spinous and with short, distal filament. Dorsal-fin origin located slightly posterior of one-third of SL and along vertical extending through distal one-fourth to one-half of adpressed pectoral fin. Tip of adpressed dorsal fin reaching to vertical through pelvic-fin insertion or slightly beyond that point. Posterior most dorsal-fin ray with variably-present, short, posterior, membranous attachment to body.

Caudal fin shallowly-forked and symmetrical; tips of lobes bluntly pointed. Length of longest caudal-fin rays approximately 1.5 times length of middle fin rays.

Base of anal fin relatively short, approximately 0.24-0.27 of SL. Anal-fin origin located well posterior to middle of SL and slightly posterior to middle of TL. Anal-fin margin straight. First branched anal-fin ray longest, with following rays becoming gradually shorter. Posterior most anal-fin ray without posterior, membranous attachment to body.

Pelvic fin short, with distal margin slightly convex and first branched ray longest. Pelvic-fin insertion located anterior to middle of SL and just posterior to vertical through posterior terminus of base of dorsal fin. Tip of adpressed pelvic fin extending beyond middle of SL, but falling short of anterior limit of vent. Medial most pelvic-fin ray with membranous attachment to body along its basal one-half.

Pectoral-fin length approximately one-half of HL. Pectoral-fin margin slightly sigmoid with first and middle fin rays longest. First pectoral-fin ray not spinous and with very short, distal filament.

Coloration in alcohol. Body slightly darker dorsally in holotype and paratype; distinctly darker overall in more recently preserved, non-type specimens. Sides of body darker as far ventrally as level of horizontal extending through pectoralfin base in holotype and paratype. Non-type specimens with irregular, mottled, dark pigmentation extending ventrally nearly to midventral line; dark pigmentation less concentrated ventral of horizontal extending through ventral limit of base of pectoral-fin insertion and in form of variablycoalesced spots slightly larger that orbital diameter. Abdomen in darkly pigmented specimens with only few scattered, dark spots. Postpelvic region of ventral portion of body in dark specimens heavily pigmented. Irregular, vertically-elongate, dark blotch present on lateral surface of body dorsal to basal one-half of pectoral fin in holotype and paratype; blotch not readily apparent in more recently-preserved, nontype specimens. Height of blotch approximately equal to length of pectoral fin in holotype, proportionally slightly higher in paratype.

Head somewhat darker dorsally in holotype and paratype, much more so in non-type specimens with dark pigmentation forming dense field extending ventrally to level of horizontal running through base of maxillary barbel. Non-type specimens with few (ANSP 178105) to many (MZUSP 79993) dark spots located ventral of horizontal extending through base of maxillary barbel, with dark pigmentation extending nearly to ventral midline, particularly along lower jaw. Snout margin dark in all specimens, more so in more recently-collected, nontype specimens. Ventral surface of head pale or with few scattered, dark spots.

Dorsal fin in holotype pale but irregularly covered with dark pigmentation in paratype. Non-type specimens with dark, parallel lines slanting across interradial membranes and with scattered, dark pigmentation at base of fin. Caudal fin pale in holotype but covered with scattered, eye-size, dark spots in other larger specimens. Non-type specimens with caudal fin as dark basally as caudal peduncle and with irregular fields of dark pigmentation extending onto each caudal-fin lobe; dark pigmentation becoming progressively less intense towards distal margin of fin. Anal fin dusky basally and pale distally in holotype and paratype, with irregular, dark, basal pigmentation in non-type specimens (particularly ANSP 178105) and with scattered, dark spots on distal portions of fin. Pectoral fin with interradial membranes darkly pigmented on dorsal surface except along fin margin; dark pigmentation more intense in non-type specimens. Pelvic fin of holotype and paratypes with scattered, dark pigmentation on dorsal surface of interradial membranes, except along fin margin. Non-type specimens with dark pigmentation on dorsal surface of interradial membranes except along fin margin.

Maxillary barbels dusky basally and pale distally. Mental barbels pale.

Sexual dimorphism. No evidence of sexual dimorphism comparable to that present in many species of the Cetopsinae was apparent among the four available specimens of Cetopsis parma.

Distribution. Cetopsis parma is only known from three definite localities in the western portions of the Amazon basin in Brazil, Ecuador, and Peru (Fig. 33) and one lot from an indefinite locality (ANSP 178165). It is likely that the last of these lots was collected in the vicinity of Iquitos, Peru (M. Sabaj, ANSP; pers. commun., 2002), a locality somewhat down river from the holotype locality.

Remarks. In their original description of Cetopsis parma, Oliveira et al. (2001: 575) noted that they assigned that spe- 
cies to Cetopsis on the basis of the traditional definition of that genus, but cautioned that ongoing phylogenetic studies might reveal that its relationships lay elsewhere within the Cetopsinae. The potential intrageneric phylogenetic relationships of the species could not be critically evaluated as a consequence of a lack of osteological information resulting from the absence of material of $C$. parma that could be cleared and stained, nonetheless it falls within the expanded concept of the genus Cetopsis utilized herein (see "Systematic Overview" above).

Oliveira et al. $(2001: 577,578)$ inconsistently reported that the holotype of Cetopsis parma had alternatively 25 and 18 branched anal-fin rays. Examination of the type series reveals that the holotype has 20 branched anal-fin rays and the paratype 18 branched anal-fin rays. In the original description of Cetopsis parma, Oliveira et al. (2001: 578) noted the distinct difference in the number of branched anal-fin rays (18 and the erroneous count of 25) in the two then available specimens of the species. The additional, non-type specimens examined in this study (ANSP 178105) has a count of 20 branched anal-fin rays that matches the value in the holotype.

Material examined. 4 specimens (3, 73-180 mm SL). Brazil. Amazonas: rio Tiquié, between settlements of Caruru and Boca de Sal, rio Uaupés basin (approximately $0^{\circ} 04^{\prime} 59^{\prime \prime} \mathrm{N}, 68^{\circ} 24^{\prime} 59^{\prime \prime} \mathrm{W}$ ), MZUSP 79993, 1 (180). Ecuador. Pastaza: río Pastaza basin, near río Chicherota, in vicinity of Montalvo ( $\left.2^{\circ} 04^{\prime} \mathrm{S}, 76^{\circ} 58^{\prime} \mathrm{W}\right), \mathrm{MEPN}$ 1034, 1 (170, paratype of Cetopsis parma). Peru. Ucayali: Provincia Coronel Portillo, río Tambo, Pucallpa, Atalaya ( $\left.8^{\circ} 23^{\prime} \mathrm{S}, 74^{\circ} 32^{\prime} \mathrm{W}\right)$, MUSM 2266, 1 (73, holotype of Cetopsis parma). Loreto: reportedly from region of Iquitos, ANSP 178105, 1 (119, purchased from fisherman for ornamental fishes in Iquitos (Belém)).

\section{Cetopsis pearsoni, new species}

Figs. 33, 36, Tables 9-15

Pseudocetopsis sp.-Lauzanne et al., 1991: 69 [Bolivia, Bolivian Amazon, region of Yucumo].

Diagnosis. Cetopsis pearsoni can be distinguished from all of its congeners by the combination of the presence of an eye, the conical teeth on the vomer and the dentary, the rounded posterior nares that is distinctly separated from the contralateral nares by a distance greater than the width of the posterior nares, the absence of a dark humeral spot, the presence of a posteriorly-rounded, variably-developed, bilobed patch of dark pigmentation at the base of the caudal fin, the absence of a spot of dark pigmentation on the base of the dorsal fin, the absence of prominent dark pigmentation along the membrane behind the first ray of the dorsal fin, and the combination of the presence of fine spotting on the dorsolateral and lateral surfaces of the body, and the lack of approximately eye-size, dark spots on the lateral surface of the body.

Description. Body moderately stout, slightly laterally compressed anteriorly and becoming progressively distinctly- compressed posteriorly. Body depth at dorsal-fin origin approximately 0.22 of SL, and distinctly shorter than HL. Lateral line on body complete, unbranched, and midlateral; extending from vertical through pectoral-fin base onto, and slightly upturned on, hypural plate and terminating prior to posterior margin of hypural plate. Dorsal profile of body nearly straight from nape to dorsal-fin origin and straight from dorsal-fin origin to caudal-fin base. Ventral profile of body convex along abdomen, approximately straight, but posterodorsally slanted, along base of anal fin. Caudal-peduncle depth slightly greater than caudal-peduncle length.

Head in profile acutely triangular overall with bluntlyrounded snout. Dorsal profile of head with rounded snout and then straight from above orbit to nape. Ventral profile of head slightly convex. Margin of snout in dorsal view bluntly triangular. Postorbital margins of head running nearly in parallel from dorsal view. Enlarged jaw musculature slightly evident externally on dorsal surface of postorbital portion of head.

Opercular membrane attaching to isthmus only in region anterior to vertical through pectoral-fin insertion. Opercular opening moderate; extending ventral of pectoral-fin insertion by distance equal to snout length and extending dorsal of pectoral-fin insertion by distance slightly less than snout length.

Eye situated on lateral surface of head; located entirely dorsal to horizontal extending through pectoral-fin insertion; eye visible in dorsal view, but not in ventral view, of head. Middle of orbit located at approximately anterior one-third of HL. Eye diameter approximately equal to one-half of snout length. Interorbital width approximately equal to distance from tip of snout to middle of eye. Anterior narial opening circular, surrounded by short, anteriorly-directed, tubular rim of skin. Opening of anterior nares located along horizontal extending through both tip of snout and maxillary-barbel origin. Distance between anterior nares approximately equal to snout length. Posterior narial opening located on dorsal surface of head, and situated along vertical through anterior margin of orbit; narial opening nearly round with anterior two-thirds of aperture surrounded by flap of skin with anterior portion of flap highest.

Mouth inferior; its width slightly less than one-half of HL. Margin of lower jaw gently rounded, its posterior limit reaching to vertical through posterior margin of orbit. Premaxillary tooth patch in form of gently-arched band continuous across midline and with anterior margin convex and posterior margin concave and running in parallel to anterior margin. Teeth on premaxilla small, conical, and sharply-pointed, with teeth arranged in three or four, irregular rows. Innermost row of premaxillary teeth slightly larger than those in other rows. Vomerine teeth arranged in single, irregular row continuous across midline. Vomerine teeth stout, conical, and much larger than teeth on premaxilla or dentary. Dentary teeth comparable in shape to, but larger in size than, premaxillary teeth, with three, irregularly-arranged rows medially that taper to one row laterally. 


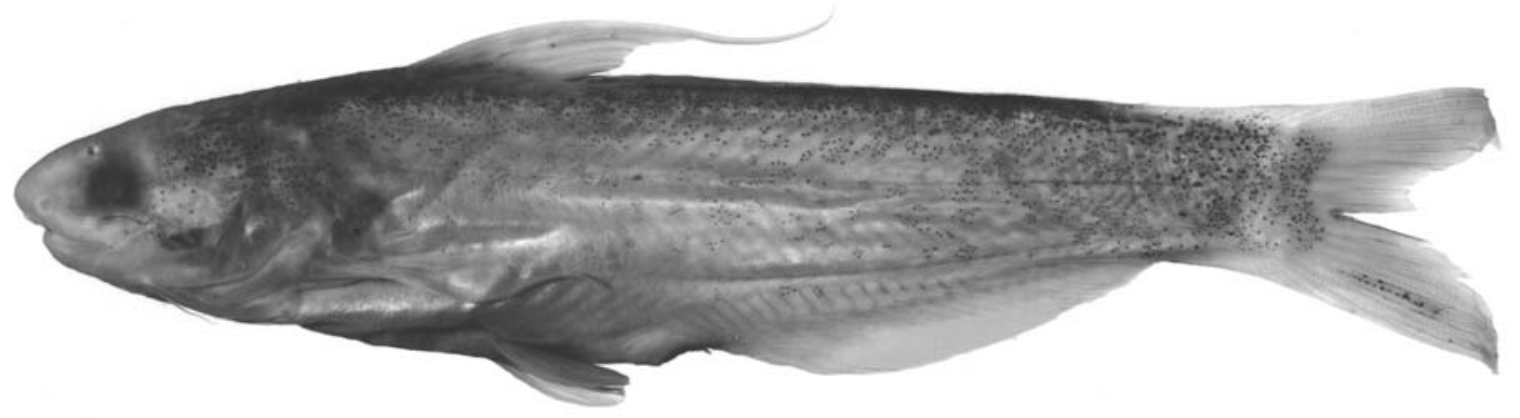

Fig. 36. Cetopsis pearsoni, new species, holotype, mature male, MUSM 11093, 90 mm SL; Peru, Puno, Provincia de Sandia, río

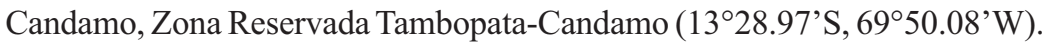

Maxillary barbel slender, its length greater than distance from tip of snout to posterior of orbit, but distinctly less than one-half of HL; barbel origin located ventral of middle of orbit. Mental barbels approximately equal in length to each other but shorter than maxillary barbel. Medial mental-barbel origin located along vertical through rictus. Lateral mental-barbel origin situated slightly posterior of vertical through medial mental-barbel origin. Tips of adpressed mental barbels falling far short of posterior margin of opercle.

Dorsal fin moderately large overall, with length of dorsalfin base approximately $0.40-0.42$ of HL. Length of longest branched dorsal-fin ray equal to two-thirds of HL. Dorsal-fin spinelet absent. First dorsal-fin ray not spinous and with distal filament in both sexes, but with filament proportionally longer in mature males (Fig. 36). Distal margin of dorsal fin concave, with first ray longest. Dorsal-fin origin located at approximately anterior $0.33-0.34$ of SL and along vertical extending through distal one-fourth of adpressed pectoral fin. Tip of adpressed dorsal fin, excluding distal filament on first fin ray, reaching nearly to vertical through vent. Posterior most dorsal-fin ray without posterior, membranous attachment to body.

Caudal fin shallowly-forked, symmetrical; tips of lobes pointed. Length of longest caudal-fin ray approximately 1.5 times length of middle fin rays.

Base of anal fin moderately long. Anal-fin origin located well posterior of middle of SL, and slightly anterior of vertical through middle of TL. Anal-fin margin straight in females and immature males with posterior most unbranched anal-fin ray longest, and subsequent rays becoming gradually shorter. Anal-fin margin slightly convex in mature males. Posterior most anal-fin ray without posterior, membranous attachment to body.

Pelvic fin moderate; distal margin nearly straight, with first ray longest. Pelvic-fin insertion located anterior to middle of SL and situated ventral to posterior one-half of base of dorsal fin. Tip of adpressed pelvic fin extending to vertical through middle of SL and falling short of anterior limit of vent. Medial most pelvic-fin ray with membranous attachment to body along basal two-thirds of its length.

Pectoral-fin length approximately two-thirds of HL. First pectoral-fin ray not spinous but prolonged into distal filament, filament very short in females and moderately-elongate in mature males (Fig. 36). Pectoral-fin margin sinusoidal overall with lateral portion concave and medial region convex.

Coloration in alcohol. Dorsal portion of head dark from interorbital region to posterior of head. Snout pale from tip to proximate to posterior nares. Lips and ventral portions of head pale. Dorsal portion of body dark. Lateral surface of body pale overall, but covered with fine, dark spots at least dorsolaterally. Fine, dark spots extending further ventrally in region above posterior one-half of base of anal fin and on caudal peduncle. Spots sometimes coalesce, but with conjoined spots distinctly smaller than size of eye. Ventral surface of body pale.

Dorsal fin with some scattered, dark pigmentation basally, but without distinct basal spot; darker specimens with dusky region extending further distally on fin. Remainder of dorsal fin pale. Caudal fin with scattered, dark pigmentation along base of principal fin-rays. Dark bilobed spot extending from base of branched fin rays posteriorly approximately to vertical through middle of length of innermost rays; spot more obvious in more darkly pigmented individuals. Remainder of caudal fin pale, but dusky in more darkly pigmented specimens. Pectoral and pelvic fins pale or with scattered pigmentation, dark on dorsal surfaces. Anal fin pale or with scattered, dark pigmentation basally.

Barbels dusky on basal one-half of anterior surface and otherwise pale.

Sexual dimorphism. Mature males of Cetopsis pearsoni have a filament on the first ray of the dorsal and pectoral fins that is proportionally more elongate than the comparable structures present in conspecific females. Mature males of the species also have slightly convex margins of the anal fin rather than the straight fin margin of conspecific females and immature males.

Distribution. Cetopsis pearsoni occurs in the upper portions of the rio Madeira drainage basin in southeastern Peru and northeastern Bolivia (Fig. 33). 
Etymology. The species name, pearsoni, is in honor of Nathan E. Pearson whose collecting efforts during 1921 in the region from which the species is known documented the high diversity of the ichthyofauna in that area.

Remarks. Perugia's (1897: 23) report of Cetopsis plumbeus as a component of the Bolivian ichthyofauna was evidently the basis for subsequent citations of that species for that fish fauna, in various genera, by Fowler $(1940 \mathrm{~b}$ : $97 ; 1945: 5)$ and Terrazas-Urquidi (1970: 21). The specimen that served as the basis for Perugia's citation was unavailable for examination during this study rendering a definitive identification of that material impossible. Although C. plumbea is indeed present in northeastern Bolivia, C. pearsoni, an externally similar species, also occurs in that region. As such Perugia's citation could potentially represent either of these two species.

An examination of at least some of the specimens that served as the basis for the citation of Pseudocetopsis sp. from various localities in Bolivia by Lauzanne et al. (1991: 69) demonstrated that they are Cetopsis pearsoni, a species that is described as new herein.

Chang (1998: 26) reported "Pseudocetopsis sp. n." from the río Tambopata and río Távara in the Tambopata-Candamo Reserved Zone, Madre de Dios, in southeastern Peru. It is likely that this report is based, at least in part, on the specimen that is herein designated as the holotype of Cetopsis pearsoni. That citation may, however, also be partially based on C. plumbea, a species that was also collected in, and reported from, those river systems by Chang (1998).

One specimen from considerably downstream of the known distribution of Cetopsis pearsoni either represents that species or a closely related, and possibly undescribed, form. That specimen cannot be definitively identified as a consequence of its condition (see comments concerning INPA 8485 in "Remarks" under C. montana).

Material examined. 13 specimens (38-114 mm SL). Holotype. Peru. Puno: Provincia de Sandia, río Candamo, Zona Reserva

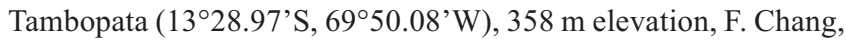
1 April 1997, MUSM 11093, 1, mature male (90). Paratypes. 11 specimens (50-114 mm SL). Bolivia, Beni: río Mamoré system, río Yacuma, San Borja (1409'S, 66 51 'W), L. Lauzanne \& G. Loubens, 1982, MNHN 1988-1995, 1 (110). Río Mamoré, Trinidad (1447’S, $64^{\circ} 47^{\prime}$ W), L. Lauzanne \& G. Loubens, 1984, MNHN 1988-2012, 1 (54). Cochabamba: río Mamoré, Chapare, Villa Tunari (1655'S, $\left.65^{\circ} 22^{\prime} \mathrm{W}\right)$, L. Lauzanne \& G. Loubens, 1982, MNHN 1988-1998, 3 (50-107, one mature male $70 \mathrm{~mm}$ SL). Río Mamoré, Chapare, Villa Tunari (16 $55^{\prime}$ 'S, $\left.65^{\circ} 22^{\prime} \mathrm{W}\right)$, L. Lauzanne \& G. Loubens, 20 Jun 1983, MZUSP 27812, 6 (57-114; 1 specimen, 59 mm, cleared and stained). Non-type specimen. 1 specimen (1, $38 \mathrm{~mm} \mathrm{SL}$ ). Bolivia Pando: no specific locality, FMNH 106906, 1 (38).

\section{Cetopsis plumbea Steindachner, 1882}

Figs. 33, 37-38, Tables 9-15

Cetopsis plumbeus Steindachner, 1882: 178 [type locality: [Ecuador] Canelos].-1883: 31, pl. 6, fig. 3 [more complete
description].-Boulenger, 1887: 276 [eastern Ecuador, Sarayacu].-Eigenmann \& Eigenmann, 1888: 157 [listing].1890: 318 [key and listing].-1891: 36 [listing].-Pearson, 1924: 16 [Bolivia, río Colorado, lower [río] Bopi].-1937a: 94 [Peru, río Marañon].-Fowler, 1941: 472 [Peru: río Marañon].-1945: 70 [Peru: río Marañon]. [Not Perugia, 1897: 23; Pearson, 1924: 16; Pearson, 1937b: 111; Fowler, 1940b: 97].

Cetopsis macroteronema Boulenger, 1898b: 6 [type locality: río Zamora, Equateur oriental (=eastern Ecuador)].Tortonese, 1940: 137 [type despository].

Pseudocetopsis macroteronema.-Eigenmann, 1910: 398 [in listing].--Gosline, 1945: 55 [listing].-Fowler, 1954: 5 [eastern Ecuador].-Ovchynnyk, 1967: 35 [Ecuador, río Zamora]; 1968: 255 [Ecuador, río Zamora].

Pseudocetopsis plumbeus plumbeus.-Schultz, 1944: 253 [key].Evers \& Seidel, 2002: 741 [listing]. [Not Cala, 1977: 11]

Hemicetopsis plumbeus.-Eigenmann \& Allen, 1942: 149 [literature compilation].--Gosline, 1945: 54 [listing].-TerrazasUrquidi, 1970: 21 [Bolivia]; Burgess, 1989: 292 [in listing]. Pseudocetopsis plumbeus.-Fowler, 1954: 5 [literature compilation].-Ovchynnyk, 1967: 35 [Ecuador: Sarayacu, Canelos]; 1968: 255 [Ecuador: Sarayacu, Canelos].Barriga, 1991: 57 [Ecuador, eastern drainages; common name]; 1994a: 31 [Ecuador, Parque Nacional Yasuni].-Saul, 1975: 117 [Ecuador, río Aguarico; food habits].-Ortega \& Vari, 1986: 15 [Peru; common name].-Stewart et al., 1987: 33 [Ecuador, based on Saul, 1975].--Ibarra \& Stewart [Ecuador, río Napo].- [Not Baskin et al., 1980: 184; Péfaur, 1988: 474].

Pseudocetopsis macropteronema.-Evers \& Seidel, 2002: 741 [listing; species name misspelled].

Pseudocetopsis plumbea.-Vari \& Ferraris, 2003: 258 [in check list; synonymy, distribution, common names].

Diagnosis. Cetopsis plumbea can be distinguished from all of its congeners by the combination of the presence of an eye, the conical teeth on the vomer and dentary, the rounded posterior nares that is distinctly separated from the contralateral nares by a distance greater than the width of the posterior nares, the wide mouth, the width of which is one-half of HL, the absence of a dark humeral spot, the absence of a posteriorly-rounded, variably-developed, bilobed patch of dark pigmentation at the base of the caudal fin, the absence of a pattern of dark pigmentation across the caudal fin other than for along its distal margin, the presence of approximately eye-size, dark spots on the lateral surface of the body, the presence of dark chromatophores along the anterior and lateral margins of the snout, the absence of dark pigmentation along the distal portions of the pectoral and anal fins, and the possession of 10 to 14 precaudal vertebrae and 45 to 50 total vertebrae.

Description. Body moderately-elongate, slightly-compressed laterally anteriorly and becoming progressively distinctlycompressed posteriorly. Body depth at dorsal-fin origin ap- 


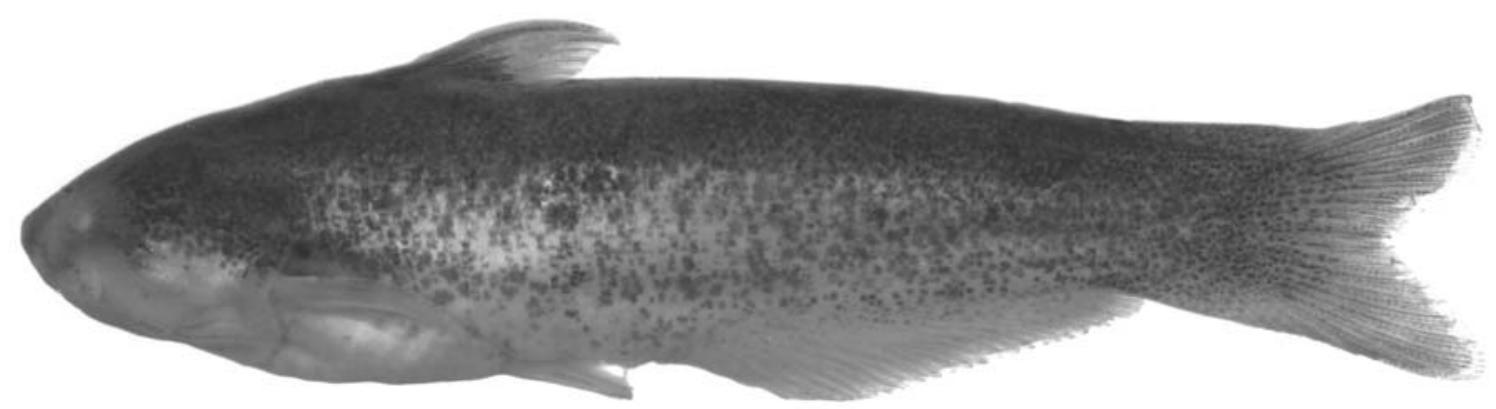

Fig. 37. Cetopsis plumbea, MUSM 11689, 64.1 mm SL; Peru, Puno, Carabaya, río Explanada, Zona Reservada TambopataCandamo $\left(13^{\circ} 24^{\prime} \mathrm{S}, 70^{\circ} 01^{\prime} 19^{\prime \prime} \mathrm{W}\right)$.

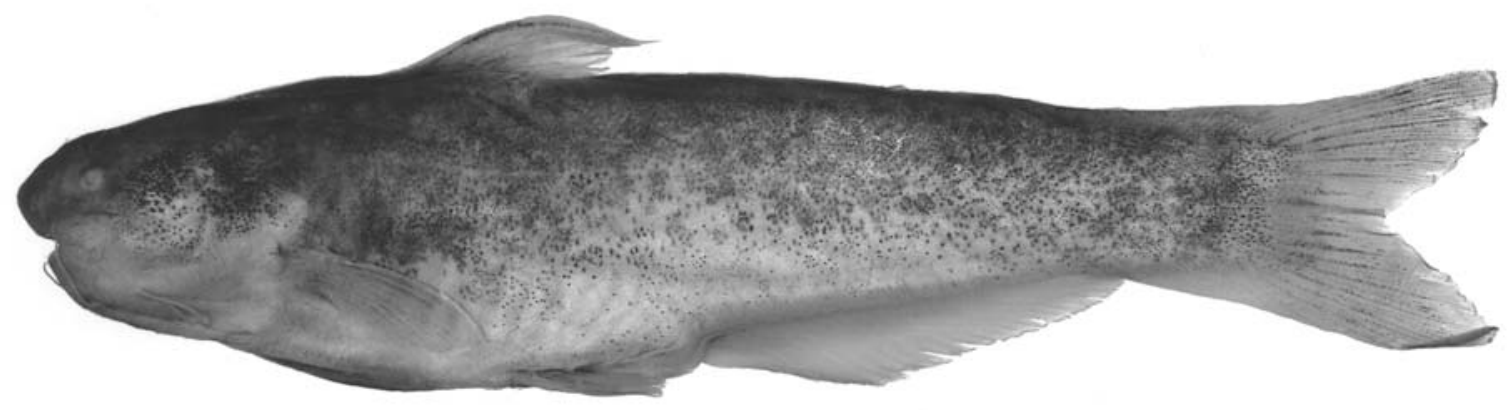

Fig. 38. Cetopsis plumbea, MEPN 1529, $78 \mathrm{~mm}$ SL; Ecuador, Zamora-Chinchipe, Playa del río Nangaritza, approximately $5 \mathrm{~km}$

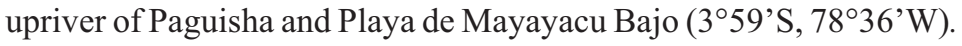

proximately $0.27-0.28$ of SL, and approximately equal to HL. Lateral line on body complete, unbranched, and midlateral; extending from vertical through pectoral-fin base to hypural plate with short, dorsal bend on hypural plate. Dorsal profile of body slightly convex from nape to dorsal-fin origin and nearly straight from dorsal-fin origin to caudal-fin base. Ventral profile of body convex along abdomen, approximately straight, but posterodorsally-slanted, along base of anal fin. Caudal-peduncle depth slightly greater than caudal-peduncle length.

Head in profile acutely triangular overall with bluntlyrounded snout. Dorsal profile of head slightly to distinctly convex from tip of snout to nape. Ventral profile of head slightly convex. Margin of snout in dorsal view rounded to bluntly triangular. Postorbital margins of head running nearly in parallel from dorsal view. Enlarged jaw musculature not apparent externally on dorsal surface of postorbital portion of head contrary to condition in some other species of the Cetopsinae.

Opercular membrane attaching to isthmus only anterior of vertical through pectoral-fin insertion. Opercular opening moderate; extending ventral of pectoral-fin insertion by distance equal to length of snout plus eye and extending dorsal of pectoral-fin insertion by distance slightly less than snout length.

Eye situated on lateral surface of head; located entirely dorsal to horizontal extending through pectoral-fin insertion; eye visible in dorsal view, but not in ventral view, of head.
Middle of orbit at approximately anterior 0.29 of HL. Eye diameter approximately one-half of snout length. Interorbital width approximately equal to distance from tip of snout to posterior margin of orbit. Anterior narial opening circular, surrounded by short, anteriorly-directed, tubular rim of skin. Opening of anterior nares located along horizontal extending through maxillary-barbel origin and ventral of horizontal extending through tip of snout. Distance between anterior nares approximately equal to snout length. Posterior narial opening located on dorsal surface of head, situated along vertical through anterior margin of orbit; narial opening rounded and with anterior two-thirds of aperture surrounded by flap of skin with anterior portion of flap highest.

Mouth inferior; its width approximately one-half of HL. Margin of lower jaw gently rounded, its posterior limit reaching to vertical through posterior margin of orbit. Premaxillary tooth patch in form of gently-arched band, continuous across midline and with anterior margin convex and posterior margin concave and running in parallel to anterior margin. Teeth on premaxilla small, conical, and sharply-pointed, with teeth arranged in three or four, irregular rows of uniform-sized teeth. Vomerine teeth arranged in single, irregular row continuous across midline. Vomerine teeth stout, conical, and much larger than teeth on premaxilla or dentary. Dentary teeth comparable in shape to, but larger in size than, premaxillary teeth. Dentary dentition consisting of two regular rows medially, that taper to one row laterally. 
Maxillary barbel slender, its length approximately equal to distance from tip of snout to posterior margin of eye, and approximately one-third of HL; barbel origin located ventral to middle of orbit. Medial mental barbel slightly shorter than lateral mental barbel with latter approximately equal in length to maxillary barbel. Medial mental-barbel origin located along vertical through rictus. Lateral mental-barbel origin situated slightly posterior of vertical through medial mental-barbel origin. Tips of adpressed mental barbels falling short of posterior margin of opercle.

Dorsal fin moderately large overall with length of dorsalfin base approximately $0.40-0.41$ of HL. Length of longest branched dorsal-fin ray equal to two-thirds of HL. Dorsal-fin spinelet absent. First dorsal-fin ray not spinous but with at least short, distal filament in mature males. Distal margin of dorsal fin straight, or nearly straight, with first ray longest. Dorsal-fin origin located at approximately anterior $0.27-0.28$ of SL and along vertical extending through middle of adpressed pectoral fin. Tip of adpressed dorsal fin reaching nearly to vertical through vent. Posterior most dorsal-fin ray without posterior, membranous attachment to body.

Caudal fin moderately-forked, symmetrical; tips of lobes bluntly pointed. Length of longest caudal-fin ray approximately 1.5 to 1.75 times length of middle fin rays.

Base of anal fin long. Anal-fin origin located slightly posterior of middle of SL. Anal-fin margin straight in females and immature males, with posterior most unbranched anal-fin ray longest and subsequent fin rays becoming gradually shorter. Anal-fin margin slightly convex in mature males. Posterior most anal-fin ray without posterior, membranous attachment to body.

Pelvic fin moderate; distal margin nearly straight, with first ray longest. Pelvic-fin insertion located anterior to middle of SL and along vertical through posterior portion of base of dorsal fin. Tip of adpressed pelvic fin extending approximately to middle of SL, and past anterior margin of vent. Medial most pelvic-fin ray with membranous attachment to body along basal two-thirds of its length.

Pectoral-fin length approximately two-thirds of HL. Pectoral-fin margin slightly convex, with first ray longest and prolonged into filament; filament proportionally longer in mature males. First pectoral-fin ray not spinous.

Coloration in alcohol. Coloration somewhat intraspecifically variable (Figs. 37, 38) with some specimens retaining grayish or silvery background coloration on body. Dark pigmentation covering dorsal portion of head from snout to rear of head. Irregular spot of variably-developed, dark pigmentation present posteroventral to orbit in all specimens from single population sample that originated in eastern Ecuador (ZMH 1671), but such dark pigmentation absent in all other examined material herein assigned to Cetopsis plumbea. Dorsal portion of body dark. Lateral surface of body irregularly covered with dark spots of pigmentation of variable sizes; with some individuals having spots nearly uniformly-distributed and others having irregular, dark spots up to size of eye, some of which coalesce to some varying degrees. Spots more concentrated dorsally. Ventral surface of head and body pale or with few dark spots.

Dorsal fin covered by dark pigmentation, with pigmentation more concentrated basally. Caudal fin covered with variably-developed, scattered, dark pigmentation except for narrow clear band along distal margins. Anal fin with scattered, dark pigmentation along base and with dark pigmentation extending varying distances onto fin, but with distal portions of fin usually pale and without distinct distal band on fin. Pectoral fin with scattered, dark pigmentation on at least anterior rays and with distal margin and posterior rays often pale. Pelvic fin with scattered, dark pigmentation on base and dorsal surface of first ray.

Maxillary barbel dusky basally with distal portion pale. Mental barbels pale.

Sexual dimorphism. The presumed males of Cetopsis plumbea have a distal filament on the first ray of the dorsal fin. That filament is absent in females and immature males of the species. Mature males also have the filament on the first pectoral-fin ray proportionally more elongate than the extension of the ray present in conspecific females and immature males. Mature males have an anal-fin margin that is distinctly convex contrary to the straight anal-fin margin that is characteristic of females and immature males of the species. The largest mature males of the species examined in this study are all smaller than the largest examined females.

Distribution. Cetopsis plumbea occurs in the western portions of the Amazon basin in eastern Ecuador, southeastern Peru, and northeastern Bolivia (Fig. 33).

Common Name. Ecuador: "Ciego" (Barriga, 1991: 57); Peru: "Canero" (Ortega \& Vari, 1986: 15).

Ecology. Saul (1975: 117) reported that Cetopsis plumbea (cited therein as Pseudocetopsis plumbeus) feeds on a variety of terrestrial and aquatic insects. It inhabits streams with moderate current and a depth of up to $1 \mathrm{~m}$, occurring within such streams in areas over sand substrates but lacking vegetation.

Remarks. Cetopsis plumbea is similar in overall appearance to $C$. gobioides, a species that inhabits various river systems in the eastern and southeastern portions of South America. As discussed under "Remarks" for C. gobioides, these two species can be distinguished by various features.

The very short original description of Cetopsis plumbeus by Steindachner (1882: 78) was uninformative as to the number of specimens that served as the basis for the description of the species, and that author briefly reported the type locality as "Canelos." In a subsequent redescription of the species, Steindachner (1883: 31, pl. 6, fig. 3) provided a more extensive description and accompanying illustration of C. plumbeus and expanded the locality information to "Canelos (Ecuador)," a location in the Amazon basin versant of that country. 
Two lots of specimens identified as Cetopsis plumbeus were located in the NMW collections (NMW 47381-3; NMW 47383-3) that match the locality information (Canelos) cited in the original description of the species. The two specimens forming NMW 47381-3 (52.8 mm SL, $60.8 \mathrm{~mm}$ TL; $62.6 \mathrm{~mm} \mathrm{SL}$, $\sim 70 \mathrm{~mm}$ TL) approximate the lengths for the two specimens ("6-7 Ctm" $(=\mathrm{cm})$ ) reported by Steindachner in his redescription of Cetopsis plumbeus (Steindachner, 1883: 31), allowing for rounding to the nearest centimeter. The date on the label associated with this lot (NMW 47381-3 is stated as "Juli 1883" (July, 1883; H. Wellendorf, NMW; pers. commun., 16 Oct 1998) which, if it both were correct and represented the date on which the sample was collected, would indicate that these specimens could not be syntypes of C. plumbeus inasmuch as the original description of that species appeared in 1882. It is, however, likely that 1883 represents the year when these specimens were accessioned into the NMW collections $(\mathrm{H}$. Wellendorf, NMW; pers. commun.,16 Oct 1998.) and we consequently consider these two specimens to be syntypes of Cetopsis plumbeus.

The label information associated with the second lot (NMW 47383-3) from Canelos has a notation "Knop, gez. T.VI.3" that indicated that Steindachner's illustrator, Konopitsky, used a specimen from that lot as the basis for an illustration (H. Wellendorf, NMW; pers. commun., 16 Oct 1998). The label information matches that associated with the illustration published by Steindachner (1883: 31, pl. 6, fig. 3) that was cited in the species account as "Taf. VI, fig. 3." The specimen illustrated by Steindachner (1883, pl. 6, fig. 3) was approximately $45 \mathrm{~mm}$ SL (specimen illustrated at two times natural size in that plate), a length very close to that of one of the three specimens (46 mm SL) in NMW 47383-3 (the other two specimens in the lot are 48 and $56 \mathrm{~mm} \mathrm{SL}$ ). Furthermore, the residual dark pigmentation present on this specimen matches the pattern that is present in the illustrated specimen. Although the acquisition date on the label is "1884.I" (=January 1884), this indicates that the material was entered into the NMW acquisition records on that date rather than demonstrating that the lot was received in 1884 (H. Wellendorf, NMW; pers. commun., 16 Oct 1998). Given the available information we designate the illustrated $46 \mathrm{~mm}$ SL specimen (NMW 47383-1) as the lectotype of Cetopsis plumbeus and the other syntypes thereby become paralectotypes (NMW 47381-2-3; NMW 47383-3).

Boulenger (1898: 6) described Cetopsis macroteronema based on two obviously mature males from the río Zamora of eastern Ecuador, a location relatively close to the type locality of Cetopsis plumbeus at Canelos, Ecuador. In his description of Cetopsis macroteronema, Boulenger limited his comparisons of that species to the original description of Cetopsis ventralis described Gill (1870: 95) with an erroneous stated type locality of "Maranon or Upper Amazon, and Napo Rivers" (see "Remarks" under Paracetopsis bleekeri concerning the reported type locality). Cetopsis ventralis is, however, a junior synonym of Paracetopsis bleekeri, a species endemic to the Pacific Ocean versant of Ecuador (see Re- marks" under Paracetopsis bleekeri). Paracetopsis bleekeri differs dramatically in a number of internal and external features from the complex of species, including Cetopsis macroteronema, that are externally similar to C. plumbea and in retrospect was an inappropriate basis of comparison for $C$. macroteronema. An examination of one of the syntypes of Cetopsis macroteronema (BMNH 1898.11.4.11) failed to reveal any differences between $C$. macroteronema and $C$. plumbea in the character systems examined in this study, and the two species are herein considered conspecific.

Schultz (1944: 253) placed two nominal forms (the Cetopsis orinoco and $C$. motatanensis of this study) as subspecies of Pseudocetopsis plumbeus without any discussion as to the basis for those subspecific assignments. The three nominal forms differ from each other in a number of often trenchant features and each is consequently herein considered to be a distinct species.

Cetopsis plumbeus was reported by Perugia (1897: 23) from the río Beni basin, with this record, in turn, apparently the basis for the inclusion of that species in the Bolivian fish fauna by Fowler (1945: 5) and Terrazas-Urquidi (1970: 21). Although Cetopsis plumbea does occur in the rivers of northeastern Bolivia, our results reveal that $C$. pearsoni also inhabits that drainage basins and we are, thus, unable to determine which of these two species served as the basis for the Perugia record and its reiteration by subsequent authors.

Cetopsis plumbea (under various generic combinations) has been reported from several areas distant from the known distribution of that species as documented by the specimens examined in this study. Following an examination of specimens that served as the basis of those records and/or given the locality from which the samples originated, we have been able to assign various of those citations to $C$. montana and C. pearsoni (see "Remarks" under those species). Ortega (1996: 471) cited Pseudocetopsis plumbeus from the Parque Nacional Manu in southeastern Peru. That locality is within the range of $C$. plumbea, but given that $C$. montana also occurs in the río Madre de Dios basin, we are unable to unequivocally determine which of these two species was present at the Parque Nacional Manu.

Cetopsis plumbea was reported from the TambopataCandamo Reserved Zone, also in the río Madre de Dios basin of southeastern Peru by Chang (1998: 26, cited therein as Pseudocetopsis plumbea). This record has been confirmed by the examination of a part of the series of specimens that served as the basis for that report of C. plumbea.

Material examined. 70 specimens (19-135.5 mm SL). Bolivia. La Paz: lower río Bopi (=Boopi), of río Colorado drainage system (approximately $\left.15^{\circ} 41^{\prime} \mathrm{S}, 67^{\circ} 15^{\prime} \mathrm{W}\right)$, CAS 16019, 4 (62-118; formerly IU 17255). Ecuador. Napo: río Pucuno, tributary of río Suno ( $\left.0^{\circ} 47^{\prime} \mathrm{S}, 7^{\circ} 16^{\prime} \mathrm{W}\right)$, USNM 163898, 2 (75-102). Río Aguarico at Santa Cecilia $\left(0^{\circ} 06^{\prime} \mathrm{N}, 76^{\circ} 51^{\prime} \mathrm{W}\right)$, ANSP 130604, 1 (27). Pastaza: río Curary [=Curaray], ZMH 1671, 8 (44-90). Canelos ( $\left.1^{\circ} 35^{\prime} \mathrm{S}, 77^{\circ} 45^{\prime} \mathrm{W}\right)$, NMW 47383-1, 1 (46; lectotype of Cetopsis plumbeus, designated herein); NMW 47381-1 and 3, 2 (52.8-62.6, 
paralectotypes of Cetopsis plumbeus); NMW 47383-2-3, 2 (4856, paralectotypes of Cetopsis plumbeus). Río Pastaza and río Pindo, Puyo, $1000 \mathrm{ft}$ elevation (1 $\left.{ }^{\circ} 28^{\prime} \mathrm{S}, 7^{\circ} 59^{\prime} \mathrm{W}\right), \mathrm{UMMZ}$ 203882, 1 (135.5). Río Payamino, $23.3 \mathrm{~km}$ upstream from mouth in río Napo, FMNH 111692, 1 (34). Río Payamino, $12.3 \mathrm{~km}$ upstream from mouth in río Napo FMNH 111693, 1 (30). Río Napo, río Suno, lower $0.5 \mathrm{~km}$ and at its mouth, FMNH 111694, 1 (37). Río Napo, río Arajuno, lower reaches, 1 (46). Río Tutapischco, just upstream from mouth in río Payamino, near San Jose de Payamino (0³0'S, $\left.77^{\circ} 18^{\prime} \mathrm{W}\right)$, FMNH 111696, 2 (80-81). Río Napo, río Arajuno, lower reaching, FMNH 111695, 1 (46). Sucumbios: río La Bermeja, in front of comunidad Shuar (approximately $\left.0^{\circ} 10^{\prime} \mathrm{N}, 76^{\circ} 25^{\prime} \mathrm{W}\right)$, MEPN 1528, 3 (43.5-69). Zamora Chinchipe: Playa del río Nangaritza approximately $5 \mathrm{~km}$ upriver of Paguisha and Playa de Mayayacu Bajo (359'S, 78³6'W), MEPN 1529, 1 (78). Río Zamora, BMNH 1898.11.4.11, 1 (89, syntype of Cetopsis macroteronema). Peru. Amazonas: río Marañon, vicinity of Balsas (6 $6^{\circ} 51.9^{\prime}$ S, 7759.9' W), ROM 55377, 1 (65). Río Marañon, Pusoc (Guayabamba) above Balsas, approximately $3700 \mathrm{ft}(=1128 \mathrm{~m})$ (locality at approximately 6 ${ }^{\circ} 53^{\prime} \mathrm{S}$, $78^{\circ} 00^{\prime} \mathrm{W}$ ), CAS 77025, 1 (47; formerly IU 17624). $500 \mathrm{~m}$ upriver from Caterpiza (latter locality is at $3^{\circ} 55^{\prime} \mathrm{S}, 77^{\circ} 42^{\prime} \mathrm{W}$ ), LACM 42010-1, 1 (65). Cajamarca: río Marañon, Tingo de Pauca, at the mouth of río Crisnejas ( $\left.7^{\circ} 21^{\prime} \mathrm{S}, 7^{\circ} 50^{\prime} \mathrm{W}\right)$, CAS 77026, 3 (57-80; formerly IU 17623). Cuzco: río Marcapata, Hacienda Cadena, FMNH 71024, 1 (122). Huancavelica: río Mantaro, Quintabamba, MUSM 6647, 1 (119). Puno: Carabaya, río Explanada, Zona Reservada Tambopata-Candamo (1324'S, 7001'19"W), MUSM 11689, 20 (50-92). Huanuco: río Llullapichis, approximately 2 km upstream from mouth (at río Pachitea) (9³9.9'S, 7457.9' W), ROM 55821, 1 (55). Madre de Dios: Mouth of río Carbon, below Atalaya on N/S road (12 $\left.{ }^{\circ} 53^{\prime} \mathrm{S}, 71^{\circ} 20^{\prime} \mathrm{W}\right)$, ANSP 143982, 1 (94); ANSP 143983, 1 (85.6); ANSP 151520, 1 (96.0). Alto Madre de Dios at Shintuya (12 $\left.{ }^{\circ} 40^{\prime} \mathrm{S}, 71^{\circ} 17^{\prime} \mathrm{W}\right)$, ANSP 143984, 3 (30-31); ANSP 143985, 2 (19-24). Manu, Parque Nacional Manu, Pakitza, Quebrada Pachija, MUSM 4201, 1 (71, specimen cleared and stained).

\section{Cetopsis sandrae, new species}

Figs. 39-41, Tables 9-15

Diagnosis. Cetopsis sandrae can be distinguished from all of its congeners by the combination of the presence of an eye, the conical teeth on the vomer and the dentary, the rounded posterior nares that is distinctly separated from the contralateral nares by a distance greater than the width of the posterior nares, the absence of a dark humeral spot, the presence of a posteriorly-rounded, variably-developed, bilobed patch of dark pigmentation at the base of the caudal fin, the presence of a spot of dark pigmentation on the base of the dorsal fin with prominent dark pigmentation present along the membrane behind the first ray of the dorsal fin, the possession of 40 or 41 total vertebrae (with 40 most common), the lack of a distinct demarcation between the dark pigmentation on the dorsal and dorsolateral surfaces of the body versus more ventral regions, and the presence of eye size or larger, dark spots on the ventral and ventrolateral surfaces of the body in the region below the horizontal extending through the ventral margin of the caudal peduncle.
Description. Body moderately stout, slightly-compressed laterally anteriorly and becoming progressively distinctlycompressed posteriorly. Body depth at dorsal-fin origin approximately $0.29-0.30$ of SL, and slightly greater than HL. Lateral line on body complete, unbranched, and midlateral; extending from vertical through pectoral-fin base to hypural plate. Dorsal profile of body slightly convex from nape to dorsal-fin origin and nearly straight from dorsal-fin origin to caudal-fin base. Ventral profile of body convex along abdomen, approximately straight, but posterodorsally-slanted, along base of anal fin. Caudal-peduncle depth slightly greater than caudal-peduncle length.

Head in profile acutely triangular overall with bluntlyrounded snout. Dorsal profile of head slightly convex from tip of snout to nape. Ventral profile of head slightly convex. Margin of snout in dorsal view bluntly triangular. Postorbital margins of head aligned nearly in parallel from dorsal view. Enlarged jaw musculature apparent externally on dorsal surface of postorbital portion of head.

Opercular membrane attaching to isthmus only anterior of vertical through pectoral-fin insertion. Opercular opening moderate; extending ventral of pectoral-fin insertion by distance equal to distance from tip of snout to middle of eye and extending dorsal of pectoral-fin insertion by distance approximately equal to snout length.

Eye situated on lateral surface of head; located entirely dorsal to horizontal extending through pectoral-fin insertion; eye visible in dorsal view, but not in ventral view, of head. Middle of orbit at approximately anterior 0.30 of HL. Eye diameter approximately one-half of snout length. Interorbital width approximately equal to distance from tip of snout to posterior margin of orbit. Anterior narial opening circular, surrounded by short, anteriorly-directed, tubular rim of skin. Opening of anterior nares located along horizontal extending through maxillary-barbel origin and ventral of horizontal extending through tip of snout. Distance between anterior nares approximately equal to snout length. Posterior narial opening located on dorsal surface of head, situated along vertical through anterior margin of orbit; narial opening nearly round, with anterior two-thirds of aperture surrounded by flap of skin with anterior portion of flap highest.

Mouth inferior; its width approximately one-half of HL. Margin of lower jaw gently rounded, its posterior limit reaching to vertical through posterior margin of orbit. Premaxillary tooth patch in form of gently-arched band, continuous across midline and with anterior margin convex and posterior margin concave and running in parallel to anterior margin. Teeth on premaxilla small, conical, sharply-pointed, uniform-sized, and arranged in three regular rows. Vomerine teeth arranged in single irregular row apparently continuous across midline. Vomerine teeth stout, conical, and much larger than teeth on premaxilla and approximately as large as largest teeth on dentary. Dentary teeth comparable in shape to, but larger in size than, premaxillary teeth. Dentary dentition consisting of two or three irregular rows medially that taper to one row laterally. 


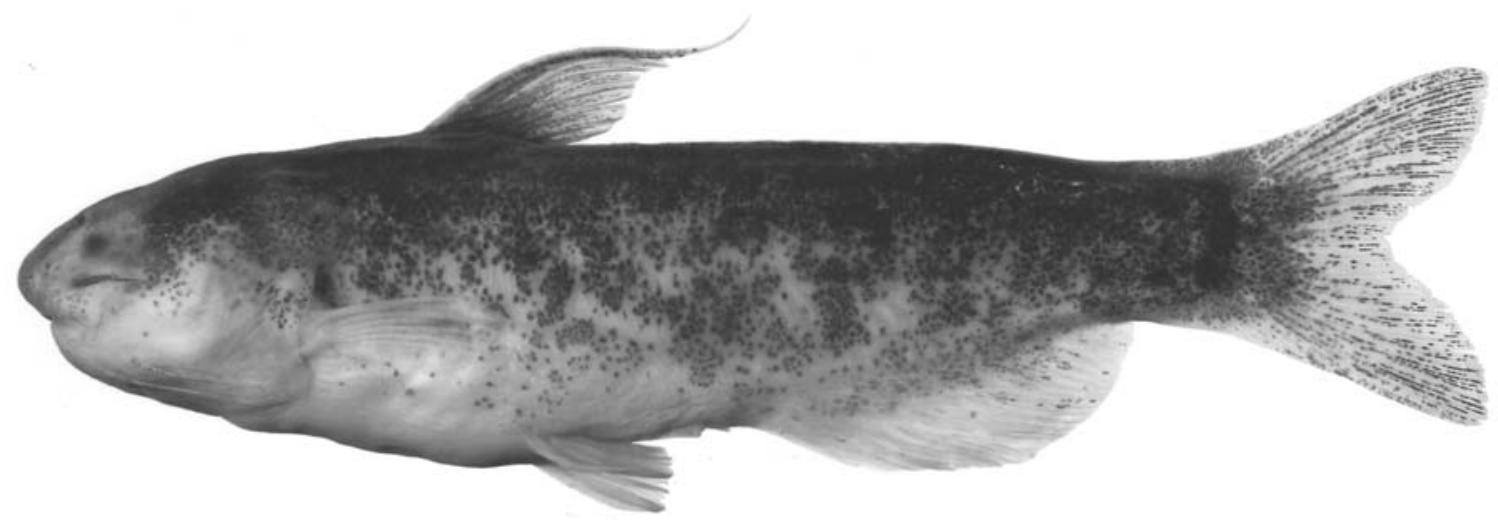

Fig. 39. Cetopsis sandrae, new species, holotype, male, MZUSP 61091, 64 mm SL; Brazil, Mato Grosso, Nova Mutum, unnamed Córrego, Fazenda Buriti (1351’52"S, 56¹1’36"W).

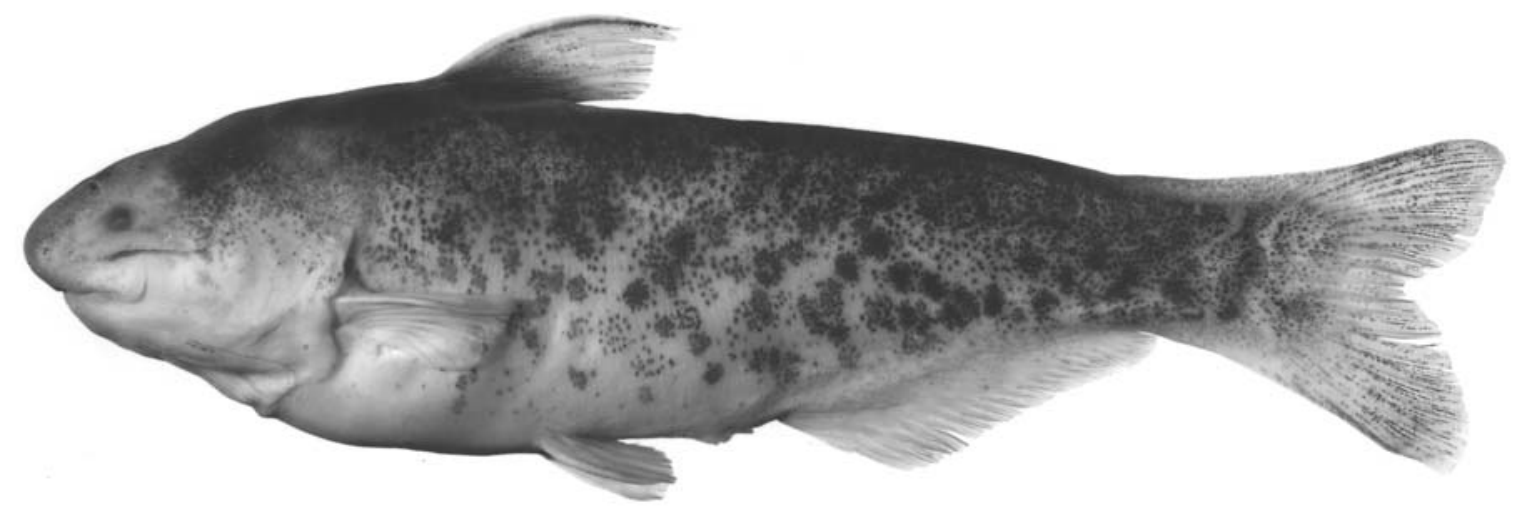

Fig. 40. Cetopsis sandrae, new species, paratype, female, MZUSP 83227, 75 mm SL; Brazil, Mato Grosso, Nova Mutum,

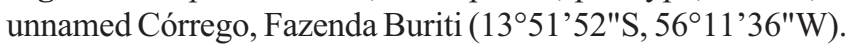

Maxillary barbel slender, its length approximately equal to distance from tip of snout to posterior margin of eye, and nearly one-half of HL; barbel origin located ventral to middle of orbit. Medial mental barbels approximately same length as lateral mental barbels and slightly shorter than maxillary barbels. Medial mental-barbel origin located along vertical through rictus. Lateral mental-barbel origin situated slightly posterior of vertical through medial mental-barbel origin. Tips of adpressed mental barbels falling just short of posterior margin of opercle.

Dorsal fin moderately large overall with length of dorsalfin base approximately $0.40-0.41$ of HL. Longest branched dorsal-fin ray, excluding distal filament on first ray, equal in length to two-thirds of HL. Dorsal-fin spinelet absent. First dorsal-fin ray not spinous but with at least short, distal filament in all specimens, and with filament proportionally longer in apparently mature males (Fig. 39). Distal margin of dorsal fin slightly sinusoidal with anterior portion concave and posterior portion convex. Dorsal-fin origin located at approximately anterior $0.36-0.37$ of SL and along vertical extending through middle of adpressed pectoral fin. Tip of adpressed dorsal fin, excluding filament, nearly reaching to vertical through vent. Posterior most dorsal-fin ray without posterior, membranous attachment to body.
Caudal fin moderately-forked, symmetrical; tips of lobes rounded. Length of longest caudal-fin ray approximately 1.75 times length of middle fin rays.

Base of anal fin moderately long. Anal-fin origin located distinctly posterior of middle of SL and nearly at middle of TL. Anal-fin margin straight in females (Fig. 40) and immature males, with posterior most unbranched anal-fin ray longest and with subsequent rays becoming gradually shorter. Analfin margin convex in mature males (Fig. 39) and in apparently maturing male of $45 \mathrm{~mm} \mathrm{SL}$ that does not demonstrate other sexually-dimorphic male characteristics of dorsal and pectoral fins. Posterior most anal-fin ray without posterior, membranous attachment to body.

Pelvic fin moderately long; distal margin distinctly convex, with first ray longest. Pelvic-fin insertion located anterior to middle of SL and along vertical through posterior terminus of base of dorsal fin. Tip of adpressed pelvic fin extending past middle of SL, but falling short of anterior margin of vent. Medial most pelvic-fin ray with membranous attachment to body along basal two-thirds of its length.

Pectoral-fin length approximately 0.60 of HL. Pectoral-fin margin slightly convex, with first ray longest and prolonged into filament, filament proportionally longer in mature males. First pectoral-fin ray not spinous. 


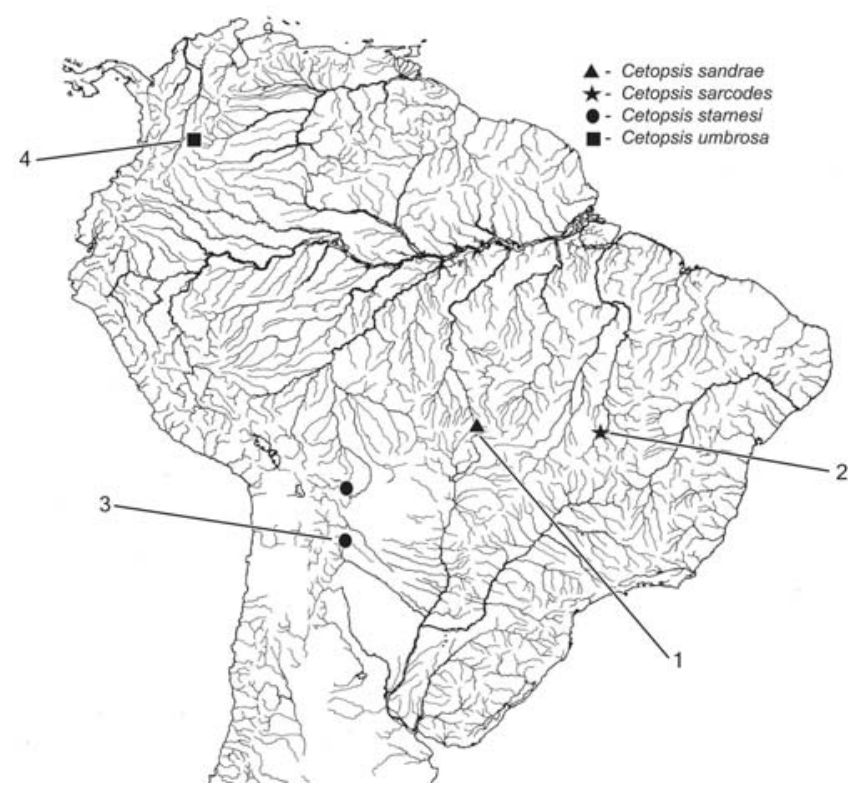

Fig. 41. Map of central and northern South America showing geographic distribution of Cetopsis sandrae $(1=$ holotype locality), Cetopsis sarcodes ( 2 = holotype locality), Cetopsis starnesi $(3$ = holotype locality), and Cetopsis umbrosa (4 = holotype locality) (some symbols represent more that one locality and/or lot of specimens).

Coloration in alcohol. Dark pigmentation covering dorsal portion of head from tip of snout to posterior margin of head. Dark, dorsal pigmentation continuous with dark region posterodorsal and posterior to orbit. Remaining portions of head pale. Dorsal portion of body dark. Lateral surface of body irregularly covered with fine, dark spots; spots often coalesce into eye-size blotches, with such coalescence more prevalent ventral of lateral line. Heavily pigmented individuals with lateral surface of body nearly uniformly dark. Ventral surface of body pale, with few, scattered, dark spots present only in most heavily pigmented individuals.

Dorsal fin irregularly covered with dark pigmentation; pigmentation more concentrated basally and forming semicircular dark spot above base of fin. Anterior margin and distal portions of dorsal fin pale, but with dark pigmentation along first interradial membrane. Caudal-fin rays outlined by scattered, dark pigmentation except for narrow, clear band along distal margin of fin. Anal fin with scattered, dark pigmentation along base and with dark pigmentation rarely extending varying distances onto main body of fin. Pectoral fin pale other than for occasional dark pigment spots on basal or distal portions of first fin ray. Pelvic fin pale.

Maxillary and mental barbel dusky basally and with distal portion pale.

Sexual dimorphism. Mature males of Cetopsis sandrae have the filaments on the first rays of the dorsal and pectoral fins proportionally more elongate than are the extensions on those ray in conspecific females and immature males. Males of $C$. sandrae also have the anal-fin margin distinctly convex rather than straight as occurs in females and immature males of that species.

Ecology. The holotype of Cetopsis sandrae and the paratypes of the species collected with it were collected in a relatively fast-flowing forest stream, approximately 3-4 $\mathrm{m}$ wide and 0.4$0.8 \mathrm{~m}$ deep with a small waterfall. All the samples were collected in riffles along the stream (F.C.T. Lima, MZUSP; pers. commun., 2003).

Distribution. Cetopsis sandrae is known only from the rio Arinos in the upper portions of the rio Tapajós system, Amazon basin (Fig. 41)

Etymology. The specific name, sandrae, is in reference to Sandra J. Raredon, of the Division of Fishes, National Museum of Natural History, in thanks for all of her assistance to the authors, particularly the first author, over the course of the years in this and many other projects.

Material examined. 6 specimens (6, 45-75 mm SL). Holotype. Brazil. Mato Grosso: Nova Mutum, unnamed córrego, Fazenda Buriti, approximately $1.5 \mathrm{~km} \mathrm{~S}$ of Fazenda (13 ${ }^{\circ} 51^{\prime} 52^{\prime \prime} \mathrm{S}$, 5611'36"W), MZUSP Ichthyology students, 16 February 2000, MZUSP 61091, 1, mature male (64). Paratypes. 5 specimens (5, 45-75 mm SL). Brazil. Mato Grosso: Nova Mutum, unnamed córrego, Fazenda Buriti, approximately $1.5 \mathrm{~km} \mathrm{~S}$ of Fazenda, collected with holotype, MZUSP 83227, 3 (45-75); USNM 372766 , 1 (63). Nova Mutum, riacho tributary to rio Arinos, Fazenda Buriti, MZUSP Ichthyology students, 20 Feb 2000, MZUSP 61051, 1 (46, cleared and stained).

\section{Cetopsis sarcodes, new species}

Figs. 41-42, Tables 9-15

Diagnosis. Cetopsis sarcodes can be distinguished from all of its congeners by the combination of the presence of an eye, the conical teeth on the vomer and the dentary, the rounded posterior nares that is distinctly separated from the contralateral nares by a distance greater than the width of the posterior nares, the presence of a humeral spot, the lack of a pattern of dark pigmentation across the pectoral and pelvic fins other than for a thin clear margin on each fin, the absence of distinct, dark pigmentation on the anal and caudal fins particularly on the distal portions of those fins, and the possession of 21 branched anal-fin rays, 28 caudal vertebrae, 43 total vertebrae, 25 total anal-fin rays, and 9 pectoral-fin rays.

Description. Body stout, somewhat laterally compressed anteriorly, becoming increasingly compressed posteriorly. Body depth at dorsal-fin origin approximately 0.31 of SL and equal to HL. Lateral line on body complete, unbranched, and midlateral; extending from vertical through pectoral-fin base to hypural plate. Dorsal profile of body slightly convex and obliquely-slanted from nape to dorsal-fin origin, straight from dorsal-fin origin to caudal-fin base. Ventral profile of body 


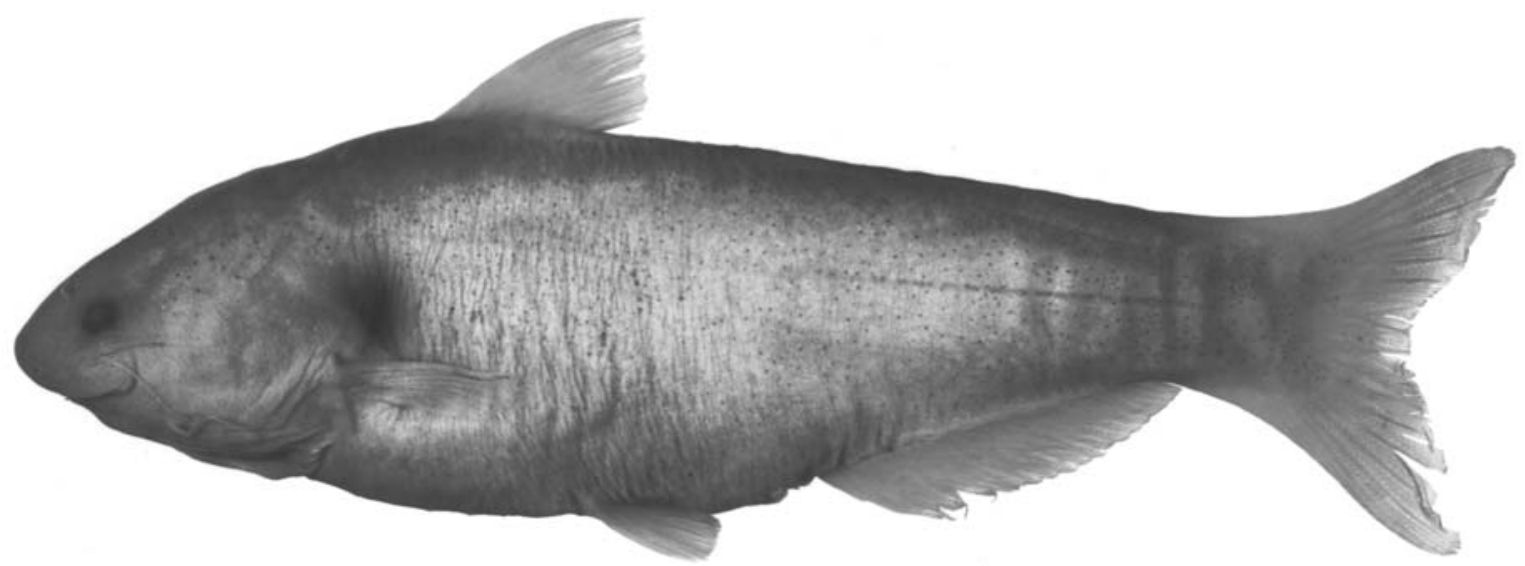

Fig. 42. Cetopsis sarcodes, new species, holotype, MNRJ 13024, 69 mm SL; Brazil, Goiás, Município de Minaçu/Cavalcante, rio Tocantins between site of future dam of Usina Hidroeléctrica Cana Brava and Ilha do Orgulho and Porto do Garimpo.

convex along abdomen, approximately straight, but posterodorsally-slanted, along base of anal fin. Caudal-peduncle depth approximately equal to caudal-peduncle length.

Head in lateral view acutely triangular with bluntly-rounded snout. Dorsal profile of head slightly convex from tip of snout to vertical through anterior margin of eye, nearly straight from that line to nape. Ventral profile of head convex. Profile of snout bluntly triangular in dorsal view. Width of postorbital portion of head gradually increases posteriorly. Dorsal surface of postorbital part of head with enlarged jaw musculature evident externally but not pronounced.

Opercular membrane attaching to isthmus as far posteriorly as vertical through pectoral-fin insertion. Opercular opening moderate, extending ventral of horizontal extending through pectoral-fin insertion for distance equal to snout length and dorsal of that level for distance approximately two-thirds of snout length.

Eye situated on lateral surface of head; located dorsal of horizontal extending through pectoral-fin insertion; eye visible in dorsal view, but not in ventral view, of head. Middle of orbit located at slightly less than anterior one-third of HL. Eye diameter approximately one-half of snout length. Interorbital width approximately equal to distance from tip of snout to middle of eye. Anterior narial opening circular, surrounded by short, anteriorly-directed, tubular rim of skin. Opening of anterior nares located along horizontal extending through maxillary-barbel origin. Distance between anterior nares approximately equal to distance from tip of snout to middle of eye. Posterior narial opening located on dorsal surface of head along vertical through anterior margin of orbit; opening approximately round and without obvious long axis. Anterior two-thirds of posterior narial opening bordered by approximately uniformly high flap of skin. Distance between contralateral posterior nares slightly less than distance between contralateral anterior nares.

Mouth inferior, its width slightly less than one-half of HL. Margin of lower jaw broadly rounded, its posterior limit reaching to vertical through posterior margin of eye. Premaxillary tooth patch elongate, crescentic, and continuous across mid- line; anterior margin convex, posterior margin transverselyaligned along medial portion of tooth patch and angled posteriorly along lateral portion of patch. Premaxillary teeth relatively small, conical, and sharply-pointed, with teeth arranged in five irregularly-arranged rows medially that taper to two rows laterally. Teeth of uniform size across jaw. Vomerine teeth large, bluntly conical, and arranged in one irregular, anteriorly-convex row. Dentary dentition consisting of two rows of teeth. Primary tooth row on dentary formed of large, conical teeth slightly smaller than the teeth on the vomer. Second tooth row shorter and consisting of series of smaller teeth extending laterally from symphysis anterior to the primary tooth row. Teeth of primary row on dentary slightly smaller than those on vomer.

Maxillary barbel slender, its length approximately equal to distance from tip of snout to posterior margin of orbit; barbel origin located along vertical through anterior margin of orbit. Mental barbels approximately equal in size and length, but slightly shorter than maxillary barbel. Medial mental-barbel origin located along vertical through rictus. Origin of lateral mental barbel located slightly posterior of vertical through medial mental-barbel origin. Tips of adpressed mental barbels falling short of posterior margin of opercle.

Dorsal fin moderately large sized with length of dorsal-fin base approximately $0.40-0.43$ of HL. Length of longest dorsalfin ray equal to length of postorbital region of head. Dorsalfin spinelet absent. First dorsal-fin ray not spinous; without distal, filament in single available, apparently juvenile, specimen. Distal margin of dorsal fin straight, with first ray longest. Dorsal-fin origin located at approximately anterior onethird of SL and along vertical extending through middle of adpressed pectoral fin. Tip of adpressed dorsal fin reaching to vertical through middle of adpressed pelvic fin. Posterior most dorsal-fin ray without posterior, membranous attachment to body.

Caudal fin shallowly-forked and symmetrical; tips of lobes bluntly pointed. Length of longest caudal-fin ray approximately 1.5 times length of middle fin rays.

Base of anal fin moderately long, slightly more than one- 
fourth of SL. Anal-fin origin located well posterior of middle of SL and slightly posterior to middle of TL. Anal-fin margin straight, with first branched anal-fin ray longest and subsequent rays becoming gradually shorter. Posterior most analfin ray without posterior, membranous attachment to body.

Pelvic fin short, with distal margin distinctly convex and first branched ray longest. Pelvic-fin insertion located anterior to middle of SL and slightly posterior to vertical through posterior portion of base of dorsal fin. Tip of adpressed pelvic fin extending beyond middle of SL and falling far short of vent. Medial most pelvic-fin ray with membranous attachment to body along basal one-half of its length.

Pectoral-fin length approximately one-half of HL. Pectoral-fin margin convex with first ray longest. First pectoral-fin ray not spinous and without distal filament in single available, apparently juvenile, male.

Coloration in alcohol. Overall head and body pale, with scattered, fine, dark pigment spots scattered over dorsal and lateral surfaces of head and body. Ventral surface of head and abdomen pale. Tip of snout pale. Diffuse, dark humeral spot present on lateral surface of body dorsal to basal one-half of pectoral fin.

Dorsal, anal, and pectoral fins pale. Caudal fin with scattered, fine, dark pigmentation present at base and on basal portions of principal fin rays.

Maxillary barbel with fine, dark pigmentation basally and otherwise pale. Mental barbels pale.

Sexual dimorphism. The single available specimen of Cetopsis sarcodes is apparently a male based on the form of the genital papilla, but lacks the distal filaments of the first rays of both the dorsal and pectoral fins and the convex margin to the anal fin that are typical of mature males of many other species of the Cetopsinae. This combination of features indicates that the holotype is probably an immature male.

Distribution. Cetopsis sarcodes is known only from the type locality in the rio Tocantins basin of eastern Brazil (Fig. 41).

Etymology. The species name, sarcodes, from the Greek, sarkos, for fleshy, refers to the rotund body form of this species.

Material examined. 1 specimen (69 mm SL). Holotype. Brazil. Goiás: Município de Minaçu/Cavalcante, rio Tocantins between site of future dam of Usina Hidroeléctrica Cana Brava and Ilha do Orgulho and Porto do Garimpo, D. F. Moraes Jr. et al., 10 December 1987, MNRJ 13024, 1 (69)

\section{Cetopsis starnesi, new species} Figs. 41, 43, Tables 9-15

Diagnosis. Cetopsis starnesi can be distinguished from all of its congeners by the combination of the presence of an eye, the conical teeth on the vomer and the dentary, the rounded posterior nares that is distinctly separated from the contralat- eral nares by a distance greater than the width of the posterior nares, the absence of a dark humeral spot, the presence of a posteriorly-rounded, variably-developed, bilobed patch of dark pigmentation at the base of the caudal fin, the absence of a spot of dark pigmentation on the base of the dorsal fin, the absence of prominent dark pigmentation along the membrane behind the first ray of the dorsal fin, the presence of approximately eye-size, dark spots on the lateral surface of the body, the absence of finely-scattered, dark pigmentation across the lateral and anterior surfaces of the snout, and the possession of 22 or 23 branched anal-fin rays. It is further distinguished from the externally very similar C. umbrosa in the number of precaudal vertebrae (11 or 12 versus 14 , respectively), caudal vertebrae (33 versus 30 , respectively), and total anal-fin rays ( 27 or 28 versus 26 , respectively).

Description. Body moderately stout, slightly laterally-compressed anteriorly and becoming progressively distinctlycompressed posteriorly. Body depth at dorsal-fin origin approximately 0.24 of SL and approximately equal to HL. Lateral line on body complete, unbranched, and midlateral; extending from vertical through pectoral-fin base onto, and very slightly upturned on, hypural plate and terminating prior to posterior margin of hypural plate. Dorsal profile of body approximately straight from nape to dorsal-fin origin and straight from dorsal-fin origin to caudal-fin base. Ventral profile of body convex along abdomen, approximately straight, but posterodorsally-slanted, along base of anal fin. Caudal-peduncle depth approximately equal to, or slightly greater than, caudal-peduncle length.

Head in profile acutely triangular overall with bluntlyrounded snout. Dorsal profile of head slightly convex anteriorly and straight from posterior limit of snout to nape. Ventral profile of head slightly convex. Margin of snout bluntly triangular in dorsal view. Postorbital margins of head running nearly in parallel from dorsal view. Enlarged jaw musculature slightly evident externally on dorsal surface of postorbital portion of head.

Opercular membrane attaching to isthmus only to region anterior to vertical through pectoral-fin insertion. Opercular opening moderate; extending ventral of pectoral-fin insertion by distance equal to distance from tip of snout to posterior margin of orbit, and extending dorsal of pectoral-fin insertion by distance slightly less than snout length.

Eye situated on lateral surface of head; located entirely dorsal to horizontal extending through pectoral-fin insertion; eye visible in dorsal view, but not in ventral view, of head. Middle of orbit located at approximately anterior one-fourth of HL. Eye diameter approximately two-thirds of snout length. Interorbital width approximately equal to distance from tip of snout to middle of eye. Anterior narial opening circular, surrounded by short, anteriorly-directed, tubular rim of skin. Opening of anterior nares located along horizontal extending through both tip of snout and maxillary-barbel origin. Distance between anterior nares approximately equal to snout length. Posterior narial opening located on dorsal surface of 


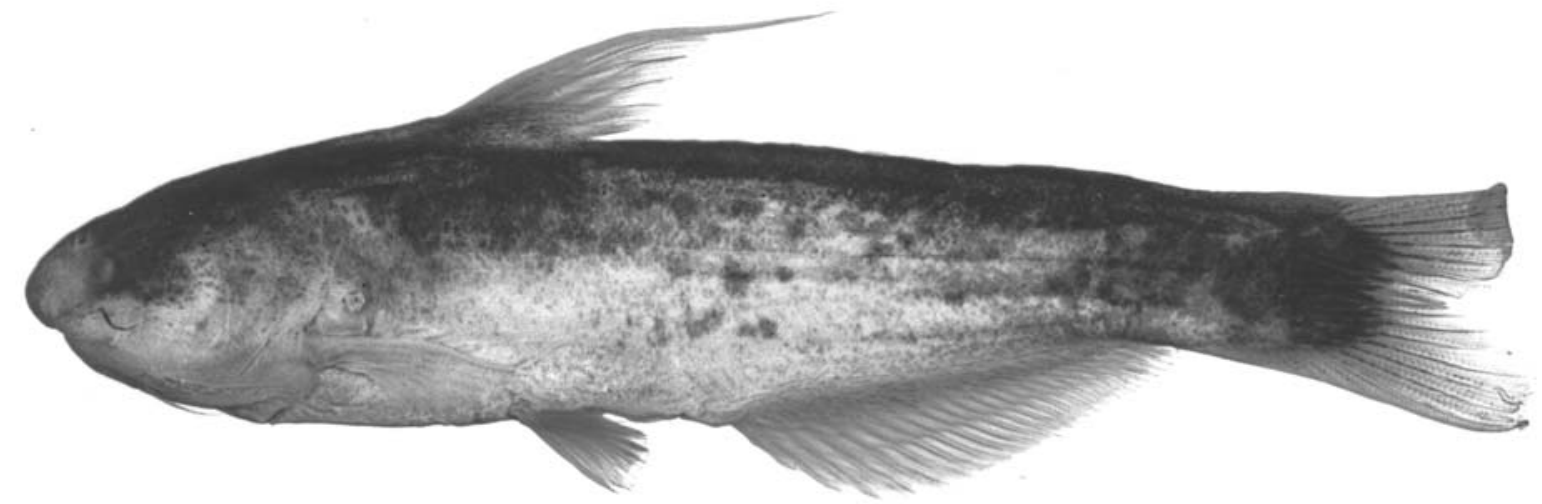

Fig. 43. Cetopsis starnesi, new species, holotype, mature male, USNM 314309, 77 mm SL; Bolivia, Tarija, Argentinean-Bolivian border, río Bermejo, 4-5 km south of Pueblo Salado, approximately 30 air km south of Bermejo (22²7’'S, 64³2’ W).

head, situated along vertical through anterior margin of orbit; narial opening nearly round, with anterior two-thirds of aperture surrounded by flap of skin with anterior portion of flap highest.

Mouth inferior; its width slightly less than one-half of HL. Margin of lower jaw gently rounded, its posterior limit reaching to vertical through posterior margin of orbit. Premaxillary tooth patch in form of gently-arched band, continuous across midline and with anterior margin convex and posterior margin concave and running in parallel to anterior margin. Teeth on premaxilla small, conical, and sharply-pointed, with teeth arranged in three regular rows. Vomerine teeth arranged in single, irregular row continuous across midline. Vomerine teeth stout, conical, and much larger than teeth on premaxilla and dentary. Dentary teeth comparable in shape to, but larger in size than, premaxillary teeth. Dentary dentition consisting of three irregularly-arranged rows medially that taper to one row laterally.

Maxillary barbel slender, its length greater than distance from tip of snout to posterior margin of orbit, but less than one-half of HL; barbel origin located ventral to middle of orbit. Mental barbels approximately equal in length to each other but shorter than maxillary barbel. Medial mental-barbel origin located along vertical through rictus. Lateral mental-barbel origin situated slightly posterior of vertical through origin of medial mental barbel. Tips of adpressed mental barbels falling distinctly short of posterior margin of opercle.

Dorsal fin moderately large overall with length of dorsalfin base approximately $0.39-0.41$ of HL. Length of longest branched dorsal-fin ray equal to two-thirds of HL. Dorsal-fin spinelet absent. First dorsal-fin ray not spinous but with distal filament present in male holotype (condition in female paratype undeterminable because of damage to fin). Distal margin of dorsal fin sinusoidal, with anterior portion concave and posterior portion convex. Dorsal-fin origin located at approximately anterior $0.33-0.35$ of SL and along vertical extending through middle of adpressed pectoral fin. Tip of adpressed dorsal fin, excluding distal filament present on first ray in mature males, reaching nearly to vertical through anal-fin origin. Posterior most dorsal-fin ray without posterior, membra- nous attachment to body.

Caudal fin moderately-forked, symmetrical; tips of lobes apparently pointed. Length of longest caudal-fin ray approximately one and three-fourths times length of middle fin rays.

Base of anal fin moderately long. Anal-fin origin located distinctly posterior of middle of SL. Anal-fin margin straight in female paratype, with posterior most unbranched anal-fin ray longest and subsequent rays becoming gradually shorter. Anal-fin margin distinctly convex in single, examined mature male specimen (holotype). Posterior most anal-fin ray without posterior, membranous attachment to body.

Pelvic fin moderate; distal margin nearly straight, with first ray longest. Pelvic-fin insertion located anterior to middle of SL and along vertical through posterior of base of dorsal fin. Tip of adpressed pelvic fin extending to middle of SL, but falling slightly short of anterior limit of vent. Medial most pelvic-fin ray with membranous attachment to body along basal two-thirds of its length.

Pectoral-fin length approximately two-thirds of HL. Pectoral-fin margin nearly straight laterally and convex medially, with first ray longest and prolonged into distal filament in both sexes, with filament proportionally longer in male holotype than female paratype. First pectoral-fin ray not spinous.

Coloration in alcohol. Overall coloration of head and body in female paratype darker than in male holotype. Dorsal portion of head dark from interorbital region to rear of head. Ventral surface of head pale. Snout pale from tip to posterior nares in male, but somewhat dusky, albeit lighter than remaining dorsal portion of head, in female. Lips pale in male, slightly dusky in female. Dorsal portion of body dark in both sexes. Ground coloration of lateral surface of body pale and overlain by scattered, approximately eye-size, dark spots. Spots more concentrated dorsally and on caudal peduncle. Spots coalesce into irregular blotches, more so in larger specimen female paratype. Ventral surface of body pale.

Dorsal fin in male holotype with semicircular dusky region basally and with dusky interradial membrane between first and second rays and remainder of fin pale. Dark pigmentation on dorsal fin in female paratype more intense but simi- 
lar distribution. Caudal fin with dark, bilobed spot extending from base of branched fin-rays posteriorly approximately to vertical through middle of length of middle fin rays. Middle caudal-fin rays posterior of bilobed spot unpigmented, remaining fin rays in region distal of basal spot dusky. Anal fin of female dusky basally and remainder of fin hyaline. Anal fin of male hyaline throughout. Pectoral and pelvic fins pale.

Barbels dusky on basal one-half of anterior surface but otherwise pale.

Sexual dimorphism. The single examined male of Cetopsis starnesi has the filaments on the pectoral fins proportionally more elongate than are the extensions present in the one examined female of the species. The sexually-dimorphic difference in the degree of the development of the filament on the dorsal fin that is typical of many species in the Cetopsinae cannot be evaluated for $C$. starnesi as a consequence of the damage to the dorsal fin in the single available female (the paratype). The anal-fin margin is distinctly convex in the male in contrast to the straight margin that is present in the female.

Distribution. Cetopsis starnesi is only known from two localities in southeastern Bolivia, the holotype locality (USNM 314309) in the far northwestern portions of the río de La Plata basin and the site where the female paratype (CBF 887) was captured in the far southern reaches of the upper rio Madeira basin (Fig. 41).

Etymology. The species name, starnesi, is in reference, Dr. Wayne C. Starnes, of the North Carolina State Museum of Natural History, who collected the type-series of this species along with numerous other specimens of fishes that have proved very useful in this and other studies.

Remarks. The distribution of Cetopsis starnesi across the divide between the upper rio Madeira of the rio Amazonas basin and the río de La Plata system is uncommon amongst components of the lowland to mid-elevation Neotropical ichthyofauna that have been critically studied to date. Such a distribution across that drainage divide, nonetheless, occurs occasionally in species of various groups that have been studied in recent decades including the freshwater needlefish Potamorrhaphis eigenmanni (Collette, 1982: 738), the cichlids Mesonauta festivus and Astronotus crassipinnis (Kullander, 1986: 37), and the curimatid characiform Psectrogaster curviventris (Vari, 1989a: 31).

Pozzi (1945: 262 and map on page 251) reported Cetopsis caecutiens (=coecutiens) from two localities in northern Argentina, apparently in the río Bermejo basin in the Provinces of Salta and Jujuy. This record by Pozzi was presumably the basis for the later citation of $C$. coecutiens as a component of the Argentinean ichthyofauna by Ringuelet \& Arámburu (1961: 46). Subsequently, Ringuelet et al. (1967: 348) specifically noted that the inclusion of this species in their compendium of the freshwater fishes of Argentina was based on Pozzi (1945) but cited C. coecutiens as being present in the
Provinces of Salta and Catamarca, rather than Salta and Jujuy as indicated by Pozzi (1945). Specimens of the Cetopsinae examined during this study did not include any samples of $C$. coecutiens that originated at any locality within the río de La Plata basin. Furthermore, the only species of the Cetopsinae that we examined that originated in the río Bermejo basin was C. starnesi. In light of the available information we tentatively consider the citations of $C$. coecutiens from northern Argentina by Pozzi (1945), Ringuelet \& Arámburu (1961) and Ringuelet et al. (1967) to refer to C. starnesi.

Castello (1969: 407) reported Pseudocetopsis gobioides from a locality close to the junctions of the río San Antonio and río Bermejo in the Province of Salta, northwestern Argentina. Although Cetopsis gobioides does occur in Argentina in the Provinces of Misiones (MHNG 2389.14), Corrientes (Alonso de Arámburu et al., 1962: 237), and Santa Fe (Oliveros \& Rossi, 1992: 77), all of which are located in the northeastern portions of that country, there are no confirmed records of the occurrence of $C$. gobioides in northwestern Argentina. Neither for that matter are there any records of the latter species from an upland region comparable to that from which the specimens reported by Castello (1969) originated. As noted above the only member of the Cetopsinae known to occur in the río Bermejo basin is Cetopsis starnesi and in light of the available information we consider the report of Pseudocetopsis gobioides from that river system by Castello (1969) to refer to C. starnesi.

Material examined. 2 specimens (77-97 mm SL). Holotype. Bolivia. Tarija: Argentinean-Bolivian border, río Bermejo, 4-5 km S of Pueblo Salado, approximately 30 air km S of Bermejo (22 $27^{\prime} \mathrm{S}$, 64³2’W), W. C. Starnes et al., 5 October 1988, USNM 314309, 1, mature male (77). Paratype. Bolivia. Chuquisaca: río Azero, below road crossing, approximately 35 air km SE of Padilla (19 $37^{\prime} \mathrm{S}$, 640ㄴ'W), W. C. Starnes et al., 28 September 1988, CBF 887, 1, female (97, formerly USNM 314309).

\section{Cetopsis umbrosa, new species}

Figs. 41, 44, Tables 9-15

Diagnosis. Cetopsis umbrosa can be distinguished from all of its congeners by the combination of the presence of an eye, the conical teeth on the vomer and dentary, the rounded posterior nares that is distinctly separated from the contralateral nares by a distance greater than the width of the posterior nares, the absence of a dark humeral spot, the presence of a posteriorly-rounded, variably-developed, bilobed patch of dark pigmentation at the base of the caudal fin, the absence of a spot of dark pigmentation on the base of the dorsal fin and the absence of prominent dark pigmentation along the membrane behind the first ray of the dorsal fin, the presence of approximately eye-size dark spots on the lateral surface of the body, the presence of fine, scattered, dark pigmentation across the lateral and anterior surfaces of snout and the lateral surface of the body. It is further distinguished from the externally somewhat similar C. starnesi in the number of 


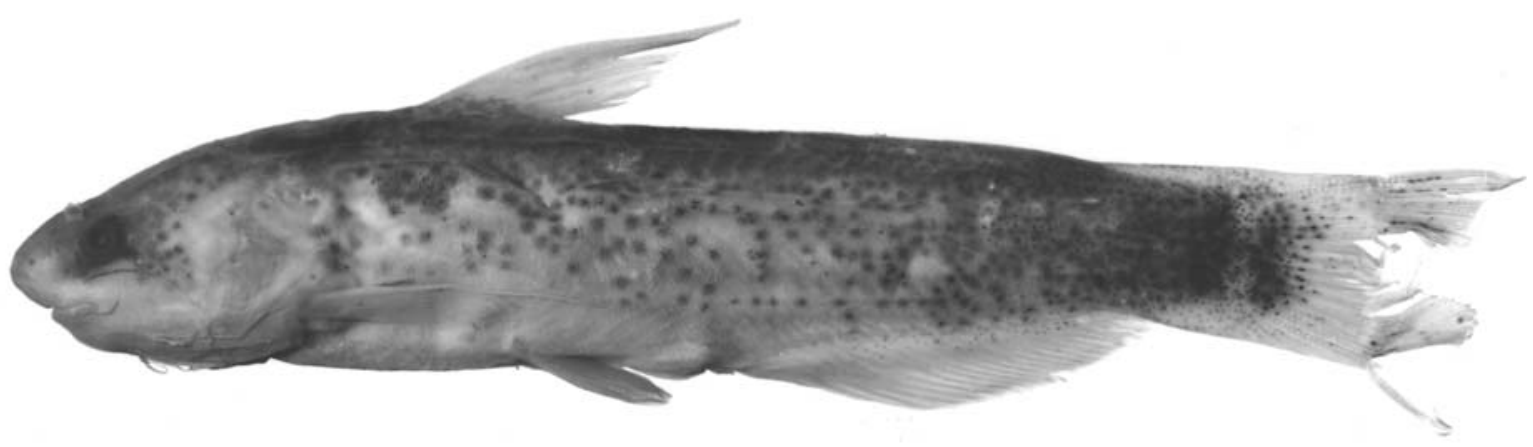

Fig. 44. Cetopsis umbrosa, new species, holotype, ANSP 137559, $54 \mathrm{~mm}$ SL; Colombia, Meta, río Negro, downstream from main Villavicencio-Puerto Lopez highway at La Balsa $\left(04^{\circ} 04^{\prime} \mathrm{N}, 73^{\circ} 04^{\prime} \mathrm{W}\right)$.

precaudal vertebrae (14 versus 11 or 12 , respectively), caudal vertebrae ( 30 versus 33 , respectively), and total anal-fin rays (26 versus 27 or 28 , respectively).

Description. Body moderately-elongate, slightly-compressed anteriorly and becoming progressively distinctly-compressed posteriorly. Body depth at dorsal-fin origin approximately 0.22 of SL, and approximately equal to distance from anterior margin of orbit to posterior margin of opercle. Lateral line on body complete, unbranched, and midlateral, and extending from vertical through pectoral-fin base to hypural plate with short, dorsal bend on hypural plate. Dorsal profile of body nearly straight from nape to dorsal-fin origin and straight from dorsal-fin origin to caudal-fin base. Ventral profile of body slightly convex along abdomen, approximately straight, but posterodorsally-slanted, along base of anal fin. Caudalpeduncle depth slightly greater than caudal-peduncle length.

Head in profile acutely triangular overall. Dorsal profile of head nearly straight from tip of snout to nape. Ventral profile of head slightly convex. Margin of snout in dorsal view distinctly triangular. Postorbital margins of head running nearly in parallel from dorsal view. Enlarged jaw musculature not evident externally on dorsal surface of postorbital portion of head.

Opercular membrane attaching to isthmus only anterior of vertical through pectoral-fin insertion. Opercular opening moderate; extending ventral of pectoral-fin insertion by distance equal to snout length and extending dorsal of pectoralfin insertion by distance slightly less than snout length.

Eye situated on lateral surface of head; located entirely dorsal to horizontal extending through pectoral-fin insertion; eye visible in dorsal view, but not in ventral view, of head. Middle of orbit at approximately anterior one-third of HL. Eye diameter approximately one-half of snout length. Interorbital width approximately equal to snout length. Anterior narial opening circular, surrounded by short, anteriorly-directed, tubular rim of skin. Opening of anterior nares located along horizontal extending through maxillary-barbel origin, but ventral of horizontal running through tip of snout. Distance between anterior nares approximately equal to snout length. Posterior narial opening located on dorsal surface of head, situated along vertical through anterior margin of orbit; narial opening nearly round and with anterior two-thirds surrounded by flap of skin, flap highest anteriorly.

Mouth inferior; its width approximately one-half of HL. Margin of lower jaw rounded, its posterior limit reaching to vertical through posterior margin of orbit. Premaxillary tooth patch in form of gently-arched band, continuous across midline and with anterior margin convex and posterior margin concave and running in parallel to anterior margin. Teeth on premaxilla small, conical, and sharply-pointed, with teeth arranged in three, regular rows. Teeth of inner most row of premaxillary dentition slightly larger than the teeth in other tooth rows. Vomerine teeth arranged in single, irregular row continuous across midline. Vomerine teeth stout, conical, and much larger than teeth on premaxilla or dentary. Dentary teeth comparable in shape to, but larger in size than, premaxillary teeth. Dentary dentition consisting of two regular rows. Teeth of inner tooth row large than those of outer row. Outer tooth row beginning at symphysis, but not extending as far laterally as inner tooth row..

Maxillary barbel slender, its length greater than distance from tip of snout to posterior margins of orbit, but slightly greater than one-half of HL; barbel origin located ventral to middle of orbit. Mental barbels approximately equal in length to each other but shorter than maxillary barbel. Medial mental-barbel origin located along vertical through rictus. Lateral mental-barbel origin situated slightly posterior of vertical through medial mental-barbel origin. Tips of adpressed mental barbels extending to, or slightly beyond, posterior margin of opercle.

Dorsal fin moderately large overall with length of dorsalfin base approximately $0.40-0.43$ of HL. Length of longest branched dorsal-fin ray, excluding distal filament, approximately equal to three-fourths of HL. Dorsal-fin spinelet absent. First dorsal-fin ray not spinous but with distal filament present in single available specimen. Distal margin of dorsal fin nearly straight, with first ray longest. Dorsal-fin origin located at approximately anterior 0.36 of SL and along vertical extending through distal one-fourth of adpressed pectoral fin. Tip of longest branched ray of adpressed dorsal fin, excluding distal filament on first ray, reaching nearly to vertical through vent. Posterior most dorsal-fin ray without posterior, membranous attachment to body. 
Table 9. Number of specimens of the species of Cetopsis with cited number of dorsal- and pectoral-fin rays. Bold indicates value for holotype or lectotype when examined. Dorsal fin of C. jurubidae damaged and count of rays uncertain; 6 branched dorsal-fin rays cited for holotype of species by Fowler (1944:235).

\begin{tabular}{|c|c|c|c|c|c|c|c|}
\hline & \multicolumn{3}{|c|}{ Dorsal-fin Rays } & \multicolumn{4}{|c|}{ Pectoral-fin Rays } \\
\hline & 5 & 6 & 7 & 7 & 8 & 9 & 10 \\
\hline C. amphiloxa & & 7 & & & 6 & 1 & \\
\hline C. arcana & & 10 & & & 6 & & \\
\hline C. baudoensis & & 14 & & & & 13 & 1 \\
\hline C. caiapo & & 1 & & & 1 & & \\
\hline C. candiru & 4 & 29 & & & 27 & & \\
\hline C. coecutiens & & 102 & & & & 85 & 1 \\
\hline C. fimbriata & & 27 & & & 2 & 25 & \\
\hline C. gobioides & 1 & 32 & 1 & 2 & 26 & 6 & \\
\hline C. jurubidae & & 1 & & & & 1 & \\
\hline C. montana & & 23 & & & 16 & 4 & \\
\hline C. motatanensis & & 8 & & & 1 & 7 & \\
\hline C. oliveirai & & 15 & & & 15 & & \\
\hline C. orinoco & & 68 & & & 57 & 8 & \\
\hline C. othonops & & 33 & & & 18 & 5 & \\
\hline C. parma & & 4 & & & 2 & 1 & \\
\hline C. pearsoni & 1 & 5 & 1 & & 7 & & \\
\hline C. plumbea & & 61 & 1 & & 53 & 8 & 1 \\
\hline C. sandrae & & 6 & & & 6 & & \\
\hline C. sarcodes & & 1 & & & & 1 & \\
\hline C. starnesi & & 2 & & & 2 & & \\
\hline C. umbrosa & & 1 & & & 1 & & \\
\hline
\end{tabular}

Table 10. Number of specimens of the species of Cetopsis with cited number of branched anal-fin rays. Bold indicates value for holotype or lectotype when examined. Cetopsis oliveirai lacks branched anal-fin rays.

\begin{tabular}{|c|c|c|c|c|c|c|c|c|c|c|c|c|c|}
\hline & & & & & Bra & iche & $\mathrm{An}$ & al-fir & Ray & & & & \\
\hline & 17 & 18 & 19 & 20 & 21 & 22 & 23 & 24 & 25 & 26 & 27 & 28 & 29 \\
\hline C. amphiloxa & & & & & & & 1 & - & - & 2 & 1 & 1 & \\
\hline C. arcana & & 1 & 2 & 5 & 1 & 1 & & & & & & & \\
\hline C. baudoensis & & & & 6 & 7 & 1 & & & & & & & \\
\hline C. caiapo & & 1 & & & & & & & & & & & \\
\hline C. candiru & & & & & & & & 1 & 1 & 5 & 2 & 3 & 1 \\
\hline C. coecutiens & & 9 & 39 & 35 & 9 & & & & & & & & \\
\hline C. fimbriata & & & & 3 & 9 & 7 & & & & & & & \\
\hline C. gobioides & 2 & 7 & 3 & 10 & 9 & 3 & & & & & & & \\
\hline C. jurubidae & & & & & & & 1 & & & & & & \\
\hline C. montana & & & 3 & 5 & 6 & & & & & & & & \\
\hline C. motatanensis & & & & & 3 & 3 & 2 & & & & & & \\
\hline C. oliveirai & & & - & - & - & - & - & & & & & & \\
\hline C. orinoco & & & 1 & 2 & 19 & 16 & 8 & 2 & & & & & \\
\hline C. othonops & & & & 13 & 13 & 7 & 2 & & & & & & \\
\hline C. parma & & 1 & - & 2 & & & & & & & & & \\
\hline C. pearsoni & & & & 2 & 5 & & & & & & & & \\
\hline C. plumbea & & & & 1 & 1 & 8 & 13 & 18 & 9 & 3 & & & \\
\hline C. sandrae & & 1 & 3 & 2 & & & & & & & & & \\
\hline C. sarcodes & & & & & 1 & & & & & & & & \\
\hline C. starnesi & & & & & & 1 & 1 & & & & & & \\
\hline C. umbrosa & & & & & 1 & & & & & & & & \\
\hline
\end{tabular}

Caudal fin forked, apparently symmetrical; tips of lobes damaged in single available specimen.

Base of anal fin moderately long. Anal-fin origin located well posterior of middle of SL, and approximately along vertical through middle of TL. Anal-fin margin slightly convex in single available specimen, an apparently mature male. Poste- rior most anal-fin ray without posterior, membranous attachment to body.

Pelvic fin moderate; distal margin nearly straight, with first ray longest. Pelvic-fin insertion located anterior to middle of SL and along vertical through posterior portion of base of dorsal fin. Tip of adpressed pelvic fin extending beyond middle of SL and falling short of anterior limit of vent. Medial most pelvic-fin ray with membranous attachment to body along basal two-thirds of its length.

Pectoral-fin length approximately two-thirds of HL. First pectoral-fin ray not spinous, but with first ray longest and prolonged into distal filament. Pectoral-fin margin sinusoidal, concave laterally and convex medially.

Coloration in alcohol. Scattered, dark pigmentation covering dorsal portion of head from tip of snout to rear of head. Interorbital region slightly darker than adjoining areas. Areas posteroventral and posterior of orbit with patch of distinct, large, dark chromatophores. Opercular region and ventral portions of head lack distinct, dark chromatophores. Dorsal portion of body dark. Lateral surface of body with scattered, very small, superficial, dark chromatophores and with scattered, deep-lying, dark spots smaller than size of pupil. Spots rarely coalesce into larger spots other than on posterior portion of caudal peduncle. Caudal peduncle with numerous dark spots. Ventral and ventrolateral surface of abdomen pale.

Dorsal fin pale, with some indication of dusky basal region; fin membranes otherwise hyaline. Caudal fin largely pale but with dark, bilobed spot extending from base of branched fin-rays posteriorly approximately to vertical through middle of length of inner most rays. Anal fin pale other than for some scattered, dark, superficial chromatophores on basal portion of fin. Pectoral and pelvic fins pale.

Barbels dusky on basal portion of anterior surface but otherwise pale.

Sexual dimorphism. The holotype, the only available specimen of Cetopsis umbrosa, is presumed to be a mature male in light of its possession of distal filaments on the first rays of the dorsal and pectoral fins and the presence of a convex margin of the anal fin. These features are typical of mature males of many other species in the Cetopsinae.

Distribution. Cetopsis umbrosa is known only from a single locality in the western portions of the río Orinoco basin (Fig. 41).

Remarks. Although Cetopsis umbrosa is known from only one specimen, the combination of characters noted in the "Diagnosis" serves to distinguish if from all congeners. It is most similar overall to $C$. starnesi, a species that also has a bilobed dark spot at the base of the caudal fin, but whose distributional range in southern Bolivia is geographically distant from the location within Colombia where the holotype of 
Table 11. Number of specimens of the species of Cetopsis with cited number of total anal-fin rays. Bold indicates value for holotype or lectotype when examined.

\begin{tabular}{|c|c|c|c|c|c|c|c|c|c|c|c|c|c|c|c|c|c|c|c|}
\hline & \multicolumn{19}{|c|}{ Total Anal-fin Rays } \\
\hline & 17 & 18 & 19 & 20 & 21 & 22 & 23 & 24 & 25 & 26 & 27 & 28 & 29 & 30 & 31 & 32 & 33 & 34 & 35 \\
\hline C. amphiloxa & & & & & & & & & & & & & 2 & 2 & 1 & 1 & 1 & & \\
\hline C. arcana & & & & & & & 1 & 2 & 4 & 2 & - & 1 & & & & & & & \\
\hline C. baudoensis & & & & & & & 1 & - & 6 & 5 & 2 & & & & & & & & \\
\hline C. caiapo & & & & & & 1 & & & & & & & & & & & & & \\
\hline C. candiru & & & & & & & & & & & & 1 & 2 & 8 & 13 & 7 & 2 & 3 & 1 \\
\hline C. coecutiens & & & & & & 2 & 17 & 49 & 26 & 5 & & & & & & & & & \\
\hline C. fimbriata & & & & & & & & & 2 & 6 & 8 & 3 & & & & & & & \\
\hline C. gobioides & & & & & & 1 & 6 & 10 & 7 & 6 & 4 & & & & & & & & \\
\hline C. jurubidae & & & & & & & & & & & & 1 & & & & & & & \\
\hline C. montana & & & & & & & 1 & 2 & 11 & 7 & 1 & 1 & & & & & & & \\
\hline C. motatanensis & & & & & & & & & & 1 & 5 & 1 & 1 & & & & & & \\
\hline C. oliveirai & 4 & 8 & 3 & & & & & & & & & & & & & & & & \\
\hline C. orinoco & & & & & & & 1 & 2 & 6 & 14 & 27 & 9 & 7 & 1 & & & & & \\
\hline C. othonops & & & & & & & 1 & 4 & 10 & 14 & 7 & 1 & & & & & & & \\
\hline C. parma & & & & & & & 1 & - & 2 & & & & & & & & & & \\
\hline C. pearsoni & & & & & & & & & 3 & 3 & & & & & & & & & \\
\hline C. plumbea & & & & & & & & & & 2 & 4 & 17 & 18 & 15 & 4 & & & & \\
\hline C. sandrae & & & & & & & 3 & 3 & & & & & & & & & & & \\
\hline C. sarcodes & & & & & & & & & 1 & & & & & & & & & & \\
\hline C. starnesi & & & & & & & & & & & 1 & 1 & & & & & & & \\
\hline C. umbrosa & & & & & & & & & & 1 & & & & & & & & & \\
\hline
\end{tabular}

Table 12. Number of specimens of the species of Cetopsis with cited number of preanal vertebrae. Bold indicates value for holotype or lectotype when examined.

\begin{tabular}{|c|c|c|c|c|c|c|c|c|c|c|c|c|}
\hline & & & & & Prea & inal & verte & orae & & & & \\
\hline & 14 & 15 & 16 & 17 & 18 & 19 & 20 & 21 & 22 & 23 & 24 & 25 \\
\hline C. amphiloxa & 3 & 1 & 3 & & & & & & & & & \\
\hline C. arcana & & 1 & 7 & 2 & & & & & & & & \\
\hline C. baudoensis & & & & & 5 & 7 & 2 & & & & & \\
\hline C. caiapo & & & & & & 1 & & & & & & \\
\hline C. candiru & & & & & & & & 3 & 6 & 21 & 5 & 4 \\
\hline C. coecutiens & & & & & & 1 & 19 & 50 & 23 & 3 & 1 & \\
\hline C. fimbriata & & 1 & 1 & 4 & 11 & 2 & & & & & & \\
\hline C. gobioides & & & 12 & 15 & 6 & & & & & & & \\
\hline C. jurubidae & & & & & 1 & & & & & & & \\
\hline C. montana & & & 7 & 10 & & & & & & & & \\
\hline C. motatanensis & & & & & 2 & 5 & 1 & & & & & \\
\hline C. oliveirai & & & & 6 & 6 & 2 & & & & & & \\
\hline C. orinoco & & 3 & 24 & 28 & 5 & 2 & & & & & & \\
\hline C. othonops & & & 1 & 11 & 18 & 6 & & & & & & \\
\hline C. parma & & & 1 & - & 1 & - & 1 & & & & & \\
\hline C. pearsoni & & 2 & 4 & 1 & & & & & & & & \\
\hline C. plumbea & & 8 & 12 & 17 & 11 & 3 & & & & & & \\
\hline C. sandrae & 1 & 2 & 2 & 1 & & & & & & & & \\
\hline C. sarcodes & & & & & & 1 & & & & & & \\
\hline C. starnesi & & & 1 & 1 & & & & & & & & \\
\hline C. umbrosa & & & & 1 & & & & & & & & \\
\hline
\end{tabular}

C. umbrosa was collected. Furthermore, those two species differ in a number of features, most notably in the number of precaudal and caudal vertebrae (see Tables 13, 14). Additional specimens of each species are necessary to determine whether the apparent difference in the number of total analfin rays in the two species (Table 11) also serves to distinguish the two nominal forms.
Table 13. Number of specimens of the species of Cetopsis with cited number of precaudal vertebrae. Bold indicates values for holotype or lectotype when examined.

\begin{tabular}{|c|c|c|c|c|c|c|c|c|c|}
\hline & \multicolumn{9}{|c|}{ Precaudal Vertebrae } \\
\hline & 10 & 11 & 12 & 13 & 14 & 15 & 16 & 17 & 18 \\
\hline C. amphiloxa & 2 & 4 & 1 & & & & & & \\
\hline C. arcana & & 1 & 3 & 6 & & & & & \\
\hline C. baudoensis & & & & & 8 & 5 & 1 & & \\
\hline C. caiapo & & & & & & 1 & & & \\
\hline C. candiru & & & & & 2 & 15 & 14 & 7 & 1 \\
\hline C. coecutiens & & & 2 & 23 & 46 & 26 & 3 & & \\
\hline C. fimbriata & & & 1 & 3 & 10 & 5 & & & \\
\hline C. gobioides & & 4 & 10 & 11 & 7 & 1 & & & \\
\hline C. jurubidae & & & 1 & & & & & & \\
\hline C. montana & & & 1 & 15 & 4 & & & & \\
\hline C. motatanensis & & & & & & 7 & - & 1 & \\
\hline C. oliveirai & & & & 2 & 10 & 3 & & & \\
\hline C. orinoco & & 3 & 18 & 31 & 12 & 3 & & & \\
\hline C. othonops & & & & 7 & 23 & 6 & & & \\
\hline C. parma & & & & & & 2 & 1 & & \\
\hline C. pearsoni & & & & 5 & 2 & & & & \\
\hline C. plumbea & 2 & 16 & 24 & 12 & 5 & & & & \\
\hline C. sandrae & & 1 & 4 & 1 & & & & & \\
\hline C. sarcodes & & & & & & 1 & & & \\
\hline C. starnesi & & 1 & 1 & & & & & & \\
\hline C. umbrosa & & & & & 1 & & & & \\
\hline
\end{tabular}

One specimen from a locality rather distant from the known distribution of Cetopsis umbrosa (INPA 8485) either represents this species or a closely related, albeit perhaps undescribed, form (see comments under "Remarks" for $C$. montana). 
Table 14. Number of specimens of the species of Cetopsis with cited number of caudal vertebrae. Bold indicates value for holotype or lectotype when examined.

\begin{tabular}{|c|c|c|c|c|c|c|c|c|c|c|c|c|c|c|c|c|}
\hline & \multicolumn{16}{|c|}{ Caudal Vertebrae } \\
\hline & 25 & 26 & 27 & 28 & 29 & 30 & 31 & 32 & 33 & 34 & 35 & 36 & 37 & 38 & 39 & 40 \\
\hline C. amphiloxa & & & & & & & 5 & 1 & 1 & & & & & & & \\
\hline C. arcana & & & & 1 & 3 & 2 & 4 & & & & & & & & & \\
\hline C. baudoensis & & & & & & & & & 3 & 7 & 2 & & & & & \\
\hline C. caiapo & & & & & 1 & & & & & & & & & & & \\
\hline C. candiru & & & & & & & & & & 1 & 3 & 11 & 10 & 10 & 1 & 2 \\
\hline C. coecutiens & & & & & & & & 2 & 6 & 28 & 36 & 26 & 2 & & & \\
\hline C. fimbriata & & & & & & & 1 & 5 & 6 & 6 & 1 & & & & & \\
\hline C. gobioides & & & & & 6 & 5 & 12 & 7 & 3 & & & & & & & \\
\hline C. jurubidae & & & & & & & 1 & & & & & & & & & \\
\hline C. montana & & & & & 3 & 9 & 9 & - & 1 & & & & & & & \\
\hline C. motatanensis & & & & & & & & & 2 & 4 & 2 & & & & & \\
\hline C. oliveirai & 10 & 5 & & & & & & & & & & & & & & \\
\hline C. orinoco & & & & & & 10 & 18 & 21 & 17 & - & 1 & & & & & \\
\hline C. othonops & & & & & & 2 & 10 & 15 & 7 & 2 & & & & & & \\
\hline C. parma & & & & & 3 & & & & & & & & & & & \\
\hline C. pearsoni & & & & & 2 & 3 & 2 & & & & & & & & & \\
\hline C. plumbea & & & & & & & & 1 & 8 & 13 & 19 & 11 & 5 & 2 & & \\
\hline C. sandrae & & & & 4 & 2 & & & & & & & & & & & \\
\hline C. sarcodes & & & & 1 & & & & & & & & & & & & \\
\hline C. starnesi & & & & & & & & & 2 & & & & & & & \\
\hline C. umbrosa & & & & & & 1 & & & & & & & & & & \\
\hline
\end{tabular}

Table 15. Number of specimens of the species of Cetopsis with cited number of total vertebrae. Bold indicates value for holotype or lectotype when examined.

\begin{tabular}{|c|c|c|c|c|c|c|c|c|c|c|c|c|c|c|c|c|}
\hline & \multicolumn{16}{|c|}{ Total Vertebrae } \\
\hline & 39 & 40 & 41 & 42 & 43 & 44 & 45 & 46 & 47 & 48 & 49 & 50 & 51 & 52 & 53 & 54 \\
\hline C. amphiloxa & & & 1 & 3 & 3 & & & & & & & & & & & \\
\hline C. arcana & & & 1 & 4 & 5 & & & & & & & & & & & \\
\hline C. baudoensis & & & & & & & & & 2 & 5 & 5 & & & & & \\
\hline C. caiapo & & & & & & 1 & & & & & & & & & & \\
\hline C. candiru & & & & & & & & & & & 1 & 1 & 5 & 4 & 18 & 9 \\
\hline C. coecutiens & & & & & & & & & 3 & 25 & 52 & 20 & & & & \\
\hline C. fimbriata & & & & & & & & 3 & 12 & 4 & & & & & & \\
\hline C. gobioides & & & & 2 & 12 & 17 & 3 & & & & & & & & & \\
\hline C. jurubidae & & & & & 1 & & & & & & & & & & & \\
\hline C. montana & & & & 1 & 9 & 10 & & & & & & & & & & \\
\hline C. motatanensis & & & & & & & & & & 1 & 4 & 3 & & & & \\
\hline C. oliveirai & 9 & 6 & & & & & & & & & & & & & & \\
\hline C. orinoco & & & & & 3 & 26 & 30 & 8 & & & & & & & & \\
\hline C. othonops & & & & & & & 10 & 21 & 4 & 1 & & & & & & \\
\hline C. parma & & & & & & 2 & 1 & & & & & & & & & \\
\hline C. pearsoni & & & & & 5 & 2 & & & & & & & & & & \\
\hline C. plumbea & & & & & & & 3 & 21 & 15 & 13 & 6 & 1 & & & & \\
\hline C. sandrae & & 4 & 2 & & & & & & & & & & & & & \\
\hline C. sarcodes & & & & & 1 & & & & & & & & & & & \\
\hline C. starnesi & & & & & & 1 & 1 & & & & & & & & & \\
\hline C. umbrosa & & & & & & 1 & & & & & & & & & & \\
\hline
\end{tabular}

Etymology. The specific name, umbrosa, from the Latin for shady refers to the presence of pigmentation on the dorsal and anterior portions of the snout. This pigmentation pattern contrasts with the unpigmented snout characteristic of the geographically-proximate and somewhat externally similar $C$. montana.
Material examined. 1 specimen (54 mm SL). Holotype. Colombia. Meta: río Negro, downstream from main Villavicencio to Puerto Lopez highway at La Balsa $\left(04^{\circ} 04^{\prime} \mathrm{N}, 73^{\circ} 04^{\prime} \mathrm{W}\right)$, J. E. Böhlke et al., 29 February 1972, ANSP 137559, 1 (54). 


\section{Genus Denticetopsis Ferraris, 1996}

\section{Denticetopsis Ferraris, 1996: 162 [type species: Denticetopsis sauli Ferraris, 1996, by original designation].}

Diagnosis. Denticetopsis can be differentiated from all other members of the Cetopsinae by the following features. The caudal-fin margin is either shallowly-forked or obliquely-truncate with the outer most rays no more than one and one-half times the length of the inner most rays (versus one and threequarters to two times that length in other genera of the Cetopsinae). The medial most pelvic-fin ray has a membranous attachment to the body for the basal one-third to onefourth of its length (versus an attachment more typically along the basal one-half of the ray, respectively). The possession of a first pectoral-fin ray that is spinous for the basal one-half of its length further separates Denticetopsis from Cetopsis and Paracetopsis both of which lack a spinous first pectoralfin ray. Denticetopsis is further distinguished from Cetopsidium in the lack of the dorsal-spine locking mechanism that is present in the latter genus and in the having a lateral line extending either only onto the abdomen or distinctly further posteriorly onto the caudal peduncle (versus terminating above the base of the anal fin, receptively).

Remarks. The original concept of Denticetopsis by Ferraris (1996: 162) was restricted to two species, D. royeroi and D. sauli that have proved to be a subunit of a larger clade (unpublished results) that also includes two species previously assigned to Pseudocetopsis (D. macilenta, D. praecox) together with three species described as new in this publication (D. epa, D. iwokrama, D. seducta).

A single specimen of Denticetopsis in poor condition from an unspecified locality in the rio Gurupi basin, State of Maranhão, northeastern Brazil (MZUSP 42444, formerly MPEG 2660) does not fit the diagnosis of any of the species of Denticetopsis recognized in this study. In addition this sample represents the only record of Denticetopsis from the rivers of Northeastern Brazil. This specimen may very well represent another undescribed species of Denticetopsis given several differences between that individual and other examined samples of the genus, in addition to the geographic separation of rio Gurupi basin from the known ranges of the other species of Denticetopsis recognized in this study. We defer further action on the question of the identity of this specimen until such time as more extensive series of recently collected specimens of Denticetopsis from the rio Gurupi become available.

\section{Denticetopsis epa, new species}

Figs. 45-46, Tables 16-22

Diagnosis. Denticetopsis epa can be differentiated from $D$. royeroi and $D$. sauli by the combination of the lack of elon- gate, symphyseal teeth on the dentary, the lateral line extending posteriorly on the body beyond the abdomen at least onto the caudal peduncle, the presence of dentition on the vomer, a dorsal fin with 5 or 6 segmented rays and a first ray that is spinous basally, a symmetrical, shallowlyforked caudal fin, and the possession of horizontally-elongate, stellate, dark chromatophores on the body when the chromatophores are expanded. Denticetopsis epa differs from D. macilenta in the relative length of the pelvic fin (tip of the pelvic fin reaching to the posterior margin of the vent versus falling just short of the anterior margin of the vent, respectively), in the relative position of the eye (anterior limit of eye located at, or posterior of, the vertical through the anterior limit of the maxillary-barbel groove versus middle of the eye located at the vertical through the anterior limit of the maxillary-barbel groove, respectively). Denticetopsis epa differs from $D$. praecox in the relative length of the pelvic fin (reaching to the posterior margin of the vent versus falling just short of the anterior margin of the vent, respectively) and in the number of premaxillary tooth rows (three rows of teeth on premaxilla in all but smallest examined specimens versus two rows of teeth, respectively). Denticetopsis epa differs from D. iwokrama in the number of total anal-fin rays (25 to 27 versus 29 , respectively) and in the number of caudal ( 26 to 28 versus 32, respectively), preanal (14 or 15 versus 17, respectively), and total vertebrae (38 to 40 versus 43 , respectively). Denticetopsis epa differs from D. seducta in the relative position of the origin of the anal fin (approximately at the vertical through the middle of TL versus distinctly anterior of that point, respectively) and in the relative depth of the caudal peduncle relative to the length of the caudal peduncle (depth/length 1.15-1.3 versus $1.33-1.5$, respectively).

Description. Body moderately-elongate, slightly-compressed laterally anteriorly and becoming progressively distinctlycompressed posteriorly. Body depth at dorsal-fin origin approximately 0.25 of SL, and approximately equal to distance from anterior margin of eye to posterior margin of opercle. Lateral line on body complete, unbranched, and midlateral; extending from vertical through pectoral-fin base onto caudal peduncle but falling to varying degrees short of posterior margin of hypural plate. Dorsal profile of body nearly straight from nape to dorsal-fin origin and nearly straight from dorsalfin origin to caudal-fin base. Ventral profile of body convex along abdomen, approximately straight, but posterodorsallyslanted, along base of anal fin. Caudal-peduncle depth approximately 1.5 times caudal-peduncle length.

Head in profile acutely triangular overall with bluntlypointed snout. Dorsal profile of head slightly convex from tip of snout to nape. Ventral profile of head slightly convex. Margin of snout in dorsal view ranging from rounded to bluntly triangular. Postorbital margins of head running nearly in parallel from dorsal view. Enlarged jaw musculature very evident externally on dorsal surface of postorbital portion of head. 


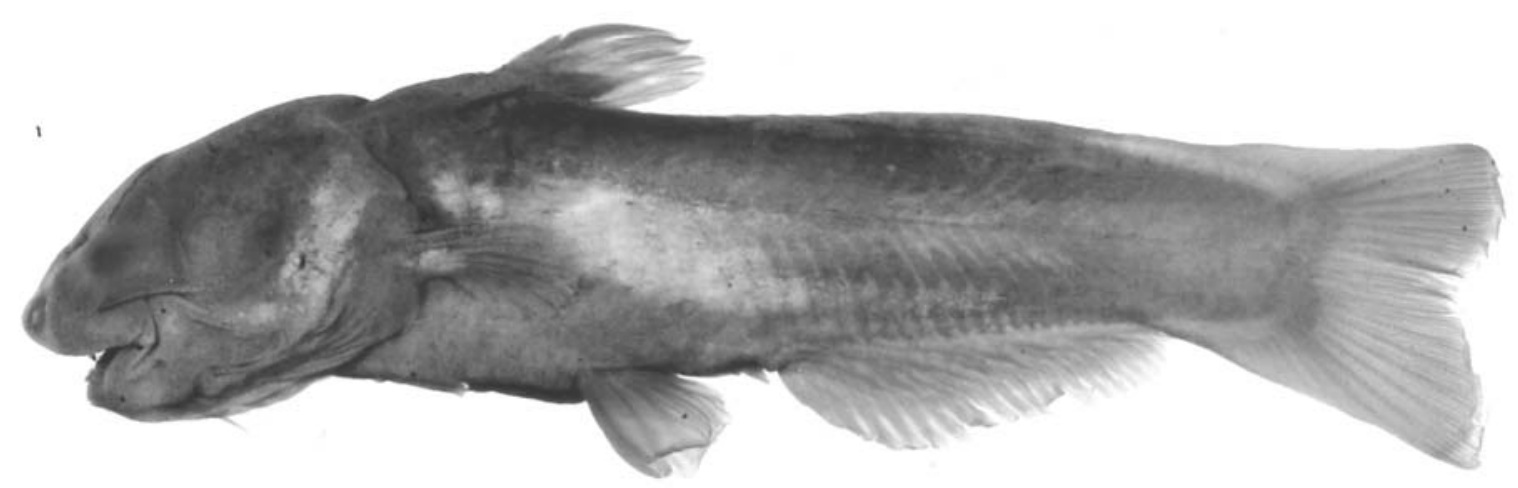

Fig. 45. Denticetopsis epa, new species, holotype, MZUSP 24060, 47 mm SL; Brazil, Pará, Igarapé do Limão, rio Tocantins, Baião (2॰41's, $\left.49^{\circ} 41^{\prime} \mathrm{W}\right)$.

Opercular membrane attaching to isthmus only anterior of vertical through pectoral-fin insertion. Opercular opening moderate; extending ventral of pectoral-fin insertion by distance equal to distance from tip of snout to posterior margin of eye and extending dorsal of pectoral-fin insertion by distance equal to diameter of eye.

Eye situated on lateral surface of head; located entirely dorsal to horizontal extending through pectoral-fin insertion; eye visible in dorsal view, but not in ventral view, of head. Middle of orbit at approximately anterior one-third of HL. Eye diameter approximately one-third of snout length. Interorbital width slightly greater than distance from tip of snout to posterior margin of orbit. Anterior narial opening circular, surrounded by short, anteriorly-directed, tubular rim of skin. Opening of anterior nares located along horizontal extending through maxillary-barbel origin and ventral of horizontal extending through tip of snout. Distance between anterior nares approximately equal to distance from tip of snout to middle of eye. Posterior narial opening located on dorsal surface of head, situated along vertical through anterior margin of orbit; narial opening rounded and completely surrounded by flap of skin of nearly uniform height and with posterior margins of flap in contact.

Mouth inferior; its width approximately one-half of HL. Margin of lower jaw gently rounded, its posterior limit reaching to vertical through posterior margin of orbit. Premaxillary tooth patch in form of gently-arched band, continuous across midline, with anterior margin convex and posterior margin concave and running in parallel to anterior margin. Teeth on premaxilla small, conical, and sharply-pointed, with teeth arranged in two regular rows of uniform-sized teeth, and with variable number of teeth situated anterior of those two series that sometimes form irregular, third row. Vomerine teeth arranged in single, arched row with small gap in series at midline. Vomerine teeth stout and conical, becoming progressively larger laterally, with even smallest teeth on vomer larger than teeth on premaxilla. Dentary teeth comparable in shape to, but larger in size than, premaxillary teeth. Dentary dentition consisting of three, irregular row medially that taper to one row laterally.

Maxillary barbel slender, its length approximately equal to distance from tip of snout to rear of eye, and approximately one-third of HL; barbel origin located ventral to middle of orbit. Medial mental barbel slightly shorter than lateral mental barbel, with latter approximately equal in length to maxillary barbel. Medial mental-barbel origin located along vertical through rictus. Lateral mental-barbel origin situated slightly posterior of vertical through medial mental-barbel origin. Tips of adpressed mental barbel falling short of posterior margin of opercle.

Dorsal fin moderately large overall with length of dorsalfin base approximately $0.29-0.31$ of HL. Length of longest branched dorsal-fin ray equal to approximately one-half of HL. Dorsal-fin spinelet absent. First dorsal-fin ray spinous for basal one-half of length but flexible more distally; without distal filament present in some species of the Cetopsinae. Distal margin of dorsal fin convex, with second branched ray longest. Dorsal-fin origin located at approximately anterior $0.25-0.27$ of SL and situated along vertical extending through middle of adpressed pectoral fin. Tip of adpressed dorsal fin reaching vertical through vent. Posterior most dorsal-fin ray without posterior, membranous attachment to body.

Caudal fin shallowly-forked, symmetrical; tips of lobes rounded. Length of longest caudal-fin ray approximately 1.5 times length of middle fin rays.

Base of anal fin moderately long. Anal-fin origin located distinctly posterior of middle of SL and approximately at middle of TL. Anal-fin margin slightly convex in all examined specimens. Membranous attachment present between posterior margin of basal one-half of posterior most anal-fin ray and caudal peduncle.

Pelvic fin moderately long; distal margin slightly convex, with middle fin rays longest. Pelvic-fin insertion located anterior to middle of SL and along vertical through posterior terminus of base of dorsal-fin. Tip of adpressed pelvic fin extending past middle of SL, and reaching posterior margin of vent. Medial most pelvic-fin ray with membranous attachment to body along basal one-fourth of its length.

Pectoral-fin length approximately one-half of HL. Pectoral-fin margin distinctly convex, with middle ray longest. First pectoral-fin ray spinous with smooth margins and proportionally short, with length approximately one-half that of first branched fin ray. 


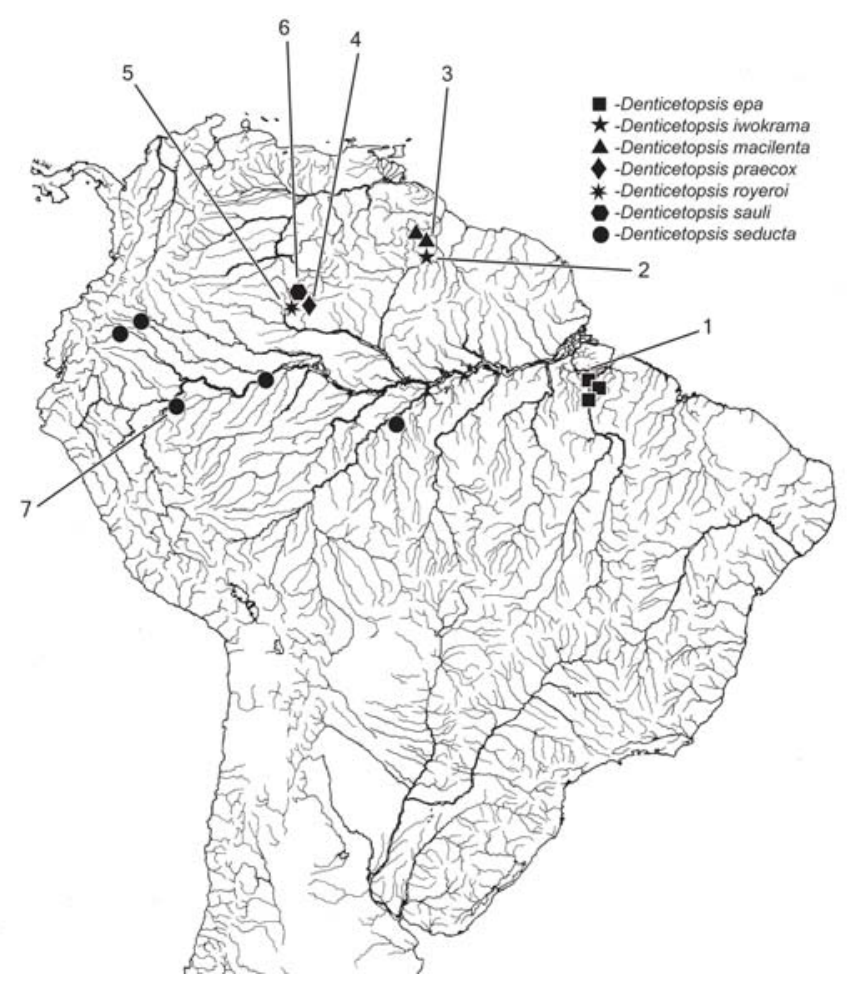

Fig. 46. Map of central and northern South America showing geographic distribution of Denticetopsis epa $(1=$ holotype locality), Denticetopsis iwokrama ( 2 = holotype locality), Denticetopsis macilenta $(3=$ holotype locality of Hemicetopsis macilenta), Denticetopsis praecox $(4=$ holotype locality), Denticetopsis royeroi $(5=$ holotype locality), Denticetopsis sauli ( 6 = holotype locality), and Denticetopsis seducta $(7$ = holotype locality) (some symbols represent more that one locality and/or lot of specimens).

Coloration in alcohol. Available specimens apparently largely depigmented. Body in most intensely pigmented specimens with lateral and dorsal surfaces covered with diffuse, horizontally-elongate, dark spots when chromatophores expanded; horizontally-elongate chromatophores supplemented by some scattered, smaller, more-darkly pigmented spots. Less darkly-pigmented specimens with widely-scattered, small, dark spots on body; spots occasionally very few in number. Head with diffuse, dark pigmentation scattered over dorsal and lateral surfaces. Less intensely-pigmented specimens with proportionally fewer chromatophores on head. Abdomen and ventral surface of head pale.

Dorsal fin dusky basally and pale distally. Anal, caudal, pelvic, and pectoral fins pale to very slightly dusky.

Barbels with scattered, dark pigmentation basally and pale distally.

Sexual dimorphism. The examined specimens of Denticetopsis epa lack the sexually-dimorphic features of the dorsal, pectoral, and anal fins that are characteristic of many species in the Cetopsinae, albeit not the other species of Denticetopsis.
Distribution. Denticetopsis epa is known from several localities in the lower portions of the rio Tocantins basin (Fig. 46).

Etymology. The species name, epa, is in reference to the Brazilian Expedição Permanente de Amazônia, commonly cited as EPA, which collected large series of scientifically valuable fishes across broad expanses of the Amazon basin and that collected the type series of Denticetopsis epa. It is treated as a noun in apposition.

Material examined. 20 specimens (20, 18-47 mm SL). Holotype. Brazil. Pará: Igarapé do Limão, rio Tocantins, Baião $\left(2^{\circ} 41^{\prime}\right.$ 'S, 4941'W), Expedição Permanente de Amazônia (EPA), 9 September 1970, MZUSP 24060, 1 (47). Paratypes. 19 specimens (19, 18-44 mm SL). Brazil. Pará: Igarapé do Limão, rio Tocantins, Baião ( $2^{\circ} 41^{\prime}$ S , 4941'W), Expedição Permanente de Amazônia (EPA), 9 September 1970, MZUSP 83228, 7 (27-44, 4 specimens, 27-44 mm, cleared and stained); USNM 372767, 2 (30-37). Igarapé \# 5, $\mathrm{km} 5$ on road from Tucuruí to Mato Grosso, Expedição Permanente de Amazônia (EPA), MZUSP 24183, 7 (18-31; 2 specimens, 34-35 $\mathrm{mm}$, cleared and stained). Igarapé Pacuí, at km 97 on highway between Belém and Brasília (1³6’S, 47¹3'W), MZUSP 22279, 3 (30-37.5).

\section{Denticetopsis iwokrama, new species Figs. 46-47, Tables 16-22}

Diagnosis. Denticetopsis iwokrama can be differentiated from $D$. royeroi and $D$. sauli by the combination of the lack of elongate, symphyseal teeth on the dentary, the possession of a lateral line extending posteriorly beyond the abdomen at least onto the caudal peduncle, the presence of dentition on the vomer, a dorsal fin with 5 or 6 rays and with the first ray that is spinous basally, the symmetrical, shallowly-forked caudal fin, and the possession of horizontally-elongate, stellate, dark chromatophores when the chromatophores are expanded. Denticetopsis iwokrama differs from D. epa in the number of caudal (32 versus 26 to 28, respectively), preanal (17 versus 14 or 15, respectively), and total vertebrae (43 versus 38 to 40 , respectively), and in the number of total anal-fin rays (29 versus 25 to 27 , respectively). Denticetopsis iwokrama differs from $D$. macilenta in the number of caudal (32 versus 28 to 30, respectively), preanal (17 versus 14 to 16 , respectively), and total vertebrae (43 versus 40 or 41 , respectively), the position of the middle of the orbit (located at anterior 0.25 of HL versus $0.18-0.19$ of SL, respectively), and in the width of the head as a proportion of the length of the head (head width/HL 0.72 versus $0.77-0.84$, respectively). Denticetopsis iwokrama differs from $D$. praecox in the number of caudal (32 versus 27 to 30, respectively), preanal (17 versus 14 to 15 , respectively), and total vertebrae (43 versus 38 to 41 , respectively), and in the pigmentation of the caudal fin (without a distinct, pale region in the distal portions of the middle fin rays versus with a pale region in the distal portions of the middle fin rays, respectively). Denticetopsis iwokrama differs from $D$. seducta in the number of caudal (32 versus 26 to 31 , respectively), preanal (17 versus 14 to 17 with 17 in only 


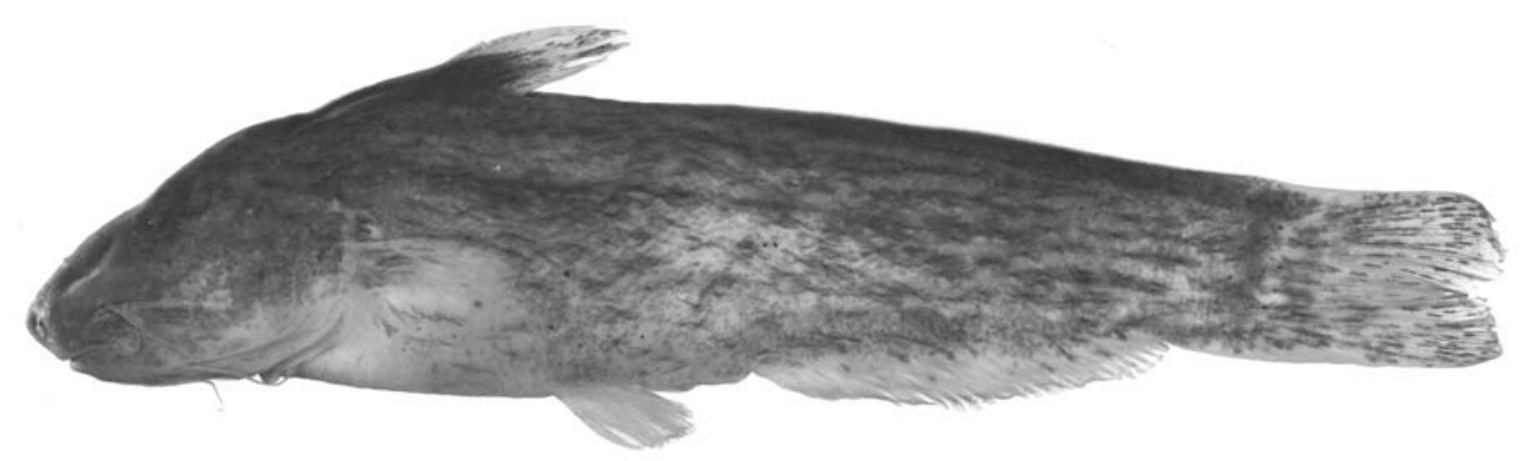

Fig. 47. Denticetopsis iwokrama, new species, holotype, ANSP 177215, 43 mm SL; Guyana, Essequibo, Siparuni River at Tumble Down Creek, Essequibo River basin (448'39"N, 5851'11"W).

1 of 23 specimens, respectively), and total vertebrae (43 versus 39 to 42 with 42 in only 1 of 31 specimens, respectively), and in the pigmentation of the pectoral fin (lightly pigmented versus heavily pigmented, respectively).

Description. Body moderately-elongate, slightly-compressed laterally anteriorly and becoming progressively distinctlycompressed posteriorly. Body depth at dorsal-fin origin approximately $0.23-0.25$ of SL, and slightly longer than distance from anterior margin of orbit to posterior margin of opercle. Lateral line on body complete, unbranched, and midlateral; and extending from vertical through pectoral-fin base to caudal peduncle but falling short of posterior margin of hypural plate. Dorsal profile of body slightly convex from nape to dorsal-fin origin and straight from dorsal-fin origin to caudalfin base. Ventral profile of body slightly convex along abdomen, approximately straight, but posterodorsally-slanted, along base of anal fin. Caudal-peduncle depth nearly 1.4 times caudal-peduncle length.

Head in profile acutely triangular overall with bluntlypointed snout. Dorsal profile of head slightly convex from tip of snout to nape. Ventral profile of head slightly convex. Margin of snout in dorsal view rounded. Postorbital margins of head running nearly in parallel from dorsal view. Enlarged jaw musculature evident externally on dorsal surface of postorbital portion of head.

Opercular membrane attaching to isthmus only anterior of vertical through pectoral-fin insertion. Opercular opening moderate; extending ventral of pectoral-fin insertion by distance slightly greater than distance from tip of snout to posterior margin of orbit and extending dorsal of pectoral-fin insertion by distance equal to diameter of eye.

Eye situated on lateral surface of head; located entirely dorsal to horizontal extending through pectoral-fin insertion; eye visible in dorsal view, but not in ventral view, of head. Middle of orbit at approximately anterior 0.27 of HL. Eye diameter approximately one-half of snout length. Interorbital width slightly greater than distance from tip of snout to posterior margin of orbit. Anterior narial opening circular, surrounded by short, anteriorly-directed, tubular rim of skin. Opening of anterior nares located along horizontal extending through maxillary-barbel origin and ventral of horizontal extending through tip of snout. Distance between anterior nares slightly greater than distance from tip of snout to middle of eye. Posterior narial opening located on dorsal surface of head, situated along vertical through anterior margin of orbit; narial opening nearly round and completely surrounded by flap of skin of nearly uniform height with posterior margins of flap in contact.

Mouth inferior; its width approximately one-half of HL. Margin of lower jaw gently rounded, its posterior limit reaching to vertical through posterior margin of orbit. Premaxillary tooth patch in form of gently-arched band continuous across midline and with anterior margin convex and posterior margin concave and running in parallel to anterior margin. Teeth on premaxilla small, conical, sharply-pointed, and arranged in two, regular rows of uniform-sized teeth across premaxillae, with third irregular row situated anterior to other tooth rows on medial portion of premaxilla. Vomerine teeth arranged in single, arched row with small gap in tooth series at midline. Vomerine teeth stout, conical, and becoming progressively larger in lateral portion of tooth row, but with even smallest teeth on vomer much larger than teeth present on premaxilla. Dentary teeth comparable in shape to, but larger in size than, premaxillary teeth. Dentary dentition arranged in irregular patch, with three rows of teeth medially that taper to one tooth row laterally.

Maxillary barbel slender, its length greater than distance from tip of snout to rear of eye, and approximately one-half of HL; barbel origin located ventral to middle of orbit. Medial mental barbel slightly shorter than lateral mental barbel with latter approximately equal in length to maxillary barbel. Medial mental-barbel origin located along vertical through rictus. Lateral mental-barbel origin situated slightly posterior of vertical through medial mental-barbel origin. Tips of adpressed mental barbels falling just short of posterior margin of opercle.

Dorsal fin moderately large overall with length of dorsalfin base approximately $0.32-0.34$ of HL. Length of longest branched dorsal-fin ray equal to approximately one-half of HL. Dorsal-fin spinelet absent. First dorsal-fin ray spinous for basal one-half of its length and flexible more distally, and lacking distal filament present in some species of Cetopsinae. 
Distal margin of dorsal fin convex, with second branched ray longest. Dorsal-fin origin located at approximately anterior 0.29-0.31 of SL and along vertical extending through middle of adpressed pectoral fin. Tip of adpressed dorsal fin falling short of vertical through vent. Posterior most dorsal-fin ray without posterior, membranous attachment to body.

Caudal fin shallowly-forked, symmetrical; tips of lobes rounded. Length of longest caudal-fin ray approximately 1.4 times length of middle fin rays.

Base of anal fin moderately long. Anal-fin origin located distinctly posterior of middle of SL and approximately at middle of TL. Anal-fin margin slightly convex. Membranous attachment present between posterior margin of basal two-thirds of posterior most anal-fin ray and caudal peduncle.

Pelvic fin moderate; distal margin slightly convex, with middle fin rays longest. Pelvic-fin insertion located anterior to middle of SL and posterior of vertical through posterior terminus of base of dorsal fin. Tip of adpressed pelvic fin extending past middle of SL to posterior margin of vent. Medial most pelvic-fin ray with membranous attachment to body along basal one-fourth of its length.

Pectoral-fin length approximately one-half of HL. Pectoral-fin margin distinctly convex with middle ray longest. First pectoral-fin ray spinous with smooth margins and proportionally short with length approximately one-half that of first branched ray.

Coloration in alcohol. Overall coloration of most of head and body dark, but only slightly darker dorsally. Abdomen pale. Dark coloration primarily formed of large, stellate, horizontally-elongated chromatophores when chromatophores expanded. Compressed chromatophores appearing as discrete dark specks. Head dark dorsally, more so on snout, with dark pigmentation extending as far ventrally as horizontal extending through rictus of mouth. Head pale ventrally except for broad, dusky region around lower lip.

Dorsal fin dark on basal one-half except for pale anterior and posterior most rays; distal one-half of fin pale except for scattered, dark pigmentation on distal portions of middle fin rays. Anal fin with scattered, dark pigmentation somewhat more concentrated basally. Caudal fin largely pale except for dusky region basally. Pelvic fin pale, without dark chromatophores. Pectoral fin with few scattered, dark chromatophores basally.

Maxillary barbel dusky basally and pale distally. Mental barbels pale.

Sexual dimorphism. Inasmuch as only one specimen of Denticetopsis iwokrama is available, it is impossible to determine whether this species demonstrates the sexual dimorphism of the dorsal, pectoral, and anal fins that is present in many species of the Cetopsinae, albeit not the other species of Denticetopsis.

Distribution. Denticetopsis iwokrama is only known from the type locality in the Siparuni River basin, Guyana (Fig. 46).
Etymology. The specific name, iwokrama, is in reference to the Iwokrama rainforest project in the region of Guyana from which the holotype of the species was collected. It is a noun in apposition.

Remarks. Denticetopsis iwokrama is most similar to $D$. seducta, a species of the central and western portions of the Amazon basin. The two species demonstrate a distinct difference in the number of caudal and total vertebrae (see Tables 21,22 ) and the pigmentation pattern of the pectoral fin and we consequently recognize them as different despite the limited available sample of D. iwokrama.

Material examined. 1 specimen (43 mm SL). Holotype. Guyana. Essequibo: Siparuni River at Tumble Down Creek, Essequibo River basin (448'39"N, 58 51'11"W), G. Watkins et al., 8 December 1997, ANSP 177215, 1 (43).

\section{Denticetopsis macilenta (Eigenmann, 1912)}

Figs. 46, 48-49, Tables 16-22

Hemicetopsis macilentus Eigenmann, 1912a: 211, pl. 23, fig. 1 [type locality: British Guiana (=Guyana), Creek below Potaro Landing].-Henn, 1928: 81 [holotype depository].Ibarra \& Stewart, 1997: 44 [holotype depository].-Burgess, 1989: 291 [literature compilation, not habitat data taken from Fernández-Yépez, 1972a].-[not FernándezYépez, 1972a: 19, fig. on page 20; not Lasso, 1992: 19].

Pseudocetopsis macilentus.-Schultz, 1944: 252 [in key to species of Pseudocetopsis].-Evers \& Seidel, 2002: 741 [listing].-Vari \& Ferraris, 2003: 259 [in check list; distribution].

Diagnosis. Denticetopsis macilenta is distinguished from $D$. royero $i$ and $D$. sauli by the combination of the lack of elongate, symphyseal teeth on the dentary, the lateral line extending posteriorly on the body beyond the abdomen at least onto the caudal peduncle, the presence of dentition on the vomer, a dorsal fin with 5 or 6 segmented rays and with a first ray that is spinous basally, a symmetrical, shallowly-forked caudal fin, and the possession of horizontally-elongate, stellate, dark chromatophores when the chromatophores are expanded. Denticetopsis macilenta differs from D. epa in the proportional length of the pelvic fin (reaching just anterior of the anterior margin of the vent versus to the posterior margin of the vent, respectively) and in the relative position of the eye (located at anterior 0.18-0.19 of HL versus 0.25 of HL, respectively). Denticetopsis macilenta differs from $D$. praecox in the relative position of the eye (located at anterior 0.180.19 of HL versus $0.25-0.26$ of HL, respectively), the number of irregular rows of teeth on the median portions of the premaxilla (three versus two, respectively), in the profiles of the postorbital portion of the head from a dorsal view (convex versus approximately straight, respectively), and in the width of the head as a proportion of the length of the head (head width/HL 0.77-0.84 versus 0.71-0.74, respectively). 


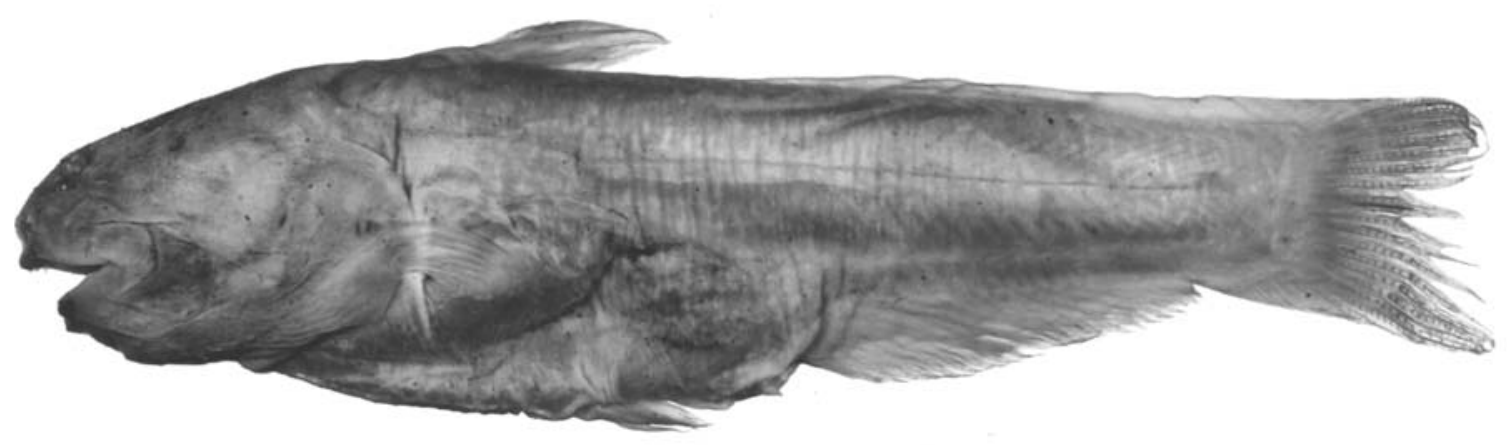

Fig. 48. Denticetopsis macilenta, holotype of Hemicetopsis macilentus, FMNH 53260, $44 \mathrm{~mm}$ SL; Guyana, creek below Potaro Landing $\left(5^{\circ} 23^{\prime} \mathrm{N}, 59^{\circ} 08^{\prime} \mathrm{W}\right)$.

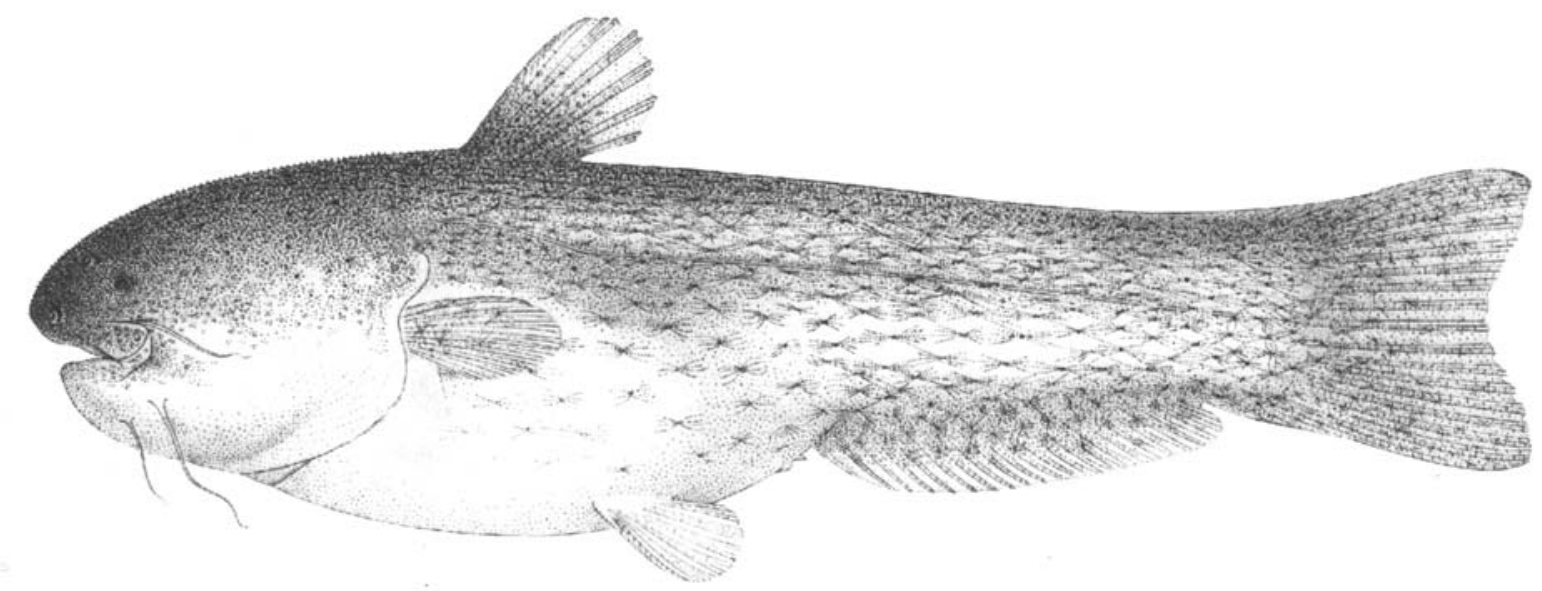

Fig. 49. Denticetopsis macilenta, original illustration of holotype of Hemicetopsis macilentus (Eigenmann, 1912b, pl. 23, fig. 1), showing distribution of pigmentation and form of horizontally-elongate, dark chromatophores on body.

Denticetopsis macilenta differs from D. iwokrama in the number of caudal (28 to 30 versus 32), preanal (14 to 16 versus 17), and total vertebrae (40 or 41 versus 43 ), the position of the middle of the orbit (located at anterior 0.18-0.19 of HL versus 0.25 of SL, respectively), and in the width of the head as a proportion of the length of the head (head width/HL 0.77-0.84 versus 0.72 , respectively). Denticetopsis macilenta differs from $D$. seducta in the position of the middle of the orbit (at anterior $0.18-0.19$ of HL versus $0.25-0.27$ of HL, respectively) and in width of the head as a proportion of the length of the head (head width/HL $0.77-0.84$ of HL versus 0.61-0.70 of HL, respectively).

Description. Body moderately stout, very slightly compressed laterally anteriorly and becoming progressively distinctlycompressed posteriorly. Body depth at dorsal-fin origin approximately $0.26-0.27$ of SL, and slightly less than HL. Lateral line on body complete, unbranched, and midlateral; extending from vertical through pectoral-fin base to onto caudal peduncle but falling short of posterior margin of hypural plate. Dorsal profile of body straight from nape to dorsal-fin origin and straight from dorsal-fin origin to caudal-fin base. Ventral profile of body convex along abdomen, approximately straight, but posterodorsally-slanted, along base of anal fin. Caudal- peduncle depth approximately 1.5 times caudal-peduncle length.

Head in profile distinctly rounded overall with distinctlyrounded snout. Dorsal profile of head distinctly convex from tip of snout to nape. Ventral profile of head distinctly convex. Margin of snout in dorsal view rounded. Postorbital margins of head convex from dorsal view. Enlarged jaw musculature evident externally on dorsal surface of postorbital portion of head.

Opercular membrane attaching to isthmus only anterior of vertical through pectoral-fin insertion. Opercular opening moderate; extending ventral of pectoral-fin insertion by distance equal to distance from tip of snout to posterior margin of orbit and extending dorsal of pectoral-fin insertion by distance equal to width of eye.

Eye situated on lateral surface of head; located entirely dorsal to horizontal extending through pectoral-fin insertion; eye visible in dorsal view, but not in ventral view, of head. Middle of orbit at approximately anterior 0.18-0.19 of HL. Eye diameter approximately two-thirds of snout length. Interorbital width 1.5 times distance from tip of snout to posterior margin of orbit. Anterior narial opening circular, surrounded by short, anteriorly-directed, tubular rim of skin. Opening of anterior nares located along horizontal extending through 
maxillary-barbel origin. Distance between anterior nares approximately equal to distance from tip of snout to posterior margin of orbit. Posterior narial opening located on dorsal surface of head, situated dorsal to anterior half of orbit; narial opening nearly round and completely surrounded by flap of skin of nearly uniform height and with posterior margins of flap in contact.

Mouth inferior; its width approximately two-thirds of HL. Margin of lower jaw gently rounded, its posterior limit reaching to vertical through posterior margin of orbit. Premaxillary tooth patch in form of gently-arched band continuous across midline and with anterior margin convex and posterior margin concave and running in parallel to anterior margin. Teeth on premaxilla small, conical, uniformly-sized, sharply-pointed, and arranged in three, irregular rows medially that taper to two rows laterally. Vomerine teeth arranged in single, arched row with small gap in tooth series at midline. Vomerine teeth stout, conical, and become progressively larger laterally, but with even smallest teeth in series much larger than teeth on premaxilla. Dentary teeth comparable in shape to, but larger in size than, premaxillary teeth. Dentary dentition consisting of three or four irregular rows medially that abruptly taper to one tooth row laterally.

Maxillary barbel slender, its length distinctly longer than distance from tip of snout to rear of eye, and approximately 0.40 of HL; barbel origin located ventral to middle of orbit. Medial mental barbel slightly shorter than lateral mental barbel, with latter approximately equal in length to maxillary barbel. Medial mental-barbel origin located along vertical through rictus. Lateral mental-barbel origin situated slightly posterior of vertical through medial mental-barbel origin. Tips of adpressed mental barbels falling short of posterior margin of opercle.

Dorsal fin moderately large overall with length of dorsalfin base approximately $0.33-0.34$ of HL. Length of longest branched dorsal-fin ray equal to approximately one-half of HL. Dorsal-fin spinelet absent. First dorsal-fin ray spinous for basal one-half of length but flexible more distally and without distal filament present in some other species of Cetopsinae. Distal margin of dorsal fin convex, with second branched ray longest. Dorsal-fin origin located at approximately anterior 0.37 of SL and along vertical extending through middle of adpressed pectoral fin. Tip of adpressed dorsal fin falling short of vertical through vent. Posterior most dorsal-fin ray without posterior, membranous attachment to caudal peduncle.

Caudal fin shallowly-forked, symmetrical; tips of lobes bluntly pointed. Length of longest caudal-fin ray approximately 1.5 times length of middle fin rays.

Base of anal fin moderately long. Anal-fin origin located distinctly posterior of middle of SL and approximately at middle of TL. Anal-fin margin slightly convex in all examined specimens. Membranous attachment present between posterior margin of basal two-thirds of posterior most anal-fin ray and body.

Pelvic fin moderate; distal margin slightly convex with middle fin rays longest. Pelvic-fin insertion located anterior to middle of SL and posterior of vertical through posterior terminus of base of dorsal fin. Tip of adpressed pelvic fin extending past middle of SL, but falling just short of anterior margin of vent. Medial most pelvic-fin ray with membranous attachment to body along basal one-fourth of its length.

Pectoral-fin length approximately one-half of HL. Pectoral-fin margin slightly convex, with middle ray longest. First pectoral-fin ray spinous with smooth margins; ray proportionally short with length approximately one-half of first branched ray.

Coloration in alcohol. Examined specimens largely depigmented. Eigenmann (1912a: 211) reported that Denticetopsis macilenta (the Hemicetopsis macilenta of that author) has "upper surface of head grey; sides with numerous chromatophores, whose rays branch forward and backward from center of cell, giving a strigose effect and looking like little bundles of sticks tied in the middle." This description is presumably a reference to the horizontally-elongate, expanded, dark chromatophores that are present in most other species of Denticetopsis. The drawing of the holotype in Eigenmann (1912a, pl. 23, fig. 1) showed overall coloration of head and body darker dorsally with abdomen head pale. Dorsal portion of head illustrated as dark as far as ventrally as horizontal extending through pectoral-fin insertion, and pale ventrally except in region of lower lip.

Dorsal fin dark for basal one-half; remainder of fin pale. Anal fin dusky basally, becoming paler distally. Caudal fin with scattered, dark, stellate, chromatophores. Chromatophores less concentrated distally. Pelvic fin pale. Pectoral fin apparently pale.

All barbels apparently pale.

Sexual dimorphism. Examined specimens of Denticetopsis macilenta lack the sexual dimorphism of the dorsal, pectoral, and anal fins that is characteristic of many species within the Cetopsinae, albeit not the other species of Denticetopsis.

Distribution. Denticetopsis macilenta is only known from a limited area in the Potaro River basin of northern Guyana (Fig. 46).

Remarks. Fernández-Yépez (1972a: 19) reported on specimens from the río Aguaro in the state of Guarico, Venezuela, that he identified as Hemicetopsis macilentus. The results of this study indicate, however, that Denticetopsis macilenta is apparently endemic to the Essequibo River basin, Guyana, a considerable distance to the east of the río Aguaro and in a completely different major drainage basin. Furthermore, the specimen illustrated by Fernández-Yépez (1972a: 20) differs in appearance from both the type and non-type specimen of Denticetopsis macilenta examined during this study (compare unnambered figure published in Fernández-Yépez (1972a) with Fig. 47 herein), and most likely represents an unnamed form. We have been unable to locate the specimens cited by 
Fernández-Yépez and they, furthermore, were not reported on by Milani de Arnal (1991) in her study of the species of the Cetopsinae of Venezuela. Thus, those specimens are likely no longer extant.

Lasso (1992: 19) reported Hemicetopsis macilentus from the lower portions of the río Suapare in the central portions of Venezuela. We have not examined the specimens that served as the basis for this record, but given the restricted known distribution of Denticetopsis macilenta, it is likely that Lasso's citation of that species from central Venezuela is based on another, perhaps undescribed, species. It is likely that the same situation applies to the report by Machado-Allison et al. (1993: 65) of Hemicetopsis macilentus from localities in the state of Guarico, Venezuela.

Material examined. 9 specimens (29-68 mm SL). Guyana. Kartabo $\left(6^{\circ} 23^{\prime} \mathrm{N}, 58^{\circ} 41^{\prime} \mathrm{W}\right)$, AMNH 27692, 1 (68); AMNH 55332, 4 (3547); AMNH 55332 SW, 2 (approximately 29-32; specimens cleared and stained). Creek below Potaro Landing ( $\left.5^{\circ} 23^{\prime} \mathrm{N}, 59^{\circ} 08^{\prime} \mathrm{W}\right)$, FMNH 53260, 1 (44; holotype of Hemicetopsis macilentus); CAS 64605, 1 (52, paratype of Hemicetopsis macilentus).

\section{Denticetopsis praecox (Ferraris \& Brown, 1991)} Figs. 46, 50, Tables 16-22

Pseudocetopsis praecox Ferraris \& Brown, 1991: 162, fig. 1 [type locality: río Mawarinuma of the río Baria drainage, Territorio Federal Amazonas, southern Venezuela, $\left(0^{\circ} 55^{\circ} \mathrm{N}\right.$, $\left.66^{\circ} 10^{\prime} \mathrm{W}\right)$, elevation $120 \mathrm{~m}$ ].-Ferraris \& Vari, 1992: 16 [paratype depository].-Taphorn et al., 1997: 85 [Venezuela].-Evers \& Seidel, 2002: 741 [listing].-Vari \& Ferraris, 2003: 259 [in check list; distribution].

Diagnosis. Denticetopsis praecox is distinguished from $D$. royero $i$ and $D$. sauli by the combination of the lack of elongate symphyseal teeth on the dentary, the lateral line extending posteriorly on the body beyond the abdomen onto at least the caudal peduncle, the presence of dentition on the vomer, a dorsal fin with 5 or 6 segmented rays and with the first ray that is spinous basally, a symmetrical, shallowlyforked caudal fin, and the possession of horizontally-elongate, stellate, dark chromatophores when the chromatophores are expanded. Denticetopsis praecox differs from D. epa in the relative length of the pelvic fin (tip of fin falling just short of the anterior margin of the vent versus reaching to the posterior margin of the vent, respectively) and in the number of premaxillary tooth rows (two rows of teeth versus three rows of teeth on premaxilla in all but the smallest examined specimens, respectively). Denticetopsis praecox differs from $D$. iwokrama in the number of preanal (14 to 15 versus 17, respectively), caudal ( 27 to 30 versus 32 , respectively), and total vertebrae (38 to 40 versus 43 , respectively), and in the pigmentation of the caudal-fin (a distinct, pale region present on distal portions of the middle fin rays versus a distinct, pale region in the distal portions of the middle fin rays absent, respectively). Denticetopsis praecox differs from $D$. macilenta in the relative position of the eye (located at anterior 0.25 of HL versus at anterior 0.18-0.19 of HL, respectively), the number of irregular rows of teeth on the median portions of the premaxilla (two versus three, respectively), in the profile of the postorbital portion of the head in dorsal view (convex versus approximately straight, respectively), and in the width of the head as a proportion of the length of the head (head width/HL 0.71-0.74 versus 0.77-0.84, respectively). Denticetopsis praecox differs from $D$. seducta in the pigmentation on the caudal fin (the presence of a distinct, pale region in the distal portions of the middle fin rays present versus the absence of a distinct, pale region in the distal portions of middle fin rays, respectively) and in the number of premaxillary tooth rows (two rows of teeth versus typically three rows in all but smallest examined specimens, respectively).

Description. Body moderately-elongate, slightly laterallycompressed anteriorly and becoming progressively distinctlycompressed posteriorly. Body depth at dorsal-fin origin approximately $0.27-0.28$ of SL, and approximately equal to distance from anterior margin of eye to posterior margin of opercle. Lateral line on body complete, unbranched, and midlateral; extending from vertical through pectoral-fin base to onto caudal peduncle but falling short of posterior margin of hypural plate. Dorsal profile of body straight from nape to dorsal-fin origin and straight from dorsal-fin origin to caudalfin base. Ventral profile of body convex along abdomen, approximately straight, but posterodorsally-slanted, along base of anal fin. Caudal-peduncle depth nearly two times caudalpeduncle length.

Head in profile acutely triangular overall with bluntlypointed snout. Dorsal profile of head slightly convex from tip of snout to nape. Ventral profile of head slightly convex. Margin of snout in dorsal view rounded to bluntly triangular. Postorbital margins of head running nearly in parallel from dorsal view. Enlarged jaw musculature evident externally on dorsal surface of postorbital portion of head.

Opercular membrane attaching to isthmus only anterior of vertical through pectoral-fin insertion. Opercular opening moderate; extending ventral of pectoral-fin insertion by distance equal to length of snout plus eye and extending dorsal of pectoral-fin insertion by distance equal to width of eye.

Eye situated on lateral surface of head; located entirely dorsal to horizontal extending through pectoral-fin insertion; eye visible in dorsal view, but not in ventral view, of head. Middle of orbit at approximately anterior one-fourth of HL. Eye diameter approximately one-half of snout length. Interorbital width slightly greater than distance from tip of snout to posterior margin of orbit. Anterior narial opening circular, surrounded by short, anteriorly-directed, tubular rim of skin. Opening of anterior nares located along horizontal extending through maxillary-barbel origin and ventral of horizontal extending through tip of snout. Distance between anterior nares approximately equal to distance from tip of snout to middle of eye. Posterior narial opening located on dorsal surface of head, situated along vertical through anterior margin of orbit; 


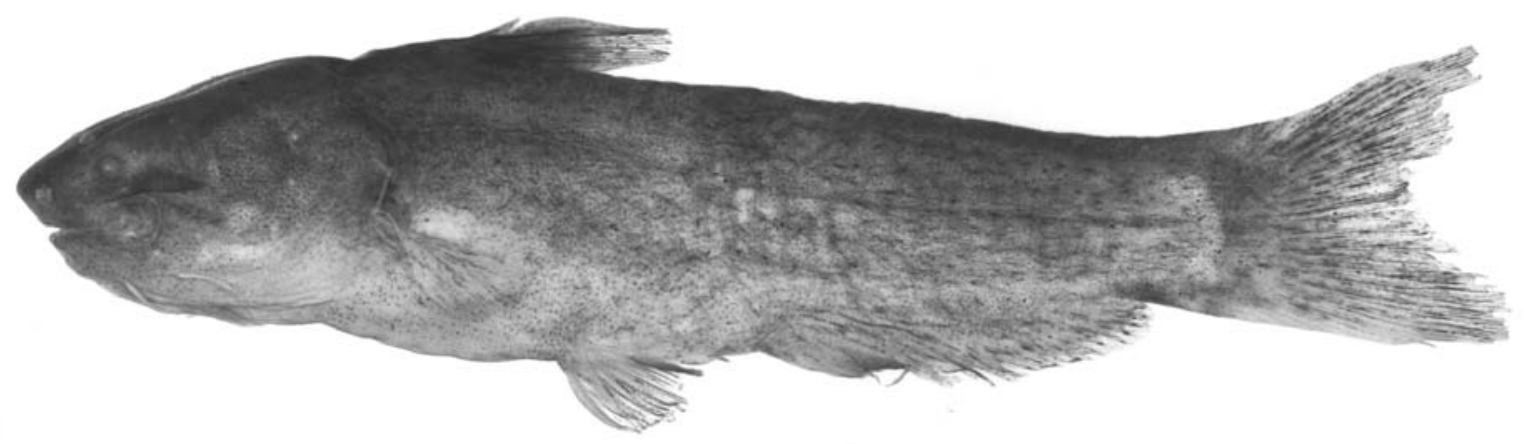

Fig. 50. Denticetopsis praecox, paratype of Pseudocetopsis praecox, AMNH 74445, 46 mm SL; Venezuela, Amazonas, río Baria, above Neblina base camp.

narial opening nearly round and completely surrounded by flap of skin of nearly uniform height and with posterior margins of flap in contact.

Mouth inferior; its width approximately one-half of HL. Margin of lower jaw gently rounded, its posterior limit reaching to vertical through posterior margin of orbit. Premaxillary tooth patch in form of gently-arched band continuous across midline with anterior margin convex and posterior margin concave and running in parallel to anterior margin. Teeth on premaxilla small, conical, and sharply-pointed, with teeth arranged in two, regular rows of uniform-sized teeth. Vomerine teeth arranged in single, arched row with small median gap in tooth series. Vomerine teeth stout, conical, and becoming progressively larger laterally, with even smallest teeth in series much larger than teeth on premaxilla. Dentary teeth comparable in shape to, but larger in size than, premaxillary teeth. Dentary dentition consisting of two regular rows medially that taper to one tooth row laterally.

Maxillary barbel slender, its length approximately equal to distance from tip of snout to rear of eye, and approximately one-third of HL; barbel origin located ventral to middle of orbit. Medial mental barbel slightly shorter than lateral mental barbel, with latter approximately equal in length to maxillary barbel. Medial mental-barbel origin located along vertical through rictus. Lateral mental-barbel origin situated slightly posterior of vertical through medial mental-barbel origin. Tips of adpressed mental barbels falling short of posterior margin of opercle.

Dorsal fin moderately large overall with length of dorsalfin base approximately $0.32-0.35$ of HL. Length of longest branched dorsal-fin ray equal to approximately one-half of HL. Dorsal-fin spinelet absent. First dorsal-fin ray spinous for basal one-half of length but flexible more distally and without distal filament present in some other species of Cetopsinae. Distal margin of dorsal fin convex, with second branched ray longest. Dorsal-fin origin located at approximately anterior 0.36-0.37 of SL and along vertical extending through middle of adpressed pectoral fin. Tip of adpressed dorsal fin falling short of vertical through vent. Posterior most dorsal-fin ray without posterior, membranous attachment to body.

Caudal fin shallowly-forked, symmetrical; tips of lobes bluntly pointed. Length of longest caudal-fin ray approximately 1.5 times length of middle fin rays.

Base of anal fin moderately long. Anal-fin origin located distinctly posterior of middle of SL and approximately at middle of TL. Anal-fin margin slightly convex. Membranous attachment present between posterior margin of basal one-half of posterior most anal-fin ray and body.

Pelvic fin moderate; distal margin slightly convex with middle fin rays longest. Pelvic-fin insertion located anterior to middle of SL and posterior of vertical through posterior terminus of base of dorsal fin. Tip of adpressed pelvic fin extending past middle of SL, but falling just short of anterior margin of vent. Medial most pelvic-fin ray with membranous attachment to body along basal one-fourth of its length.

Pectoral-fin length approximately one-half of HL. Pectoral-fin margin slightly convex with middle ray longest. First pectoral-fin ray spinous with smooth margins, short with length approximately one-half of first branched ray.

Coloration in alcohol. Overall coloration of head and body dark, only slightly darker dorsally. Abdomen pale. Specimens with more intense overall pigmentation with dark coloration primarily formed of large, stellate, horizontally-elongate chromatophores when chromatophores expanded. Chromatophores appearing as series of dark specks against lighter background in specimens with contracted chromatophores. Head dark dorsally, with dark coloration continuing as far ventrally as horizontal extending through pectoral-fin insertion. Head pale ventrally except in region of lower lip.

Dorsal fin dark across basal one-half except for pale anterior and posterior most rays; distal one-half of fin pale. Anal fin dusky basally, progressively paler distally. Caudal fin dusky except for pale distal portion of middle fin rays. Pelvic fin pale or with scattered, dark chromatophores on basal region. Pectoral fin with scattered, dark chromatophores basally and becoming progressively paler distally.

Maxillary barbel with dusky, basal pigmentation and pale distally. Mental barbels pale or with scattered, dark pigmentation basally.

Sexual dimorphism. Examined specimens of Denticetopsis 
praecox lack the sexual dimorphism of the dorsal, pectoral, and anal fins that is characteristic of many species within the Cetopsinae, albeit not the other species of Denticetopsis. It appears that the size of sexual maturity may be sexually-dimorphic in this species (see "Biology" below).

Distribution. Denticetopsis praecox is known from the río Baria of the upper río Negro basin in southern Venezuela (Fig. 46).

Biology. According to Ferraris \& Brown (1991: 164), specimens of Denticetopsis praecox were captured in a cobblepebble habitat of black water streams that ranged in $\mathrm{pH}$ from 4.3-5.0. Stomachs of two examined specimens contained larval chironomids and other larval insect remains. Those authors also reported that females of Denticetopsis praecox of 44.3-52.9 mm SL contained mature ova and that males of 23.7$42.0 \mathrm{~mm}$ SL exhibited obvious testes.

Material examined. 17 specimens (17, 25-48 mm SL). Venezuela. Amazonas: río Baria, above Neblina base camp, in black water tributary, AMNH 74445, 4 (34-46, paratypes of Pseudocetopsis praecox; 1 specimen cleared and stained); AMNH 74446, 1 (48, holotype of Pseudocetopsis praecox); AMNH 74447, 2 (27-31, paratypes of Pseudocetopsis praecox). Río Baria, $5 \mathrm{~km}$ above base camp, in tributary, AMNH 74448, 3 (42-44, paratypes of Pseudocetopsis praecox); AMNH 74449, 5 (25-47, paratypes of Pseudocetopsis praecox; 1 specimen, $43 \mathrm{~mm}$, cleared and stained). Río Mawarinuma of río Baria, at Neblina base camp, USNM 309184, 2 (35-40, paratypes of Pseudocetopsis praecox).

\section{Denticetopsis royeroi Ferraris, 1996}

Figs. 46, 51, Tables 16-22

Denticetopsis royeroi Ferraris, 1996: 167, figs. 4, 12 [type locality: Venezuela, Estado Amazonas, Caño Chola at crossing of San Carlos de río Negro to Solano Road, $1^{\circ} 58^{\prime} \mathrm{N}$, 6700’W].-Taphorn et al., 1997: 85 [Venezuela].-Evers \& Seidel, 2002: 741 [listing].-Vari \& Ferraris, 2003: 258 [in check list, distribution].

Diagnosis. Denticetopsis royeroi is distinguished from all of its congeners with the exception of $D$. sauli by the combination of the possession of elongate, symphyseal teeth on the dentary, a reduced lateral line not extending posteriorly on the body beyond the abdomen, an edentulous vomer, a dorsal fin with only 4 segmented rays and without a spinous first ray, an obliquely-truncate margin of caudal fin, and the lack of horizontally-elongate, stellate, dark chromatophores when the chromatophores are expanded. Denticetopsis royeroi is distinguished from $D$. sauli by the relative posterior extent of the margin of the maxilla (extending only slightly beyond the posterior margin of the orbit versus extending at least one eye diameter past the posterior margin of the orbit, respectively), the body depth (23\% of SL versus $17.1-19.5 \%$ of SL, respectively), and the extent of the membranous connection between the caudal and anal fins (membrane without a distinct notch versus distinctly incised, respectively).
Description. Body moderately deep, slightly transverselycompressed anteriorly, becoming increasingly compressed posteriorly. Body depth at dorsal-fin origin equal to length of postorbital portion of head and approximately 0.20 of SL. Lateral line canal incomplete, restricted to abdomen, and limited to canal segment situated posterior of vertical through the posterior limit of base of dorsal fin. Dorsal profile of body straight and very slightly inclined from nape to dorsal-fin origin; nearly straight from dorsal-fin origin to caudal-fin base. Ventral profile of body convex along abdomen, approximately straight, but very slightly posterodorsally-slanted along base of anal fin. Caudal-peduncle length slightly less than onehalf of caudal-peduncle depth.

Head acutely triangular in lateral view and broadly obtusely-rounded anteriorly. Dorsal profile of head slightly convex from tip of snout to posterior nares and straight from nares to posterior of nape. Ventral profile of head gently convex. Profile of snout in dorsal view broadly rounded. Portion of head posterior of nares with lateral margins aligned nearly in parallel in dorsal view. Dorsal surface of posterior portion of head without enlarged jaw musculature apparent externally in many species of Cetopsinae.

Opercular membrane only slightly attached as far posteriorly as vertical through posterior margin of orbit. Opercular opening very wide; extending dorsal of pectoral-fin insertion by distance approximately equal to eye diameter and extending anterior of pectoral-fin insertion for distance equal to approximately one-half of HL.

Eyes situated on lateral surface of head; located entirely dorsal to horizontal extending through pectoral-fin insertion; eye visible in dorsal view, but not in ventral view, of head. Middle of orbit at slightly less than anterior one-third of HL. Eye diameter nearly one-half of snout length. Interorbital width approximately equal to snout length. Anterior narial opening circular, surrounded by short, anteriorly-directed, tubular rim of skin. Opening of anterior nares located at horizontal extending through tip of snout and slightly dorsal to horizontal extending through maxillary-barbel origin. Distance between anterior nares greater than distance from anterior to posterior nares, and approximately equal to distance from tip of snout to posterior margin of orbit. Posterior narial opening large and located near dorsal profile of head and dorsal to region between anterior margin and middle of eye; opening round, with anterior portions of aperture bordered by flap of skin, flap highest anteriorly. Distance between posterior nares slightly less than distance between anterior nares.

Mouth inferior; its width approximately two-thirds of HL. Margin of lower jaw broadly rounded, its posterior extent reaching beyond vertical through posterior margin of eye by distance equal to one eye diameter. Premaxillary tooth patch elongate, continuous across midline; anterior margin convex, posterior margin concave and running in parallel to anterior margin. Teeth in upper jaw small, conical, and sharply-pointed. Vomerine teeth absent. Oral surface of dentary at symphysis expanded medially and bearing irregular patch of somewhat larger conical teeth. 


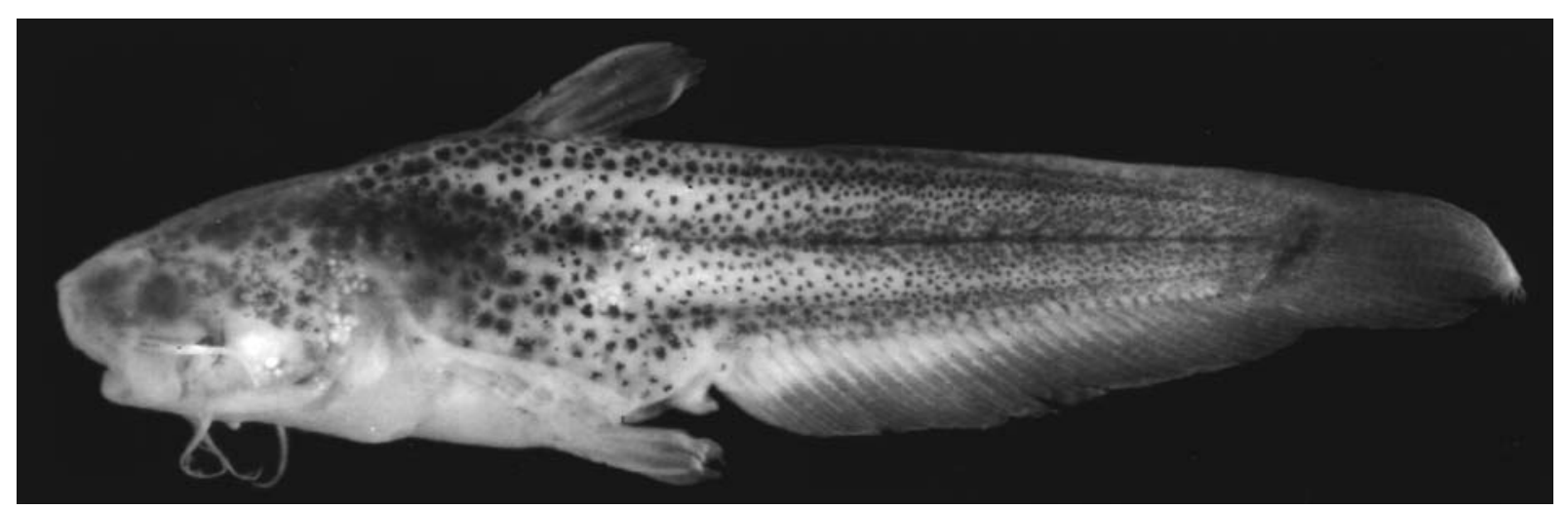

Fig. 51. Denticetopsis royeroi, holotype, MBUCV V-26785, $18.5 \mathrm{~mm}$ SL; Venezuela, Amazonas, Caño Chola, at crossing of road from San Carlos de río Negro to Solano $\left(1^{\circ} 58^{\prime} \mathrm{N}, 67^{\circ} 00^{\prime} \mathrm{W}\right)$ (photo taken shortly after capture).

Maxillary barbel slender, its length slightly greater than one-half of HL; barbel origin located near vertical through anterior margin of orbit. Mental barbels slightly shorter than maxillary barbel. Medial mental-barbel origin located along vertical through middle of orbit. Lateral mental-barbel origin located slightly posterior of vertical through posterior margin of orbit. Tips of adpressed mental barbels falling short of posterior margin of opercle.

Dorsal fin moderately large overall with length of dorsalfin base approximately $0.22-0.26$ of HL and equal to distance from tip of snout to middle of orbit. Longest dorsal-fin ray slightly less than one-half of HL. Dorsal-fin spinelet absent. First dorsal-fin ray spinous for basal one-half, segmented but flexible distally and without distal filament. Distal margin of dorsal fin slightly convex. Dorsal-fin origin located at approximately anterior $0.39-0.40$ of SL and along vertical through middle of adpressed pectoral fin. Tip of adpressed dorsal fin reaching to vertical through anal-fin origin. Posterior most dorsal-fin ray without posterior, membranous attachment to body.

Caudal fin margin obliquely-truncate with dorsal principal fin rays longest. Length of dorsal most principal caudalfin ray approximately 1.5 times length of ventral most fin ray.

Base of anal fin long, approximately 0.40 of SL. Anal-fin origin located along vertical through middle of SL. Anal-fin margin nearly straight, with rays of approximately equal length. Posterior most anal-fin ray with posterior, membranous attachment to first procurrent caudal-fin ray for entire length of ray.

Pelvic fin moderate with distal margin convex and middle fin rays longest. Pelvic fin located entirely anterior to vertical through middle of SL, with pelvic-fin insertion situated along vertical through posterior portion of base of dorsal fin. Tip of adpressed pelvic fin falling slightly short of anal-fin origin. Medial most pelvic-fin ray with membranous attachment to body for basal one-fourth to one-third of its length.

Pectoral-fin length approximately one-half of HL. Pectoral-fin margin very slightly convex, with middle fin rays longest. First pectoral-fin ray somewhat spinous, but flexible dis- tally and without either serrations or distal filament.

Coloration in alcohol. Overall ground coloration of body creamy white with fine, brown, stellate chromatophores that when fully expanded approximately equal to, or less than, width of eye. Dorsal and lateral surfaces of nape, snout, and head with few scattered, dark chromatophores extending as far ventrally as horizontal running through eye. Portion of cheek ventral of orbit, operculum, and ventral surface of head and abdomen with few widely-scattered, dark chromatophores. Larger chromatophores present on head and lateral surface of body anterior to vertical through vent, with chromatophores located more posteriorly in that region notably smaller. Chromatophores evenly distributed over most of caudal region, but more densely concentrated on, and along side of, dorsal midline. Single row of dark chromatophores situated dorsal to base of anal fin.

Dorsal fin with diffuse, dark spot no larger than eye covering base of first two fin rays. Pectoral, pelvic, and anal fins without dark pigmentation. Caudal fin with small dark chromatophores irregularly arranged along margins of each ray.

Barbels unpigmented or with only one or two, dark spots basally.

Sexual dimorphism. Inasmuch as only one specimen of Denticetopsis royeroi is known, it is impossible to evaluate whether this species demonstrates the sexual dimorphism in the dorsal, pectoral, and anal fins that is present in many species within the Cetopsinae, albeit not in the other species of Denticetopsis.

Distribution. Denticetopsis royeroi is only known from the holotype collected in a tributary to the upper río Negro, Venezuela (Fig. 46).

Material examined. 1 specimen (18.5 mm SL). Venezuela Amazonas: Caño Chola, at crossing of road from San Carlos de río Negro to Solano ( $\left.1^{\circ} 58^{\prime} \mathrm{N}, 67^{\circ} 00^{\prime} \mathrm{W}\right)$, MBUCV V-26785, 1 (18.5, holotype of Denticetopsis royeroi). 


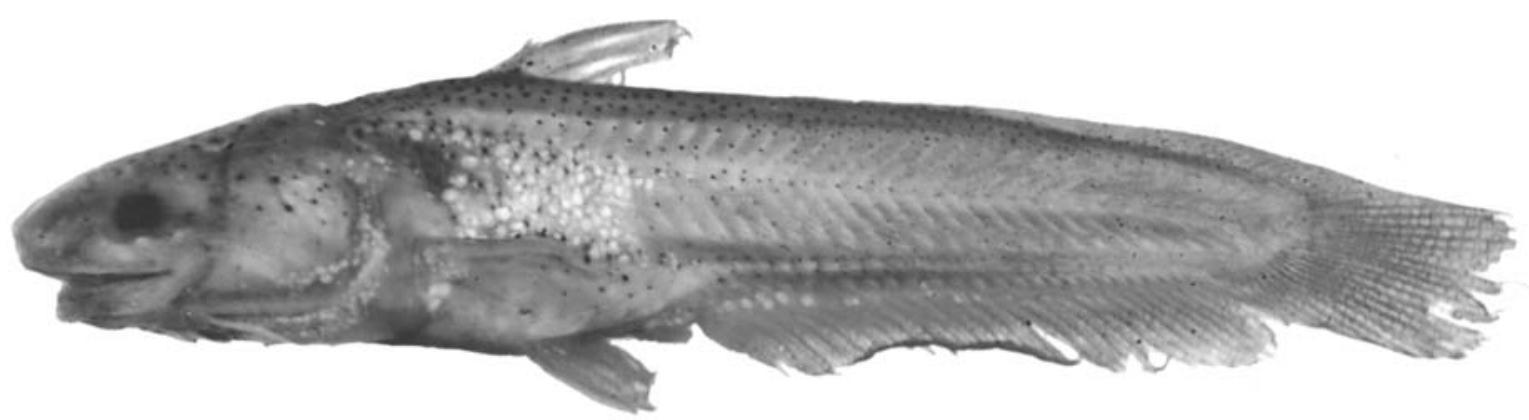

Fig. 52. Denticetopsis sauli, paratype, ANSP 161432, $16.5 \mathrm{~mm}$ SL; Venezuela, Amazonas, outflow stream from a series of morichales (palm swamps), approximately $5 \mathrm{~km}$ from mouth of río Pamoni, río Casiquiare basin $\left(2^{\circ} 48^{`} \mathrm{~N}, 65^{\circ} 53^{`} \mathrm{~W}\right)$.

\section{Denticetopsis sauli Ferraris, 1996}

Figs. 46, 52, Tables 16-22

Denticetopsis sauli Ferraris, 1996: 164, figs. 3, 11 [type locality: Venezuela, Estado Amazonas, outflow stream from series of morichales, ca. $5.0 \mathrm{~km}$ from mouth of río Pamoni, $2^{\circ} 48^{\prime} \mathrm{N}, 65^{\circ} 53^{\prime} \mathrm{W}$ ].-Taphorn et al., 1997: 85 [Venezuela].Evers \& Seidel, 2002: 741 [listing].-Vari \& Ferraris, 2003: 258 [in check list, distribution].

Diagnosis. Denticetopsis sauli is distinguished from all of its congeners with the exception of $D$. royeroi by the combination of the possession of elongate, symphyseal teeth on the dentary, a reduced lateral line not extending posteriorly on the body beyond the abdomen, an edentulous vomer, a dorsal fin with only 4 segmented rays and without a spinous first fin ray, an obliquely-truncate margin on the caudal fin, and the lack of horizontally-elongate, stellate, dark chromatophores when the chromatophores are expanded. Denticetopsis sauli is distinguished from $D$. royeroi by the posterior extent of the margin of the maxilla (extending at least one eye diameter past the posterior margin of the orbit versus extending only slightly beyond the posterior margin of the orbit, respectively), the body depth (17.1-19.5 of SL versus $23 \%$ of $\mathrm{SL}$, respectively), and the extent of the membranous connection between the caudal and anal fins (membrane distinctly incised versus without a distinct notch, respectively).

Description. Body moderately-elongate, slightly transverselycompressed anteriorly, becoming increasingly compressed posteriorly. Body depth at dorsal-fin origin approximately 0.20 of SL and equal to length of postorbital portion of head. Lateral line canal incomplete, interrupted, and restricted to abdomen. Dorsal profile of body straight and very slightly inclined from nape to dorsal-fin origin; nearly straight from dorsal-fin origin to caudal-fin base. Ventral profile of body convex along abdomen, approximately straight, but very slightly posterodorsallyslanted along base of anal fin. Caudal-peduncle length slightly less than one-half of caudal-peduncle depth.

Head acutely triangular overall in lateral view but somewhat rounded anteriorly. Dorsal profile of head slightly con- vex from tip of snout to posterior nares and straight from nares to posterior of nape. Ventral profile of head gently convex. Profile of snout in dorsal view broadly rounded. Portion of head posterior of nares with lateral profiles extending nearly in parallel from dorsal view. Dorsal surface of posterior portion of head without externally apparent enlarged jaw musculature present in many species of Cetopsinae.

Opercular membrane only slightly attached as far posteriorly as vertical through posterior margin of orbit. Opercular opening very wide; extending dorsal of pectoral-fin insertion by distance approximately equal to eye diameter and anterior of pectoral-fin insertion for distance equal to approximately one-half of HL.

Eyes situated on lateral surface of head; located entirely dorsal to horizontal extending through pectoral-fin insertion; eye visible in dorsal view, but not in ventral view, of head. Middle of orbit at slightly less than anterior one-third of HL. Eye diameter between one-third and one-half of snout length. Interorbital width approximately equal to distance from tip of snout to middle of eye. Anterior narial opening circular, surrounded by short, anteriorly-directed, tubular rim of skin. Opening of anterior nares located at horizontal extending through tip of snout and slightly dorsal to horizontal extending through maxillary-barbel origin. Distance between anterior nares much greater than distance from anterior to posterior nares, and approximately equal to distance from tip of snout to posterior margin of orbit. Posterior narial opening large, located near dorsal profile of head, and within region between verticals through anterior margin and middle of eye. Opening round, with anterior portions of aperture bordered by flap of skin; flap highest anteriorly. Distance between posterior nares slightly less than distance between anterior nares.

Mouth inferior; its width approximately two-thirds of HL. Margin of lower jaw broadly rounded, its posterior extent reaching beyond vertical through posterior margin of eye for distance equal to one eye diameter. Premaxillary tooth patch elongate, continuous across midline; anterior margin convex, posterior margin concave and running in parallel to anterior margin. Teeth in upper jaw small, conical, and sharply-pointed, with teeth arranged in two rows at symphysis and reduced to one row laterally. Teeth of both rows of approximately same 
size, except for two or three, enlarged teeth located at lateral limit of premaxilla. Vomerine teeth absent. Dentary with single row of small, conical teeth extending from base of coronoid process midway to symphysis and with second tooth row located anterior to, and along, lateral portion of primary tooth row. Oral surface of dentary at symphysis expanded medially and bearing irregular patch of large, conical teeth. Smaller teeth of primary dentary tooth row located anterior to enlarged teeth situated proximate to dentary symphysis.

Maxillary barbel slender, its length distinctly greater than distance from tip of snout to posterior margin of orbit and approximately equal to one-half of HL; barbel origin located near vertical through anterior margin of orbit. Mental barbels approximately equal in size to, but slightly shorter than, maxillary barbel. Medial mental-barbel origin located along vertical through middle of orbit. Lateral mental-barbel origin located slightly posterior of vertical through posterior margin of orbit. Tips of adpressed mental barbels falling short of posterior margin of opercle.

Dorsal fin moderately large overall with length of dorsalfin base approximately $0.22-0.26$ of HL and equal to distance from tip of snout to middle of orbit. Length of longest dorsalfin ray equal to slightly less that one-half of HL. Dorsal-fin spinelet absent. First dorsal-fin ray spinous for basal onehalf, ray segmented and flexible distally and without distal filament. Distal margin of dorsal fin slightly convex, with second branched ray longest. Dorsal-fin origin located at approximately anterior one-third of SL and along vertical through middle of adpressed pectoral fin. Tip of adpressed dorsal fin reaching to vertical through anal-fin origin. Posterior most dorsal-fin ray without posterior, membranous attachment to body.

Caudal-fin margin obliquely-truncate with dorsal principal-fin rays longest. Length of dorsal most principal caudalfin ray approximately 1.5 times length of ventral most fin ray.

Base of anal fin long, approximately $0.40-0.41$ of SL. Analfin origin located approximately along vertical through middle of SL. Anal-fin margin nearly straight, with all rays of approximately equal length. Posterior most anal-fin ray with posterior, membranous attachment along one-half of its length to ventral most procurrent caudal-fin ray. Anal and caudal fin margins largely continuous, but separated distally by small notch.

Pelvic fin short, distal margin convex, middle fin rays longest. Pelvic fin located entirely anterior to vertical through middle of SL, with its origin along vertical through middle portion of base of dorsal fin. Tip of adpressed pelvic fin falling slightly short of anal-fin origin. Medial most pelvic-fin ray with membranous attachment to body for basal one-fourth to one-third of its length.

Pectoral-fin length approximately one-half of HL. Pectoral-fin margin very slightly convex, with middle fin rays longest. First pectoral-fin ray spinous, but flexible distally and without either serrations or distal filament.

Coloration in alcohol. Dark pigmentation on head and lateral surface of abdomen largely in form of scattered, stellate, dark chromatophores of approximately size of eye when fully expanded but with chromatophores constricted in many specimens (e.g., Fig. 52). Chromatophores on posterior region of body noticeably smaller. Body light brown in specimens with fully-expanded chromatophores and creamy white with fine, brown spots in specimens with contracted chromatophores. Caudal region with dark chromatophores evenly distributed other than for denser concentration of spots along dorsal midline and along base of caudal fin. Chromatophores less concentrated above base of anal fin and on ventrolateral surface of abdomen. Humeral region of body with more densely concentrated patch of dark chromatophores forming diffuse, triangular blotch extending posteriorly in some individuals as far as length of adpressed pectoral fin. Dorsal and lateral surfaces of nape, snout, and dorsal portion of head as far ventrally as horizontal extending through orbit with few, scattered, dark chromatophores. Remainder of head and abdomen with few, if any, widely-scattered, dark chromatophores.

Dorsal fin with dark spot no larger than size of eye located on base of two anterior fin rays. Pectoral, pelvic, and anal fins lacking dark chromatophores. Caudal fin dusky, with small, dark chromatophores scattered irregularly along both margins of fin rays.

Barbels unpigmented or with few, dark chromatophores basally.

Sexual dimorphism. The limited available sample of Denticetopsis sauli does not demonstrate the sexual dimorphism of the pectoral, dorsal, and anal fins that is present in many species within the Cetopsinae, albeit not in the other species of Denticetopsis.

Distribution. Denticetopsis sauli is only know from the río Pamoni in the río Casiquiare basin of the upper río Negro system of Venezuela (Fig. 46).

Remarks. The largest available specimen, $21 \mathrm{~mm} \mathrm{SL}$, is a mature male (Ferraris, 1996: 167).

Material examined. 7 specimens (17-21.0 mm SL). Venezuela. Amazonas: outflow stream from a series of morichales (palm swamps), approximately $5 \mathrm{~km}$ from mouth of río Pamoni, río Casiquiare basin $\left(2^{\circ} 48^{\prime} \mathrm{N}, 65^{\circ} 53^{\prime} \mathrm{W}\right)$, MBUCV V-20300, 1 (20.5, holotype of Denticetopsis sauli); MBUCV V-20301, 2 (20-21; paratypes of Denticetopsis sauli); ANSP 161432, 4 (17-21; paratypes of Denticetopsis sauli; 2 specimens, 20-21 mm, cleared and stained).

\section{Denticetopsis seducta, new species}

Figs. 46, 53, Tables 16-22

Diagnosis. Denticetopsis seducta is distinguished from $D$. royeroi and $D$. sauli by the combination of the lack of elongate, symphyseal teeth on the dentary, a reduced lateral line extending posteriorly on the body beyond the abdomen onto 


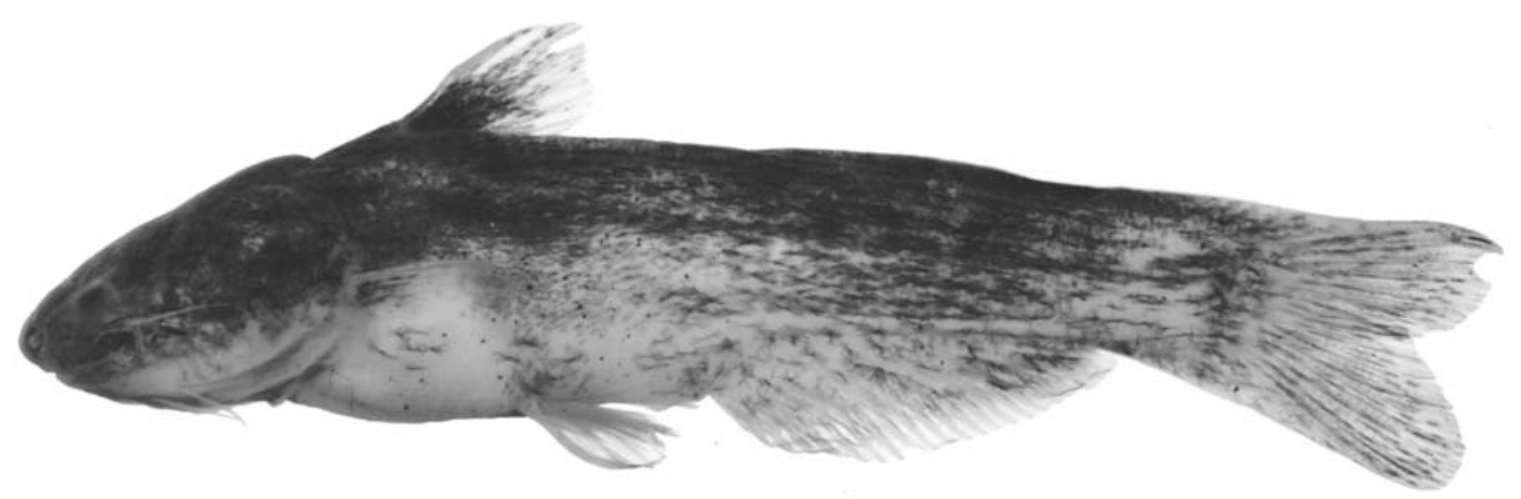

Fig. 53. Denticetopsis seducta, new species, holotype, ANSP 178466, 39 mm SL; Peru, Loreto, Caño “Sabolito," small creek on terra firma approximately $25 \mathrm{mi}(=40 \mathrm{~km})$ south of Iquitos $\left(4^{\circ} 14^{\prime} 45^{\prime \prime} \mathrm{S}, 7^{\circ} 24^{\prime} 57^{\prime \prime} \mathrm{W}\right)$.

at least the caudal peduncle, the presence of dentition on the vomer, a dorsal fin with 5 or 6 segmented rays and with the first ray that is spinous basally, a symmetrical, shallowlyforked caudal fin, and the possession of horizontally-elongate, dark, stellate chromatophores when the chromatophores are expanded. Denticetopsis seducta differs from D. epa in the relative position of the origin of the anal fin (located distinctly anterior of vertical through middle of TL versus approximately at vertical through middle of TL, respectively) and the relative depth of the caudal peduncle versus the length of the caudal peduncle (depth/length 1.33-1.5 versus 1.15-1.3, respectively). Denticetopsis seducta differs from $D$. macilenta in the position of the middle of the orbit (located at anterior $0.25-0.27$ of HL versus $0.18-0.19$ of HL, respectively) and in the relative width of the head (head width/HL 0.61-0.70 versus, 0.77-0.84, respectively). Denticetopsis seducta differs from $D$. praecox in the number of premaxillary tooth rows (three rows of teeth present in all but smallest examined specimens versus two rows of teeth present at all body sizes, respectively), in the pigmentation of the caudal fin (without a distinct, pale region in the distal portions of the middle fin rays versus the presence of a distinct, pale region in the distal portions of the middle fin rays, respectively), and in the degree of pigmentation of the pectoral fin (heavily pigmented versus lightly pigmented, respectively). Denticetopsis seducta differs from D. iwokrama in the number of caudal (26 to 31 versus 32, respectively), preanal (14 to 17 with 17 in only 1 of 23 specimens examined for this feature versus 17, respectively), and total vertebrae (39 to 42 with a mode of 40 and 42 in only 1 of 31 specimens examined for this feature versus 43 , respectively) and in the pigmentation of the pectoral fin (heavily pigmented versus lightly pigmented, respectively).

Description. Body ranges from elongate to moderately deep depending on overall condition of individual; slightly-compressed laterally anteriorly and becoming progressively distinctly-compressed posteriorly. Body depth at dorsal-fin origin approximately $0.20-0.30$ of SL depending on overall condition of specimen. Lateral line on body complete, unbranched, and midlateral; extending from vertical through pectoral-fin base to onto caudal peduncle but falling to varying degrees short of posterior margin of hypural plate. Dorsal profile of body straight from nape to dorsal-fin origin and straight from dorsal-fin origin to caudal-fin base. Ventral profile of body convex along abdomen, approximately straight to slightly convex, but posterodorsally-slanted, along base of anal fin. Caudal-peduncle depth approximately one and one-third times caudal-peduncle length.

Head in profile acutely triangular overall with bluntlypointed snout. Dorsal profile of head slightly convex from tip of snout to nape. Ventral profile of head slightly convex. Margin of snout in dorsal view rounded. Postorbital margins of head running nearly in parallel from dorsal view. Enlarged jaw musculature very evident externally on dorsal surface of postorbital portion of head.

Opercular membrane attaching to isthmus only anterior of vertical through pectoral-fin insertion. Opercular opening moderate; extending ventral of pectoral-fin insertion by distance equal to distance from tip snout to posterior margin of orbit and extending dorsal of pectoral-fin insertion by distance equal to diameter of eye.

Eye situated on lateral surface of head; located entirely dorsal to horizontal extending through pectoral-fin insertion; eye visible in dorsal view, but not in ventral view, of head. Middle of orbit at approximately anterior one-fourth of HL. Eye diameter approximately one-half of snout length. Interorbital width slightly greater than distance from tip of snout to middle of eye. Anterior narial opening circular, surrounded by short, anteriorly-directed, tubular rim of skin. Opening of anterior nares located along horizontal extending through maxillary-barbel origin and ventral of horizontal extending through tip of snout. Distance between anterior nares approximately equal to distance from tip of snout to middle of eye. Posterior narial opening located on dorsal surface of head, situated along vertical through anterior margin of orbit; narial opening nearly round and completely surrounded by flap of skin of nearly uniform height with posterior margins of flap in contact.

Mouth inferior; its width approximately one-half of HL. Margin of lower jaw gently rounded, its posterior limit reaching to vertical through posterior margin of orbit. Premaxillary tooth patch in form of gently-arched band continuous across 
midline and with anterior margin convex and posterior margin concave and running in parallel to anterior margin. Teeth on premaxilla small, conical, sharply-pointed, and arranged in two, regular rows of uniform-sized teeth across premaxilla, with variable number of teeth anterior of those two series; anterior teeth irregular in smaller individuals and forming third irregular row in larger specimens. Vomerine teeth arranged in single, arched row with small gap in tooth series at midline. Vomerine teeth stout, conical, and become progressively larger laterally, with even smallest teeth in series larger than teeth on premaxilla. Dentary teeth comparable in shape to, but larger in size than, premaxillary teeth. Dentary dentition consisting of three or four irregular rows medially that taper to one row laterally.

Maxillary barbel slender, its length approximately equal to distance from tip of snout to rear of eye, and approximately one-third to one-half of HL; barbel origin located ventral to middle of orbit. Medial mental barbel slightly shorter than lateral mental barbel, with latter approximately equal in length to maxillary barbel. Medial mental-barbel origin located along vertical through rictus. Lateral mental-barbel origin situated slightly posterior of vertical through medial mental-barbel origin. Tips of adpressed mental barbel falling short of posterior margin of opercle.

Dorsal fin moderately large overall with length of its base approximately 0.29-0.32 of HL. Length of longest branched dorsal-fin ray equal to approximately one-half of HL. Dorsalfin spinelet absent. First dorsal-fin ray spinous for basal onehalf of length but flexible more distally, and without distal filament present in some species within Cetopsinae. Distal margin of dorsal fin convex, with second branched ray longest. Dorsal-fin origin located at anterior $0.33-0.35$ of SL and along vertical extending through middle of adpressed pectoral fin. Tip of adpressed dorsal fin reaching vertical through vent. Posterior most dorsal-fin ray without posterior, membranous attachment to caudal peduncle.

Caudal fin shallowly-forked, symmetrical; tips of lobes rounded. Length of longest caudal-fin ray approximately 1.5 times length of middle fin rays.

Base of anal fin moderately long. Anal-fin origin located distinctly posterior of middle of SL but falling distinctly short of middle of TL. Anal-fin margin slightly convex in all examined specimens. Membranous attachment present between posterior margin of basal one-half of posterior most anal-fin ray and caudal peduncle.

Pelvic fin moderate; distal margin slightly convex with middle fin rays longest. Pelvic-fin insertion located anterior to middle of SL and along vertical through posterior terminus of base of dorsal fin. Tip of adpressed pelvic fin extending past middle of SL to at least anterior, but not posterior, margin of vent. Medial most pelvic-fin ray with membranous attachment to body along basal one-fourth of its length.

Pectoral-fin length approximately one-half of HL. Pectoral-fin margin distinctly convex with middle ray longest. First pectoral-fin ray spinous with smooth margins, spinous portion of ray proportionally short with length approximately one-half that of first branched fin ray.

Coloration in alcohol. Overall coloration of head and body medium-brown to nearly black and somewhat, to distinctly, darker dorsally. Abdomen pale. Dark coloration primarily formed of large, stellate, horizontally-elongate, dark chromatophores when chromatophores expanded. Body also with few, scattered, discrete, dark spots. Head dark dorsally, with dark pigmentation continuing ventrally as far as horizontal extending through pectoral-fin insertion. Amount of pigmentation in transition zone between dark and light areas on side of head highly variable. Head pale ventrally with little or no pigmentation around lower lip.

Dorsal fin dark for basal one-half except for pale anterior and posterior most rays; distal one-half of remainder of fin pale overall but with scattered, dusky pigmentation. Anal fin dusky basally, becoming progressively paler distally. Caudal fin dusky with pigmentation somewhat more pronounced basally in some individuals but uniformly dusky in other specimens. Pelvic fin pale. Pectoral fin ranging from dusky to dark within available population samples.

Maxillary barbel with dusky, basal pigmentation and pale distally. Mental barbels pale.

Sexual dimorphism. The examined specimens of Denticetopsis seducta do not demonstrate the sexual dimorphism of the anal, dorsal, and pectoral fins that is present in many species of the Cetopsinae, albeit not in the other species of Denticetopsis.

Distribution. Denticetopsis seducta has a relatively wide, albeit scattered, distribution in the central and western portions of the Amazon basin and possibly the southwestern portions of the río Orinoco basin (Fig. 46; see also "Remarks" below).

Etymology. The species name, seducta, from the Latin for remote or apart, is in reference to the disjunct distribution of this species relative to the other members of Denticetopsis.

Remarks. The type series of Denticetopsis seducta that originated in the río Ucayali basin and in the region of Iquitos in northeastern Peru, and the non-type population samples of the species from the rio Aripuanã in the rio Madeira basin, Brazil agree in all examined features. A single specimen that originated in the upper río Napo in eastern Ecuador (ANSP 139105) and which is tentatively identified as Denticetopsis seducta has slightly higher number of total vertebrae (43) than the 39 to 42 total vertebrae that occur in the other examined specimens assigned herein to that species (datum of that specimen not included in Tables 16 to 22). Additional population samples of Denticetopsis from the upper río Napo basin are necessary to determine whether this specimen represents yet another undescribed species.

A single specimen from the southwestern portions of the río Orinoco basin in Colombia (ANSP 139573) which would 
Table 16. Number of specimens of the species of Denticetopsis with cited number of dorsal and pectoral-fin rays. Bold indicates value for holotype when examined.

\begin{tabular}{|c|c|c|c|c|c|c|c|}
\hline & \multicolumn{4}{|c|}{ Dorsal-fin Rays } & \multicolumn{3}{|c|}{ Pectoral-fin Rays } \\
\hline & 3 & 4 & 5 & 6 & 6 & 7 & 8 \\
\hline D. ера & & & & 15 & 1 & 11 & 2 \\
\hline D. iwokrama & & & & 1 & & 1 & \\
\hline D. macilenta & & & 3 & 4 & & 5 & 1 \\
\hline D. praecox & & & 2 & 17 & & 9 & 1 \\
\hline D. royeroi & & 1 & & & & 1 & \\
\hline D. sauli & 1 & 4 & & & 1 & 1 & \\
\hline D. seducta & & & 6 & 27 & & 29 & 1 \\
\hline
\end{tabular}

Table 17. Number of specimens of the species of Denticetopsis with cited number of branched anal-fin rays. Bold indicates value for holotype when examined. None of anal-fin rays are branched in Denticetopsis royeroi and D. sauli.

\begin{tabular}{lccccccc}
\hline & \multicolumn{7}{c}{ Branched Anal-fin Rays } \\
& 19 & 20 & 21 & 22 & 23 & 24 & 25 \\
\hline D. epa & 3 & $\mathbf{5}$ & 4 & 2 & & & \\
D. iwokrama & & & & & $\mathbf{1}$ & & \\
D. macilenta & 1 & - & 2 & 2 & & & \\
D. praecox & & & 4 & 5 & - & - & 1 \\
D. royeroi & - & - & - & - & - & - & - \\
D. sauli & - & - & - & - & - & - & - \\
D. seducta & & 1 & 1 & 1 & $\mathbf{4}$ & 1 & \\
\hline
\end{tabular}

Table 18. Number of specimens of the species of Denticetopsis with cited number of total anal-fin rays. Bold indicates value for holotype when examined.

\begin{tabular}{lccccccccc}
\hline & \multicolumn{10}{c}{ Total Anal-fin Rays } \\
& 24 & 25 & 26 & 27 & 28 & 29 & 30 & 31 & 32 \\
\hline D. epa & & $\mathbf{6}$ & 4 & 5 & & & & & \\
D. iwokrama & & & & & & $\mathbf{1}$ & & & \\
D. macilenta & 1 & - & 3 & 1 & 1 & $\mathbf{1}$ & & & \\
D. praecox & & 2 & $\mathbf{4}$ & 7 & 3 & 2 & & & \\
D. royeroi & & & & & & & & $\mathbf{1}$ & \\
D. sauli & 2 & 1 & 11 & 15 & 6 & $\mathbf{5}$ & 1 & & $\mathbf{1}$ \\
D. seducta & 2 & 1 & &
\end{tabular}

Table 19. Number of specimens of the species of Denticetopsis with cited number of preanal vertebrae. Bold indicates values for holotype when available. Value for $D$. royeroi, known only from holotype which could not be radiographed, unavailable.

\begin{tabular}{|c|c|c|c|c|c|c|}
\hline & \multicolumn{6}{|c|}{ Preanal Vertebrae } \\
\hline & 12 & 13 & 14 & 15 & 16 & 17 \\
\hline$\overline{D . e p a}$ & & & 8 & 7 & & \\
\hline D. iwokrama & & & & & & 1 \\
\hline D. macilenta & & & 3 & 2 & 2 & \\
\hline D. praecox & & & 4 & 13 & & \\
\hline D. sauli & 1 & 1 & & & & \\
\hline D. seducta & & & 10 & 16 & 5 & 1 \\
\hline
\end{tabular}

represent the only record of the species from outside the Amazon basin, may also be $D$. seducta. A definitive identification of that population must, however, await the availability of larger population samples of that form from that portion of the río Orinoco system.

Given the uncertainty as the identification of the single specimens from both the upper río Napo and the western río
Table 20. Number of specimens of the species of Denticetopsis with cited number of precaudal vertebrae. Bold indicates values for holotype when available. Value for D. royeroi, known only from holotype which could not be radiographed, unavailable.

\begin{tabular}{lcccc}
\hline & \multicolumn{5}{c}{ Precaudal Vertebrae } \\
& 11 & 12 & 13 & 14 \\
\hline D. epa & $\mathbf{1}$ & 13 & 1 & \\
D. iwokrama & $\mathbf{1}$ & & & \\
D. macilenta & $\mathbf{2}$ & 3 & 2 & \\
D. praecox & 4 & $\mathbf{1 4}$ & & \\
D. sauli & 2 & & & \\
D. seducta & 5 & $\mathbf{2 3}$ & 4 & 2 \\
\hline
\end{tabular}

Table 21. Number of specimens of the species of Denticetopsis with cited number of caudal vertebrae. Bold indicates value for holotype when available for this study. Value for $D$. royeroi, known only from holotype which could not be radiographed, unavailable.

\begin{tabular}{lccccccc}
\hline & \multicolumn{7}{c}{ Caudal Vertebrae } \\
& 26 & 27 & 28 & 29 & 30 & 31 & 32 \\
\hline D. epa & 2 & $\mathbf{5}$ & 8 & & & & \\
D. iwokrama & & & & & & & $\mathbf{1}$ \\
D. macilenta & & & 3 & 3 & $\mathbf{1}$ & & \\
D. praecox & & $\mathbf{5}$ & 6 & 5 & 2 & & \\
D. sauli & & & 1 & - & 1 & & \\
D. seducta & 4 & 2 & $\mathbf{1 7}$ & 9 & 1 & 1 & \\
\hline
\end{tabular}

Table 22. Number of specimens of species of Denticetopsis with cited number of total vertebrae. Bold indicates value for holotype when examined. Value for $D$. royeroi, known only from holotype which could not be radiographed, unavailable.

\begin{tabular}{lcccccc}
\hline & \multicolumn{5}{c}{ Total Vertebrae } \\
& 38 & 39 & 40 & 41 & 42 & 43 \\
\hline D. epa & 2 & 5 & 8 & & & \\
D. iwokrama & & & & & & $\mathbf{1}$ \\
D. macilenta & & 2 & $\mathbf{5}$ & & & \\
D. praecox & 1 & $\mathbf{6}$ & 7 & 4 & & \\
D. sauli & & 1 & - & 1 & & \\
D. seducta & & 3 & $\mathbf{2 2}$ & 8 & 1 & \\
\hline
\end{tabular}

Orinoco basin, those localities are not plotted on Fig. 46.

Material examined. 39 specimens (39, 20-51 mm SL). Holotype. Peru. Loreto: Caño "Sabalito," small creek on terra firma approximately $25 \mathrm{mi}(=\mathrm{km}) \mathrm{S}$ of Iquitos (414'45"S, 73²4'57"W), M. H. Sabaj et al., 11 August 2001, ANSP 178466, 1 (39). Paratypes. 11 specimens (11, 20-51 mm SL). Peru. Loreto: Caño “Sabalito," small creek on terra firma approximately $25 \mathrm{mi}(=40 \mathrm{~km}) \mathrm{S}$ of Iquitos (414'45"S, 7324'57"W), collected with holotype, ANSP 179141, 2 (20-46); MUSM 20297, 2 (26-32); USNM 372758, 1, (36). Río Ucayali drainage, Quebrada Copal, at km 15 on road from Jenaro Herrera to Colonia Angamos, S. Kullander et al., 29 August 1983, NRM 18387, 3 (33-40). Ecuador. Sucumbios: tributary to río Cuyabeno, about $10 \mathrm{~km} \mathrm{~N}$ of Marian and $1 \mathrm{~km} \mathrm{~S}$ of río Cuyabeno $\left(0^{\circ} 1^{\prime} 59\right.$ "S, 76²0'0"W), D. J. Stewart et al., 30 Nov 1983, FMNH 111689,3 (30-51). Non-type specimens. 30 specimens (26-39 $\mathrm{mm}$ SL). Brazil. Amazonas: Igarapé Açu, $7 \mathrm{~km}$ below Santo Antonio do Iça, left bank of rio Solimões ( $\left.3^{\circ} 05^{\prime} \mathrm{S}, 67^{\circ} 57^{\prime} \mathrm{W}\right)$, MZUSP 23545, 1 (39). Mato Grosso: Igarapé Ingazeiro, $20 \mathrm{~km}$ above mouth of rio Canumã of rio Aripuanã, below Dardanelos, MZUSP 37813 , 27 (26-31.5; 5 specimens, $27-38 \mathrm{~mm}$, cleared and stained). 


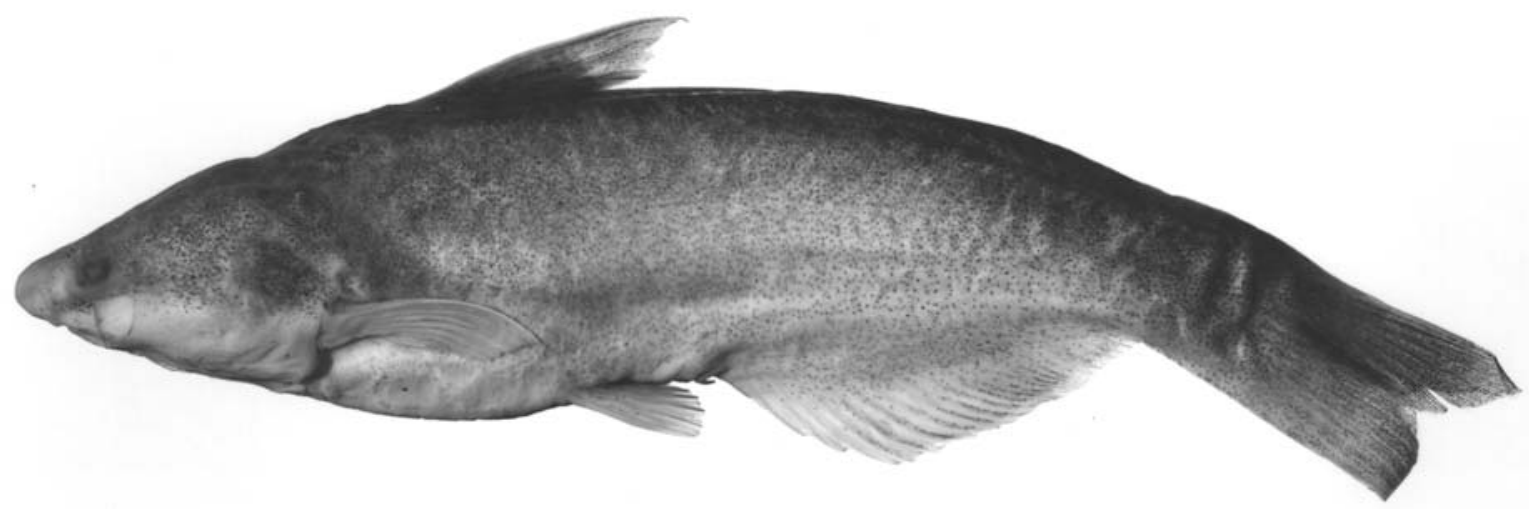

Fig. 54. Paracetopsis atahualpa, new species, holotype, MUSM 11560, 128 mm SL; Peru, Tumbes, río Tumbes, Cabo Inga ( $\left.3^{\circ} 58^{\prime} 00^{\prime \prime} \mathrm{S}, 80^{\circ} 24^{\prime} 59^{\prime \prime} \mathrm{W}\right)$.

The following specimens may also be Denticetopsis seducta (see "Remarks" above): Colombia. Meta: Caño Emma, Finca El Viento $33.5 \mathrm{~km}$ NE of Puerto Lopez (río Orinoco basin; approximately $\left.4^{\circ} 08^{\prime} \mathrm{N}, 7^{\circ} 39^{\prime} \mathrm{W}\right)$, ANSP 139573, 1 (31.0). Ecuador. Napo: Small stream approximately 1 mile $(=1.6 \mathrm{~km})$ up río Payamino from its mouth at Puerto Coca (=Puerto Francisco de Orellana), ANSP 139105, 1 (30).

\section{Genus Paracetopsis Bleeker, 1862}

Paracetopsis Bleeker, 1862b: 16 [type species: Paracetopsis bleekeri, Bleeker, 1862, by original designation; Gender Feminine].

Paracetopsis Eigenmann \& Bean, 1907: 615 [type species: Cetopsis occidentalis, Steindachner, 1880, by original designation; Gender Feminine; preoccupied by Paracetopsis Bleeker, 1862 and replaced by Cetopsogiton Eigenmann \& Bean, in Eigenmann, 1910].

Cetopsogiton Eigenmann \& Bean, in Eigenmann, 1910: 398 [type species: Cetopsis occidentalis, Steindachner, by being a replacement name; Gender Masculine; replacement for Paracetopsis Eigenmann \& Bean, 1907 preoccupied by Paracetopsis Bleeker, 1862]

Diagnosis. Paracetopsis can be distinguished from all other genera in the Cetopsinae by the combination of the possession of a vomerine tooth patch with two or more rows of teeth and a medial gap between the contralateral components of the tooth patch.

Remarks. Paracetopsis bleekeri was published by Bleeker (1862b) in a paper within which Bleeker listed the generic name as Paracetopsis Guich [=Guichenot]. There is no indication that Paracetopsis was ever published by Guichenot (see Eschmeyer, 1998) and, thus, both the generic and species names must be credited to Bleeker.

Paracetopsis Eigenmann \& Bean (1907) is preoccupied by Paracetopsis Bleeker (1862). The replacement name, Cetopsogiton, that was proposed by Eigenmann \& Bean (in Eigenmann, 1910) has as its type species Cetopsis occiden- talis, a species whose holotype is also the neotype of the type species of Paracetopsis Bleeker. As a consequence of the type species of the two nominal genera sharing the same name-bearing type, Cetopsogiton is an objective junior synonym of Paracetopsis Bleeker (1862) (International Commission on Zoological Nomenclature, 1999: 64; Article 61.3.3).

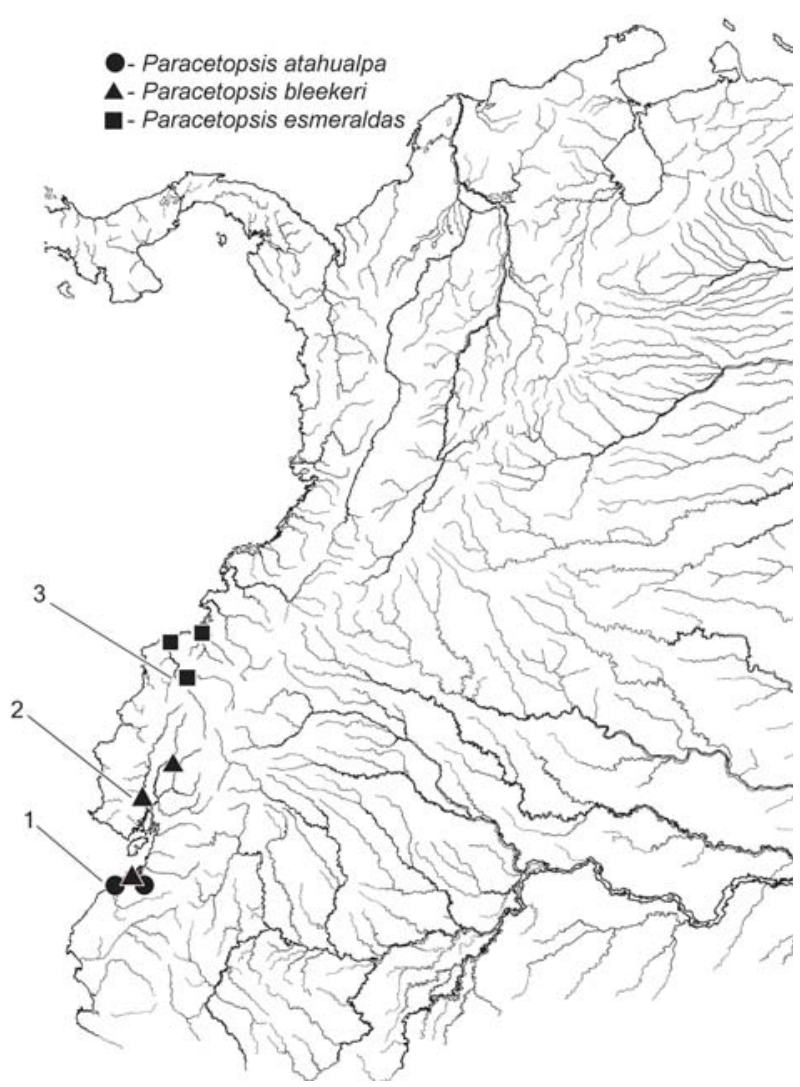

Fig. 55. Map of northwestern South America showing geographic distribution of Paracetopsis atahualpa $(1=$ holotype locality), Paracetopsis bleekeri ( 2 = neotype locality; also holotype locality for Cetopsis occidentalis), and Paracetopsis esmeraldas ( 3 = holotype locality) (some symbols represent more that one locality and/or lot of specimens). 


\section{Paracetopsis atahualpa, new species}

Figs. 54-55, Tables 23-29

Paracetopsis bleekeri [not of Bleeker, 1862].-Chang \& Ortega, 1995: 4 [Peru, Tumbes].

Diagnosis. Paracetopsis atahualpa is distinguished from all other species in the Cetopsinae with the exception of $P$. bleekeri and $P$. esmeraldas by the combination of the possession of a vomerine tooth patch with more than one row of teeth and a medial separation of the contralateral components of the patch. Paracetopsis atahualpa differs from P. bleekeri in the relative length of the pelvic fin (completely overlapping the vent versus falling short of the vent, respectively), the pigmentation pattern on the operculum (the possession of a distinct patch of dark pigmentation versus the lack of such pigmentation, respectively), in overall body pigmentation (dark versus light, respectively), in the extent of the medial gap in the vomerine tooth patch (with a limited medial gap between the contralateral components of the tooth patch equivalent to the width of one or two vomerine teeth versus with a distinct medial gap equivalent to the width of three of four vomerine teeth, respectively), and to a degree in the number of total vertebrae (50 versus 47 to 50 with 49 most common and 50 in only 1 of 21 radiographed specimens, respectively). Paracetopsis atahualpa differs from $P$. esmeraldas in the dorsal profile of the body at the area of contact of the posterodorsal portion of the externally apparent jaw musculature with the anterior portion of the epaxial musculature (with distinct notch versus smooth continuous profile, respectively), the degree of pigmentation of the basal portion of the maxillary barbel (distinctly dark versus pale or with few scattered, dark chromatophores, respectively), and to a degree in the number of caudal vertebrae (36 to 38 with 37 most common versus 37 to 40 with 38 most common, respectively; see Table 28) and number of total vertebrae (50 versus 50 to 53 with 51 most common, respectively; see Table 29).

Description. Body relatively elongate, slightly-compressed anteriorly and becoming distinctly-compressed posteriorly. Body depth at dorsal-fin origin approximately 0.26 of SL, and approximately equal to distance from anterior margin of orbit to posterior margin of opercle. Lateral line on body complete and midlateral; extending from vertical through pectoral-fin base to hypural plate with short, dorsal bend on hypural plate. Portion of lateral line on caudal peduncle with few short, ventrally-directed branches. Dorsal profile of body slightly convex from nape to dorsal-fin origin, straight from dorsal-fin origin to caudal-fin base. Distinct notch in body profile obvious in lateral view between posterodorsal margin of externally apparent jaw musculature and anterior margin of epaxial musculature. Ventral profile of body convex along abdomen, approximately straight, but posterodorsally-slanted along base of anal fin. Caudal-peduncle depth approximately equal to caudal-peduncle length.
Head in profile acutely triangular with bluntly-rounded snout. Dorsal profile of head nearly straight from tip of snout to nape. Ventral profile of head slightly convex. Profile of snout from dorsal view obtusely triangular overall, but rounded anteriorly. Postorbital margins of head aligned nearly in parallel from dorsal view. Enlarged jaw musculature slightly evident externally on dorsal surface of postorbital portion of head.

Opercular membrane attaching to isthmus only anterior to vertical through pectoral-fin insertion. Opercular opening large; extending ventral of pectoral-fin insertion by distance equal to distance from tip of snout to middle of orbit and extending dorsal of pectoral-fin insertion by distance equal to snout length.

Eye situated on lateral surface of head; located entirely dorsal to horizontal extending through pectoral-fin insertion; eye visible in dorsal view, but not in ventral view of head. Middle of orbit at approximately anterior one-fourth of HL. Eye diameter approximately equal to one-half of snout length. Interorbital width approximately equal to distance from tip of snout to posterior margin of orbit. Anterior narial opening circular, surrounded by short, anteriorly-directed, tubular rim of skin. Opening of anterior nares located ventral of horizontal extending through tip of snout and along horizontal extending through maxillary-barbel origin. Distance between anterior nares approximately equal to distance from tip of snout to middle of eye. Posterior narial opening situated on dorsal surface of head, located along vertical through anterior margin of orbit; opening nearly round and nearly completely surrounded by flap of skin, with anterior portion highest and with narrow gap posteriorly between margins of flap.

Mouth inferior; its width approximately one-half of HL. Margin of lower jaw gently rounded; its posterior border reaching to vertical through posterior margin of orbit. Premaxillary tooth patch in form of gently-arched band. Band of teeth continuous across midline with anterior margin convex and posterior margin concave and running in parallel to anterior margin. Teeth on premaxilla small, conical, sharply-pointed, and arranged in four regular rows. Vomerine teeth arranged in contralateral tooth patches located on each side of midline, with patches obliquely-aligned and separated at midline by distance equivalent to width of one or two vomerine teeth. Vomerine teeth similar in form and size to those on premaxilla, with one row medially and two rows laterally. Dentary teeth comparable in size and shape to premaxillary teeth. Dentary dentition consisting of four tooth rows medially that taper to two rows laterally.

Maxillary barbel slender, its length approximately equal to distance from tip of snout to posterior margin of orbit. Maxillary-barbel origin located ventral to middle of orbit. Mental barbels approximately equal in length to maxillary barbel and to each other. Medial mental-barbel origin located at vertical through rictus. Lateral mental-barbel origin situated only slightly posterior to medial mental-barbel origin. Tips of adpressed mental barbels falling short of posterior margin of opercle. 
Dorsal-fin size moderate overall with length of dorsal-fin base approximately $0.39-0.40$ of HL. Longest dorsal-fin ray, excluding distal filament, equal in length to slightly less than two-thirds of HL. Dorsal-fin spinelet absent. First dorsal-fin ray not spinous and with short, distal filament in all available, apparently male, specimens. Distal margin of dorsal fin straight, with first ray longest. Dorsal-fin origin located at approximately anterior 0.30 of SL and along vertical extending through middle of adpressed pectoral fin. Tip of adpressed dorsal fin falling slightly short of vertical through tip of adpressed pelvic fin but reaching to vertical through vent. Posterior most dorsal-fin ray without posterior, membranous attachment to body.

Caudal fin deeply-forked, symmetrical; tips of lobes slightly rounded. Length of longest caudal-fin ray approximately two times length of middle fin rays.

Base of anal fin comparatively long. Anal-fin origin located well posterior of middle of SL. Anal-fin margin distinctly convex along entire length in all available, apparently male, specimens. Posterior most unbranched and anterior two-thirds of branched anal-fin rays of nearly equal length, with subsequent fin rays becoming gradually shorter. Posterior most anal-fin ray without posterior, membranous attachment to body.

Pelvic fin comparatively long, its distal margin nearly straight, with first branched ray longest. Pelvic-fin insertion located distinctly anterior of middle of SL and along vertical through posterior portion of base of dorsal fin. Tip of adpressed pelvic fin extending posterior of middle of SL and nearly to anal-fin origin. Medial most pelvic-fin ray with membranous attachment to body for basal two-thirds of its length.

Pectoral-fin length approximately two-thirds of HL. Pectoral-fin margin very slightly concave anteriorly and then convex along rest of margin, with first ray longest. First pectoral-fin ray not spinous but with very short distal filament in all available, apparently male, specimens.

Coloration in alcohol. Head and body with scattered, dark pigmentation over dorsal and lateral surfaces with overall coloration somewhat darker dorsally. Abdomen and underside of head and snout without dark pigmentation. Blotch of darker pigmentation present on lateral surface of body located in area immediately posterior of opercle and dorsal to basal one-half of adpressed pectoral fin. Sides of head with distinct boundary between dorsal pigmented and ventral unpigmented regions, boundary extending from horizontal extending through base of maxillary barbel posteriorly to base of operculum. Posterior margin of opercle sparsely pigmented.

Dorsal fin covered with scattered, dark spots; fin more intensely pigmented on basal one-half and along entire length of membrane between first and second fin rays. Anal fin with scattered, dark pigmentation on basal portions of fin rays and interradial membranes, but with margin of fin clear. Caudal fin dusky throughout. Pectoral fin with scattered, dark pigmentation on basal one-half of dorsal surface but lacking dark pigmentation on ventral surface. Pelvic fin with sparse, scattered, dark pigmentation basally.
All barbels with scattered, small, dark spots of pigmentation basally and otherwise pale.

Sexual dimorphism. All available specimens of Paracetopsis atahualpa are apparently mature males as evidenced by the distal filaments on the first fin rays of the dorsal and anal fins and in the convex margin of the anal fin. These features are characteristic of mature males in those species of the Cetopsinae that demonstrate sexual dimorphism.

Distribution. Paracetopsis atahualpa is only known from the Pacific Ocean versant río Tumbes basin in northwestern Peru and the adjoining upper reaches of the río Zarumilla basin in southwestern Ecuador (Fig. 55).

Etymology. The species name, atahualpa, is in reference to Atahualpa who reigned from 1515 to 1533 as the last ruler of the Inca Empire that encompassed the region from which the population samples of this species originated.

Remarks. Chang \& Ortega (1995: 4) reported Paracetopsis bleekeri from Tumbes Department of northwestern Peru. This record was presumably based on the examination of MUSM 5507 and MUSM 5508, the only specimens of the species then available to those authors. Examination of those specimens reveals that they are rather $P$. atahualpa, a very similar species that, nonetheless, differs from $P$. bleekeri on the basis of the features cited in the "Diagnosis".

Material examined. 7 specimens (128-242 mm SL). Holotype.

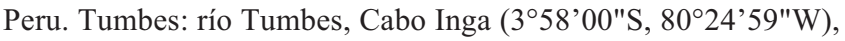
M. Napravnik et al., 8 January 1997, MUSM 11560, 1 (128). Paratypes. Peru. Tumbes: río Tumbes, Cabo Inga ( $3^{\circ} 58^{\prime} 00^{\prime \prime S}$, $\left.80^{\circ} 24^{\prime} 59^{\prime \prime} \mathrm{W}\right)$, collected with holotype, MUSM 16360, 2 (145148), USNM 361717, 1 (153). Cabo Inga, río Tumbes at its

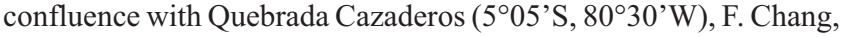
10 December 1993, MUSM 5508, 1 (242). Río Tumbes, no specific locality, H. Gutierrez, MUSM 5507, 16 November 1978, 1 (210). Ecuador. El Oro: Portovelo (approximately $3^{\circ} 43^{\prime} \mathrm{S}, 7^{\circ} 37^{\prime} \mathrm{W}$, apparently upper portions of río Zarumilla system), J. N. Rose, 13 October 1918, USNM 83530, 1 (155).

\section{Paracetopsis bleekeri Bleeker, 1862}

Figs. 55-56, Tables 23-29

Paracetopsis bleekeri Bleeker, 1862b: 16 [type locality unstated; herein interpreted as río Guayas or río Santa Rosa basins, southwestern Ecuador; herein restricted to Guayaquil by neotype designation].-Schultz, 1944: 251 [as valid].-Vari \& Ferraris, 2003: 258 [in check list; synonymy, distribution, common names].-[not Chang \& Ortega, 1995: 4].

Cetopsis ventralis Gill, 1870: 95 [type locality: Maranon or Upper Amazon, and Napo Rivers; herein interpreted as río Guayas or río Santa Rosa basins, southwestern Ecuador, see under "Remarks" concerning type locality].Eigenmann \& Eigenmann, 1888: 157 [listing]; 1890: 322 
[listing]; 1891: 36 [listing].-Boulenger, 1898b: 9 [comparison with Cetopsis macroteronema].-Fowler, 1941: 472 [Peru, río Marañon].-1945: 70 [Peru, río Marañon].Ferraris and Vari, 1992: 16 [holotype repository].-Vari and Ferraris, 2003: 258 [as synonym of Paracetopsis bleekeri Bleeker].

Cetopsis occidentalis Steindachner, 1880: 100 [48 of offprint], pl. 8, fig. 2 [type locality: (Ecuador) Guayaquil].Eigenmann and Eigenmann, 1888: 157 [listing].-1890: 322 [listing]; 1891: 36 [listing].-Eigenmann and Bean, 1907: 665 [as type species of Paracetopsis].-Schultz, 1944: 251 [treated as synonym of Paracetopsis bleekeri].-Vari and Ferraris, 2003: 258 [as synonym of Paracetopsis bleekeri Bleeker].

Cetopsis (Pseudocetopsis) occidentalis.-Steindachner, 1902: 136 [Ecuador, Guayaquil, río de Bodegas].

Paracetopsis occidentalis.-Eigenmann \& Bean, 1907: 665 [designation of species as type species of Paracetopsis].Eigenmann, 1920a: 13 [Guayaquil basin].

Pseudocetopsis ventralis.-Eigenmann, 1910: 398 [erroneously cited as present in Maranon].-Eigenmann \& Allen, 1942: 149 ["known only from Orton's specimens"].-Schultz, 1944: 252 [in key to species of Pseudocetopsis].-Gosline, 1945: 55 [listing].-Fowler, 1954: 5 [erroneously cited as present in Alto Amazonas, Peru].-Burgess, 1989: 292 [erroneously cited as present in (río) Maranon and upper (río) Napo].-Evers \& Seidel, 2002: 741 [listing].-[Not Ortega \& Vari, 1986: 15].

Cetopsogiton occidentalis.-Eigenmann, 1910: 398 [(Ecuador) Guayaquil].-Eigenmann, 1921: 514 [(Ecuador) Guayas]; 1923: 56 [Guayaquil market].-Gosline, 1945: 55 [listing].Ovchynnyk, 1967: 35 [Ecuador: río Daule, Province Guayas; río Vinces, near Vinces].-1968: 255 [Ecuador: río Daule, Province Guayas; río Vinces, near Vinces].-Burgess, 1989: 292 [rivers near Guayaquil (Ecuador)].

Cetopsigoton occidentalis.-Barriga, 1991: 56 [generic name misspelled; Ecuador, Piso Tropical y Subtropical Oriental].

Diagnosis. Paracetopsis bleekeri is distinguished from all other species in the Cetopsinae with the exception of $P$. atahualpa and $P$. esmeraldas by the combination of the possession of a vomerine tooth patch with more than one row of teeth and a medial separation of the contralateral components of the patch. Paracetopsis bleekeri differs from P. atahualpa in the relative length of the pelvic fin (tip of fin falling short of the vent versus completely overlapping the vent, respectively), in the pigmentation on the operculum (lacking an opercular pigmentation patch versus having a distinct patch of dark opercular pigmentation, respectively), the overall coloration of the head and body (light versus dark, respectively), the extent of the medial gap in the vomerine tooth patch (with a distinct medial gap between the contralateral components of the tooth patch equivalent to the width of three or four vomerine teeth versus with a limited medial gap equivalent to the width of one or two vomerine teeth, respectively), and to a degree in the number of total vertebrae (50 in all specimens versus 47 to 50 with 49 most common and 50 in only 1 of 21 radiographed specimens, respectively; Table 29). Paracetopsis bleekeri differs from $P$. esmeraldas in the pigmentation on the operculum (lacking an opercular pigmentation patch versus having a distinct patch of dark opercular pigmentation, respectively), in the extent of the medial gap in the vomerine tooth patch (separated by a distinct medial gap between the contralateral components of the tooth patch equivalent to the width of three or four vomerine teeth versus a limited gap equivalent to the width of one or two vomerine teeth, respectively), and in the mode and to a degree in the range of the caudal vertebrae ( 34 to 38 with 36 most common versus 37 to 40 with 38 most common, respectively; Table 28).

Description. Body relatively elongate, slightly-compressed laterally anteriorly and becoming progressively distinctlycompressed posteriorly. Body depth at dorsal-fin origin approximately $0.22-0.24$ of SL, and approximately equal to distance from anterior margin of orbit to posterior margin of opercle. Lateral line on body complete, unbranched, and midlateral; extending from vertical through pectoral-fin base to hypural plate with short, dorsal bend on hypural plate. Portion of lateral line on caudal peduncle with few, short, ventrally-directed branches. Dorsal profile of body straight from nape to dorsal-fin origin and slightly convex from dorsal-fin origin to caudal-fin base. Distinct notch in dorsal profile of body obvious from lateral view between posterodorsal margin of externally apparent enlarged jaw musculature and anterodorsal margin of epaxial musculature. Ventral profile of body convex along abdomen, approximately straight, but posterodorsally-slanted, along base of anal fin. Caudal-peduncle depth approximately equal to caudal-peduncle length.

Head in profile acutely triangular overall with bluntlyrounded snout. Dorsal profile of head slightly convex from tip of snout to vertical through anterior margin of orbit and straight from that point to nape. Ventral profile of head slightly convex. Margin of snout from dorsal view obtusely triangular overall and rounded anteriorly. Postorbital margins of head running nearly in parallel from dorsal view. Enlarged jaw musculature slightly evident externally on dorsal surface of postorbital portion of head.

Opercular membrane attaching to isthmus only anterior of vertical through pectoral-fin insertion. Opercular opening large; extending ventral of pectoral-fin insertion by distance equal to distance from tip of snout to posterior margin of orbit and extending dorsal of pectoral-fin insertion by distance equal to snout length.

Eye situated on lateral surface of head; located entirely dorsal to horizontal extending through pectoral-fin insertion; eye visible in dorsal view, but not in ventral view of head. Middle of orbit at approximately anterior one-fourth of HL. Eye diameter approximately equal to one-half of snout length. Interorbital width approximately equal to distance from tip of snout to posterior margin of orbit; narial openings relatively small compared to that in other species of the Cetopsinae. 


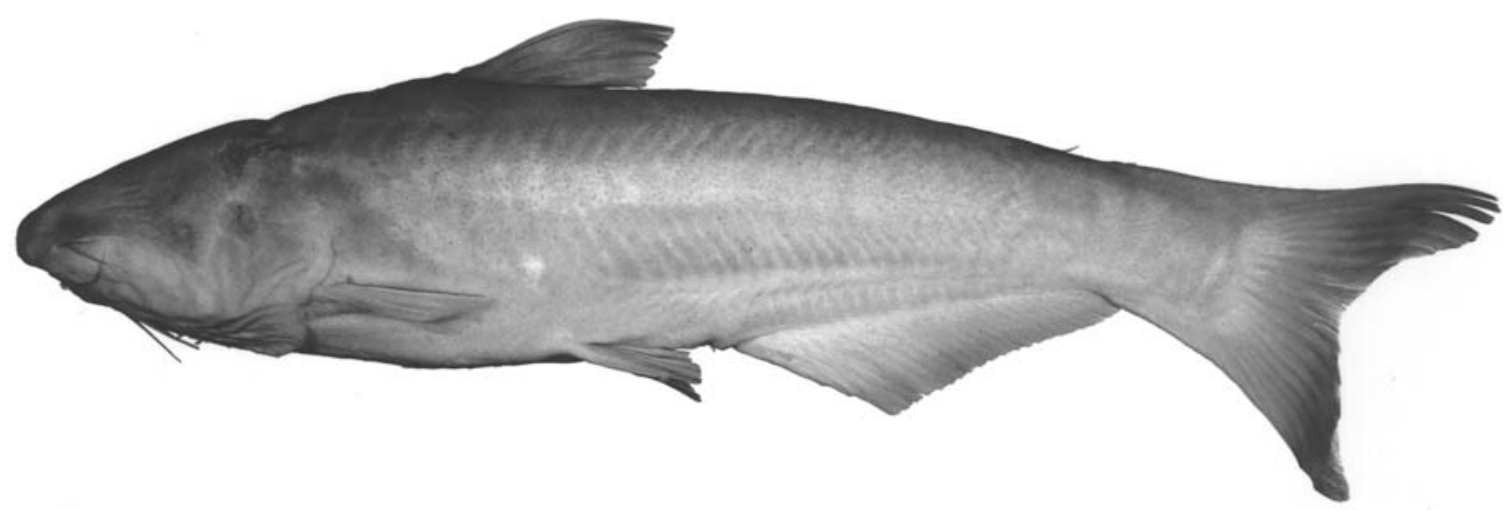

Fig. 56. Paracetopsis bleekeri, ZMH 12211, 158 mm SL; Ecuador, Guayas, Guayaquil ( $\left.2^{\circ} 10^{\circ} \mathrm{S}, 79^{\circ} 54^{\prime} \mathrm{W}\right)$.

Anterior narial opening circular, surrounded by short, anteriorly-directed, tubular rim of skin. Opening of anterior nares located along horizontal extending through both tip of snout and maxillary-barbel origin. Distance between anterior nares approximately equal to distance from tip of snout to middle of eye. Posterior narial opening located on dorsal surface of head, situated along vertical through anterior margin of orbit; narial opening approximately round and nearly completely surrounded by flap of skin, with anterior portion highest and narrow gap posteriorly between margins of flap.

Mouth inferior; its width approximately one-half of HL. Margin of lower jaw gently rounded, its posterior limit reaching to vertical situated slightly posterior of posterior margin of orbit. Premaxillary tooth patch in form of gently-arched band, continuous across midline and with anterior margin convex and posterior margin concave and running in parallel to anterior margin. Teeth on premaxilla small, conical, and sharply-pointed, with teeth arranged in four rows; teeth arranged in distinct rows medially but irregularly-arranged laterally. Vomerine teeth arranged in distinct contralateral tooth patches to each side of midline. Tooth patches obliquelyaligned and separated medially by distance equivalent to width of three or four vomerine teeth. Vomerine teeth similar in form and size to those on premaxilla, with teeth in each patch arranged in one row medially and two rows laterally in smaller specimens and two complete rows with shorter third row laterally in larger individuals. Dentary teeth comparable in size and shape to premaxillary teeth. Dentary dentition consisting of four tooth rows medially that taper to two rows laterally.

Maxillary barbel slender, its length approximately equal to distance from tip of snout to posterior margin of orbit. Maxillary-barbel origin located ventral to middle of orbit. Mental barbels approximately equal in length to maxillary barbel and to each other. Medial mental-barbel origin located along vertical through rictus. Lateral mental-barbel origin situated posterior of vertical through middle of adpressed medial mental barbel. Tips of adpressed mental barbels falling short of base of branchiostegal rays.

Dorsal fin moderately large overall with length of dorsalfin base approximately $0.30-0.35$ of HL. Longest dorsal-fin ray equal in length to two-thirds of HL. Dorsal-fin spinelet absent. First dorsal-fin ray not spinous and lacking short, distal filament in immature males and apparent females, but with short filament present in single, apparently mature, male. Distal margin of dorsal fin straight, with first ray longest. Dorsalfin origin located at approximately anterior 0.40 of SL and along vertical extending through distal one-fourth of adpressed pectoral fin. Tip of adpressed dorsal fin reaching nearly to vertical through tip of adpressed pelvic fin. Posterior most dorsal-fin ray without posterior, membranous attachment to body.

Caudal fin moderately-forked, symmetrical; tips of lobes slightly rounded. Length of longest caudal-fin ray approximately one and three-fourths times length of middle fin rays.

Base of anal fin comparatively long. Anal-fin origin located distinctly posterior of middle of SL, and approximately along vertical through middle of TL. Anal-fin margin straight in females and immature males, with posterior most unbranched anal-fin ray longest and subsequent rays becoming gradually shorter. Anal-fin margin slightly convex in single apparently mature male. Posterior most anal-fin ray without posterior, membranous attachment to body.

Pelvic fin moderately long; distal margin nearly straight, with first ray longest. Pelvic-fin insertion located anterior to middle of SL and along vertical through posterior terminus of base of dorsal fin. Tip of adpressed pelvic fin extending beyond middle of SL and just reaching anterior limit of vent. Medial most pelvic-fin ray with membranous attachment to body along basal two-thirds of its length.

Pectoral-fin length approximately one-half of HL. Pectoral-fin margin very gently convex, with first ray longest. First pectoral-fin ray not spinous and without distal filament in immature males and apparent females, but with short, distal filament present in single, apparently mature, male.

Coloration in alcohol. Available specimens all faded and without any dark pigmentation obvious. Following description based on original illustration of Cetopsis occidentalis (herein considered a synonym of Paracetopsis bleekeri; see "Remarks") by Steindachner (1880, pl. 8, fig. 2). Head and body with scattered, dark pigmentation dorsally and laterally with 
underside of snout, abdomen, and ventral portions of region above anal-fin base paler.

Dorsal fin with basal dusky pigmentation and irregular dark spots distally. Anal fin dusky with distal margin pale.

Barbels apparently pale.

Sexual dimorphism. The single examined apparently mature male of Paracetopsis bleekeri has distinct, but short, distal filaments on first rays of the dorsal and pectoral fins contrary to conspecific females and immature males that lack those structures. Mature males also have a slightly convex anal-fin margin contrary to the straight margin to the fin in conspecific females and immature males.

Distribution. Paracetopsis bleekeri is only known from the Pacific Ocean versant río Guayas and río Santa Rosa basins of southwestern Ecuador (Fig. 55).

Remarks. Paracetopsis bleekeri was originally described by Bleeker (1862b: 16) based on an unstated number of specimens and without an indicated collecting locality. The type material of Paracetopsis bleekeri was examined by Bleeker in the "Mus. Paris" $[=\mathrm{MNHN}]$ and in his description of that species, Bleeker apparently utilized a manuscript name or jar label name originally proposed by Guichenot to whom he credited the species. Searches through the MNHN collections during this study failed to reveal the existence of any specimens that may have been the basis of the original description of $P$. bleekeri. The MNHN registers also do not document that any relevant specimens were ever catalogued into the holdings of that institution. The name Paracetopsis bleekeri was not used by subsequent authors for nearly eight decades until Schultz (1944: 251) recognized that this nominal species was the oldest available name for the species known until that time as Cetopsogiton occidentalis (Steindachner).

Notwithstanding the lack of a type series of Paracetopsis bleekeri, the original description of the species by Bleeker (1862b: 16) noted that the vomer in that species had a tooth patch with more than one row of teeth and with the tooth patch interrupted medially. This combination of features is only known to occur in three species within the Cetopsinae: $P$. bleekeri, a species that is only known to occur in tributaries of the Gulf of Guayaquil in southwestern Ecuador; $P$. atahualpa, a species endemic to the río Tumbes basin of northwestern Peru and upper portions of the río Zarumilla in southwestern Ecuador; and P. esmeraldas a species that is apparently endemic to the Pacific Ocean versant rivers of northwestern Ecuador. The two latter species are described as new in this paper.

Examination of the three species of Paracetopsis demonstrated that although the gap between the contralateral components of the vomerine tooth patch that was cited by Bleeker (1862b) in the description of P. bleekeri is general for all species in the genus, such a discontinuity in the tooth patch is, however, only readily apparent in the material herein considered to be $P$. bleekeri. It seems unlikely that the much smaller gap between the contralateral components of the vomerine tooth patch that is characteristic of $P$. atahualpa and $P$. esmeraldas would have been obvious to Bleeker fourteen decades ago in light of the limitations of the microscopes of the period.

Above and beyond such a supposition involving the sophistication of the optical equipment available to Bleeker, there is also a significantly greater likelihood that the specimen available to Bleeker originated in the río Guayas basin, the home of the form herein considered to be P. bleekeri. The río Guayas is the largest river basin on the Pacific Ocean versant of South America and has long had an active major seaport (Guayaquil) at is mouth. As a consequence, the río Guayas basin has been the source of specimens for museum collections for two centuries. The río Tumbes and río Zarumilla systems that are inhabited by $P$. atahualpa are, in contrast, much smaller and less accessible river systems than is the río Guayas, and both remain poorly sampled ichthyologically until the present time. Similarly the Pacific Ocean versant rivers of northwestern Ecuador that are inhabited by $P$. esmeraldas remained effectively terra incognita ichthyologically until the latter part of the nineteenth century (Orcés, 1967: 137), a considerable period after the original description of $P$. bleekeri. These considerations along with the details of vomerine dentition discussed above lead us to equate $P$. bleekeri with the populations of the Cetopsinae from the río Guayas basin that have been more typically identified as Cetopsogiton occidentalis.

Stabilization of the nomenclature of Paracetopsis bleekeri is necessary in light of the existence of two similar species in drainage systems located close to the range of $P$. bleekeri in the río Guayas and río Santa Rosa basins ( $P$. atahualpa, in the río Tumbes and río Zarumilla basins; and $P$. esmeraldas, in various river systems of northwestern Ecuador). We herein designate the holotype of Cetopsis occidentalis Steindachner (1880), NMW 47377, a species herein considered a junior synonym of Paracetopsis bleekeri (see discussion in following paragraph) as the neotype for Paracetopsis bleekeri.

Cetopsis occidentalis was described by Steindachner (1880: 99, pl. 8. figs. 2, 2a) based on a single female that was collected near Guayaquil, Ecuador, apparently in 1880 (H. Wellendorf, NMW; pers. commun., 2003). Although we have been unable to examine the holotype of C. occidentalis (NMW 47377), the detailed original description of the species and the accompanying figures, in conjunction with the fact that only a single species of Paracetopsis, and indeed the Cetopsinae, was found to be present within the series of specimens examined in this study that originated in the río Guayas, make it clear that $C$. occidentalis is equivalent to the form that is identified as Paracetopsis bleekeri herein.

Cetopsis ventralis was originally described in a publication (Gill, 1870: 95) that was based on a collection of fishes said, according to the title of that contribution, to have originated from the "Maranon or Upper Amazon, and Napo Rivers." In light of the title of Gill's publication, many subsequent authors assumed that all of the material cited in that 
report originated in the Amazon basin (see synonymy of Cetopsis ventralis at beginning of this species account). The introductory remarks to Gill's publication (1870: 92) noted, however, that the material was collected by Prof. Orton in an "expedition to the Andes of Ecquador [=Ecuador] and Peru and thence across the continent of South America." This geographically more encompassing description of the route of the collecting party raises the possibility that portions of the fish fauna of some Trans-Andean river systems may have been sampled during the early phases of the Orton expedition.

Our examination of the holotype of Cetopsis ventralis demonstrated that it cannot be differentiated from what is herein considered to be Paracetopsis bleekeri. Given that the known distribution of $P$. bleekeri is restricted to the $\mathrm{Pa}-$ cific Ocean slopes of southwestern Ecuador, the conspecificity of the two nominal species indicates that the holotype of Cetopsis ventralis must have originated from the western slopes of the Andean Cordillera rather than from within the Amazon basin as was assumed to be the case by prior authors. A comparable situation occurs with the indefinite type locality of "Peru" reported for Curimatus brevipes that was described by Eigenmann \& Ogle (1907: 3) on the basis of a specimen also collected by Orton, the collector of the holotype of Cetopsis ventralis. This inexact locality was subsequently interpreted by various authors (e.g., Eigenmann \& Allen, 1942: 299) to indicate that the holotype of Curimatus brevipes originated in the Amazon basin. Analysis demonstrated (Vari, 1989b: 19) that C. brevipes is rather conspecific with Pseudocurimata troschelii (Günther), a species endemic to the rivers of the Pacific versant of northwestern Peru and southeastern Ecuador, a distribution paralleling, in part, that of Paracetopsis bleekeri. On the basis of the evidence of the conspecificity of the holotype of Cetopsis ventralis with Paracetopsis bleekeri and in light of the non-specific locality information associated with the holotype, we herein restrict the type locality of Cetopsis ventralis to the río Guayas or río Santa Rosa basins of southwestern Ecuador.

Material examined. 45 specimens (94-246 mm SL). Ecuador. Guayas: Guayaquil market, CAS 77029, 7 (145-216); CAS 77030, 2 (172-183); CAS-SU 83331, 1 (242); USNM 76971, 5 (128-203, 1 specimen cleared and stained); MUSM 6680, 1 (180). $3 \mathrm{~km}$ out of Santo Domingo on road to Esmeraldas, FMNH 96446, 1 (123). El Oro: Gualtaco, río Santa Rosa, near mouth ( $\left.3^{\circ} 26^{\prime} \mathrm{S}, 80^{\circ} 11^{\prime} \mathrm{W}\right)$, USNM 163899, 1 (205). Guayas: Guayaquil (2॰10'S, 7954'W), AMNH 5353SW, 1; CAS-SU 22751, 1 (204); CAS-SU 69689, 1 (164); CAS-SU 9303, 1 (168); MCZ 30965, 2 (183-183); USNM 53519, 1 (128); ZMH 12207, 1 (177); ZMH 12208, 5 (151-193); ZMH 12209, 1 (226), ZMH 12210, 1 (230); ZMH 12211, 1 (158). río Guayas basin, tributary of río Baba, Puerto Ila $\left(0^{\circ} 31\right.$ " $45^{\prime} \mathrm{S}$, 79²1"03'W), MEPN 1719, 1 (196). Unspecific locality, MNHN B-0279, 2 (183-246).

Questionable locality: "Maranon or Upper Amazon, and Napo Rivers" (=río Marañon and río Napo; stated locality incorrect, specimen probably originated in the río Guayas basin of western Ecuador, see "Remarks" above), USNM 8307, 1 (113; holotype of Cetopsis ventralis).
No locality information: USNM 304883, 5; MZUSP uncataloged, 1; AMNH 97234, 1 (94, specimen cleared and stained).

\section{Paracetopsis esmeraldas, new species}

Figs. 55, 57, Tables 23-29

Pseudocetopsis amphiloxa [not of Eigenmann].-Barriga, 1994b: 77, 80, 84 [Ecuador, río Esmeraldas; common name; habitat; not citation from Ecuador: río Mira, río Mataje, or río Santiago].

Diagnosis. Paracetopsis esmeraldas is distinguished from all other species in the Cetopsinae with the exception of $P$. bleekeri and $P$. atahualpa by the combination of the possession of a vomerine tooth patch with more than one row of teeth and a medial separation of the contralateral components of the patch. Paracetopsis esmeraldas differs from $P$. atahualpa and $P$. bleekeri to a notable degree in the number of total vertebrae (50 to 53 , with 22 of 26 radiographed specimens having 51 to 53, vertebrae versus 50 in P. atahualpa, and 47 to 50, with 50 in only 1 of 21 radiographed specimens in P. bleekeri). Paracetopsis esmeraldas further differs from $P$. atahualpa in the dorsal profile of the body at the rear of the head in the area of contact of the externally apparent posterodorsal portion of the jaw musculature and the anterior portion of the epaxial musculature (without distinct notch versus with distinct notch, respectively), the degree of pigmentation of the basal portion of the maxillary barbel (pale or with few scattered, dark chromatophores versus distinctly dark, respectively), and to a degree in the number of caudal vertebrae (37 to 40, with 38 most common, versus 36 to 38 , with 37 most common, respectively; see Table 28). Paracetopsis esmeraldas further differs from $P$. bleekeri in the extent of the medial gap in the vomerine tooth patch (separated by a limited gap between the contralateral components of the tooth patch equivalent to the width of one or two vomerine teeth versus separated by a distance equivalent to the width of three or four vomerine teeth, respectively), in the pigmentation on the lateral surface of the opercle (patch of dark pigmentation present versus absent, respectively), and in the mode and to a degree in the range of the number of caudal vertebrae (37 to 40, with 38 most common, in $P$. esmeraldas versus 34 to 38 , with 36 most common, in $P$. bleekeri, see Table 28).

Description. Body relatively elongate, slightly-compressed laterally anteriorly and becoming distinctly-compressed posteriorly. Body depth at dorsal-fin origin approximately $0.22-$ 0.24 of SL, and approximately equal to distance from anterior margin of orbit to posterior margin of opercle. Lateral line on body complete, unbranched, and midlateral; extending from vertical through pectoral-fin base to hypural plate with short, dorsal bend on hypural plate. Single available, large individual not demonstrating few, short, ventrally-directed branches of lateral line occurring in comparably-sized individuals of con- 


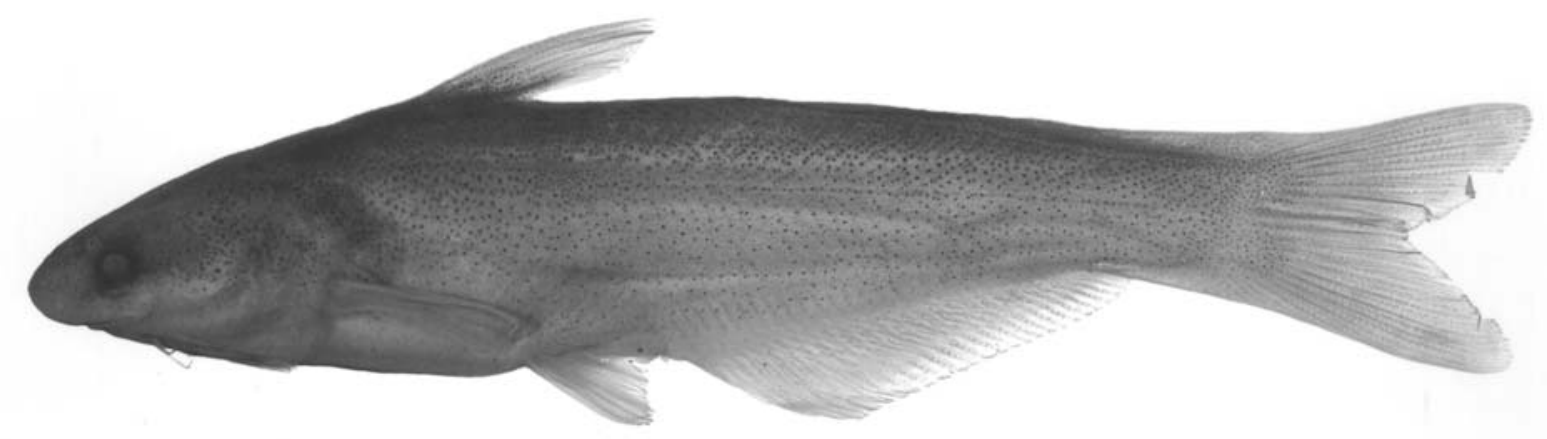

Fig. 57. Paracetopsis esmeraldas, new species, holotype, MCZ 48768, 68 mm SL; Ecuador, Esmeraldas, río Esmeraldas basin, río Blanco, $4 \mathrm{~km}$ above junction with río Quininde $\left(0^{\circ} 20^{\prime} \mathrm{N}, 79^{\circ} 28^{`} \mathrm{~W}\right)$.

generic species. Dorsal profile of body slightly convex from nape to dorsal-fin origin, straight from dorsal-fin origin to caudal-fin base. Ventral profile of body convex along abdomen, approximately straight, but posterodorsally-slanted along base of anal fin. Caudal-peduncle depth approximately equal to caudal-peduncle length.

Head in profile acutely triangular with bluntly-rounded snout. Dorsal profile of head convex from tip of snout to vertical through posterior nostril and nearly straight from that point to nape. Ventral profile of head nearly straight and slightly oblique. Profile of snout in dorsal view broadly rounded in smaller specimens, more triangular in largest examined individual. Postorbital margins of head running nearly in parallel from dorsal view. Enlarged jaw musculature not evident externally on dorsal surface of postorbital portion of head. No notch in dorsal profile obvious in lateral view between posterodorsal margin of externally obvious jaw musculature and anterior margin of epaxial musculature.

Opercular membrane attaching to isthmus only in region anterior to vertical through pectoral-fin insertion. Opercular opening large; extending ventral of pectoral-fin insertion by distance equal to that from tip of snout to posterior margin of orbit and extending dorsal of pectoral-fin insertion by distance equal to snout length.

Eye situated on lateral surface of head; located entirely dorsal to horizontal extending through pectoral-fin insertion; eye visible in dorsal view, but not in ventral view of head. Middle of orbit at approximately anterior one-fifth of HL in most specimens (55-145 mm SL), but at approximately anterior one-fourth of HL in largest examined specimen (188 mm $\mathrm{SL}$ ). Eye diameter approximately equal to one-half of snout length. Interorbital width approximately equal to distance from tip of snout to posterior margin of orbit. Anterior narial opening circular, surrounded by short, anteriorly-directed, tubular rim of skin. Opening of anterior nares located ventral of horizontal through tip of snout and at horizontal extending through maxillary-barbel origin. Distance between anterior nares approximately equal to distance from tip of snout to middle of eye. Posterior narial opening located on dorsal surface of head and along vertical through anterior margin of orbit; opening of posterior nares nearly round and almost completely surrounded by flap of skin, with anterior portion of flap highest and narrow gap between margins of flap posteriorly.

Mouth inferior; its width approximately one-half of HL. Margin of lower jaw gently rounded, its posterior limit reaching to vertical through posterior margin of orbit. Premaxillary tooth patch in form of gently-arched band continuous across midline, with anterior margin convex and posterior margin concave and running in parallel to anterior margin. Teeth on premaxilla small, conical, sharply-pointed, and arranged in four, regular rows in most examined specimens (55-145 mm $\mathrm{SL})$, but with five regular rows present in largest examined individual (188 $\mathrm{mm} \mathrm{SL}$ ). Vomerine teeth arranged in distinct, contralateral patches located to each side of midline, with patches obliquely-aligned and slightly separated medially by distance equivalent to width of one or two vomerine teeth. Vomerine teeth similar in form to, but distinctly larger than, those on premaxilla, with one row medially and second shorter row laterally in smaller specimens and with two complete rows medially and third shorter row laterally in larger individuals. Dentary teeth comparable in size and shape to premaxillary teeth. Dentary dentition consisting of four rows medially, that taper to two rows laterally.

Maxillary barbel slender, its length approximately equal to distance from tip of snout to middle of eye in most specimens (45-145 mm SL), approximately equal to snout length in single distinctly larger specimen (188 mm SL); barbel origin located ventral to middle of orbit. Mental barbels approximately equal in length to maxillary barbel and to each other. Medial mentalbarbel origin located along vertical through rictus of jaw. Lateral mental-barbel origin situated only slightly posterior to medial mental-barbel origin. Tips of adpressed mental barbels falling short of posterior margin of opercle.

Dorsal fin moderately large overall with length of dorsalfin base approximately $0.38-0.41$ of HL. Longest dorsal-fin ray equal in length to approximately three-fourths of HL in most examined specimens (45-145 mm SL), approximately two-thirds of HL in single, distinctly larger examined individual $(188 \mathrm{~mm}$ SL). Dorsal-fin spinelet absent. First dorsal-fin ray not spinous and without distal filament (see "Sexual Dimorphism" below). Distal margin of dorsal fin straight, with first ray longest. Dorsal-fin origin located at, or slightly short of, approximately anterior one-third of SL and along vertical extending through 
distal one-fourth of adpressed pectoral fin. Tip of adpressed dorsal fin falling slightly short of vertical through tip of adpressed pelvic fin but reaching vertical through anal-fin origin. Posterior most dorsal-fin ray without posterior, membranous attachment to body.

Caudal fin moderately-forked, symmetrical; tips of lobes slightly rounded. Length of longest caudal-fin ray approximately two times length of middle fin rays in most examined specimens, approximately 1.5 times length of middle fin rays in single distinctly larger specimen.

Base of anal fin comparatively long. Anal-fin origin located slightly to distinctly posterior of middle of SL. Anal-fin margin straight along entire length (see "Sexual Dimorphism" below) with posterior most unbranched fin ray longest and subsequent fin rays becoming progressively shorter. Posterior most anal-fin ray without posterior, membranous attachment to body.

Pelvic fin moderately long. Distal margin of pelvic fin nearly straight, with first branched ray longest. Pelvic-fin insertion located distinctly anterior to middle of SL and slightly posterior of vertical through posterior terminus of base of dorsal fin. Tip of adpressed pelvic fin extending beyond middle of SL; reaching slightly posterior of vent and nearly to anal-fin origin in specimens of smaller and moderate sizes, but reaching only to middle of vent in single, distinctly larger examined individual. Medial most pelvic-fin ray with membranous attachment to body for basal two-thirds of its length.

Pectoral-fin length approximately two-thirds of HL. Pectoral-fin margin very slightly concave laterally and then convex medially, with first ray longest. First pectoral-fin ray not spinous and without short, distal filament (see "Sexual Dimorphism" below).

Coloration in alcohol. Head and body with scattered, dark pigmentation dorsally and laterally, with overall coloration somewhat darker dorsally. Abdomen and underside of head and snout lack dark pigmentation. Blotch of darker pigmentation located on body immediately posterior of opercle and dorsal to basal one-half of adpressed pectoral fin. Lateral surface of head with distinct boundary between dorsal pigmented and ventral unpigmented regions; boundary extending from level of maxillary barbel posteriorly to base of operculum; boundary distinct in specimens of 55 to $145 \mathrm{~mm} \mathrm{SL}$, but obscured in single, distinctly larger examined specimen (188 mm SL). Lateral surface of opercle with variably distinct, dark blotch. Blotch more obvious in smaller specimens and located entirely dorsal of horizontal extending through pectoral-fin insertion (blotch not readily apparent in photograph of specimen, Fig. 56); blotch obscure in single, examined individual of distinctly larger body size. Posterior margin of opercle only lightly pigmented.

Dorsal fin covered with scattered, dark pigmentation; pigmentation slightly darker basally but not forming more intensely-pigmented region. Anal fin with scattered, poorlydeveloped, dark pigmentation on basal two-thirds and with margin of fin clear in specimens of smaller to moderate size, but fin pale overall in single, distinctly larger examined individual. Caudal fin dusky throughout. Pectoral fin with scattered, dark pigmentation on basal one-half of dorsal surface but lacking dark pigmentation on ventral surface. Pelvic fin with few, widely-scattered spots of dark pigmentation basally.

Maxillary barbel with scattered, dark pigmentation basally. Mental barbels without dark pigmentation.

Sexual dimorphism. Apparently none of the available specimens of Paracetopsis esmeraldas is a sexually mature male. This limitation renders it impossible to determine whether this species demonstrates the sexual dimorphism in the anal, pectoral, and dorsal fins that is present in the other species of Paracetopsis and many other species of the Cetopsinae.

Remarks. Barriga (1994b: 80) reported Pseudocetopsis amphiloxa from the río Esmeraldas, río Santiago, río Mataje, and río Mira of the Pacific Ocean versant of northwestern Ecuador. All examined samples of the Cetopsinae from the río Esmeraldas system are Paracetopsis esmeraldas and we consequently consider reports of the occurrence of Pseudocetopsis amphiloxa from that river basin to be based on material of Paracetopsis esmeraldas. In contrast, the examined samples of the Cetopsinae from the río Santiago that presumably were, at least in part, the basis for the citation of Pseudocetopsis amphiloxa by Barriga (1994b) are the Cetopsis amphiloxa of this study (see listing of specimens under "Material examined" for C. amphiloxa). Paracetopsis esmeraldas does, however, occur in that river basin as evidenced by one examined specimen (CAS 162438) that originated in the río Santiago system. Although we have not examined the samples of the Cetopsinae from the río Mataje and río Mira that were identified by Barriga (1994b: 80) as $C$. amphiloxa, both of those river systems lie within the known range of that species, but beyond the limits of the known distribution of Paracetopsis esmeraldas. We tentatively conclude that the members of the Cetopsinae present in the río Mataje and río Mira systems are C. amphiloxa rather than Paracetopsis esmeraldas.

Distribution. Paracetopsis esmeraldas occurs in the Pacific Ocean versant rivers of northwestern Ecuador (Fig. 55).

Etymology. The species name, esmeraldas, is in reference to both the Ecuadorian Province of Esmeraldas from which all specimens of the species originated and to the río Esmeraldas basin within which the type series of the species was collected.

Common Name. Ecuador: “Ciego” (Barriga, 1994b: 77).

Ecology. Barriga (1994b: 80) reported that Paracetopsis esmeraldas (cited therein as Pseudocetopsis amphiloxa) is a freshwater species common to varying degrees within the río Esmeraldas basin. 
Table 23. Number of specimens of the species of Paracetopsis with cited number of dorsal and pectoral-fin rays. Bold indicates value for holotype when examined.

\begin{tabular}{lcccccc}
\hline & \multicolumn{3}{c}{ Dorsal-fin Rays } & \multicolumn{3}{c}{ Pectoral-fin Rays } \\
& 5 & 6 & 7 & 8 & 9 & 10 \\
\hline P. atahualpa & & $\mathbf{5}$ & & & $\mathbf{5}$ & \\
P. bleekeri & & 21 & & 2 & 18 & \\
P. esmeraldas & & $\mathbf{2 9}$ & 1 & $\mathbf{2 6}$ & 2 \\
\hline
\end{tabular}

Table 24. Number of specimens of the species of Paracetopsis with cited number of branched anal-fin rays. Bold indicates value for holotype when examined.

\begin{tabular}{lccccc}
\hline & \multicolumn{5}{c}{ Branched Anal-fin Rays } \\
& 23 & 24 & 25 & 26 & 27 \\
\hline P. atahualpa & 2 & 2 & $\mathbf{1}$ & & \\
P. bleekeri & 1 & 4 & 7 & 7 & 2 \\
P. esmeraldas & 2 & 12 & $\mathbf{9}$ & 6 & \\
\hline
\end{tabular}

Table 25. Number of specimens of the species of Paracetopsis with cited number of total anal-fin rays. Bold indicates value for holotype when examined.

\begin{tabular}{lcccccc}
\hline & \multicolumn{7}{c}{ Total anal-fin rays } \\
& 28 & 29 & 30 & 31 & 32 & 33 \\
\hline P. atahualpa & 1 & - & $\mathbf{3}$ & 1 & & \\
P. bleekeri & 1 & 4 & 5 & 8 & 2 & 1 \\
P. esmeraldas & 1 & 5 & 11 & $\mathbf{9}$ & 3 & \\
\hline
\end{tabular}

Table 26. Number of specimens of the species of Paracetopsis with cited number of preanal vertebrae. Bold indicates values for holotype when examined.

\begin{tabular}{lrrrrrr}
\hline & \multicolumn{7}{c}{ Preanal Vertebrae } \\
& 16 & 17 & 18 & 19 & 20 & 21 \\
\hline P. atahualpa & & $\mathbf{2}$ & 2 & 1 & & \\
P. bleekeri & 2 & 3 & 16 & & & \\
P. esmeraldas & & & $\mathbf{6}$ & 16 & 5 & 2 \\
\hline
\end{tabular}

Table 27. Number of specimens of the species of Paracetopsis with cited number of precaudal vertebrae. Bold indicates values for holotype when examined.

\begin{tabular}{lccccc}
\hline & \multicolumn{5}{c}{ Precaudal Vertebrae } \\
& 11 & 12 & 13 & 14 & 15 \\
\hline P. atahualpa & & 1 & $\mathbf{3}$ & 1 & \\
P. bleekeri & 1 & 6 & 12 & 1 & 1 \\
P. esmeraldas & & 3 & 12 & $\mathbf{1 3}$ & 1 \\
\hline
\end{tabular}

Table 28. Number of specimens of the species of Paracetopsis with cited number of caudal vertebrae. Bold indicates value for holotype when examined.

\begin{tabular}{lccccccc}
\hline & \multicolumn{7}{c}{ Caudal Vertebrae } \\
& 34 & 35 & 36 & 37 & 38 & 39 & 40 \\
\hline P. atahualpa & & & 1 & $\mathbf{3}$ & 1 & & \\
P. bleekeri & 2 & 4 & 11 & 3 & 1 & & \\
P. esmeraldas & & & & $\mathbf{1 2}$ & 13 & 1 & 3 \\
\hline
\end{tabular}

Table 29. Number of specimens of species of Paracetopsis with cited number of total vertebrae. Bold indicates value for holotype when examined.

\begin{tabular}{lccccccc}
\hline & \multicolumn{8}{c}{ Total Vertebrae } \\
& 47 & 48 & 49 & 50 & 51 & 52 & 53 \\
\hline P. atahualpa & & & & $\mathbf{5}$ & & & \\
P. bleekeri & 2 & 5 & 13 & 1 & & & \\
P. esmeraldas & & & & 4 & $\mathbf{1 2}$ & 9 & 1 \\
\hline
\end{tabular}

Material examined. 32 specimens (55-188 mm SL). Holotype. Ecuador. Esmeraldas: río Blanco, $4 \mathrm{~km}$ above junction with río Quininde $\left(0^{\circ} 20^{\prime} \mathrm{N}, 7^{\circ} 28^{\prime} \mathrm{W}\right.$; río Esmeraldas basin), collected 20 October 1971, MCZ 48768, 1 (68). Paratypes. 31 specimens (55$188 \mathrm{~mm} \mathrm{SL}$ ). Ecuador. Esmeraldas: río Blanco, $4 \mathrm{~km}$ above junction with río Quininde $\left(0^{\circ} 20^{\prime} \mathrm{N}, 79^{\circ} 28^{\prime} \mathrm{W}\right.$; río Esmeraldas basin), collected with holotype, MCZ 162749, 10 (49-90); USNM 372749, 3 (61-72), MEPN 1530, 3 (62-81). Río Esmeraldas, $35 \mathrm{~km}$ upstream of Esmeraldas (059’ N, 7942’W), 21 Oct 1971, MCZ 48769, 10 (68-88); MCZ 48770, 1 (145); MZUSP 22328, 3 (2, 55-67; 1 specimen, $58 \mathrm{~mm}$, cleared and stained). Lower río Santiago or pools and marshes near village of Borbon (latter locality at $1^{\circ} 04^{\prime} \mathrm{N}, 78^{\circ} 59^{\prime} \mathrm{W}$ ) at less than 10 m elevation, M. Olalla, August 1951, CAS 162438, 1 (188).

\section{Acknowledgments}

Research, collecting efforts, and museum studies in Peru, Venezuela, and Brazil associated with this study were supported by the Neotropical Lowland Research Program of the National Museum of Natural History, Smithsonian Institution, the All Catfish Species Inventory (NSF DEB-0315963), and the Conselho Nacional de Desenvolvimento Científico e Tecnológico, Brazilian Federal Government (CNPq). Support for the completion of the paper was provided by the Herbert R. and Evelyn Axelrod Chair in Systematic Ichthyology in the Division of Fishes of the National Museum of Natural History, Smithsonian Institution.

The successful completion of this project was made possible by the assistance of individuals who arranged for the loan and exchange of specimens, provided diverse forms of information, hospitality during visits, and myriad other types of assistance. We thank Melanie L. J. Stiassny and Barbara Brown (AMNH); John G. Lundberg, Dominique D. Dagit, Mark H. Sabaj, and William G. Saul (ANSP); Jonathan W. Armbruster (AUM); Darrell J. Siebert and Sean Davidson (BMNH); David Catania (CAS); Soraya Barrera (CBF); Barry Chernoff, Mary Anne Rogers, and Kevin Swagle (FMNH); José Iván Mojica (ICN-MHN), Larry M. Page, Mark H. Sabaj, and Michael E. Retzer (INHS); Walter Gill Morlis (ITAIPU); Christine Thacker, Jeffrey Siegel, and Richard Feeney (LACM); Ricardo M. C. Castro and Flávio A. Bockmann (LIRP); Francisco Provenzano (MBUCV); Donald C. Taphorn (MCNG), Carlos A. Lucena, Roberto E. Reis, and Luiz R. Malabarba (MCP); Karsten E. Hartel (MCZ); Ramiro Barriga (MEPN); Claude Weber and Sonia Fisch-Muller (MHNG); Jean-Claude Hureau, Philippe Keith, and Patrice Pruvost (MNHN); Paulo A. Buckup (MNRJ); Hernán Ortega and the late Fonchii Chang (MUSM); José L. de Figueiredo, Osvaldo T. Oyakawa, and Flávio C. T. Lima (MZUSP); Jan Mol and Paul Ouboter (NZCS); Ernst Mikschi and Helmut Wellendorf (NMW); Sven O. Kullander and Erik Åhlander (NRM); Erling Holm (ROM); Dean Hendrickson (TNHC); George H. Burgess (UF); Douglas W. Nelson (UMMZ), Hans-Joachim Paepke (ZMB); Horst Wilkens (ZMH), José Carlos de Oliveira (Universidade Federal de Juiz de Fora), Mônica Toledo-Piza Ragazzo (Universidade de São Paulo), and Michael Goulding (Amazon Conservation Alliance). 
Assistance at NMNH was provided by Shirleen S. Smith, Lisa Palmer, and in particular Sandra J. Raredon who provided numerous radiographs of examined specimens, assisted in the preparation of the maps, and in myriad other ways facilitated the completion of the project. The photographs of fishes in this paper were prepared by T. Britt Griswold and Sandra J. Raredon (NMNH). The paper benefited from the comments and suggestions of Michael E. Retzer (INHS) and Stanley H. Weitzman (NMNH).

\section{Literature Cited}

Agostinho, A. A. \& H. F. Júlio, Jr. 1999. Peixes da bacia do Alto rio Paraná, Pp. 375-400. In: R. H. Lowe-McConnell. Estudos ecológicos de comunidades de peixes tropicais. São Paulo, Brazil: Editora de Universidade de São Paulo.

Alonso de Arámburu, A., R. H. Arámburu \& R. A. Ringuelet. 1962. Peces paranensis nuevos para la fauna Argentina. Physis, 23(165): 223-238.

Apolinar-Maria, H. 1914. Especies nuevas. Peces descritos por el Señor Doctor Don C. H. Eigenmann. Boletin Sociedad de Ciencias Naturales, Instituto de LaSalle, 2(10): 278-279.

Barriga, R. 1991. Peces de agua dulce [Ecuador]. Politecnia, Organo Oficial de la Escuela Politecnia Nacional, 16(3): 7-88.

Barriga, R. 1994a. Peces del Parque Nacional Yasuni. Politecnia, Organo Oficial de la Escuela Politecnia Nacional, 19(2): 9-41.

Barriga, R. 1994b. Peces del Noroeste del Ecuador. Politecnia, Organo Oficial de la Escuela Politecnia Nacional, 19(2): 43-154.

Barthem, R. \& M. Goulding. 1997. The catfish connection. Ecology, migration and conservation of Amazon predators. New York: Colombia University Press, 144 p.

Baskin, J. E., T. M. Zaret \& F. Mago. 1980. Feeding of reportedly parasitic catfishes (Trichomycteridae and Cetopsidae) in the Rio Portuguesa Basin, Venezuela. Biotropica, 12(3): 182-186.

Bennemann, S. T., A. T. Silva-Souza \& G. R. A. Rocha. 1995. Composicion ictiofaunistica en cinco localidades de las cuenca del rio Tibage, PR - Brasil. Interciencia, 20(1): 7-13.

Bertoletti, J. J., C. A. S. de Lucena, Z. M. S. de Lucena, L. R. Malabarba \& R. E. dos Reis. 1989. Ictiofauna do rio Uruguai superior entre os municípios de Aratiba e Esmeralda, Rio Grande do Sul, Brasil. Comunicações do Museu de Ciências da PUCRS, (48-49): 3-42.

Bertoni, A. de W. 1939. Catálogos sistemáticos de los vertebrados del Paraguay. Revista de la Sociedad Cientifica del Paraguay, 4(4): 1-59.

Bichuette, M. E. \& E. Trajano. 2003. Epigean and subterranean ichthyofauna from the São Domingos karst area, upper Tocantins River basin, central Brazil. Journal of Fish Biology, 63: 1100-1121.

Bleeker, P. 1858. Ichthyologiae archipelagi indici prodromus. Vol. 1. Siluri. Bataviae: Lange and Co., 370 p.

Bleeker, P. 1862a. Notice sur les genres Trachelyopterichthys, Hemicetopsis et Pseudocetopsis. Verslagen en Mededeelingen der Koninklijke Akademie van Wetenschappen (Afdeeling Natuurkunde), Amsterdam, 14: 400-403.
Bleeker, P. 1862b. Atlas ichthyologique des Indes Orientales Néêrlandaises, publié sous les auspices du Gouvernement colonial néêrlandais. Tome II. Siluroïdes, Chacoïdes et Hétérobranchoïdes. Amsterdam: Frederic Muller et Co., 112 p., pls. 49-101.

Bleeker, P. 1863. Systema Silurorum revisum. Nederlandsch Tijdschrift voor de Dierkunde, Amsterdam, 1: 77-122.

Böhlke, E. B. 1984. Catalog of type specimens in the ichthyological collection of the Academy of Natural Sciences of Philadelphia. Academy of Natural Sciences of Philadelphia. Special Publication 14: i-viii + 1-246.

Boujard, T., F. J. Meunier, M. Pascal \& J. F. Cosson. 1990. Les Téléostéens d'un haut bassin fluvial Guyanais, l'Arataye. 2 Inventaires des "non-Characoïdes." Cybium, 14(4): 345-351.

Boujard, T., M. Pascal, J. F. Meunier \& P. Y. Le Bail. 1997. Poissons de Guyane. Guide écologique de l'Approuague et de la reserve des Nouragues. Paris: Institut National de la Recherche Agronomique. 219 p.

Boulenger, G. A. 1887. An account of the fishes collected by Mr. C. Buckley in eastern Ecuador. Proceedings of the Zoological Society of London, for 1887: 274-283, 4 pls.

Boulenger, G. A. 1897. On a collection of fishes from the island of Marajo, Brazil. Annals and Magazine of Natural History, series 20, 6: 294-299.

Boulenger, G. A. 1898a. On a collection of fishes from the rio Jurua, Brazil. Transactions of the Zoological Society of London, 14(7): 421-428, 4 pls.

Boulenger, G. A. 1898b. Viaggio del Dr. Enrico Festa nell' Ecuador e regioni vicine. Poissons de l'Équateur. Bolletino dei Musei di Zoologia ed Anatomia Comparata della R. Universita di Torino, 13(329): 1-13.

Braga, L. \& M. Azpelicueta. 1986 Adiciones a la ictiofauna Argentina en la provincia de Misiones (1). Historia Natural, 6(10): 85-89.

Britski, H. A. 1972. Peixes de agua doce do estado de São Paulo. Sistemática. In: Poluição e Piscicultura, Pp. 79-108. São Paulo, Brazil: Commissão Interestadual da Bacia Parana-Uruguai.

Britski, H. A., Y. Sato \& A. B. S. Rosa. 1984. Manual de identificação de peixes da região de Três Marias (com chaves de identificação para os peixes da bacia do São Francisco). Brasília, Brazil: Companhia de Desenvolvimento do Vale do São Francisco. 143 p.

Britski, H. A., Y. Sato \& A. B. S. Rosa. 1986. Manual de identificação de peixes da região de Três Marias (com chaves de identificação para os peixes da bacia do São Francisco). 2 ${ }^{\text {nd }}$ Edition. Brasília, Brazil: Companhia de Desenvolvimento do Vale do São Francisco. 115 p.

Britski, H. A., K. Z. de S. de Silomon \& B. S. Lopes. 1999. Peixes do Pantanal. Manual de identificação. Brasília, Brazil: Empresa Brasileira de Pesquisa Agropecuária. 184 p.

Burgess, W. E. 1989. An atlas of freshwater and marine catfishes. A preliminary survey of the Siluriformes. Neptune City, New Jersey, U. S. A., T. F. H. Publications, 784 p.

Cala, P. 1977. Los peces de la Orinoquia Colombiana: Lista preliminar anotada. Lozania (Acta Zoologica Colombiana), 24: 1-21. 
Cala, P. 1981. Catalogo de los ejemplares tipo en la coleccion de peces del Instituto de Ciencias Naturales - Museo de Historia Natural de la Universidad Nacional de Colombia. Lozania (Acta Zoologica Colombiana), 34: 1-8.

Cala, P. 1995. Trophic levels of the most abundant fishes of the Betania Reservoir, upper Rio Magdalena, Colombia. Acta Biologica Venezuelica, 16(1): 47-53.

Castello, H. P. 1969. Pimelodella griffini (Pisces, Pimelodidae), nueva cita para la fauna Argentina. Consideraciones acerca de la alimentacion, del sistema reproductor y de una papila urogenital en tres especies del genera Pimelodella. Physis, 28(77): 407-415.

Castro, D. M. \& A. L. Arboleda. 1988. Lista preliminar de los peces del río Caqueta, Colombia. Boletin Facultad de Biologia Marina, 8: 7-14.

Ceas, P. A. \& L. M. Page. 1996. Chaetostoma yurubiense (Teleostei: Siluriformes), a new species of loricariid catfish from the Aroa, Urama, and Yaracuy River systems in Venezuela. Copeia, 1993(3): 671-677.

Chang, F. 1998. Fishes of the Tambopata-Candamo Reserved Zone, southeastern Peru. Revista Peruana de Biologia, 5(1): 15-26.

Chang, F. \& H. Ortega. 1995. Additions and corrections to the list of freshwater fishes of Peru. Publicaciones del Museo de Historia Natural, Universidad Nacional Mayor de San Marcos, Series A. Zoologia, 50: 1-11.

Collette, B. B. 1982. South American freshwater needlefishes of the genus Potamorrhaphis (Beloniformes: Belonidae). Proceedings of the Biological Society of Washington, 95(4): 714-757.

Cope, E. D. 1872. On the fishes of the Ambiyacu River. Proceedings of the Academy of Natural Sciences of Philadelphia, for 1871: 250-294, 15 pls.

Cope, E. D. 1878. Synopsis of the fishes of the Peruvian Amazon, obtained by Professor Orton during his expeditions of 1873 and 1877. Proceedings of the American Philosophical Society, 17: 673-701.

Cuvier, G. 1829. Le Règne Animal, distribué d'après son organisation, pour servir de base á l'histoire naturelle des animaux et d'introduction á l'anatomie comparée. $2^{\text {nd }}$ edition, Volume 2. Paris, xviii $+532 \mathrm{p}$.

Cuvier, G. \& A. Valenciennes. 1840. Histoire naturelle des poissons, volume 14. Paris: Pitois-Levrault. 464 p., plates 389-420. [Date on volume 1839; actual publication date 1840].

Dahl, G. 1960a. Nematognathous fishes collected during the Macarena Expedition. Novedades Colombianas, 1(5): 302317.

Dahl, G. 1960b. New fresh-water fishes from western Colombia. Caldasia, 8(39): 451-484.

Dahl, G. 1964. Informe sobre la fauna acuatica del río Sinú. Bogotá: Corporacion Autonoma Regional de los Valles del Magdalena y del Sinú. 109 p.

Dahl, G. 1971. Los peces del norte de Colombia. Bogotá: Instituto de Desarrollo de los Recursos Naturales Renovables. 391 p.
Dahl, G., F. Medem \& A. R. Henao. 1963. El "Bocachico." Contribucion al estudio de su biologia y de su ambiente. Departamento de Pesca del Corporacion Autonoma regional de los Valles del Magdalena y del Sinú-CVM, 144 p.

Delsman, H. C. 1941. Résultats scientifiques des croisières du Navire-école Belge “Mercator”. III: Pisces. Mémoires du Musée Royal d'Histoire Naturelle de Belgique, series 2, 31:47-82.

Eigenmann, C. H. 1909. The freshwater fishes of Patagonia, and an examination of the Archiplata-Archelenis theory. Report of the Princeton University Expedition to Patagonia, 1896-1899, 3(1): 225-374.

Eigenmann, C. H. 1910. Catalogue of the freshwater fishes of tropical and south temperate America. Report of the Princeton University Expedition to Patagonia, 1896-1899, 3(4):375-511.

Eigenmann, C. H. 1912a. The freshwater fishes of British Guiana, including a study of the ecological grouping of species and the relation of the fauna of the plateau to that of the lowlands. Memoirs of the Carnegie Museum, 5: xii + 578 pages, 103 plates.

Eigenmann, C. H. 1912b. Some results of an ichthyological reconnaissance of Colombia, South America. Indiana University Studies, 10(8): 1-27.

Eigenmann, C. H. 1920a. South America west of the Maracaibo, Orinoco, Amazon, and Titicaca basins, and the horizontal distribution of its fresh-water fishes. Indiana University Studies, 7(45): 1-24.

Eigenmann, C. H. 1920b. The fishes of the rivers draining the western slope of the Cordillera Occidental of Colombia, Rios Atrato, San Juan, Dagua, and Patia. Indiana University Studies, 7(46): 1-19.

Eigenmann, C. H. 1920c. The Magdalena basin and the horizontal and vertical distribution of its fishes. Indiana University Studies, 7(47): 21-34.

Eigenmann, C. H. 1921. The nature and origin of the fishes of the Pacific slope of Ecuador, Peru and Chile. Proceedings of the American Philosophical Society, 60(4): 503-523.

Eigenmann, C. H. 1923. The fishes of western South America, Part 1: The fresh-water fishes of northwestern South America, including Colombia, Panama, and the Pacific slopes of Ecuador and Peru, together with an appendix upon the fishes of the Rio Meta in Colombia. Memoirs of the Carnegie Museum, 9: 1-346, 38 plates.

Eigenmann C. H. \& W. R. Allen. 1942. Fishes of western South America, I: The intercordilleran and Amazonian lowlands of Peru, II: The high Pampas, Bolivia, and northern Chile, with a revision of the Peruvian Gymnotidae, and of the genus Orestias. 494 pages. Lexington: University of Kentucky.

Eigenmann, C. H. \& B. A. Bean. 1907. An account of Amazon River fishes collected by J. B. Steere; with a note on Pimelodus clarias. Proceedings of the United Sates National Museum, 31(1503): 659-668.

Eigenmann, C. H. \& R. S. Eigenmann. 1888. Preliminary notes on South American Nematognathi. Proceedings of the California Academy of Sciences, series 2, 1: 119-172. 
Eigenmann, C. H. \& R. S. Eigenmann. 1890. A revision of the South American Nematognathi or cat-fishes. Occasional Papers of the California Academy of Sciences, 1: 1-508.

Eigenmann, C. H. \& R. S. Eigenmann. 1891. A catalogue of the fresh-water fishes of South America. Proceedings of the United States National Museum, 14: 1-81.

Eigenmann, C. H., A. Henn \& C. Wilson 1914. New fishes from Western Colombia, Ecuador, and Peru. Indiana University Studies, no. 19: 1-15.

Eigenmann, C. H. \& F. Ogle. 1907. An annotated list of characin fishes in the United States National Museum and the museum of Indiana University with description of new species. Proceedings of the United States National Museum, 33: 1-36.

Evers, H. G. \& I. Seidel. 2002. Wels atlas. Volume 1. Melle, Germany: Mergus, Verlag GmbH für Natur- und Heimtirekunde. 860 p.

Fernández-Yépez, A. 1972a. El genero Hemicetopsis Bleeker, 1863 (Cetopsidae) en Venezuela. Lagena, Instituto Oceanografico, Universidad de Oriente, no 30: 19-21.

Fernández-Yépez, A. 1972b. Análisis ictiológico del complejo hidrográfico (04) "río Yaracuy. "Venezuela: Dirección de Obras Hidráulicas, Ministerio de Obras Públicas. 25 p., 41 pls.

Ferraris, C. J., Jr. 1996. Denticetopsis, a new genus of South American whale catfish (Siluriformes: Cetopsidae, Cetopsinae), with two new species. Proceedings of the California Academy of Sciences, 49(6): 161-170.

Ferraris, C. J., Jr. \& B. A. Brown. 1991. A new species of Pseudocetopsis from the río Negro drainage of Venezuela (Siluriformes: Cetopsidae). Copeia, 1991(1): 161-165.

Ferraris, C. J., Jr. \& R. P. Vari. 1992. Catalog of type specimens of Recent fishes in the National Museum of Natural History, Smithsonian Institution, 4: Gonorynchiformes, Gymnotiformes, and Siluriformes (Teleostei: Ostariophysi). Smithsonian Contributions to Zoology, 535: 1-52.

Ferreira, E. 1995. Composição, distribuição e aspectos ecológicos da ictiofauna de um trecho do rio Trombetas, na área de influência da futura UHE Cachoeira Porteira, Estado do Pará, Brasil. Acta Amazonica, 23(1-4, Suplemento): 1-88. [issue for 1993, actual publication date 1995]

Ferreira, E., G. M. dos Santos \& M. Jégu. 1988. Aspectos ecológicos da ictiofauna do rio Macujaí, na área da ilha Paredão, Roraima, Brasil. Amazoniana, 10(3): 339-352.

Fowler, H. W. 1915. Notes on nematognathous fishes. Proceedings of the Academy of Natural Sciences of Philadelphia, 67: 203-243.

Fowler, H. W. 1940a. A collection of fishes obtained by Mr. William C. Morrow in the Ucayali River basin, Peru. Proceedings of the Academy of Natural Sciences of Philadelphia, 91[for 1939]: 219-289.

Fowler, H. W. 1940b. Zoological results of the second Bolivian expedition for the Academy of Natural Sciences of Philadelphia, 1936-1937. Part I. - the fishes. Proceedings of the Academy of Natural Sciences of Philadelphia, 92: 43-103.

Fowler, H. W. 1941. Los peces del Perú(Continuacion). Boletin del Museo de Historia Natural “Javier Prado,"Lima, 5(19): 466-487.
Fowler, H. W. 1942. Lista de peces de Colombia. Revista de la Academia Colombiana de Ciencias exactas, fisicas y naturales, 5 (17): 128-138.

Fowler, H. W. 1943. A collection of fresh-water fishes from Colombia, obtained chiefly by Brother Nicéforo Maria. Proceedings of the Academy of Natural Sciences of Philadelphia, 95: 223-266.

Fowler, H. W. 1944. Fresh-water fishes from northwestern Colombia. Proceedings of the Academy of Natural Sciences of Philadelphia, 96: 227-248.

Fowler, H. W. 1945. Los peces del Perú. Catálogo Sistematico de los peces que habitan en aguas peruanas. Lima: Museo de Historia Natural “Javier Prado". 298 p.

Fowler, H. W. 1954. Os peixes de água doce do Brasil (4. ${ }^{a}$ entrega). Arquivos de Zoologia do Estado do São Paulo, 9: $1-400$.

Galvis, G., J. I. Mojica \& M. Camargo. 1997. Peces del Catatumbo. Santafé de Bogotá, Colombia: Asociación Cravo Norte. $118 \mathrm{p}$.

Gill, T. N. 1870. On some new species of fishes obtained by Prof. Orton from the Maranon, or Upper Amazon, and Napo Rivers. Proceedings of the Academy of Natural Sciences of Philadelphia, 22: 92-96.

Goeldi, E. A. 1898. Primeira contribuição para o conhecimento does peixes do valle do Amazonas e das Guyanas. Boletim do Museu Paraense de Historia Natural e Ethnographia, 2(1-4): 443-488, 1 pl.

Gómez, S. E. \& J. C. Chebez. 1996. Peces de la provincia de Misiones. In: J. C. Chebez, (Ed.), Fauna Misionera, Pp. 3970. Buenos Aires: Editorial Literature of Latin America.

Gosline, W. A. 1945. Catálogo dos nematognatos de águadoce da América do Sul e Central. Boletim do Museu Nacional, new series, 33: 1-138.

Goulding, M. 1980. The fishes and the forest. Explorations in Amazonian natural history. Berkeley: University of California Press. 280 p.

Goulding, M. 1981. Man and fisheries on an Amazon frontier. The Hague: W. Junk Publishers. 137 p.

Goulding, M. 1989. Amazon. The flooded forest. London: BBC Books. 208 p.

Goulding, M., M. Leal Carvalho \& E. G. Ferreira. 1988. Rio Negro, rich life in poor water. Amazonian diversity and foodchain ecology as seen through fish communities. The Hague: SPB Academic Publishing. 200 p.

Günther, A. 1864. Catalogue of the fishes in the British $\mathrm{Mu}-$ seum. Catalogue of the Physostomi, containing the families Siluridae, Characinidae, Haplochitonidae, Sternoptychidae, Scopelidae, Stomiatidae in the collection of the British Museum. Volume 5. London: Trustees, British Museum. xxii $+455 \mathrm{p}$.

Henn, A. W. 1928. List of types of fishes in the collection of the Carnegie Museum on September 1, 1928. Annals of Carnegie Museum, 19(4): 51-99.

Ibarra, M. \& D. J. Stewart. 1987. Catalogue of type specimens of Recent fishes in Field Museum of Natural History. Fieldiana, Zoology, new series, 35(1377): 1-112. 
Ibarra, M. \& D. J. Stewart. 1989. Longitudinal zonation of sandy beach fishes in the Napo River basin, eastern Ecuador. Copeia, 1989 (2): 364-381.

International Commission on Zoological Nomenclature. 1999. International Code of Zoological Nomenclature. London: International Trust on Zoological Nomenclature. 306 p.

Kner, R. 1857. Ichthyologische Beiträge. II. Abtheilung. Sitzungsberichte der Akademie der Wissenschaften, Mathematische - Naturwissenschaftliche Klasse, Wien, 26 (373): 373-448, pls. 1-9.

Kottelat, M. 1984. Catalogue des types du Musée d'Histoire Naturelle de Neuchâtel. I. Pisces. Bulletin de la Société neuchâteloise des Sciences naturelles, 107: 143-153.

Kottelat, M. 1988. Authorship, dates of publication, status and types of Spix and Agassiz's Brazilian fishes. Spixiana, 11 (1): 69-93.

Kullander, S. O. 1986. Cichlid fishes of the Amazon drainage of Peru. Stockholm: Swedish Museum of Natural History. 431 p.

La Marca, E. (Editor). 1997. Vertebrados Actuales y Fósiles de Venezuela. Merida, Venezuela: Museo de Ciencia y Tecnologia de Mérida. 298 p.

Lasso, C. A. 1992. Composicion y aspectos ecologicos de la ictiofauna del bajo río Suapare, Serrania de los Pijiguaos (Escudo de Guayana), Venezuela. Memoria, Sociedad de Ciencias Naturales La Salle, 52(138): 5-56.

Lasso, C. A. \& J. Castroviejo. 1991. Composition, abundance and biomass of the benthic fish fauna from the Guaritico River of a Venezuelan flood plain. Annals of Limnology, 28(1):71-84.

Lasso, C. A., A. Machado-Allison \& R. Pérez Hernández. 1990. Consideraciones zoogeograficas de los peces de la Gran Sabana (Alto Caroni) Venezuela, y sus relaciones con las cuencas vecinas. Memoria, Sociedad de Ciencias Naturales, 50: 109-129.

Lasso, C. A., J. C. Señaris, O. Lasso \& J. Castroviejo. 1995. Aspectos ecologicos de una comunidad de bagres (Pisces: Siluroidei) en los llanos inundables de Venezuela. Acta Biologica Venezuelica, 16(1): 1-31.

Lauzanne, L., G. Loubens \& B. Le Guennec. 1991. Liste commentée des poissons de l'Amazonie bolivienne. Revue de Hydrobiologie Tropicale, 24(1): 61-76.

LeBail., P.-Y., P. Keith \& P. Planquette. 2000. Atlas des poissons d'eau douce de Guyane. Tome 2. Fascicule II. Siluriformes. Paris: Muséum National d'Histoire Naturelle, Service du Patronomie Naturel, and Institut d'Écologie et de Gestion de la Biodiversité. 307 p.

Lichtenstein, M. H. C. 1819. Ueber einige neue Arten con Fishen aus der Gattung Silurus. Zoologisches Magazin (Wiedemann), 1(3): 57-63.

Lichtenstein, M. H. C. 1823. Verzeihniss der Doubletten des zoologischen Museums der Königlichen Universität zu Berlin, nebst Beschreibung vieler bisher unbekkanter Arten von Säugethieren, Vögeln, Amphibien und Fischen, herausgegeben von Dr. H. Lichtenstein. Berlin: In Commission bei Trutwein. $\mathrm{x}+118 \mathrm{p}$.

López, H. L., A. M. Miquelarena, R. C. Menni \& J. R. Casciotta.
1984. Nuevas localidades para peces de agua dulce de la Republica Argentina. V(1). Historia Natural, Corrientes, 4(9): 81-90.

López, H. L., A. M. Miquelarena \& R. C. Menni. 2003. Lista comentada de los peces continentales de la Argentina. ProBiotA, Serie Técnica y Didática, no. 5: 1-87.

Lowe-McConnell, R. H. 1991. Natural history of fishes in Araguaia and Xingu Amazonian tributaries, Serra do Roncador, Mato Grosso, Brazil. Ichthyological Exploration of Freshwaters, 2(1): 63-82.

Lundberg, J. G. \& L. Rapp Py-Daniel. 1994. Bathycetopsis oliveirai, gen. et sp. nov., a blind and depigmented catfish (Siluriformes: Cetopsidae) from the Brazilian Amazon. Copeia, 1994(2): 381-390.

Machado-Allison, A., C. Lasso \& R. Royero-León. 1993. Inventario preliminar y aspectos ecologicos de los peces de los ríos Aguaro y Guariquito (Parque Nacional), Estado Guarico, Venezuela. Memoria Sociedad de Ciencias Naturales La Salle, 53(139): 55-80.

Machado-Allison, A., B. Chernoff, R. Royero-León, F. MagoLeccia, J. Velázquez, C. Lasso, H. López-Rojas, A. BonillaRivero, F. Provenzano \& C. Silvera. 2000. Ictiofauna de la cuenca del río Cuyuni en Venezuela. Intercencia, 25(1): 13-21.

Machado-Allison, A., B. Chernoff, F. Provenzano, P. W. Willink, A. Marcano, P. Petry, T. Jones \& B. Sidlauskis. 2003. Fishes collected during the AquaRAP expedition to the Caura River basin, Bolívar State, Venezuela. Appendix 8, Pp. 267-275. In: B. Chernoff, A. Machado-Allison. K. Riseng \& J. R. Montambault, (Eds.), A biological assessment of the aquatic ecosystems of the Caura River basin, Bolívar State, Venezuela. Washington, D. C.: Conservation International.

Machado-Allison, A., F. Mago-Leccia, O. Castillo, R. Royero, C. Marrero, C. Lasso \& F. Provenzano. 1993. Lista de especies de peces reportadas en los diferentes cuerpos de agua de los bajos Llanos de Venezuela, Pp. 129-136. In: A. Machado-Allison, (Ed.), Los peces de los Llanos de Venezuela: un ensayo sobre su historia natural. $2^{\text {nd }}$ Edition. Caracas: Universidad Central de Venezuela.

Machado-Allison, A. \& H. Moreno. 1993. Estudios sobre la comunidad de peces del río Orituco, Estado Guarico, Venezuela. Parte I. Inventario, abundancia relativa y diversidad. Acta Biologica Venezuelica, 14(4): 77-94.

Magalhães, A. C. de. 1931. Monographia Brazileira de Peixes Fluvias. São Paulo: Graphicars. 269 p.

Mago-Leccia, F. 1967. Notas preliminares sobre los peces de los Llanos de Venezuela. Boletin Sociedad Venezolana de Ciencias Naturales, Caracas, 27(112): 237-263.

Mago-Leccia, F. 1970. Lista de los peces de Venezuela. Caracas: Ministerio de Agricultura y Cria. 241 p.

Mendes dos Santos, G., M. Jegú \& B. de Merona. 1984. Catálogo de peixes comerciais do baixo rio Tocantins. Manaus, Brazil: Contrais Eletricas do Norte do Brasil, S. A. (Electronorte), Choselho Nacional de Desenvolvimento Científico e Tecnológico (CNPq), and Instituto Nacional de Perquisas da Amazonia (INPA). 83 p. 
Milani de Arnal, M. 1991. Osteologia del barge ciego Cetopsis coecutiens (Lichtenstein) 1819 (Siluriformes, Cetopsidae) y especies de la familia Cetopsidae presentes en Venezuela. Unpublished Licenciada thesis. Universidad Central de Venezuela. 191 p.

Miles, C. W. 1943. Estudio económico y ecológico de los peces de aqua dulce del Valle del Cauca. Bogotá: Secretaria de Agricultura y Fomento, Departamento del Valle del Cauca. 97 p.

Miles, C. W. 1947. Los peces del río Magdalena. Bogotá: Ministerio de la Economica Nacional. Seccion de Piscicultura, Pesca y Caza. $214+$ xxvii p.

Miles, C. W. 1973. Estudio económico y ecológico de los peces de aqua dulce del Valle del Cauca. Cespedesia, Cali, 2(5): 9-63.

Miranda-Ribeiro, A. 1912. Fauna Brasiliense. Peixes. IV(A). Eleutherobranchios Aspirophoros. Archivos do Museu Nacional, Rio de Janeiro, 16: 1-544 [date on title page 1911 but published 1912].

Miranda-Ribeiro, A. 1914. Pimelodidae, Trachycorystidae, Cetopsidae, Bunocephalidae, Auchenipteridae, e Hypophthalmidae. Commissão de Linhas Telegraphicas Estrategicas de Matto-Grosso ao Amazonas. Annexo no. 5. Historia Natural, Zoologia, no. 15: 1-13, 2 pls.

Miranda-Ribeiro, A. 1918. Lista dos peixes Brasileiros do Museu Paulista (1 ${ }^{\mathrm{a}}$ parte). Revista do Museu Paulista, São Paulo, 10: 707-736.

Miranda-Ribeiro, A. 1920. Peixes (exclusive Characinidae). Commissão de Linhas Telegraphicas Estrategicas de Matto-Grosso ao Amazonas. Annexo no. 5. Historia Natural, Zoologia, No. 58: 1-16.

Mojica-C., J. I. 1999. Lista preliminar de las especies de peces dulceacuícolas de Colombia. Revista de la Academia Colombiana de Ciencias Exactas, Físicas y Naturales, Suplemento Especial, 23: 547-566.

Mol, J. H., D. Resida, J. C. Ramlal \& C. R. Becker. 2000. Effects of El Niño-related drought on freshwater and brackishwater fishes in Suriname, South America. Environmental Biology of Fishes, 59(4): 429-440.

Nakatani, K., A. A. Agostinho, G. Baumgartner, A. Bialetzki, P. V. Sanches, M. C. Makrakis \& C. S. Pavanelli. 2001. Ovos e larvas de peixes de água doce. Desenvolvimento e manual de identificação. Maringá, Brazil: Editora da Universidade Estadual de Maringá. 378 p.

Norman, J. R. 1926. A new catfish of the genus Cetopsis from the rio das Velhas, Brazil. Annals and Magazine of Natural History, series 9, 17: 116.

Oliveros, O. B. \& L. M. Rossi. 1992. Nuevo hallazgo de Pseudocetopsis gobioides (Kner, 1857) para las Republica Argentina (Pisces: Cetopsidae). Revista de la Asociación de Ciencias Naturales del Litoral, 23(1-2): 77-81.

Oliveira, J. C. de. 1988. Osteologia e revisão sistemática de Cetopsidae (Teleostei, Siluriformes). Unpublished Ph. D. Dissertation, Universidade de São Paulo, 241 p.

Oliveira, J. C. de, R. P. Vari \& C. J. Ferraris, Jr. 2001. A new species of "whale catfish" (Siluriformes, Cetopsidae) from the western portions of the Amazon basin. Proceedings of the Biological Society of Washington, 114(3): 574-578.

Orcés, G. 1967. Sobre algunos peces colectados en el sistema del río Santiago, Ecuador Occidental. Politecnia, Organo Oficial de la Escuela Politecnia Nacional, 1(1): 137-143.

Ortega, H. 1996. Ictiofauna del Parque Nacional Manu, Perú. In: D.C. Wilson \& A. Sandoval (Eds.). Manu, The biodiversity of southeastern Peru, Pp. 453-482. Washington, D. C.: Smithsonian Institution Press.

Ortega, H. \& R. P. Vari. 1986. Annotated checklist of the freshwater fishes of Peru. Smithsonian Contributions to Zoology, 437: 1-25.

Ovchynnyk, M. M. 1967. Freshwater fishes of Ecuador. Latin American Studies Center, Michigan State University, Monograph Series, 1: 1-44.

Ovchynnyk, M. M. 1968. Annotated list of the freshwater fish of Ecuador. Zoologischer Anzeiger, 181: 237-268.

Pavanelli, C. S. \& É. P. Caramaschi. 1997. Composition of the ichthyofauna of two small tributaries of the Paraná River, Porto Rico, Paraná State, Brazil. Ichthyological Exploration of Freshwaters, 8(1): 23-31.

Pearson, N. E. 1924. The fishes of the eastern slope of the Andes, I: The fishes of the Rio Beni basin collected by the Mulford expedition. Indiana University Studies, 11(64): 1-83.

Pearson, N. E. 1937a. The fishes of the Atlantic and Pacific slopes near Cajamarca, Peru. Proceedings of the California Academy of Sciences, series 4, 23(7): 87-98.

Pearson, N. E. 1937b. The fishes of the Beni-Mamoré and Paraguay basins, and a discussion of the Paraguayan fauna. Proceedings of the California Academy of Sciences, series 4, 23(8): 99-114.

Péfaur, J. E. 1988. Catalogacion economica de la ictiofauna alto-andina Venezolana. Memoria, Sociedad de Ciencias Naturales La Salle, 48(Suppl.): 471-493.

Pellegrin, J. 1899. Note sur les poissons recueillis par M. F. Geay dans l'Apuré et ses affluents. Bulletin du Museum National d'Histoire Naturelle, Paris, 5: 156-159.

Perugia, A. 1897. Di alcuni pesci raccolti in Bolivia dal Prof. Luigi Balzan. Annali del Museo Civico di Storia Naturale Giacomo Doria, Genova, series 2, 8: 16-27.

Pinna, M. C. C. de. 1998. Phylogenetic relationships of Neotropical Siluriformes (Teleostei: Ostariophysi): Historical overview and synthesis of hypotheses, Pp. 279-330. In: L. R. Malabarba, R. E. Reis, R. P. Vari, A. M. . Lucena \& C. Lucena, (Eds.), Phylogeny and Classification of Neotropical Fishes. Porto Alegre, Brazil: Edipucrs.

de Pinna, M. C. C. de \& R. P. Vari. 1995. Monophyly and phylogenetic diagnosis of the family Cetopsidae, with synonymization of the Helogenidae (Teleostei: Siluriformes). Smithsonian Contributions to Zoology, 51: i-iii+1-26.

Ponton, D. \& G. H. Copp. 1997. Early dry-season community structure and habitat use of young fish in tributaries of the River Sinnamary (French Guiana, South America) before and after hydrodam operation. Environmental Biology of Fishes, 50: 225-256.

Pozzi, A. J. 1945. Sistematica y distribution de los peces de 
agua dulce de la Republica Argentina. Gaea, 7(2): 239-292.

Provenzano, F., A. Marcano \& P. Mondaca. 1998. Catalago de ejemplares tipos en la coleccion de peces del Museo de Biologica de la Universidad Central de Venezuela. Acta Biologica Venezuelica, 18(1): 1-24.

Regan, C. T. 1905. [Sketches of fishes of the Rio Negro]. Proceedings of the Zoological Society of London, 1: 189-190.

Ringuelet, R. A. 1975. Zoogeografía y ecología de los peces de aguas continentales de la Argentina y consideraciones sobre las áreas ictiológicas de América del Sur. Ecosur, 2(3): 1-122.

Ringuelet, R. A. \& R. H. Arámburu. 1961. Peces Argentinos de agua dulce. Agro, 3(7): 1-98.

Ringuelet, R. A., R. H. Arámburu \& A. Alonso de Arámburu. 1967. Los peces Argentinos de agua dulce. La Plata, Argentina: Comision de Investigación Científica. 602 p.

Roman, B. 1982. Colleción: Los peces de los Llanos de Venezuela. II. Los Bagres. Caracas: Fundacion Cientifica Fluvial de los Llanos. 189 p.

Roman-Valencia, C. 1990. Lista y distribucion de peces en la cuenca media del río Atrato, Choco, Colombia. Caldasia, 16(77): 201-208.

Sato, Y. \& H. P. Godinho. 1999. Peixes da bacia do rio São Francisco. Chapter 17, Pp. 401-413. In: R. H. LoweMcConnell. Estudos ecológicos de comunidades de peixes peixes tropicais. São Paulo, Brazil: Editora de Universidade de São Paulo.

Saul, W. G. 1975. An ecological study of fishes at a site in upper Amazonian Ecuador. Proceedings of the Academy of Natural Sciences of Philadelphia, 127(12): 93-134.

Schultz, H. 1961. Blue-eyed Indian - a city boy's sojourn with primitive tribesman in Brazil. National Geographic, 120(1): 64-89.

Schultz, L. P. 1944. The catfishes of Venezuela, with descriptions of thirty-eight new forms. Proceedings of the United States National Museum, 94 (3172): 173-338, pls. 1-14.

Silvano, R. A. M., O. T. Oyakawa, B. D. do Amaral \& A. Begossi. 2001. Peixes do Alto rio Juruá (Amazonas, Brasil). São Paulo, Brazil: Editora da Universidade de São Paulo. $298 \mathrm{p}$.

Spix, J. B. von \& L. Agassiz. 1829-31. Selecta genera et species piscium quos in itinere per Brasiliam annos MDCCCXVIIMDCCCXX jussu et auspiciis Maximiliani Josephi I. . . . colleget et pingendso curavit Dr J. B. de Spix. ... Monachii. Part 1: i-xvi+i-ii+82, pls. 1-48; Part 2: 83-138, pls. 49-101.

Starks, E. C. 1913. The fishes of the Stanford Expedition to Brazil. Leland Stanford Junior University Publications, University Series, 1-77, 15 pls.

Steindachner, F. 1880. Zur Fisch-Fauna des Cauca und der Flüsse bei Guayaquil. Denkschriften der Akademie der Wissenschaften, Wien, 42: 55-104, pls. 1-9.

Steindachner, F. 1882. Beiträge zur Kenntniss der Flussfische Südamerikas (IV). Anzeiger der Akademie der Wissenschaften, Wien, 19(19): 175-180.

Steindachner, F. 1883. Beiträge zur Kenntniss der Flussfische Südamerikas. IV. Denkschriften der Akademie der Wissenschaften, Wien, 46: 1-44, pls. 1-7.

Steindachner, F. 1902. Herpetologische und ichthyologische
Ergebnisse einer Reise nach Südamerika, mit einer Einleitung con Therese Prinzessin von Bayern. Denkschriften der Akademie der Wissenschaften, Wien, 72: 89-148.

Stewart, D., R. Barriga \& M. Ibarra. 1987. Ictiofauna de la cuenca del río Napo, Ecuador Oriental: Lista anotada de especies. Politecnica, Revista de Información TécnicoCientífica, Biologia, 12(4): 9-63.

Swainson, W. 1839. The natural history and classification of fishes, amphibians \& reptiles, or Monocardian animals. Volume 2. London: Longman, Orme, Brown, Green, and Longman. 448 p.

Taphorn, D. C. \& J. G. García Tenía. 1991. El río Claro y sus peces, con consideraciones de los impactos ambientales de las presas sobre la ictiofauna del bajo río Caroni. Biollania, 8: 23-45.

Taphorn, D. C., R. Royero, A. Machado-Allison \& F. MagoLeccia. 1997. Lista actualizada de los peces de agua dulce de Venezuela, Pp. 55-100. In: E. La Marca, (Ed.), Vertebratos actuales y fósiles de Venezuela. Serie Catálogo Zoológico de Venezuela. Volume 1. Merida, Venezuela: Museo de Ciencia y Tecnología de Mérida.

Terrazas-Urquidi, W. T. 1970. Lista de peces Bolivianos. Publicacion, Academia de Ciencias de Bolivia, 24: 1-65.

Tortonese, E. 1940. Elenco dei tipi esistenti nella collezione ittiologica del R. Museo di Torino. Bolletino dei Musei di Zoologia e di Anatomia Comparata della Universita di Torino, series 3, 48(111): 133-144.

Travassos, H. 1960. Catálogo dos peixes do vale do rio São Francisco. Boletim do Sociedad Cearana do Agronomia, 1(1): 1-66.

Van der Stigchel, J. W. B. 1947. The South American Nematognathi of the museums at Leiden and Amsterdam. Zoologische Mededeelingen, 27: 1-204.

Vari, R. P. 1989a. Systematics of the Neotropical characiform genus Psectrogaster Eigenmann and Eigenmann (Pisces: Characiformes). Smithsonian Contributions to Zoology, 481: 1-43.

Vari, R. P. 1989b. Systematics of the Neotropical characiform genus Pseudocurimata Fernández-Yépez(Pisces: Ostariophysi). Smithsonian Contributions to Zoology, 490: 1-28.

Vari, R. P. \& C. J. Ferraris, Jr. 2003. Family Cetopsidae, Pp. 257260. In: R. E. Reis, S. O. Kullander \& C. J. Ferraris, Jr., (Eds.), Check List of the Freshwater Fishes of South and Central America. Porto Alegre, Brazil: Edipucrs.

Vari, R. P., C. J. Ferraris, Jr. \& P. Keith. 2003. A new Pseudocetopsis species (Siluriformes: Cetopsidae) from Suriname and French Guiana. Proceedings of the Biological Society of Washington, 116(3): 692-698.

Vari, R. P. \& A. S. Harold. 2001. Phylogenetic study of the Neotropical fish genera Creagrutus Günther and Piabina Reinhardt (Teleostei: Ostariophysi: Characiformes), with a revision of the cis-Andean species. Smithsonian Contributions to Zoology, 613: 1-239.

Vari, R. P. \& H. Ortega. 1986. The catfishes of the Neotropical family Helogenidae (Ostariophysi: Siluroidei). Smithsonian Contributions to Zoology, 442: 1-20. 
Wallace, A. R. 2002. Peixes do Rio Negro. [Fishes of the Rio Negro]. Alfred Russel Wallace (1850-1852). Organization, Introductory Text and Translation by Mônica de ToledoPiza Ragazzo. São Paulo, Brazil: Editora de Universidade de São Paulo. 518 p.

Weber, C. 1998. Catalogue revise des types primaries de la collection icthyologique de Muséum d'Histoire Naturelle de la Ville de Genève (MHNG). Revue Suisee de Zoologie, 105(1):3-14.

Submitted December 2004

Accepted May 2005 